ROBERTO DE GOUVEIA E FREITAS JÚNIOR

\title{
LEGISLAÇÃO E OCUPAÇÃO URBANA EM LOTES PRIVADOS DO CENTRO DE SÃO PAULO NO SÉCULO XX
}


ROBERTO DE GOUVEIA E FREITAS JÚNIOR

\title{
LEGISLAÇÃO E OCUPAÇÃO URBANA EM LOTES PRIVADOS DO CENTRO DE SÃO PAULO NO SÉCULO XX
}

\author{
Dissertação apresentada à Escola \\ Politécnica da Universidade de São \\ Paulo para obtenção do título de \\ Mestre em Engenharia
}


ROBERTO DE GOUVEIA E FREITAS JÚNIOR

\section{LEGISLAÇÃO E OCUPAÇÃO URBANA EM LOTES PRIVADOS DO CENTRO DE SÃO PAULO NO SÉCULO XX}

Dissertação apresentada à Escola Politécnica da Universidade de São Paulo para obtenção do título de Mestre em Engenharia

Área de concentração: Engenharia Urbana, Infra-estrutura e Estruturação dos Espaços Urbanos

Orientador: Prof. Dr. Witold Zmitrowicz 
Freitas Júnior, Roberto de Gouveia e

Legislação e ocupação urbana em lotes privados do centro de São Paulo no século XX / R.G. e Freitas Júnior. - São Paulo, 2008.

227 p.

Dissertação (Mestrado) - Escola Politécnica da Universidade de São Paulo. Departamento de Engenharia de Construção Civil.

1. Legislação urbana - Século XX - São Paulo (SP) I. Universidade de São Paulo. Escola Politécnica. Departamento de Engenharia de Construção Civil II. t. 
A minha querida Renata, pelo incentivo e apoio em todos os momentos da vida. 


\section{AGRADECIMENTOS}

Ao Prof. Dr. Witold Zmitrowicz, pela sábia orientação e constante estímulo à pesquisa e desenvolvimento deste trabalho.

Ao Prof. Dr. Nestor Goulart Reis Filho, pela contribuição e acompanhamento indispensáveis desde a graduação.

Ao Prof. Dr. Fernando Dias Menezes de Almeida, pelas precisas considerações e orientações a respeito deste trabalho.

Ao Prof. Dr. Paulo Julio Valentino Bruna pelo apoio constante ao longo de minha vida acadêmica e profissional.

Ao Prof. Dr. Antonio Marcos de Aguirra Massola e ao Prof. Dr. Luiz Sérgio Franco pelo apoio ao início de meu trabalho acadêmico na pós-graduação.

Ao Prof. Dr. Sylvio Barros Sawaya e ao Prof. Dr. Silvio Dworeck pelo apoio a esta pesquisa.

Ao Prof. Dr. Gian Carlo Gasperini, ao Prof. Roberto Cláudio dos Santos Aflalo Filho, a Luiz Felipe Aflalo Herman e a Carlos Fernando de Amaral Guimarães pelo apoio durante o desenvolvimento deste trabalho.

Aos meus pais, pelo exemplo de postura, pela dedicação e incentivo constante.

Aos meus irmãos, familiares e amigos, pela paciência e apoio durante esta etapa.

À Katia Cristina Fernandes pela revisão ortográfica.

A todos que contribuíram, direta ou indiretamente, para a realização deste trabalho em especial a Fátima Regina Gonçalves, Sarah Ferreira, Rosilene Lefone, Sidney Lanzarotto, Maria Iracema Silva Ferreira, Regina Taeko Katayama, José Tadeu de Azevedo Maia, Carla Bisquolo, Nanci Marques, Lucimara Mendonça, Fabiana das Dores, Junko Oura, Magali Simoni Guerra e Cátia Rocha Vicentini. 


\section{RESUMO}

No intuito de contribuir para o entendimento da paisagem edificada existente na cidade de São Paulo atualmente, considerando-se a inviabilidade de um estudo geral a respeito de todas as variáveis envolvidas no processo de criação desta paisagem, esta pesquisa enfoca especificamente a legislação paulistana, enquanto estrutura urbana, buscando discutir sua relevância na caracterização do espaço construído desta cidade.

Entendendo-se que a paisagem urbana reflete principalmente o conjunto de obras edificadas em lotes privados, visto que as obras construídas para fins ou uso públicos representam uma pequena parcela da região urbanizada, nesta pesquisa compara-se a legislação urbana paulistana às obras particulares construídas no período de sua vigência.

Sendo assim, parte-se de um recorte físico e temporal para analisarem-se as leis, enquanto fatos, e evidenciarem-se suas decorrências no espaço urbano paulistano. Para isso, foi definido um perímetro de estudo dentro da cidade de São Paulo - os atuais distritos Sé e República - sobre o qual foram aplicadas as leis urbanas durante um período específico, o século $X X$, de modo a verificar se os reflexos da aplicação desta legislação correspondem ou não à interpretação gráfica elaborada com base nas leis estudadas neste trabalho. 


\begin{abstract}
With the intent of contributing to the understanding of the existing built landscape in the city of São Paulo, considering the impossibility of a general study that would cover all factors involved in the process of creating this landscape, this research focuses specifically on São Paulo legislation, in the sense of urban structure, aiming to discuss its relevance in the characterization of built areas in this city.

Understanding that the urban landscape mainly reflects the group of buildings in private lots of land, considering that public constructions represent only a small portion of the urban area, this research presents a comparison of São Paulo urban legislation and the private constructions that were built in the period of time the law was in force.

This way, this study looks at a specific area during a specific period of time, to analyze the laws, in terms of facts, and make their consequences evident in the São Paulo urban space. In order to do that, a study perimeter was defined in the city - the present districts of Sé and República - upon which the $20^{\text {Th }}$ century urban laws were applied, to verify if the ramifications of the application of this legislation correspond or not to the graphic interpretation that was developed based on the laws studied here.
\end{abstract}




\section{SUMÁRIO}

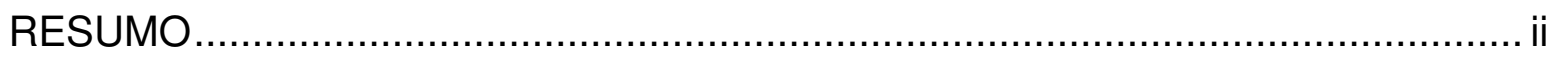

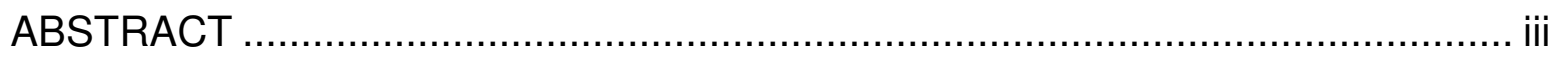

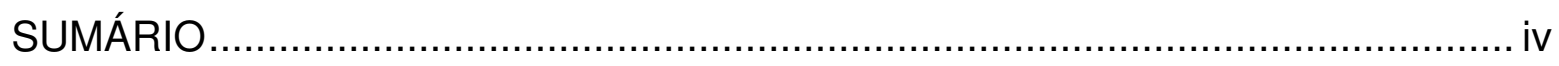

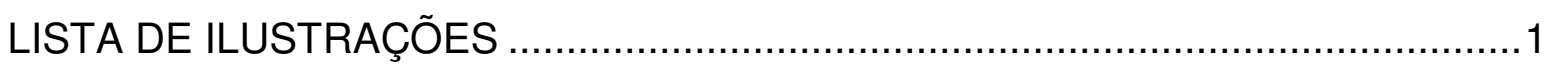

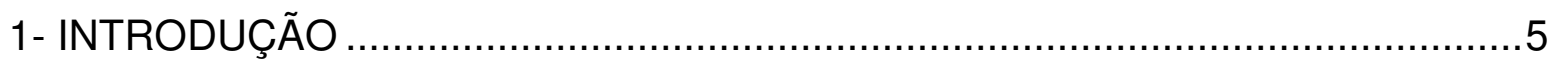

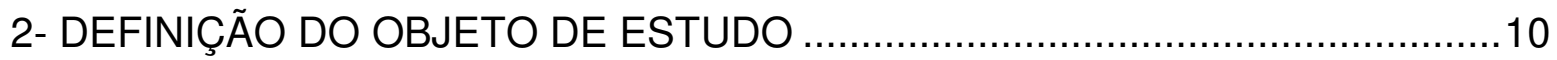

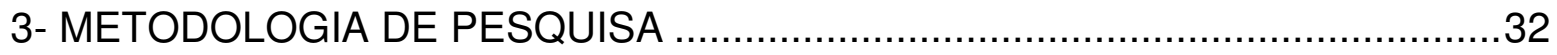

4- AS LEIS E O CENTRO DA CIDADE DE SÃO PAULO ................................37

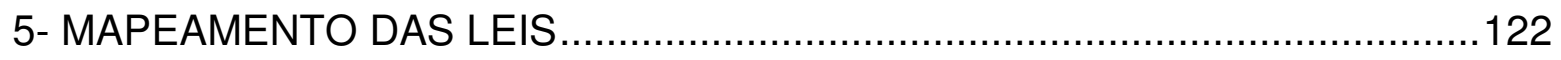

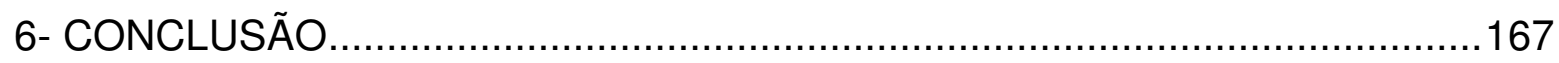

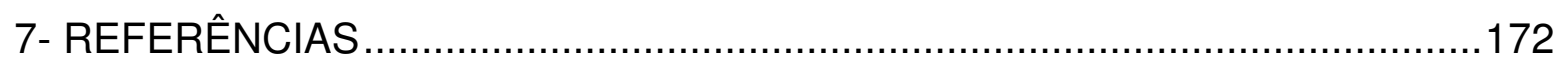

ANEXO 1 - CONSTRUÇÕES NO PERÍMETRO DE ESTUDO ...........................191

ANEXO 2 - CATEGORIAS DE USO E OCUPAÇÃO DO SOLO .........................223

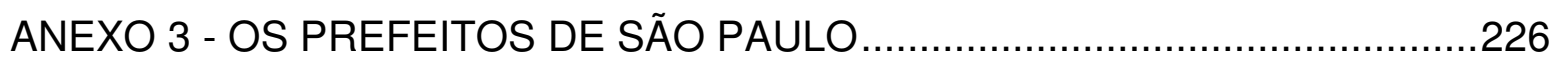




\section{LISTA DE ILUSTRAÇÕES}

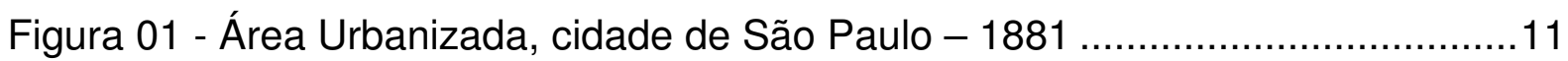

Figura 02 - 1893 - Região central de São Paulo ....................................................12

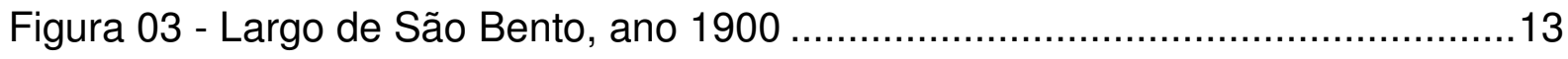

Figura 04 - Estação da Luz, ano 1902 .....................................................13

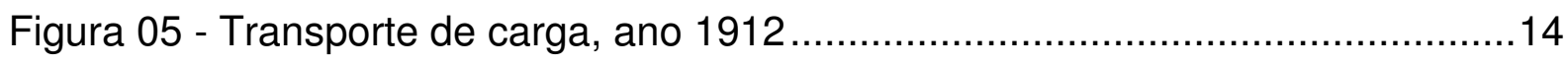

Figura 06 - Área Urbanizada, cidade de São Paulo - 1882/1914 ..........................15

Figura 07 - Transporte de operários em bondes elétricos, 1916 ..........................16

Figura 08 - Trânsito de animais X Transporte a tração mecânica, 1916 ..................16

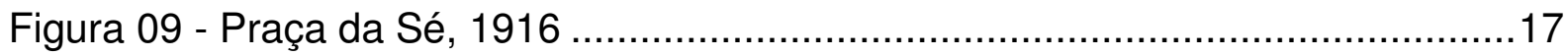

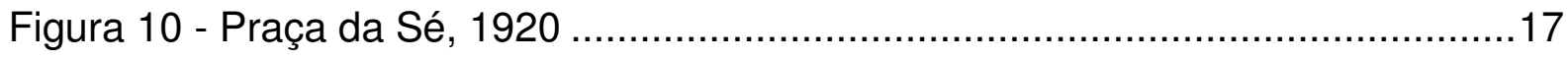

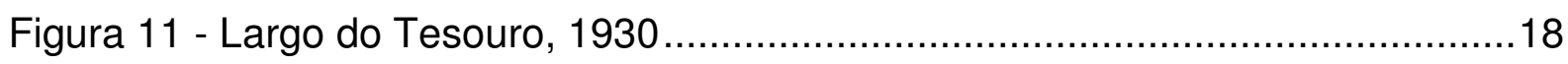

Figura 12 - Área Urbanizada, cidade de São Paulo - 1915/1929 .............................18

Figura 13 - Largo de São Bento, 1930 ........................................................ 19

Figura 14 - Avenida de Irradiação, 1a. versão, J. F. Ulhôa Cintra ...........................20

Figura 15 - Avenida de Irradiação, $2^{\mathrm{a}}$. versão .............................................21

Figura 16 - Planta Geral dos Melhoramentos Centrais (1945), F. Prestes Maia .......22

Figura 17 - Modelo urbano presente em estudos para São Paulo ..........................24

Figura 18 - Proposta para a Porta do Brasil .....................................................25

Figura 19 - Vale do Anhangabaú - O Parque .................................................25

Figura 20 - Esquema teórico de São Paulo, em formas geométricas .....................26

Figura 21 - Caracterização do centro da cidade de São Paulo ...............................29

Figura 22 - Área Urbanizada, cidade de São Paulo - até 1974 ...............................30

Figura 23 - Perímetro de estudo: "centro" da cidade de São Paulo .........................33

Figura 24 - Código de Posturas do Município de São Paulo 06/10/1886 .................42

Figura 25 - Código Sanitário do Estado de São Paulo 02/03/1894 .........................45

Figura 26 - Código Sanitário do Estado de São Paulo 02/03/1894 ........................46

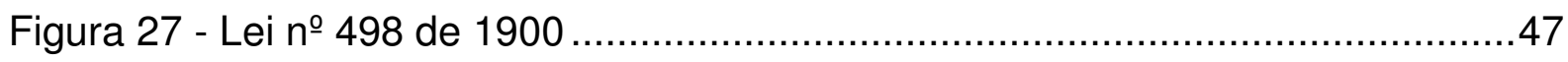

Figura 28 - Perímetro urbano no Município de São Paulo em 1900........................48

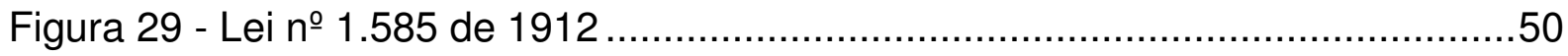

Figura 30 - Perímetros do Município de São Paulo em 1914, Lei nํ 1.788/1914 _.....52

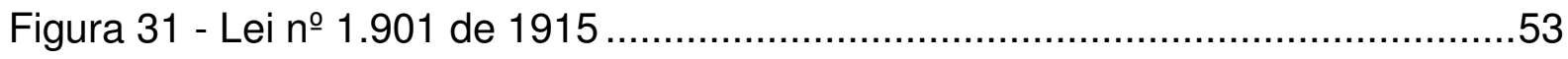


Figura 32 - Ato ํㅜ 900 de 1916 .54

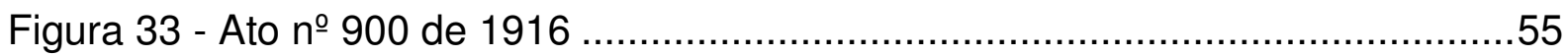

Figura 34 - Ato oㅜ 1.235 de 1918 incorporou Lei Estadual oㅜ 1.596/17 .......................59

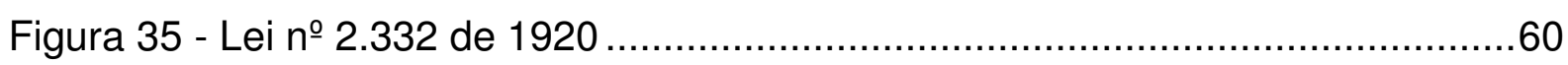

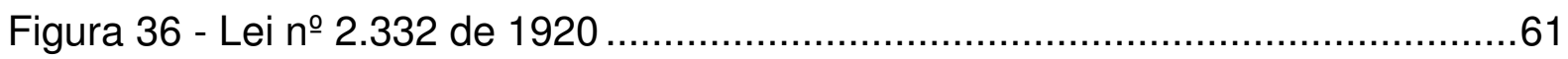

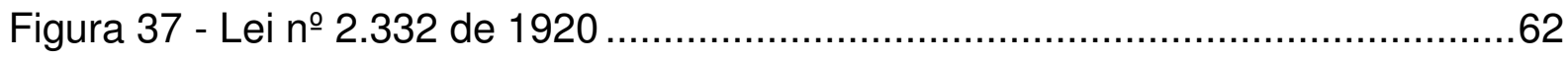

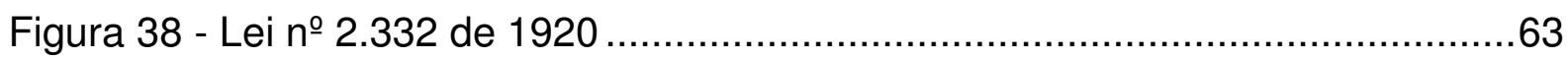

Figura 39 - Divisão do município de São Paulo: Lei o 1.874/15 ….........................64

Figura 40 - Modelo idealizado de cidade, refletido nas leis paulistanas...................66

Figura 41 - Novos modelos de cidade surgiam no início do século XX ....................68

Figura 42 - Divisão do Município de São Paulo: Lei no 3.427 de 1929......................70

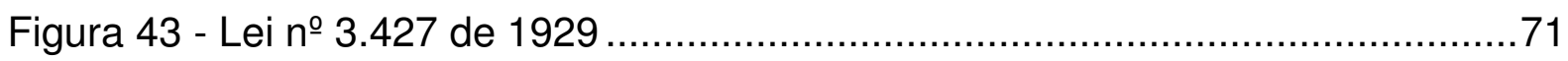

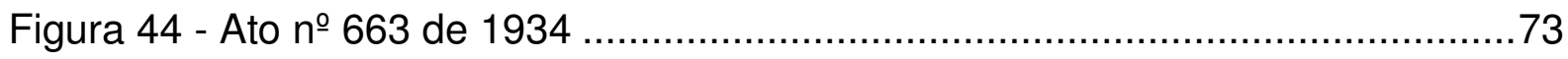

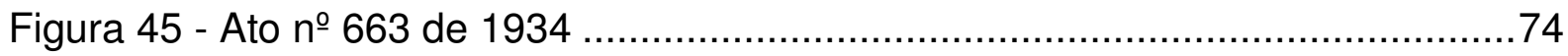

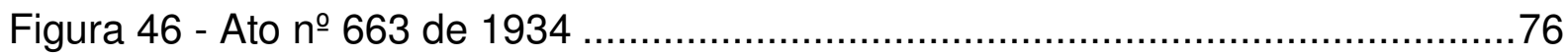

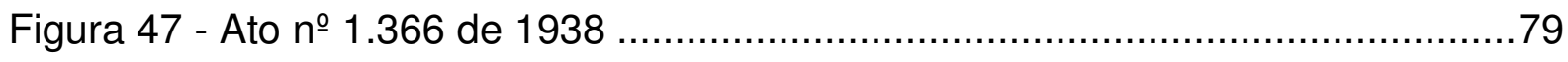

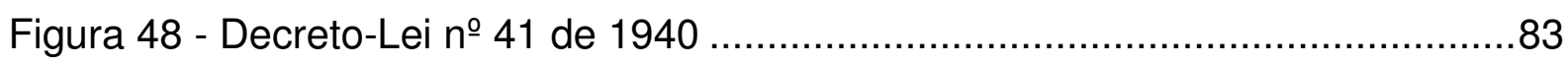

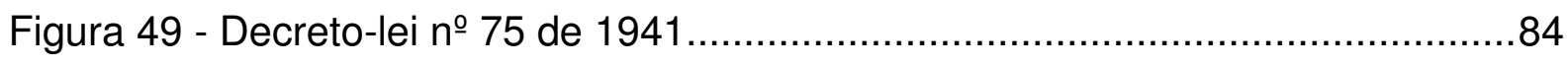

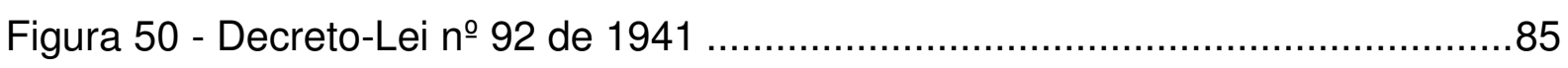

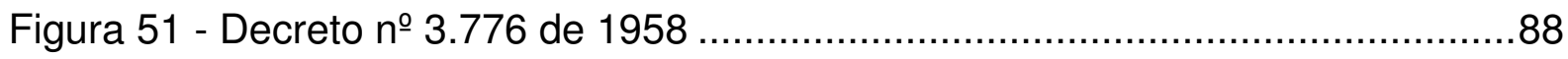

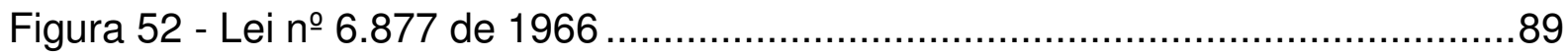

Figura 53 - Zoneamento na área em estudo: 1972 ...........................................93

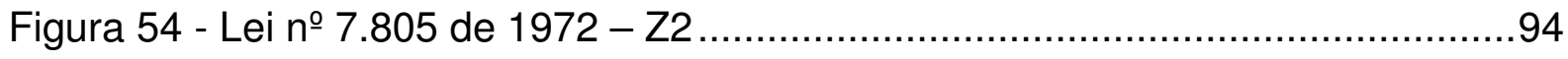

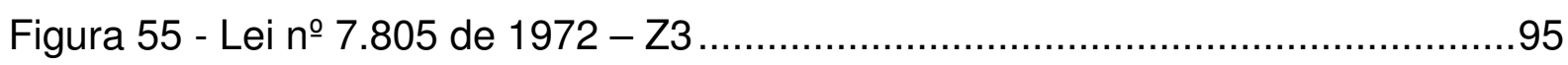

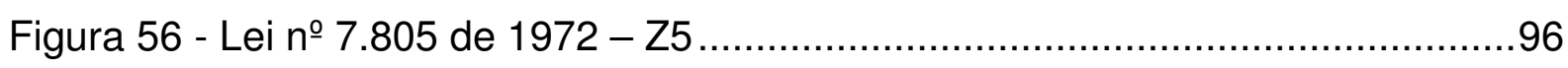

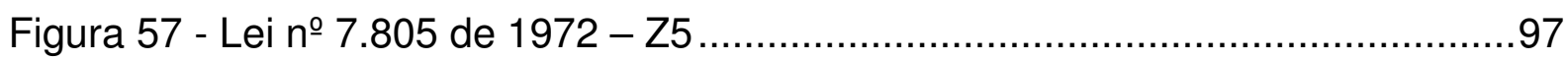

Figura 58 - 1893 - Trecho da região central de São Paulo ...................................101

Figura 59 - Lei no 8.266 de 1975 - Código de Edificações......................................102

Figura 60 - Lei no 8.266 de 1975 - Código de Edificações.....................................103

Figura 61 - Lei no 8.266 de 1975 - Código de Edificações.....................................104

Figura 62 - Lei ํo 8.266 de 1975 - Código de Edificações......................................105

Figura 63 - Lei no 8.266 de 1975 - Código de Edificações......................................106

Figura 64 - Lei no 8.266 de 1975 - Código de Edificações......................................107

Figura 65 - Lei oํ 8.266 de 1975 - Código de Edificações......................................108 
Figura 66 - Lei no 8.266 de 1975 - Código de Edificações......................................109

Figura 67 - Lei no 8.266 de 1975 - Código de Edificações....................................110

Figura 68 - Lei no 8.266 de 1975 - Código de Edificações.....................................111

Figura 69 - Lei no 8.266 de 1975 - Código de Edificações.....................................112

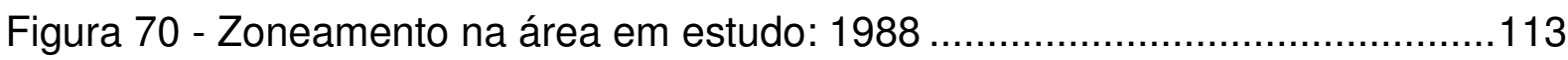

Figura 71 - Lei no 11.228 de 1992 - Novo Código de Obras e Edificações...............114

Figura 72 - Lei no 11.228 de 1992 - Novo Código de Obras e Edificações..............115

Figura 73 - Lei no 11.228 de 1992 - Novo Código de Obras e Edificações..............116

Figura 74 - Lei no 11.228 de 1992 - Novo Código de Obras e Edificações...............117

Figura 75 - Lei no 11.228 de 1992 - Novo Código de Obras e Edificações...............118

Figura 76 - Lei no 11.228 de 1992 - Novo Código de Obras e Edificações..............119

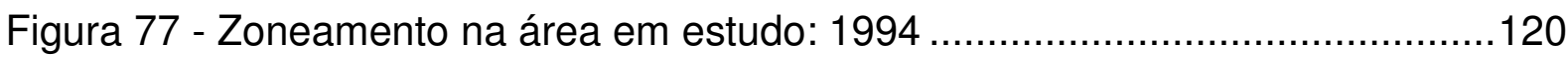

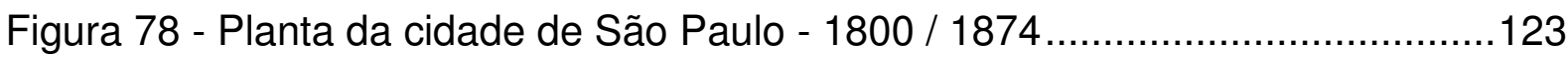

Figura 79 - Planta do centro de São Paulo, 1897 - leis de 1893 a 1904 ................125

Figura 80 - Rua Conselheiro Crispiniano ……….......................................127

Figura 81 - Rua Conselheiro Crispiniano …………….................................127

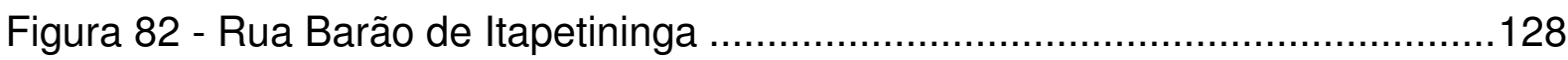

Figura 83 - Planta do centro de São Paulo, 1905 - leis de 1907 a 1912 ................130

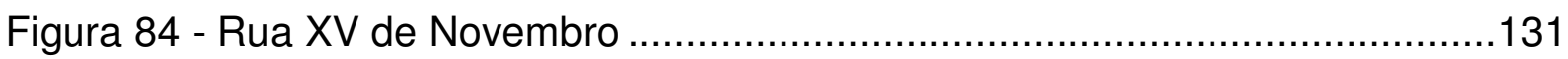

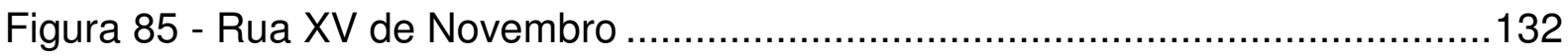

Figura 86 - Fundos da Rua XV de Novembro ................................................133

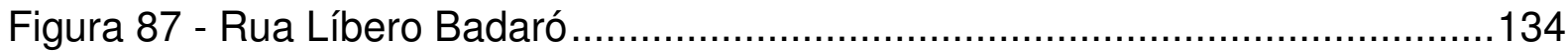

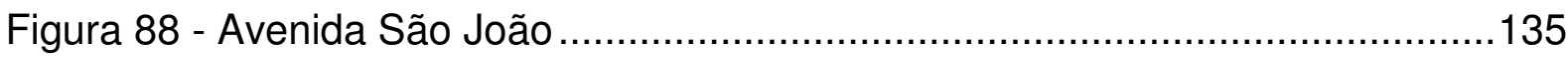

Figura 89 - Planta do centro de São Paulo, 1905 - leis de 1913 a 1916 .................136

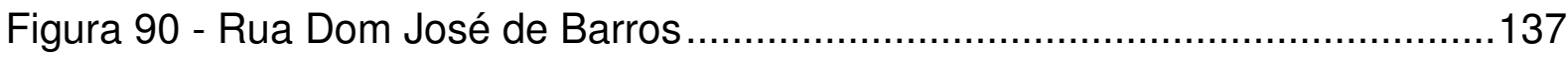

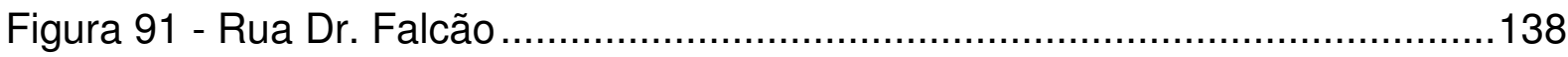

Figura 92 - Planta do centro de São Paulo, 1905 - leis de 1918 a 1923 .................139

Figura 93 - Rua Tabatinguera .............................................................................

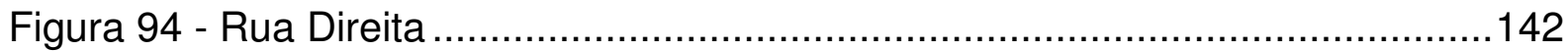

Figura 95 - Planta do centro de São Paulo, 1930 - leis de 1929 a 1935 ................143

Figura 96 - Avenida Duque de Caxias, com Avenida Rio Branco .........................146

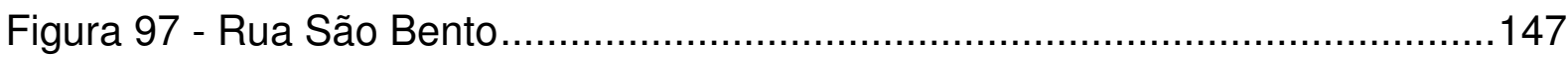

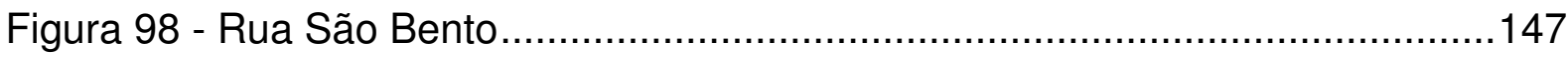

Figura 99 - Planta do centro de São Paulo, 1930 - leis de 1938 a 1940 ................148 


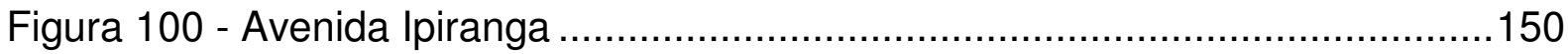

Figura 101 - Planta do centro de São Paulo, 1930 - leis de 1941 ..........................151

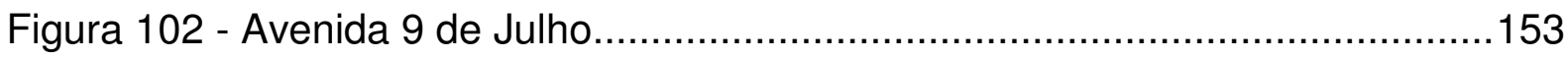

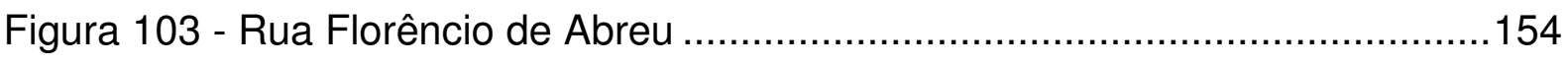

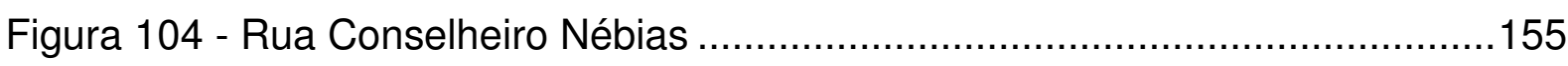

Figura 105 - Planta do centro de São Paulo, 1952/57 - leis de 1972 .....................156

Figura 106 - Avenida Radial Leste-Oeste, Viaduto Júlio de Mesquita Filho............158

Figura 107 - Avenida Radial Leste-Oeste ...................................................158

Figura 108 - Vista do Viaduto 25 de Março ........................................................159

Figura 109 - Vista do Viaduto 25 de Março .......................................................159

Figura 110 - Rua Senador Feijó ....................................................................160

Figura 111 - Planta do centro de São Paulo,1974 - leis de 1991 a 1997 ................161

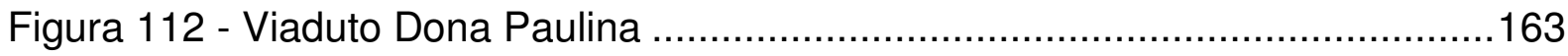

Figura 113 - Rua Antonio de Godói, com Largo do Paissandu ................................164

Figura 114 - Rua 25 de Março....................................................................164

Figura 115 - Praça Doutor João Mendes com Rua Riachuelo ...............................165

Figura 116 - 1893 - Trecho da região central de São Paulo ..................................165 


\section{1- INTRODUÇÃO}

A bibliografia especializada em retratar projetos construídos no espaço urbano enfoca, de maneira geral, o resultado final técnico e formal de tais projetos. Há publicações que tratam do assunto do ponto de vista iconográfico, outras abordam a relevância conceitual da construção e sua relação com a cidade. As informações a respeito de como se chega à obra construída são focadas de acordo com um recorte específico, como por exemplo, a bibliografia "temática", cujo enfoque é dividido por "categoria de projeto" ou de "autoria". Publicações especializadas como estas últimas, quando bem elaboradas, analisam o programa de necessidades ou a abordagem conceitual como resolução do problema espacial em questão.

Já as publicações periódicas têm cada qual o seu ponto de vista para tratar da obra construída, apresentando-a com ênfases diferentes: algumas no conceito, outras no detalhamento técnico de projeto, à exceção dos impressos que expõem o projeto por imagens de modelos reduzidos ou modelos virtuais, com pequenos textos conceituais. As publicações periódicas chegam a descrever entrevistas com projetistas, que falam de problemas cotidianos para administrar o projeto, de como organizar equipes maiores ou menores, entre outros assuntos.

São publicadas poucas informações a respeito de como a regulamentação urbana caracteriza o espaço construído da cidade. Se não há informações abundantes a respeito desta caracterização, talvez esta não seja relevante. Porém, se as obras construídas seguem os padrões estabelecidos pela legislação urbana, por que não se publicam informações críticas a esse respeito em maior quantidade? Talvez por que seja um ponto de vista a ser recortado por trabalhos mais aprofundados e não por publicações periódicas, de leitura mais dinâmica e enfoque mais pragmático. Partindo-se desta suposição, este trabalho propõe-se a esse aprofundamento, na cidade de São Paulo.

Pode-se supor que, para determinados tipos de publicações, como as periódicas especializadas em expor obras construídas, talvez não haja interesse em publicar 
informações que evidenciem a caracterização de edificações pela legislação urbana, mas isso não quer dizer que esta relação não exista.

Entendendo-se que cidades são reflexos da geografia e do sistema político, social e econômico de um país, pode-se dizer que são também constituídas em função de seus planos diretores ou da ausência dos mesmos, definindo-se o ambiente urbano para o convívio humano em função de sua escala e do número de habitantes. Estudos a respeito destas aglomerações humanas compõem as pesquisas a sobre do meio urbano, fruto da coexistência de inúmeros grupos de pessoas durante determinado período. Tais pesquisas têm sua qualidade em função de sua abordagem, especificidade e também em função de seus objetos de estudo. Ou seja, não se pode esperar que tais pesquisas produzam análises e conclusões sobre todos os aspectos inerentes às aglomerações humanas. Deste modo, em busca de uma melhor qualidade de dados, o foco deste trabalho é a regulamentação de construções na cidade de São Paulo.

Verifica-se que a legislação urbana paulistana desenvolveu-se de maneira mais expressiva após a proclamação da República, possivelmente, em função do grande crescimento urbano, ocorrido a partir daquele momento, associado à reorganização política da cidade de São Paulo, decorrente da primeira Constituição Republicana do Brasil de 1891. Deste modo, justifica-se a análise de obras construídas a partir daquela data, a fim de identificarem-se informações que contribuam para o entendimento da evolução da regulamentação urbana de São Paulo.

Lembrando que a Escola Politécnica de São Paulo teve sua fundação autorizada em 1892 e regulamentada em 1893, seria interessante analisar-se um período a partir do qual engenheiros e engenheiros-arquitetos formados no Brasil já estariam participando ativamente da construção civil paulistana.

Como a construção civil tem grande inércia para absorver novas teorias, técnicas e tecnologias, seria interessante analisarem-se leis e obras criadas a partir do início do século $\mathrm{XX}$, momento em que possivelmente os diplomados no Brasil já estariam interferindo na regulamentação das construções, pelo início de sua atividade profissional. 
Historicamente a cidade de São Paulo evidencia sua constante reconstrução a partir da eliminação de estruturas urbanas e edificações inadequadas aos planos de seus dirigentes, investidores imobiliários e grupos sociais mais influentes. Partindo-se destas considerações, seria relevante identificarem-se características de edificações capazes de evidenciar as revisões da legislação urbana da cidade de São Paulo ao longo dos anos. Para tal, estudar-se-á o período de aplicação das leis que regulamentaram a construção civil paulistana entre 1901 e 2000, buscando-se verificar possíveis reflexos da consolidação das leis de zoneamento com a Lei oㅜ 7.805, de $1^{\circ}$ de novembro de 1972, não enfocando o espaço edificado em função da aplicação das leis criadas no século XXI. Portanto, não entrando no mérito da Lei no 13.885 de 25 de agosto de 2004 - Novo Zoneamento do Município de São Paulo, cujos reflexos poderão ser verificados nas próximas décadas deste novo século.

As edificações particulares formam a maior parcela da paisagem urbana, coexistindo com pontuais construções para fins da administração ou uso público. Deste modo, a fim de se evidenciar a aplicação da legislação urbana no espaço edificado da cidade de São Paulo, serão estudadas algumas obras que tenham sido criadas a priori para fins privados. Como diria REIS (1970), a arquitetura não é uma conseqüência direta das condições sociais, caso contrário, para condições idênticas haveria sempre a mesma arquitetura. Transpondo-se esta análise para a legislação urbana, pode-se supor que apesar de ser a mesma para as obras da cidade de São Paulo não deve tê-las caracterizado da mesma maneira.

Sob um recorte urbano pode-se entender que um lote privado edificado é fruto de diversas variáveis, como por exemplo, do processo de projeto, da bagagem intelectual dos responsáveis por sua construção (contratante, projetistas e executores), sendo reflexo também de sua finalidade e de sua ligação direta ou não às regras de mercado. Estas variáveis citadas acima podem ser vistas como estruturas que caracterizam as edificações. Segundo ZMITROWICZ (1997), os edifícios podem ser entendidos como fluxos urbanos, que são organizados por estruturas que os precedem. Neste trabalho será analisada a legislação urbana de São Paulo a fim de verificar se sua presença como estrutura urbana foi capaz de caracterizar os edifícios privados paulistanos, entendidos aqui como fluxos. 
Assim como as edificações, a paisagem urbana é um fluxo que tem começo e fim. Desde sua materialização até sua extinção é passível de análises, pelas quais se podem evidenciar alterações físicas de suas partes em função do tempo. Entendendo-se a paisagem urbana como um conjunto de edificações (predominantemente) privadas, considera-se que estas últimas sejam as partes ou partículas formadoras desta paisagem. Ao analisarem-se tais partículas, em determinado período, seria possível perceber transformações ocorridas na paisagem em função das alterações das estruturas que conformaram estas partículas, isto é, que caracterizam os edifícios privados, neste trabalho vistos como fluxos urbanos.

Sendo as estruturas os condicionantes dos fluxos, deve-se analisá-las a partir de seu modelo formador, ou seja, o modelo de recorte da realidade dos responsáveis por sua criação. Esta análise pode levar ao encontro de estruturas físicas e nãofísicas, que são sempre ligadas ao tempo. Parafraseando, em uma cidade, pessoas e alimentos podem ser entendidos como fluxos e suas estruturas condicionantes físicas e não-físicas podem se sobrepor. Por exemplo, o trajeto de pedestres é estruturado fisicamente por ruas e calçadas. Estas por sua vez, além de físicas são não-físicas quando analisadas no momento de sua criação. Não se criam ruas e calçadas sem projeto ou meta, sem que haja um plano político que as justifique, sem que haja verba vinculada e/ou limitada para este fim, em determinado período. Do mesmo modo, são os alimentos estruturados fisicamente em caixas, vasilhames, sacos ou fardos, sendo transportados em veículos por rodovias, ferrovias ou hidrovias. Essas estruturas citadas, além de físicas são não-físicas se analisadas no momento de sua definição, no momento da escolha por uma ou outra. Deste modo, sem análise associada ao período em que se enquadra uma estrutura, não se chega a uma definição precisa de sua natureza, seja física ou não-física.

Neste trabalho entende-se que os lotes de terra urbana são estruturas físicas condicionantes das obras neles edificadas, assim como as vias são estruturas físicas condicionantes dos lotes. Ambos, lotes e vias, podem ser estrutura não física se analisados no momento de sua criação. Sob o mesmo ponto de vista, a legislação urbana é estrutura não-física do espaço construído na cidade e neste trabalho é entendida como um conjunto de leis urbanísticas e de leis edilícias:

- legislação urbanística, que trata do parcelamento, uso e ocupação do solo; 
- legislação edilícia, que trata das questões relativas a construções, a obras e a aspectos internos das edificações.

Sendo assim, este trabalho buscará responder se há evidência da caracterização da paisagem urbana na cidade de São Paulo, no século $X X$, a partir da aplicação de leis edilícias e urbanísticas em propriedades particulares. Porém, levando-se em conta a grande área urbanizada desta cidade e a impossibilidade de analisá-la em sua totalidade nesta pesquisa, no próximo capítulo será definido o perímetro de estudo no qual serão buscadas as evidências da aplicação das leis urbanas. 


\section{2- DEFINIÇÃO DO OBJETO DE ESTUDO}

As palavras derivadas de urbs, nos dicionários portugueses do século XVIII, associam-se aos bons modos de cidadãos e opõem-se à grosseria de camponeses. No século XIX a palavra é associada à idéia de civilização (LEME, 2000, p.5).

Na visão de ZMITROWICZ (1979), a aglomeração humana faz parte do sistema de relações estabelecido entre áreas urbanas e rurais, formado por elementos que correspondem às necessidades de indivíduos desta aglomeração. Sob a forma de cidade, ela constitui a parte do sistema em que o solo é utilizado como apoio de suas estruturas físico-espaciais. Assim, entende-se cidade como o espaço edificado, isto é, o conjunto de áreas construídas e redes físicas de água e esgoto, elétrica, dados, telefonia, entre outras.

Para SOUZA (PORTA et al, 2004), a dinâmica da cidade não pode ser vista como um movimento espontâneo, pois segue regras sociais que expressam a indissociabilidade entre objetos e ações. As ocorrências na cidade seguem a lógica social estabelecida pelos grupos de indivíduos que coexistem no espaço geográfico em questão.

Pode-se dizer que o espaço urbanizado da cidade é o palco dos conflitos de interesse entre os diversos grupos de pessoas que nele estabelecem relações físicas, interpessoais e sociais. As divergências de intenções e conseqüentes sobreposições de idéias se materializam em construções urbanas, como reflexos do comportamento dos indivíduos responsáveis pelo empreendimento destas obras edificadas. Cada indivíduo ou associação de indivíduos age de acordo com seu grupo ou classe social. As edificações são evidências físicas da maneira pela qual os habitantes de determinado território se apropriam do solo em aglomerações humanas sob a forma de cidade. No século XIX, na última década do império no Brasil, a cidade de São Paulo apresentava concentração da população em sua região central, estabelecida em uma área urbanizada com pouco mais de 290 hectares. 
Figura 01 - Área Urbanizada, cidade de São Paulo - 1881

(aproximadamente 290 ha de área urbanizada)

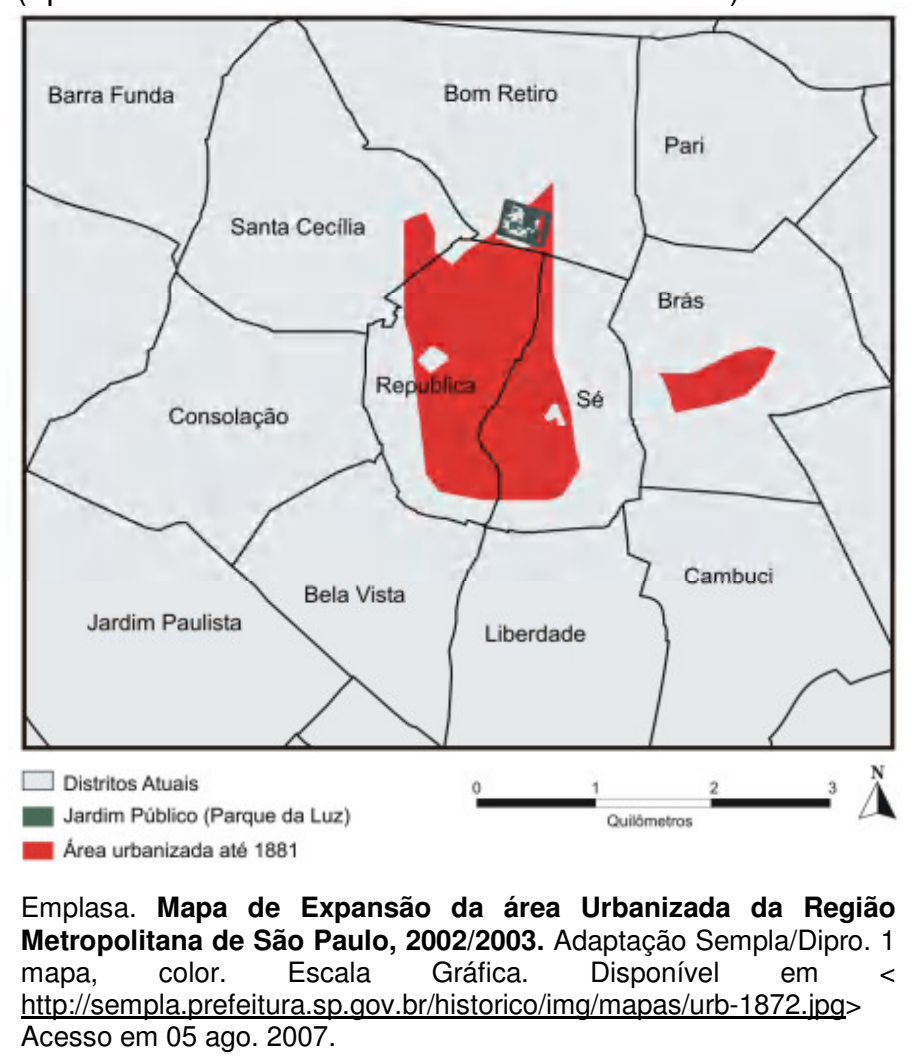

Segundo LEFÈVRE (2006), no centro da cidade de São Paulo, identifica-se a marca das transformações da sociedade como um todo e por isso esta área assume um caráter extremamente significativo para a compreensão de tais transformações.

Em sua definição sobre o conceito de moderno, CAMPOS NETO (1999) diz que o moderno está ligado à idéia de medida justa, pois em sua raiz latina é derivada de modus, que significa medida, ou medida certa. Ainda de acordo com este autor, por trás do sentido dominante, temporal, como portador do novo, é latente o sentido de modelo. Moderno denota o que pertence ao agora (do latim, modernus), caracterizando traços do período atual, contrapondo-se ao que se vê como ultrapassado.

No início da República, enquanto Campinas (o centro da zona cafeeira) e Santos (o porto de ligação com o mundo) estavam marcadas pela febre amarela e varíola, a cidade de São Paulo assumiu a característica de importante centro econômico da nação. Antonio da Silva Prado, o primeiro prefeito da cidade, teve grande responsabilidade no processo de modernização de São Paulo. 


\section{Figura 02 - 1893 - Região central de São Paulo}

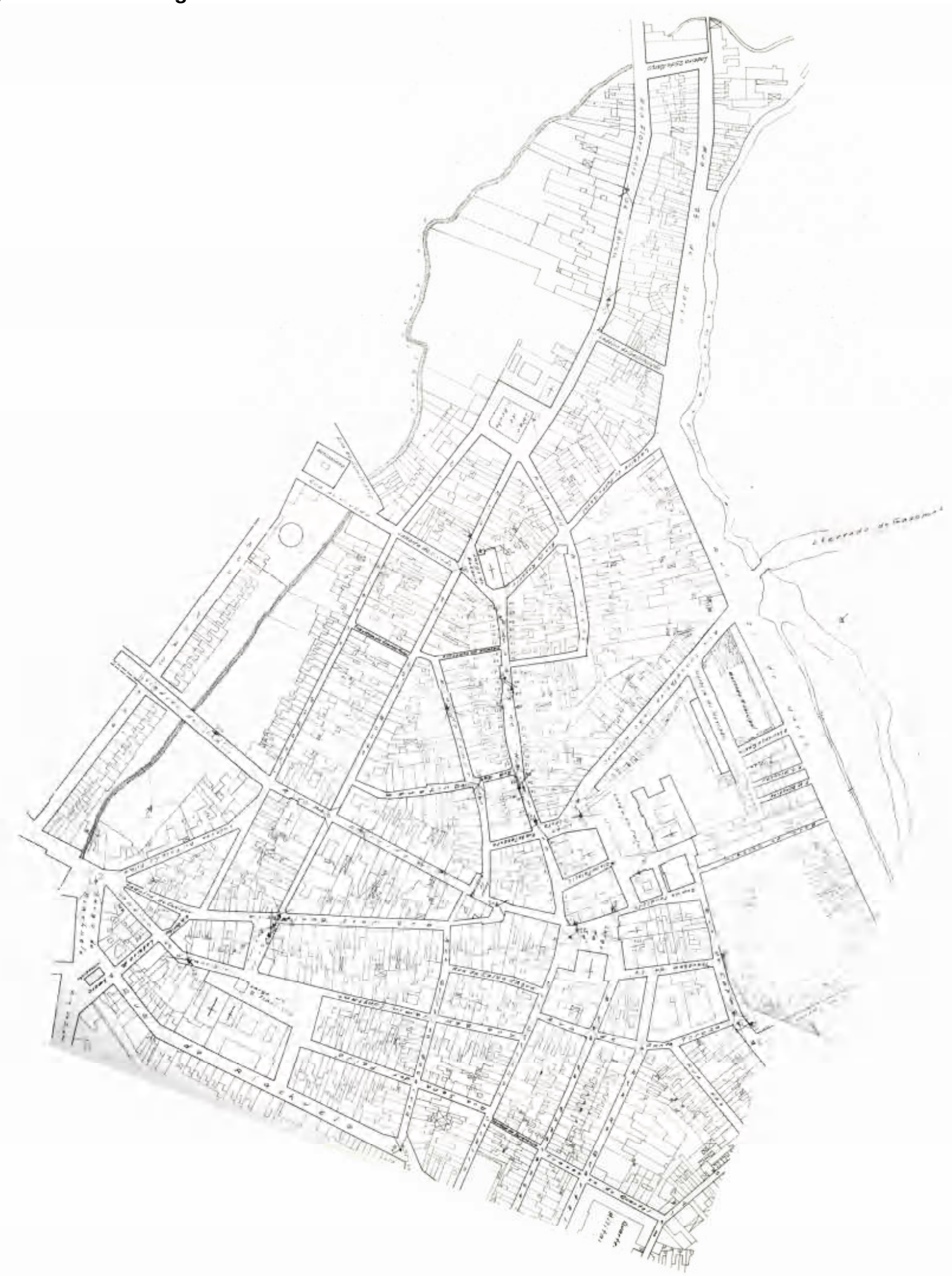

Planta da área central da cidade de São Paulo - levantada pelo engenheiro V. Huet de Bacellar em 1893. in: TOLEDO, Prestes Maia e as origens do urbanismo moderno em São Paulo. São Paulo, Empresa das Artes, 1996, p.68. 
CAMPOS NETO (1999) relata que Antonio Prado formou a diretoria de obras municipais, contando com oito engenheiros, dentre eles, Victor da Silva Freire ${ }^{1}$, professor da Escola Politécnica, e um estudante da mesma escola, Arthur Saboya. Deste modo, tomavam parte no corpo de engenheiros da Diretoria de Obras de São Paulo professores da Politécnica, assistidos por jovens formados em suas primeiras turmas. A estrutura organizacional do setor de obras paulistano caracterizava-se por ser constituída e conduzida por profissionais de formação específica para essa atividade (engenheiros civis e engenheiros-arquitetos) e pelo estreito contato com o mais expressivo órgão de difusão de conhecimento de então, a Escola Politécnica.

Figura 03 - Largo de São Bento, ano 1900

(esquina com Rua Boa Vista)

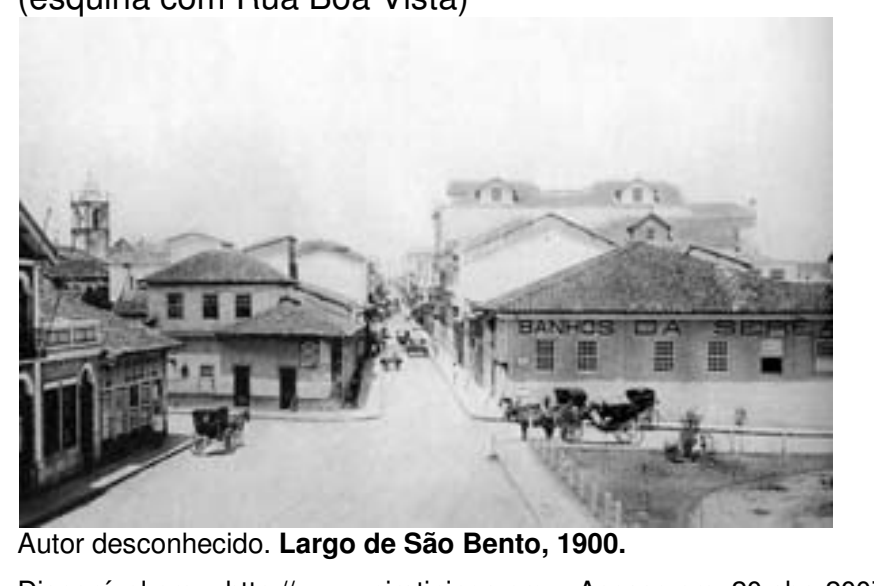

Disponível em: <http:// www.piratininga.org>. Acesso em: 20 abr. 2007

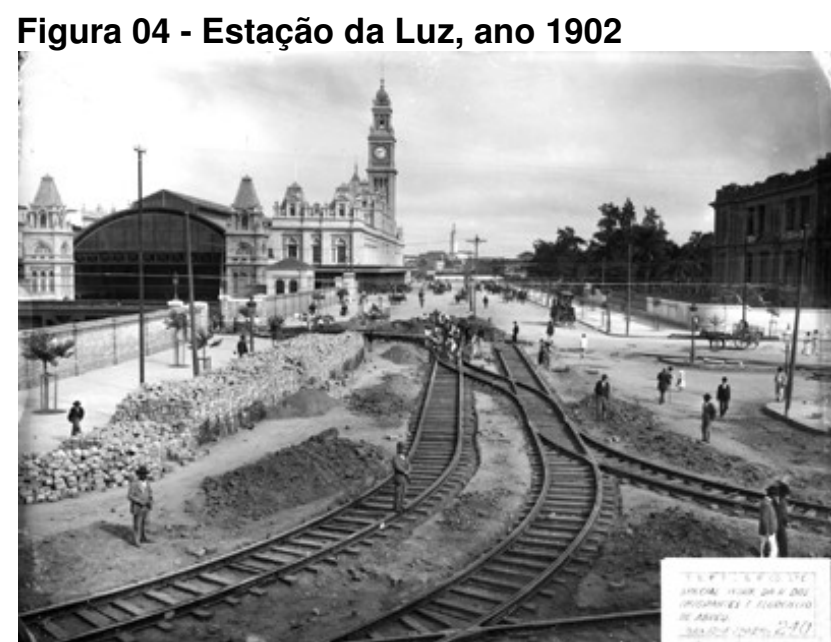

Autor desconhecido. Colocação de trilhos na Estação da Luz, 1902. Disponível em: <http://www.stm.sp.gov.br/pitu2020>.

Acesso em: 25 abr. 2007

\footnotetext{
${ }^{1}$ Victor da Silva Freire estudou na Escola Politécnica de Lisboa e na Ecole des Ponts et Chaussés de Paris. De 1899 a 1925 dirigiu o Setor Municipal de Obras de São Paulo (Toledo, 1996, p.278).
} 
As imagens da página anterior retratam a o Largo de São Bento e a Estação da Luz, exemplos do que se via como ultrapassado na cidade, frente à modernização da paisagem urbana, neste caso em função das novas tecnologias inerentes ao transporte sobre trilhos. No início do século passado, São Paulo deparava-se com questões decorrentes da posição do Brasil no sistema internacional de comércio, assim como as demais cidades brasileiras. Como nação agro-exportadora, o país tinha de atingir internamente o nível condizente com sua função internacional, pela reconfiguração do espaço urbanizado de seus centros regionais, portos e capitais, que surgiam como referência dentre as aglomerações urbanas sob as quais se baseava o sistema produtivo do país naquele momento. De acordo com ANDRADE (1966), são duas as fases chamadas de período pré-urbanístico brasileiro: a sanitarista e a da circulação. A primeira, resultado da luta pela sobrevivência - frente às péssimas condições de salubridade - e de preocupações anteriores com diferentes problemas vividos no período colonial. A segunda fase surge com a afirmação e expansão da indústria, com a introdução do automóvel, tendo como fator de produtividade o tempo, limitando-se a obras físicas no ambiente da cidade, rearranjando plasticamente a perspectiva urbana, desenvolvendo técnicas de engenharia e introduzindo equipamentos.

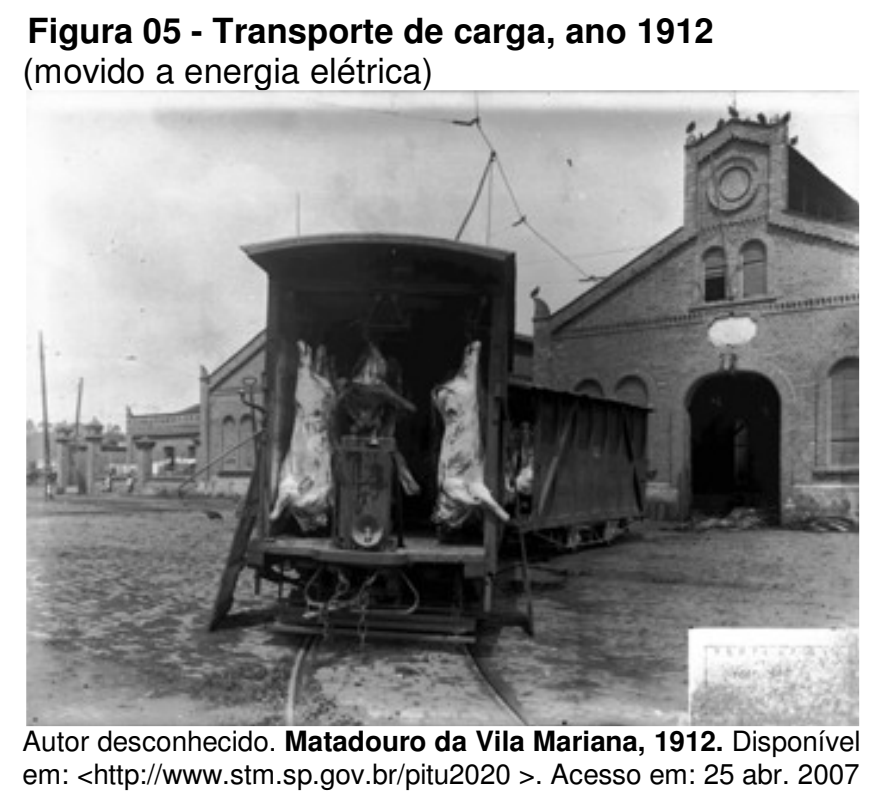

As questões urbanas que caracterizaram a fase pré-urbanística, como as de abastecimento público e alojamento, de salubridade e circulação, definiram o cenário a ser enfrentado pela administração municipal paulistana. A imigração interferiu na 
força de ação comunitária pré-existente, pois introduziu novos indivíduos no tecido social local, diluindo a força e a homogeneidade de grupos que começavam a vislumbrar sua identidade própria. A política e os interesses inerentes à economia industrialista comprometeram a vigência da ordem existente a partir da mudança de paradigmas e demandas da aglomeração humana que se expandia. ANDRADE (1966) menciona que a Prefeitura Municipal de São Paulo, com normas urbanas ultrapassadas, que não correspondiam ao panorama físico-social da cidade (Código de Posturas de 1886), perdeu o poder de controle sobre o uso e ocupação do espaço urbano. Desta maneira, passado a utilizar até meados de 1918 um conjunto de regras mais adequadas ao cenário que havia se configurado, o Código Sanitário Estadual de 1894.

Como o período de estudo deste trabalho enquadra-se entre 1901 e 2000, no que diz respeito à legislação, serão estudadas e apresentadas no capítulo 4 as regulamentações criadas neste período, mas também leis criadas no fim do século $\mathrm{XIX}$, que tenham regulamentado as construções paulistanas no início do século XX.

ROLNIK (2003) oferece informações importantes, ao discorrer sobre plantas da cidade, comparando dados de 1914 e 1930. Em 1914, a área ocupada em São Paulo era de 3.760 hectares (ha) com densidade populacional média de 110 hab/ha.

Figura 06 - Área Urbanizada, cidade de São Paulo - 1882/1914 (3.760 ha de área urbanizada, com 110 hab/ha)

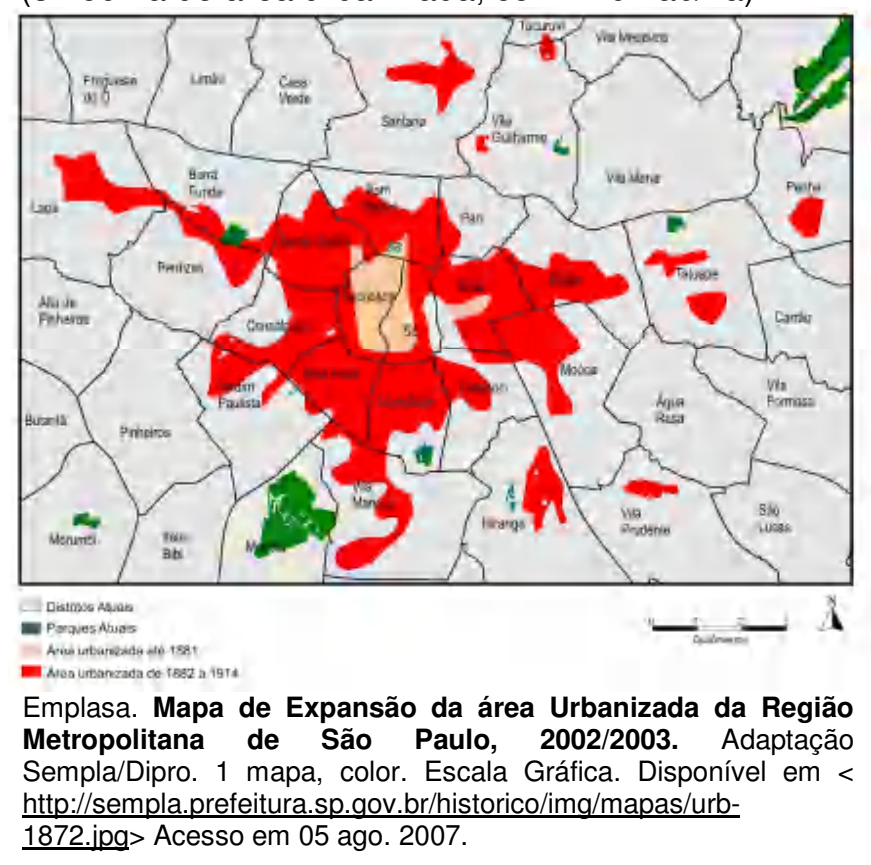


Novas tecnologias, inclusive as de transporte, começavam a ser incorporadas a fim de lidar com as diferentes escalas urbanas e questões cotidianas de áreas urbanizadas do município de São Paulo.

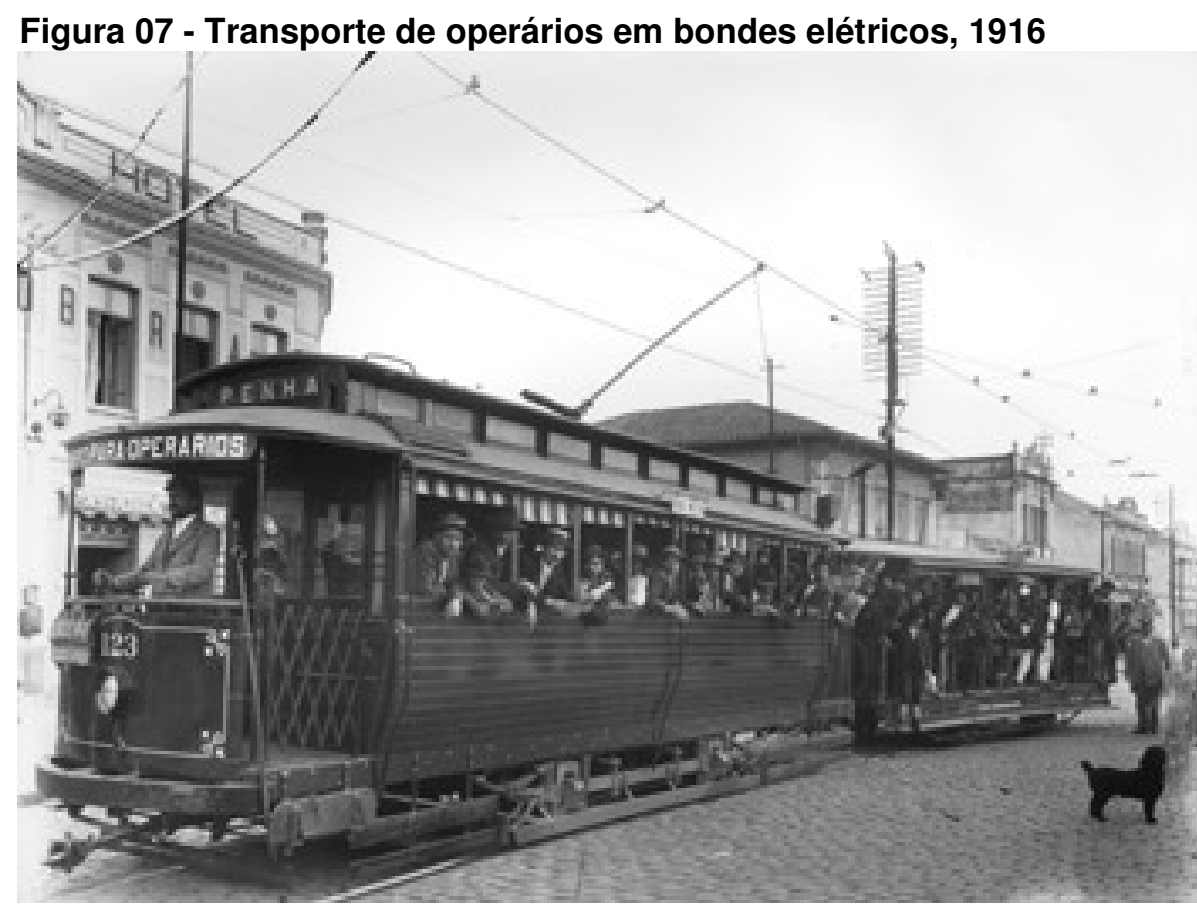

Autor desconhecido. Transporte de operário, 1916. Disponível em:

<http://www.stm.sp.gov.br/pitu2020/retrospec/historia.htm>. Acesso em: 25 abr. 2007

Este foi um período de transição de conceitos, demandas e hábitos em São Paulo.

Figura 08 - Trânsito de animais X Transporte a tração mecânica, 1916

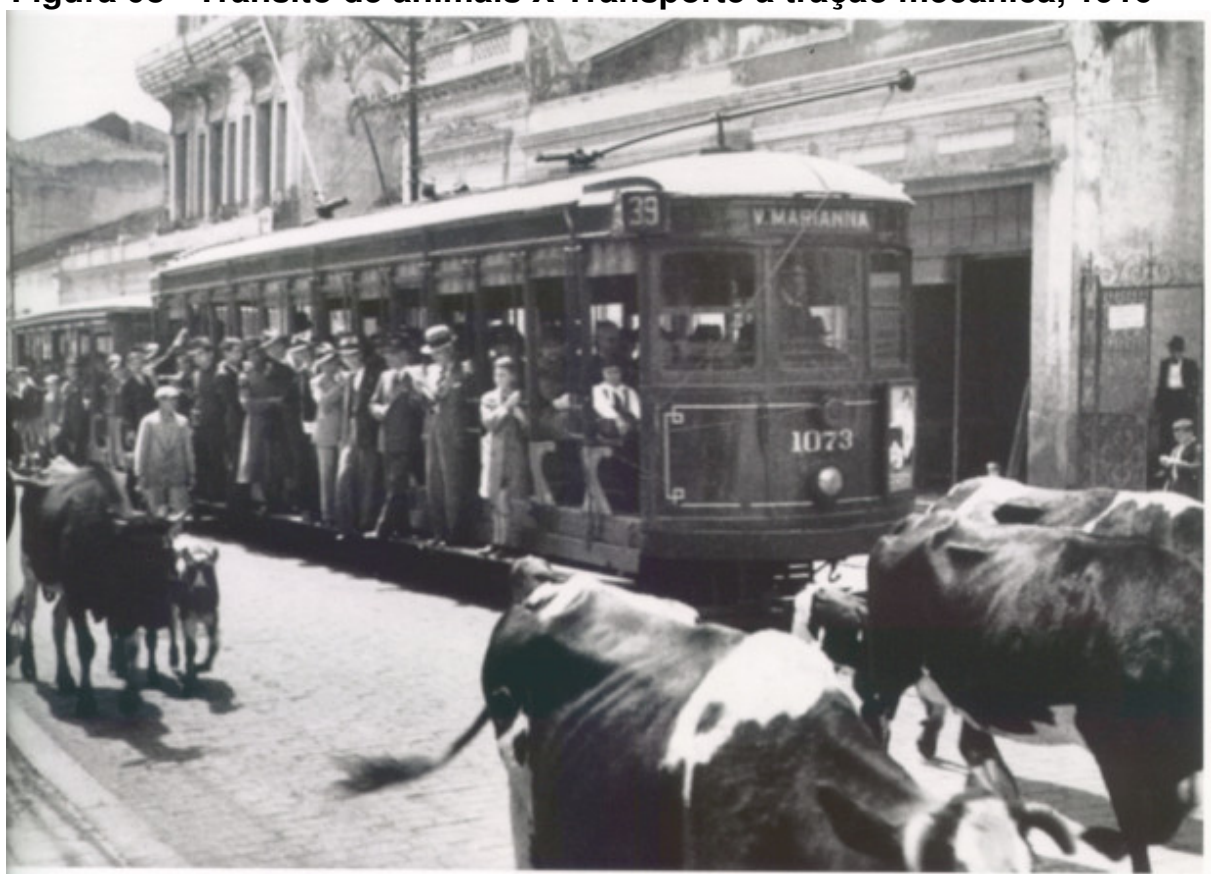

Autor desconhecido. Linhas de Bonde, 1916. Disponível em:

<http://www.stm.sp.gov.br/pitu2020/retrospec/historia.htm>. Acesso em: 25 abr. 2007 
Figura 09 - Praça da Sé, 1916

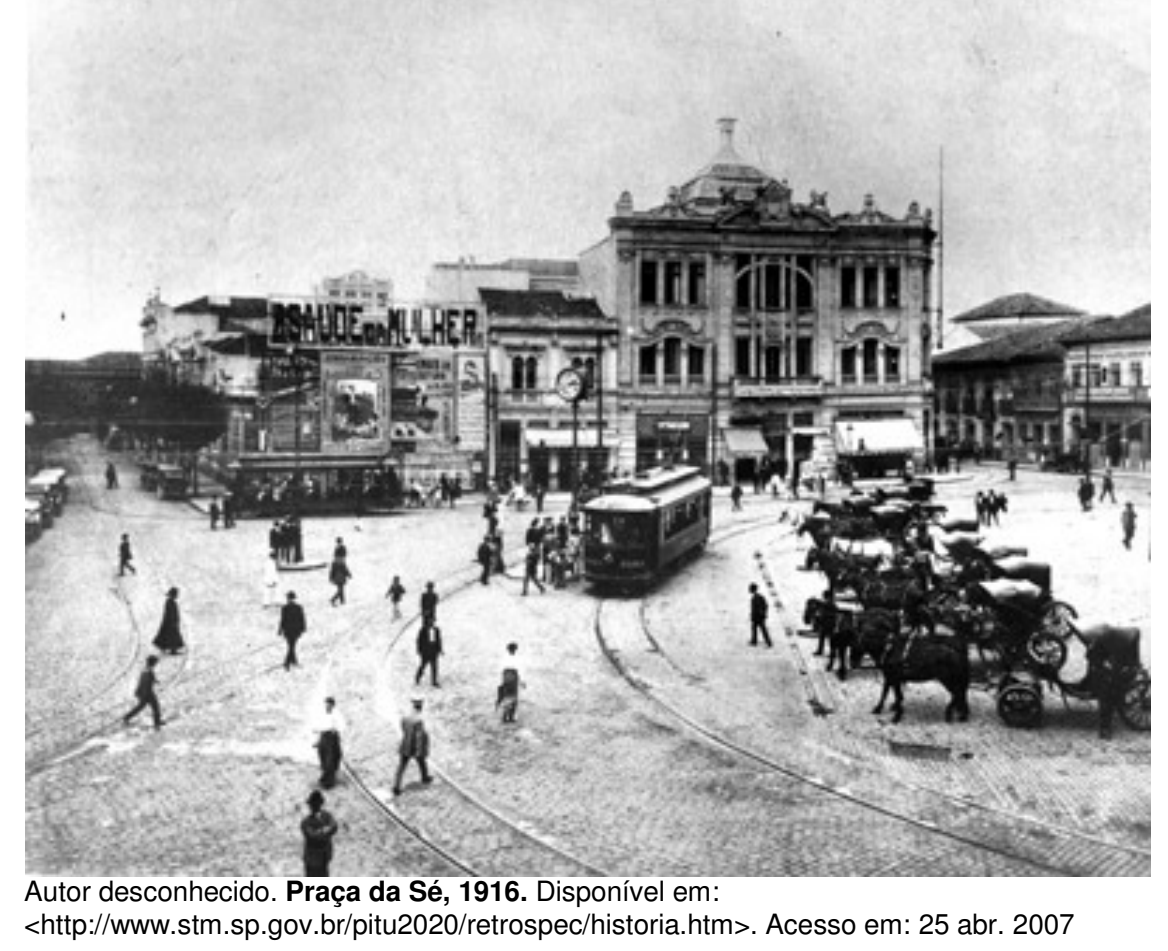

De 1881 a 1914 a área urbanizada do município de São Paulo cresceu 13 vezes. Após a Primeira Guerra Mundial, ainda em busca da sobrevivência e lutando contra as más condições de salubridade, constataram-se relevantes alterações da rotina paulistana, principalmente pela intensificação da produção e facilitação do acesso às novas tecnologias de transporte. Pode-se imaginar que, à primeira vista, os efeitos imediatos causados pelo monóxido de carbono não deviam ser piores do que os odores provenientes de dejetos inerentes ao transporte de tração animal.

Figura 10 - Praça da Sé, 1920

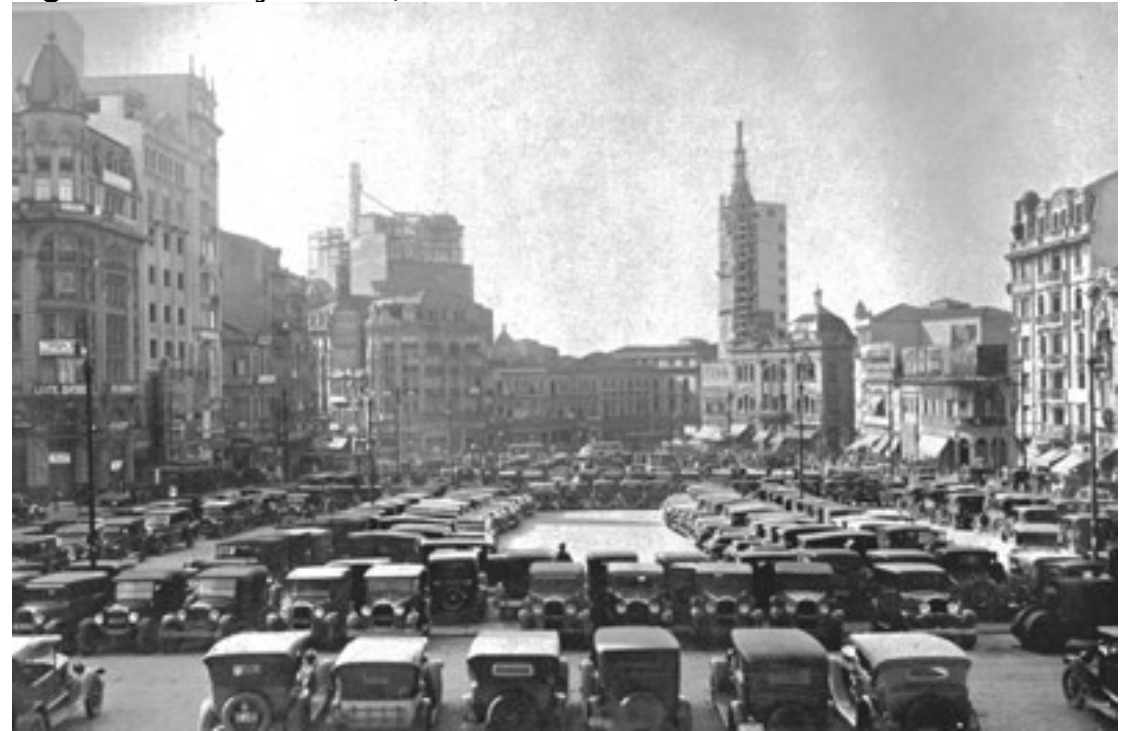

Autor desconhecido. Estacionamento de carros na Praça da Sé, 1920. Disponível em: <http://www.stm.sp.gov.br/pitu2020/retrospec/historia.htm>. Acesso em: 25 abr. 2007 


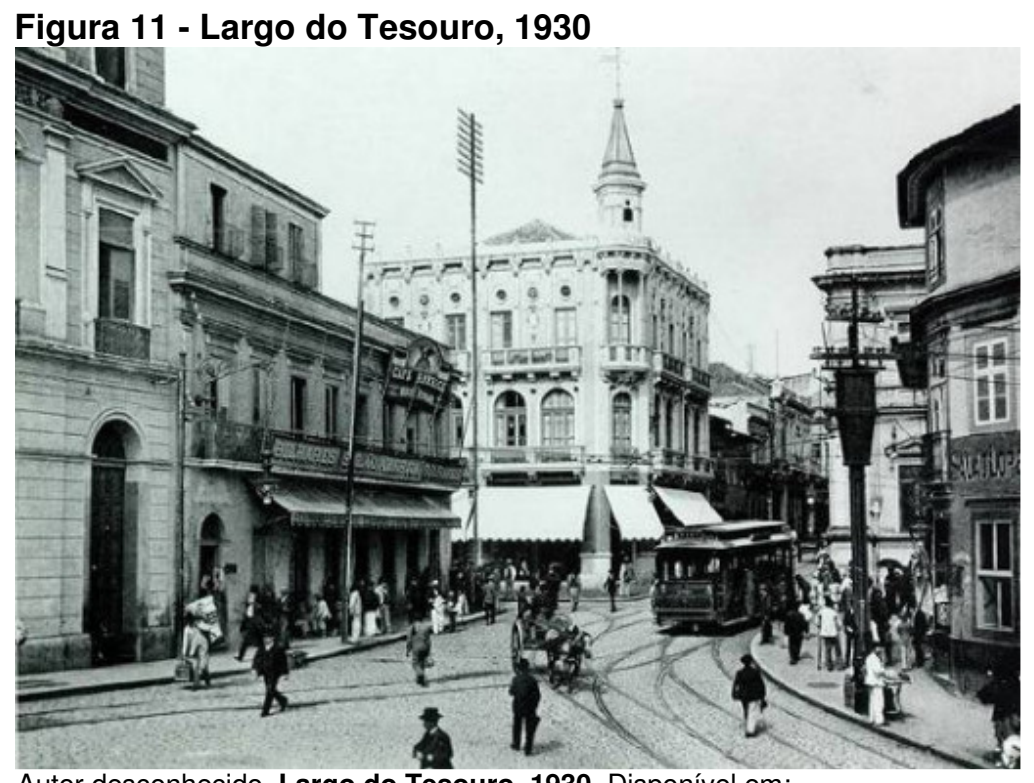

Autor desconhecido. Largo do Tesouro, 1930. Disponível em:

<http://www.stm.sp.gov.br/pitu2020/retrospec/historia.htm>. Acesso em: 25 abr. 2007

De 1881 a 1930, a área urbanizada paulistana cresceu 61 vezes, sendo que a densidade populacional média passou a ser 58\% menor. De 1930 até a década de 1970, a densidade populacional média se manteve constante, com cerca de 50 hab/ha. (PORTA et al, 2004, p. 546).

Figura 12 - Área Urbanizada, cidade de São Paulo - 1915/1929 (17.653 ha de área urbanizada, com 47 hab/ha)

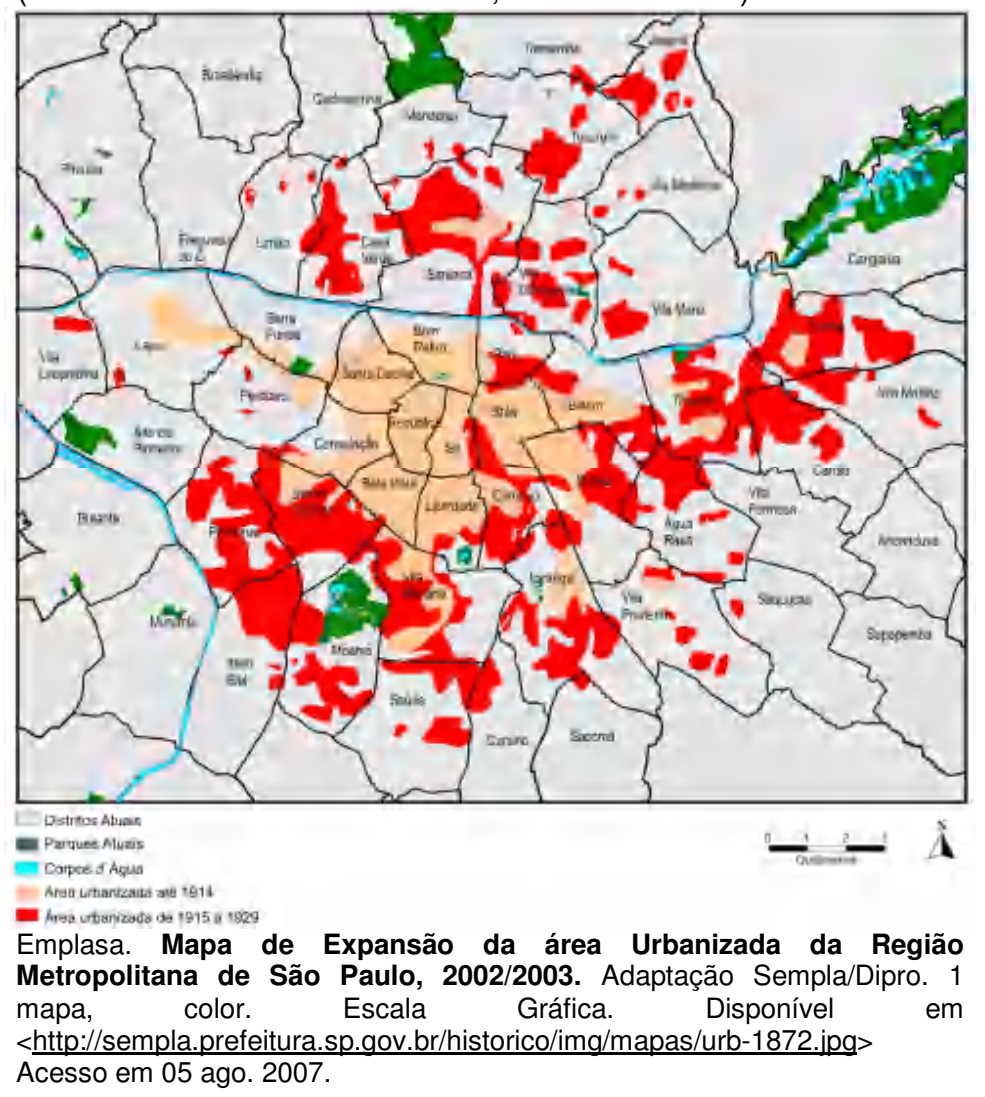


A crise do modelo de exportação agrícola brasileiro em 1929, decorrente da conjuntura internacional, e a revolução de 1930, são considerados por diversos autores como o início da reordenação econômica e política do país. Com o golpe militar de Getúlio Vargas em 1937, verificou-se a perda da hegemonia política da oligarquia cafeicultora, com maior intervenção do Estado na economia, fortalecimento do Poder Central e enfraquecimento dos Estados Federados. Neste período verifica-se a transição da atividade econômica baseada na agro-exportação para a atividade industrial.

Os anos de 1929 a 1950 são de grande importância para a formação da metrópole paulistana quanto a sua acomodação à nova perspectiva econômica, tendo como uma das conseqüências a grande verticalização do centro da cidade, vista por muitos como reflexo de uma identidade urbana moderna. Segundo REIS (1970), desaparecera a uniformidade dos esquemas das residências, que fora o traço marcante da fase colonial.

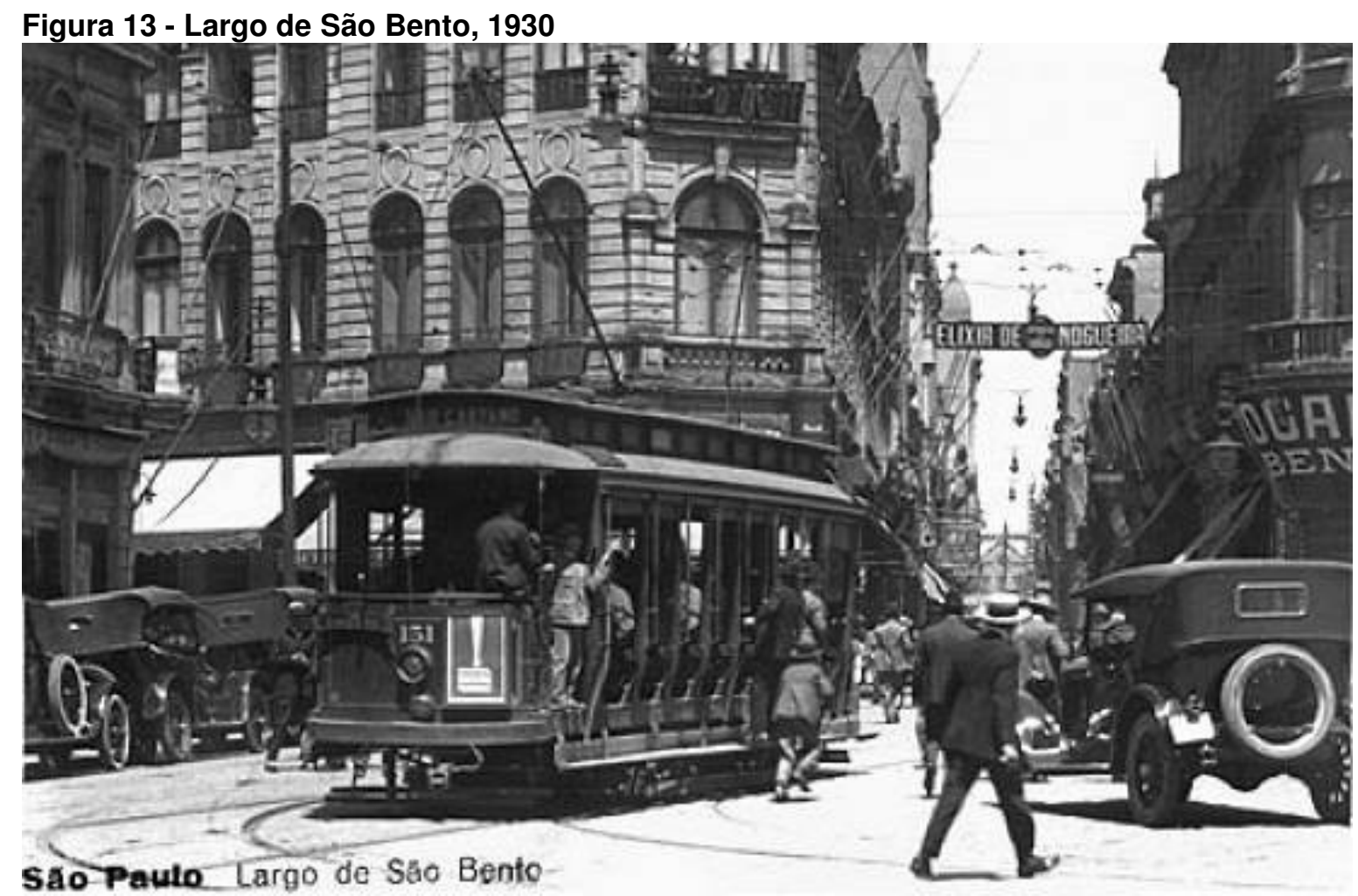

Autor desconhecido. Largo de São Bento, 1930.

Disponível em: <http://www.stm.sp.gov.br/pitu2020/retrospec/historia.htm>. Acesso em: 25 abr. 2007 
Com a presença da indústria de base brasileira e intensificação da industrialização em São Paulo, após o fim do regime autoritário de Getúlio Vargas em 1945, passou a haver grande necessidade de controle, ordenamento e regulação do uso do solo paulistano, em função da presença de uma grande população urbana que tinha muita dificuldade para se acomodar no território urbanizado. Para alguns autores o Plano de Avenidas de Prestes Maia é o ponto de inflexão entre a cidade de São Paulo europeizada, reflexo da sociedade estruturada na exportação do café, e a cidade cuja atividade econômica principal é a da produção industrial. Os projetos de embelezamento de áreas utilizadas pela oligarquia cafeicultora paulistana são substituídos por planos viários que facilitam a circulação das mercadorias e das pessoas, sendo que o solo urbano caracteriza-se também como mercadoria. A evolução do Plano de Avenidas, consolidado mais de 20 anos após os primeiros estudos de 1925, pode ser verificada nas figuras expostas a seguir. Vale ressaltar que, apesar da essência funcionalista deste plano, o caráter de embelezamento da cidade, recorrente no início da República, fez-se presente pela delimitação de pontos estratégicos para a implantação de edifícios cujo porte adequava-se à nova escala urbana, criada com as novas e amplas avenidas.

Figura 14 - Avenida de Irradiação, 1ª. versão, J. F. Ulhôa Cintra

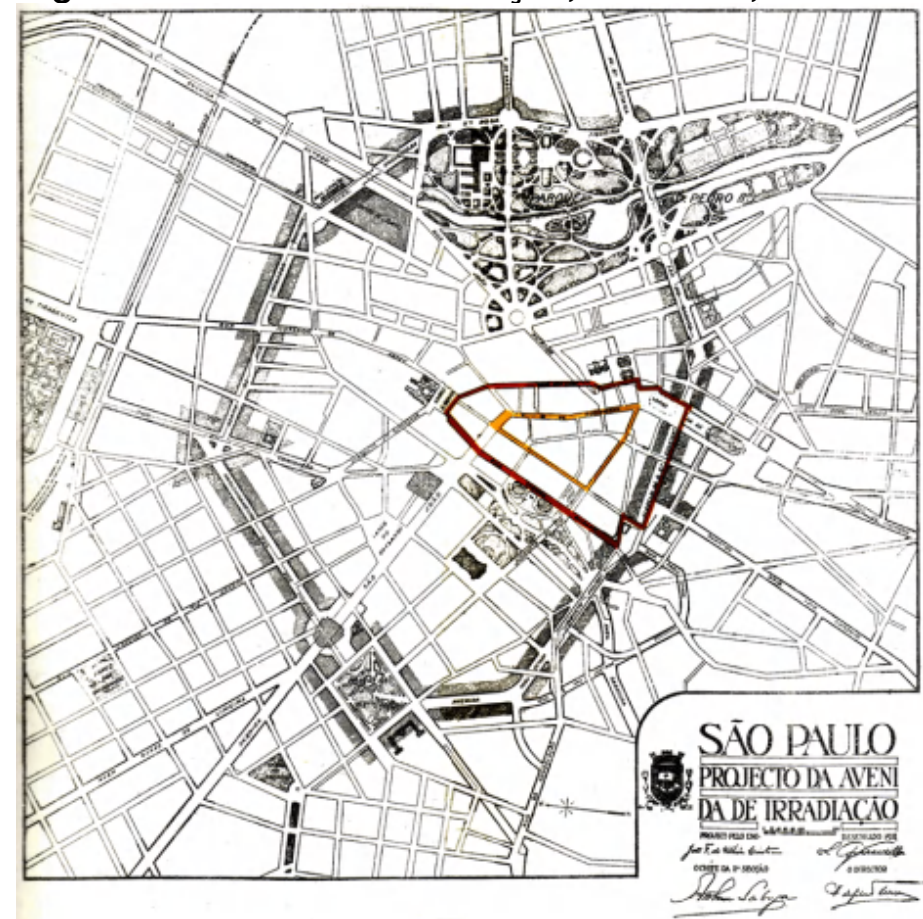

Planta do Boletim do Instituto de Engenharia. São Paulo, n.26-29, 31, 1925-26. in: TOLEDO, Prestes Maia e as origens do urbanismo moderno em São Paulo. São Paulo, Empresa das Artes, 1996, p.124. 
Por volta de 1920 Ulhôa Cintra ${ }^{2}$ propôs o chamado 'Perímetro de Irradiação', que foi reestudado em conjunto com o engenheiro Prestes Maia ${ }^{3}$ em 1924, e incorporado ao 'Plano de Avenidas' elaborado por este por encomenda do prefeito Pires do Rio em 1930. (...) O esquema teórico que serviu de base ao Plano de Avenidas foi o da combinação de vias radiais com vias perimetrais. Precisava ter algumas vias alargadas e ser completado com a abertura das avenidas de fundo de vale que atravessavam o centro. (...) O Plano de Avenidas pretendia, portanto, consolidar a posição predominante do centro principal e reforçar o caráter radiocêntrico do sistema viário, alterando, porém drasticamente a escala das vias e dos espaços abertos. A intenção era adequar a cidade ao crescimento de sua população e o número de veículos em circulação, claramente associado ao desenvolvimento de sua economia (LEFÈVRE, 1985, p.55).

Figura 15 - Avenida de Irradiação, 2a . versão

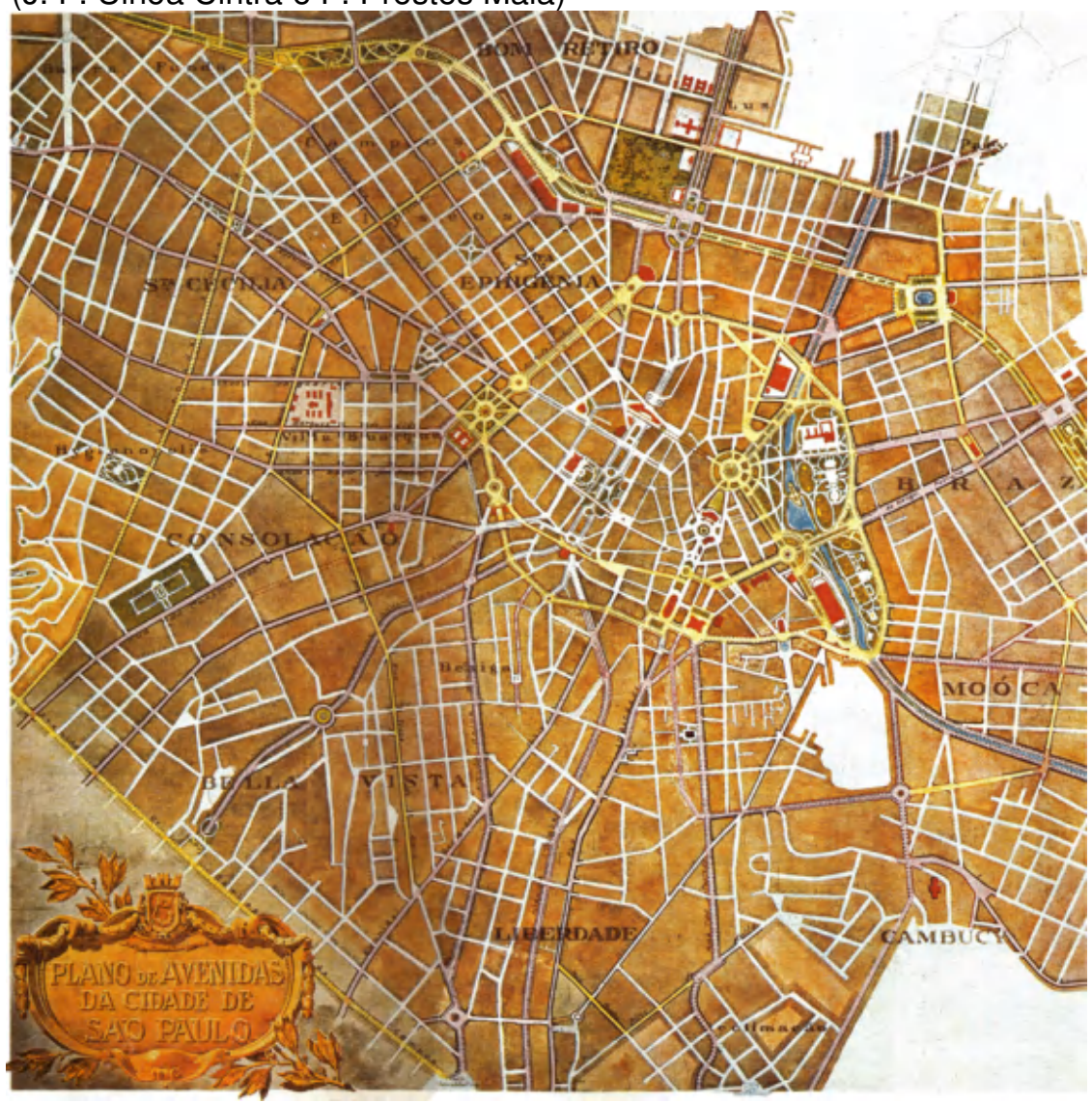

MAIA, F. P. Estudo de um Plano de Avenidas para cidade de São Paulo. São Paulo, Melhoramentos, 1930. in: TOLEDO, Prestes Maia e as origens do urbanismo moderno em São Paulo. São Paulo,

Empresa das Artes, 1996, p.147.

\footnotetext{
${ }^{2}$ João Florence de Ulhôa Cintra, engenheiro civil formado pela Escola Politécnica de São Paulo em 1911, começou a trabalhar na Prefeitura em 1910, ainda estudante, tendo permanecido no serviço público até seu falecimento em 1944, quando ocupava o cargo de diretor do Departamento de Obras da Prefeitura na gestão de Prestes Maia (TOLEDO, 1996, p.278).

${ }^{3}$ Francisco Prestes Maia, engenheiro civil e arquiteto formado pela Escola Politécnica de São Paulo em 1917, entrou para a Diretoria de Obras Públicas da Secretaria de Viação e Obras Públicas em 1918. Compôs o quadro de docentes da Escola Politécnica de 1924 a 1938 e foi prefeito da cidade de São Paulo de 1938 a 1945 e de 1961 a 1965, ano em que faleceu (TOLEDO, 1996, p.284).
} 
Segundo LEFÈVRE (2006), as formas e meios de circulação possíveis nos vários momentos de evolução da cidade caracterizam sua organização física. Não se tratando de relação exclusiva e de dependência, mas de uma relação extremamente forte, podendo até chegar a um ponto de dependência vital.

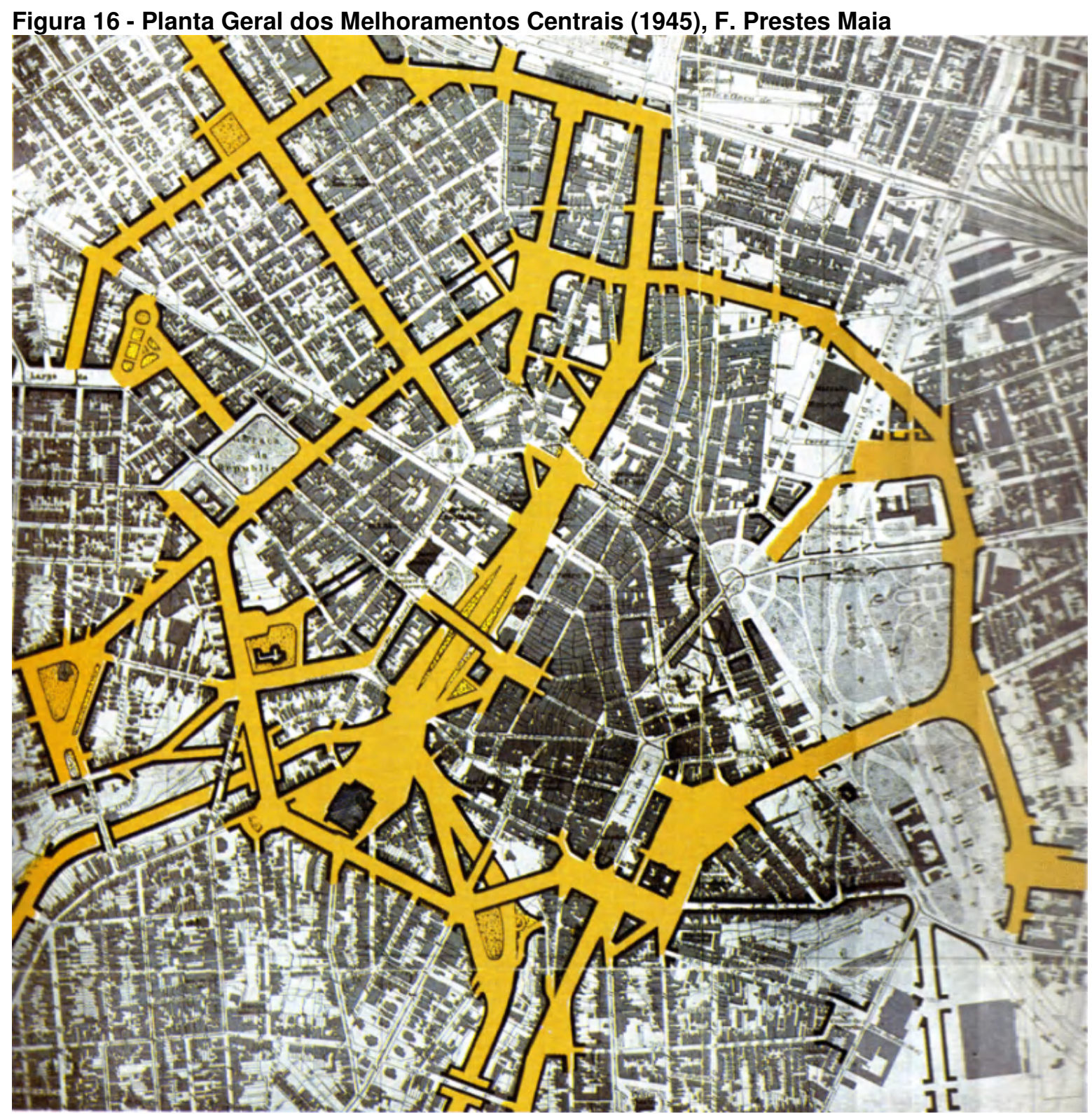

MAIA, F. P. Os Melhoramentos de São Paulo. $2^{\mathrm{a}}$ Ed., São Paulo, Prefeitura Municipal, 1945. in: TOLEDO,

Prestes Maia e as origens do urbanismo moderno em São Paulo. São Paulo, Empresa das Artes, 1996, p.151

Francisco Prestes Maia propôs que o financiamento das obras viárias do Plano de Avenidas viesse de fundos públicos como rendas ordinárias, empréstimos e taxa de melhoria. Defendeu que a coordenação dos transportes urbanos fosse serviço da prefeitura, com a definição das tarifas, abertura e extensão de linhas de bondes e ônibus (LEME, 2000, p72). 
De acordo com SOMEKH (1987), o centro de São Paulo, do começo do século passado até a década de 1940, passou por duas grandes intervenções urbanísticas. A primeira durante as administrações dos prefeitos Antonio Prado (1899 a 1911) e Raimundo Duprat (1911 a 1914), a segunda durante a administração do prefeito Prestes Maia (1938 a 1945).

Para CAMPOS NETOS (1999), no Brasil e no mundo, apesar de ser uma preocupação comum a criação de infra-estruturas viárias, de transporte e de outros equipamentos, apresentavam-se de diferentes maneiras a regulamentação e o controle, bem como as implicações sociais do urbanismo. Como reflexo da predominância do capital industrial, em países industrializados, propostas reguladoras representavam elemento central e abrangente das políticas urbanas. No Brasil, iniciativas reguladoras - essenciais para a funcionalidade e a racionalidade do espaço urbanizado - quando projetadas para toda a cidade, limitavam-se a qualificar trechos pontuais, escolhidos como vitrines para sediar e representar a oligarquia local.

No centro de São Paulo, expressivas transformações no uso e ocupação do solo ocorreram com a consolidação do anel de irradiação do Plano de Avenidas. No segundo pós-guerra, período aquecido para o mercado de construção civil na cidade, verificou-se rápida verticalização da região central em função da ampliação de escala de antigas vias - com legislação específica para tal - e abertura das novas avenidas radiais, em busca de facilitar o acesso ao centro, tanto por automóveis como por ônibus.

Nas primeiras décadas do século XX, a Prefeitura Municipal de São Paulo procurava manter certa harmonia quanto à altura dos prédios (HOMEM, 1984, P.59). A princípio, junto aos engenheiros e engenheiros-arquitetos educados na orientação européia, havia resistência quanto ao crescimento das edificações em altura. Para as elites brasileiras, mobilizadas por intenções transformadoras dos centros urbanos, a referência principal era o modelo de ocupação urbana parisiense. Nos meios técnicos essa orientação "Haussmaniana" mantinha sua força, amparada em uma história de aspirações, propostas e empreendimentos (CAMPOS NETO, 1999, p.132). 
Figura 17 - Modelo urbano presente em estudos para São Paulo

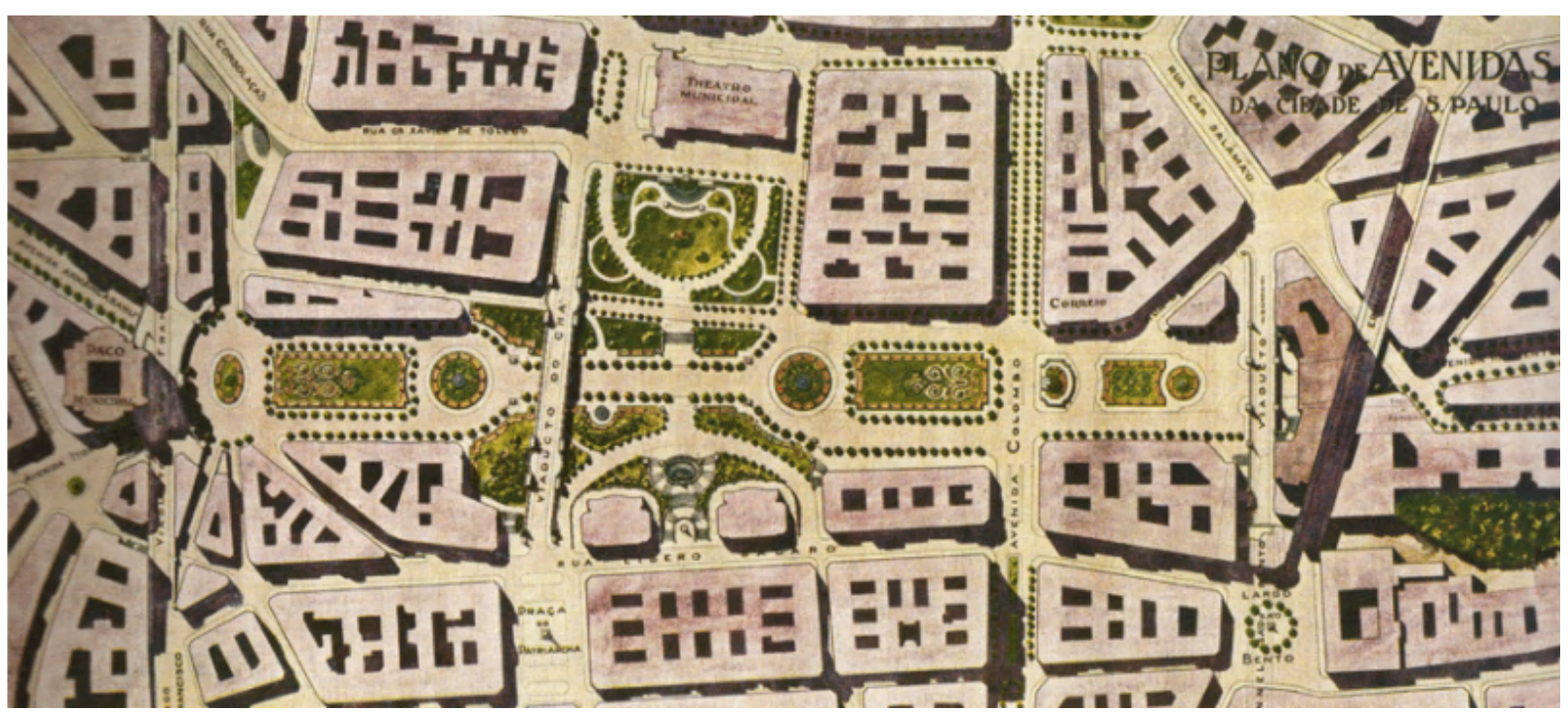

MAIA, F. P. Estudo de um Plano de Avenidas para cidade de São Paulo. São Paulo, Melhoramentos, 1930. in: TOLEDO, Prestes Maia e as origens do urbanismo moderno em São Paulo. São Paulo, Empresa das Artes, 1996, p.270

Em sua leitura do Plano de Avenidas, LEME (2000) descreve as propostas de criação de espaços públicos e conjuntos arquitetônicos - em pontos estratégicos na cidade - que se destacaram das demais propostas pela designação que receberam e por suas ilustrações aquareladas. Estes locais estratégicos e bastante valorizados foram escolhidos como símbolos dos anseios urbanísticos predominantes na sociedade paulistana dos anos 30, representando uma proposta estética para a cidade. Constituíram-se, por exemplo, pelos conjuntos de edifícios e praças que transformaram o Vale do Anhangabaú na sala de visitas de São Paulo e por uma nova estação ferroviária, às margens do Tietê, talvez como resposta ao projeto da Porta de entrada do Brasil, de Alfred Agache, no Rio de Janeiro. 
Figura 18 - Proposta para a Porta do Brasil

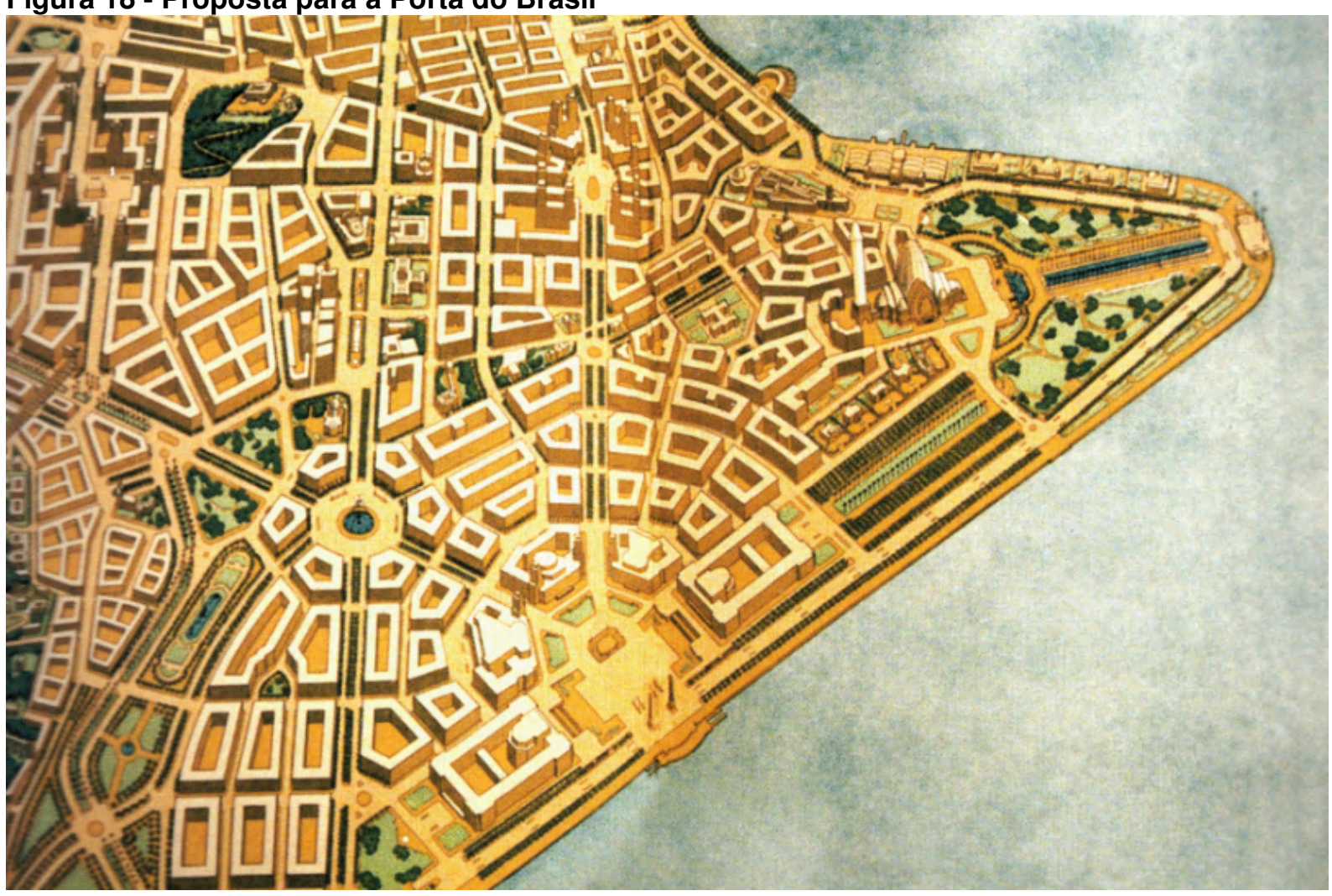

AGACHE, D. A. Proposta para a Porta de entrada do Brasil. Rio de Janeiro, 1930. in: TOLEDO, Prestes Maia e as origens do urbanismo moderno em São Paulo. São Paulo, Empresa das Artes, 1996, p.271

Segundo LEFÈVRE (1985), tangenciando a área do Centro Velho, o Vale do Anhangabaú constituia-se como um belíssimo parque, refletindo a preocupação existente com a caracterização da imagem de São Paulo que crescia. Transformações importantes foram realizadas por prefeitos como Fábio Prado e Prestes Maia, como o alargamento das vias que compõem o perímetro de irradiação, a construção do novo Viaduto do Chá, do Viaduto Jacareí, Viaduto Dona Paulina e Viaduto 9 de Julho, fomentando a integração entre o Centro Velho e o Centro Novo, bem como o adensamento e verticalização destas áreas.

Figura 19 - Vale do Anhangabaú - O Parque

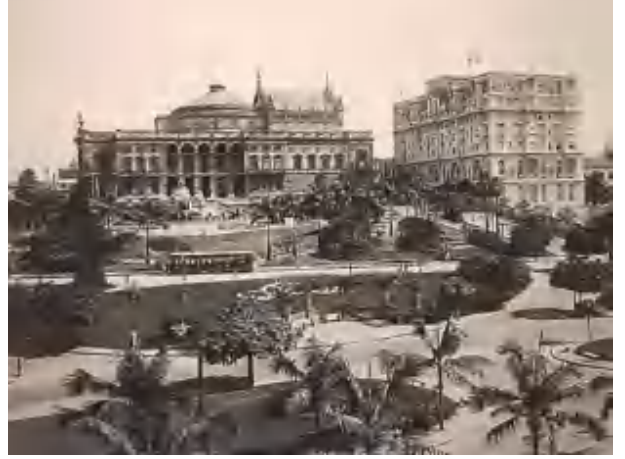


No entanto, o Plano de Avenidas propôs a reformulação do Parque do Anhangabaú e a sua integração com as avenidas radiais em direção ao sul da cidade - avenidas 9 de Julho e Itororó (atual avenida 23 de maio). O Parque do Vale do Anhangabaú deixou de existir com implantação progressiva das propostas do Plano de Avenidas e com a ligação do vale às avenidas que levavam aos bairros da zona norte da cidade. Hoje, o Vale do Anhangabaú compõe o importante eixo viário norte-sul de São Paulo, não podendo ser interrompido causar grandes empecilhos à circulação de veículos. Vale ressaltar que o Plano de Avenidas previa intervenções em todas as regiões da cidade, conforme esquema abaixo:

Figura 20 - Esquema teórico de São Paulo, em formas geométricas

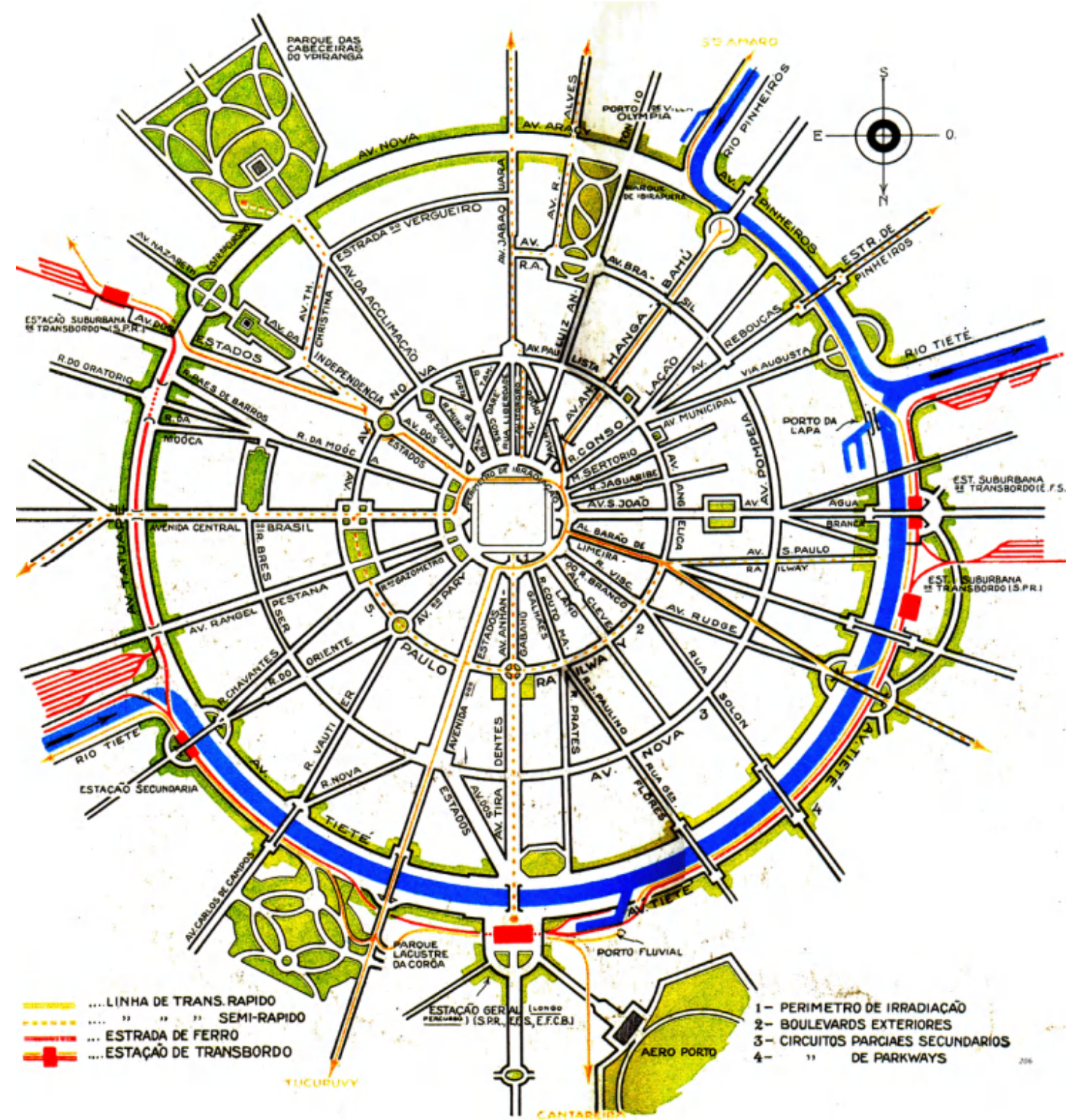

MAIA, F. P. Estudo de um Plano de Avenidas para cidade de São Paulo. São Paulo, Melhoramentos, 1930. in TOLEDO, 1996, p. 160. 
O sistema viário projetado no plano de 1930 compunha-se de três avenidas perimetrais articuladas por um sistema de avenidas radiais. $O$ sistema perimetral compunha-se de três anéis viários. O primeiro baseado nos bulevares parisienses o perímetro de irradiação - envolvia o Centro Velho, localizado no atual distrito Sé, e o Centro Novo, atual distrito República. A transposição do Vale do Anhangabaú naquele período, com a integração dos dois centros, foi de grande importância. $O$ comércio de primeira linha, as sedes de empresas e as atividades culturais já haviam se deslocado para o Centro Novo. As novas avenidas e os viadutos projetados sinalizaram a importância que esta área assumiria para a administração municipal. O segundo anel foi traçado em parte sobre o leito das ferrovias Sorocabana e São Paulo Railway, atravessando ao norte a região da Barra Funda e ao sul os bairros Higienópolis, Cerqueira César, Paraíso e Ipiranga. Seriam removidas para a Marginal do Rio Tietê as ferrovias, com o intuito de melhorar a circulação de veículos e unificar o serviço ferroviário, racionalizando-o. O terceiro anel, denominado como circuito de Parkways, compunha-se pelas marginais dos rios Tietê e Pinheiros, seguindo até o Ipiranga, descendo o Vale do Tamanduateí até a confluência com o Tietê. Foi reservada a margem direita deste rio para as ferrovias, com uma nova estação central. Na outra margem seriam localizadas as vias marginais, ligando os parques propostos para a cidade. Avenidas radiais, que saíam do perímetro de irradiação em direção a todos os quadrantes de São Paulo, interligaram os 3 anéis concêntricos. Baseada predominantemente em automóveis e ônibus, em relação a outros meios de transporte é evidente, o Plano de Avenidas configurou-se de forma radial-perimetral, permitindo a extensão da cidade sem limites, garantindo a integração entre os diversos bairros (LEME, 2000, p.71).

A saturação do sistema viário com veículos particulares foi a motivação para a realização do grande número de obras que alterou a fisionomia da cidade a partir dos anos 50 , em especial durante e logo após a gestão do prefeito Faria Lima, (1965 a 1969), com a abertura de diversas avenidas e implantação de vias expressas e elevados, como a Rua da Consolação, transformada em avenida, a Avenida 23 de Maio, a Avenida Rubem Berta, o Elevado Costa e Silva, a ligação leste-oeste e a Radial Leste, e com a execução de diversos complexos de obras feitas em função do sistema viário, como a Praça Roosevelt, o conjunto de obras no entroncamento das avenidas Paulista, Rebouças e Dr. Arnaldo, o conjunto de viadutos do Parque Dom Pedro II e muitas outras. (LEFÈVRE, 1985, p.95) 
A verticalização do centro, com a criação de arranha-céus no lugar dos prédios de pouca altura, resultou do forte desenvolvimento econômico e da adoção do modelo de centro único pelo planejamento urbano municipal. SOMEKH (1987) diz que as bases para a expansão vertical na cidade de São Paulo foram a implantação de novas e grandes avenidas, a alta valorização fundiária, a crise nos transportes, a legislação e o crescimento da atividade econômica. No conjunto, segundo REIS (1979), os novos tipos de edificação ocuparam os terrenos seguindo critérios das antigas habitações, tentando conciliar os velhos esquemas de implantação com as novas técnicas construtivas.

Entre 1946 e 1961, o Brasil passou por uma boa fase econômica, um grande momento de desenvolvimento para a economia brasileira. Entre 1948 e 1955, a produção industrial global teve um incremento de $87 \%$ em seu desempenho (SEGAWA, 1999, p. 161). Neste período, concluídas as avenidas do Perímetro de Irradiação do Plano de Avenidas, São Paulo era vista como cidade grande européia para alguns e norte-americana para outros - com seu passado provinciano deixado para trás. Porém, de acordo com Rino Levi ${ }^{4}$, a busca da imitação dos bulevares parisienses ou as preocupações focadas apenas no sistema viário de circulação levaram a cidade a manifestar sintomas de saturação. O aumento no número de veículos, associado à alta concentração demográfica em poucos pontos da cidade, refletia a deficiência da administração pública em gerenciar a cidade (ANELLI et al, 2001, p. 222).

Segundo ZMITROWICZ (1979), a legislação, de acordo com os códigos de parcelamento do solo urbano e com o zoneamento de seu uso e ocupação, exerce ação restritiva aos empreendimentos particulares, restringindo atividades de indivíduos em benefício do bem comum. No início da década de 1960, engenheiros e arquitetos tinham amadurecido as discussões e possíveis encaminhamentos legais para a regulamentação do uso e ocupação do solo paulistano. Porém, no centro da cidade, a malha urbana de vias e lotes já estava consolidada havia muitas décadas. $\mathrm{Na}$ consolidação das Leis de Zoneamento da cidade de São Paulo, com a Lei no

\footnotetext{
${ }^{4}$ Rino Levi estudou na Escola Alemã e no Instituto Médio Dante Alighieri em São Paulo. Em 1921 ingressou na Escola Preparatória e de Aplicação para os Arquitetos Civis em Milão, tendo se transferido em 1924 para a Escola Superior de Arquitetura de Roma, na qual se formou em 1926 (ANELLI, 2002, p.25).
} 
7.805/72, estabeleceram-se as zonas de: características residenciais (Z1 e Z2); subcentros de bairros (Z3 e Z4); área central (Z5) constituídas pelo centro da cidade e pela Avenida Paulista; características industriais (Z6); características especiais (Z8).

\begin{abstract}
A área entre o Vale do Anhangabaú e a Praça da República, conhecida como 'centro novo' e mais tudo o que fica para dentro do antigo 'perímetro de irradiação' e que corresponde à 'rótula' dos planos de circulação, é genericamente identificada como 'centro' em muitos estudos. Definições mais precisas do centro, como a obtida por Helena Kohn Cordeiro para o 'Núcleo'... ou a delimitação da Z5, caracterizada nas leis 7.805 de 1972 e 8.001 de $1973 \ldots$ abrangendo áreas aproximadamente equivalentes, englobando uma quantidade de quadras situadas imediatamente após a 'rótula' (LEFÈVRE, 1985, p.69).
\end{abstract}

\title{
Figura 21 - Caracterização do centro da cidade de São Paulo
}

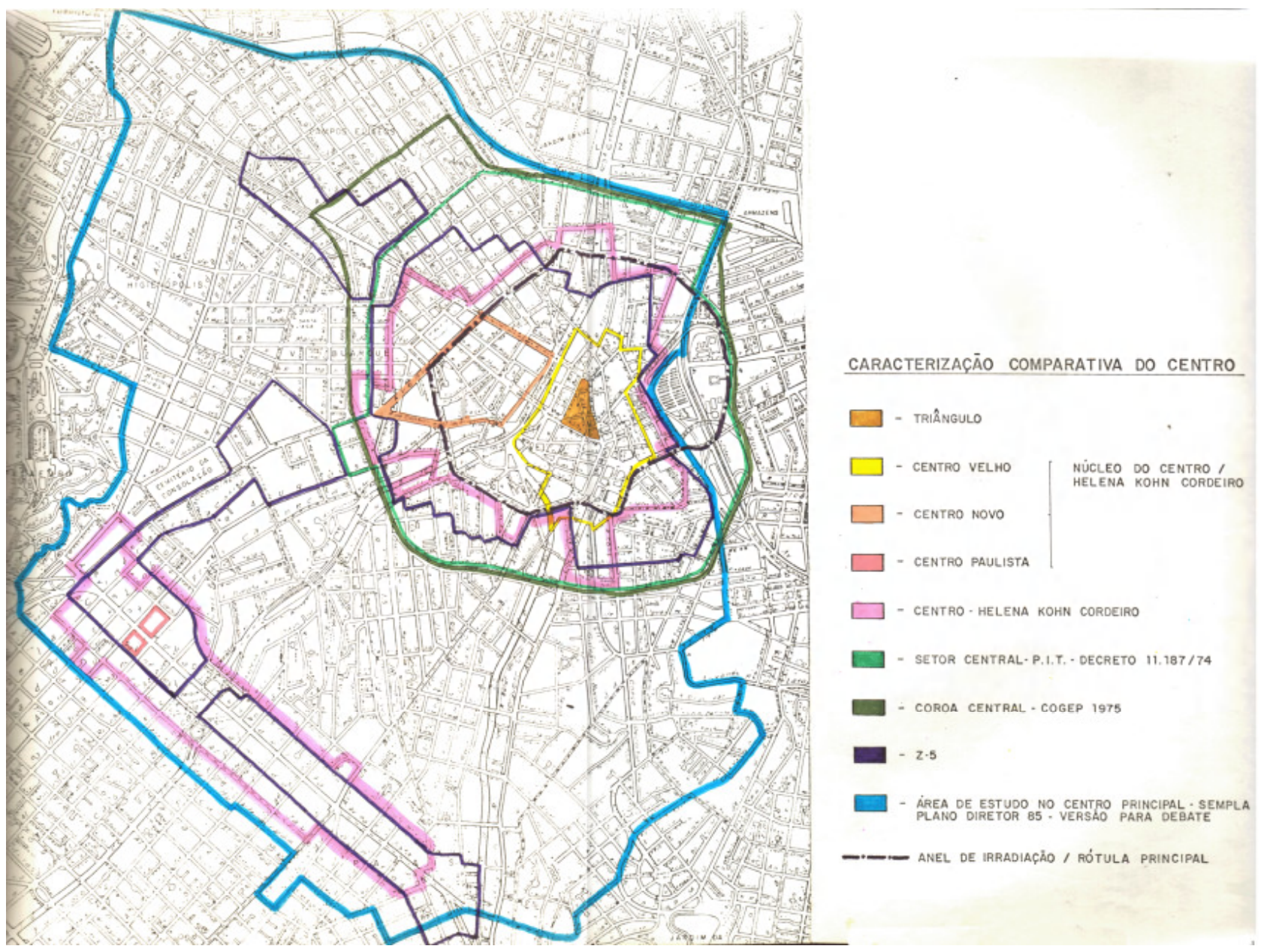

LEFÈVRE, José Eduardo de Assis. O transporte coletivo como agente transformador da estruturação do centro da cidade de São Paulo. 1986. 157 p. Dissertação (Mestrado) - Faculdade de Arquitetura e Urbanismo, Universidade de São Paulo, São Paulo, 1986. 
Figura 22 - Área Urbanizada, cidade de São Paulo - até 1974

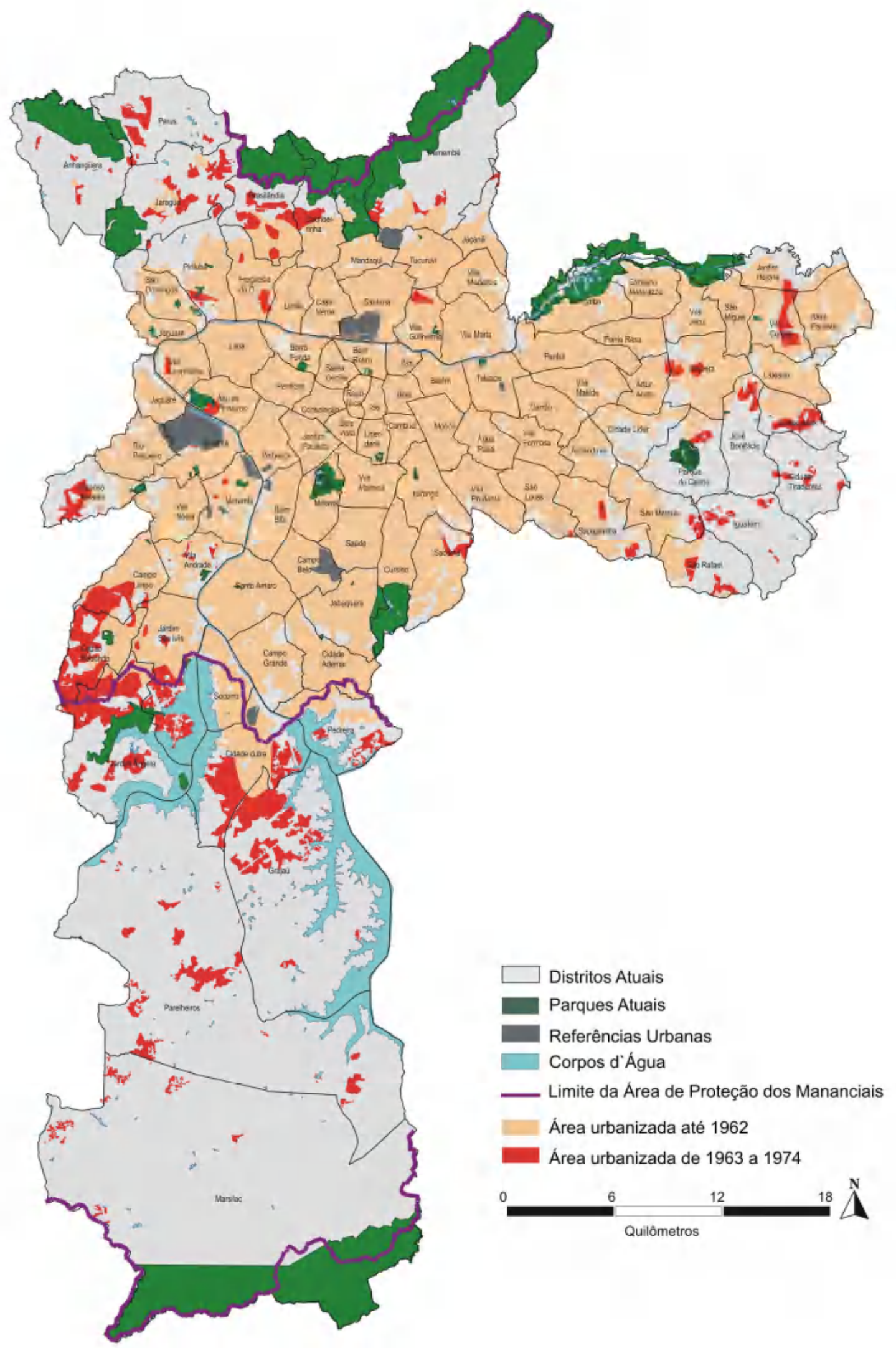

Emplasa. Mapa de Expansão da área Urbanizada da Região Metropolitana de São Paulo, 2002/2003. Adaptação Sempla/Dipro. 1 mapa, color. Escala Gráfica. Disponível em < http://sempla.prefeitura.sp.gov.br/historico/img/mapas/urb1872.jpg > Acesso em 05 ago. 2007. 
Definindo-se no capítulo anterior o século XX como recorte temporal de estudo, para determinar-se o perímetro físico a ser enfocado nesta pesquisa, partiu-se da análise de conceitos e fatos bastante trabalhados por autores como Maria Cristina Leme, José Eduardo Lefèvre, Witold Zmitrowicz, Cândido Campos Neto, Benedito de Toledo, Nestor Goulart Reis, Nadia Somekh e Regina Meyer. Como não se pretende uma pesquisa redundante, os trabalhos destes autores são o ponto de partida para a contextualização do cenário paulistano no século $X X$, quando da formulação da legislação urbana a ser exposta no capítulo 4.

Em função da relevância histórica do centro da cidade de São Paulo, região urbanizada e regulamentada desde fins do império, palco de inúmeras intervenções urbanas, definiu-se como "centro" a região caracterizada por CORDEIRO (1978) que corresponde ao "centro" definido no P.I.T. - Programa de Integração de Transportes, definido pelo decreto 11.187 de 1974: a área formada pelos atuais distritos Sé e República. Define-se, desta maneira, o perímetro a ser estudado na cidade de São Paulo, que será a base para o desenvolvimento da metodologia de pesquisa a ser detalhada no próximo capítulo. 


\section{3- METODOLOGIA DE PESQUISA}

Conforme definido no capítulo anterior, neste trabalho entende-se como "centro" da cidade de São Paulo o seguinte perímetro:

Avenida Duque de Caxias, Rua Mauá, avenidas do Estado e Mercúrio, Viadutos sobre o Rio Tamanduateí, Glicério, Leste-Oeste, Jaceguai, Júlio de Mesquita Filho, Avenida Radial Leste-Oeste, Praça Roosevelt, Rua Amaral Gurgel, Praça Alfredo Paulino e, novamente, Avenida Duque de Caxias, totalizando 8,09 km de extensão, com 459 ha de área.

Com base em levantamento feito sobre o Mapa Oficial da Cidade (MOC) / Cadastro de Logradouros do Município de São Paulo, que contêm a configuração atual de quadras e vias da cidade, desconsiderando-se as praças e demais áreas públicas não edificadas, a área das quadras corresponde a aproximadamente 260 hectares dentro do perímetro estudado. Isto é, somando-se apenas as áreas dos lotes, privados e de propriedade pública, tem-se $56,43 \%$ do perímetro estudado como área edificada ou passível de edificação.

Atualmente, de acordo com dados da Prefeitura Municipal de São Paulo (fonte: <http://www2.prefeitura.sp.gov.br/subprefeituras/spse> Acesso em: 20 fev. 2008), a densidade populacional média no perímetro estudado é de aproximadamente:

- 45 hab/ha no distrito Sé.

- 89 hab/ha no distrito República.

- 69 hab/ha considerando-se ambos os distritos. 
Figura 23 - Perímetro de estudo: "centro" da cidade de São Paulo

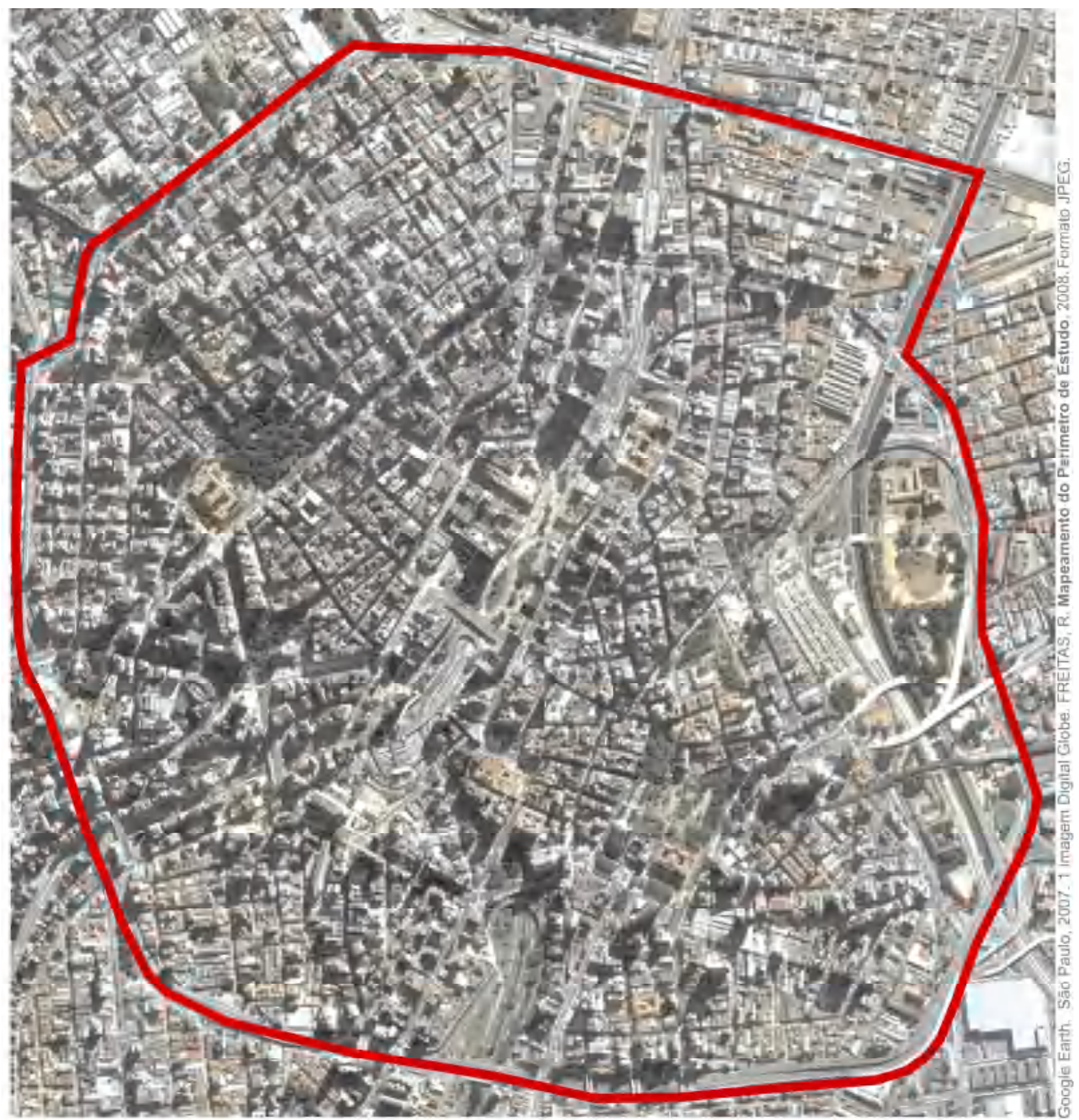

Escala gráfica

0

$500 \mathrm{~m}$

$1.000 \mathrm{~m}$

Perimetro de Estudo

Partindo-se de um recorte temporal e físico, interpretaram-se cronologicamente fatos relacionados ao objeto de estudo, para posterior validação das interpretações, verificando-se decorrências dos fatos. Ou seja, interpretaram-se graficamente as leis urbanas (fatos), que no século XX regulamentaram a ocupação urbana em lotes particulares no "centro" paulistano (objeto). Desta maneira, foi possível a verificação da aplicação ou não destas leis, por comparação entre as interpretações gráficas (no 
capítulo 4) e a paisagem urbana resultante das construções privadas, nas principais vias do "centro" da cidade de São Paulo (no capítulo 5 e anexo 1).

Esta pesquisa desenvolveu-se com base nos arquivos da Biblioteca Nacional do Rio de Janeiro, da Referência Legislativa Municipal de São Paulo, Biblioteca da FAUUSP, DPH/SP, Biblioteca da EPUSP/PCC, IGC/SP e Biblioteca da Faculdade de Direito-USP.

Foram estudadas 60 obras construídas ao longo do século $\mathrm{XX}$ dentro do perímetro de estudo, dentre as quais se encontraram 30 projetos disponíveis para pesquisa, cuja análise permitiu a constatação de semelhanças quanto aos critérios de implantação destas obras, em função da aplicação da legislação urbana. Deste modo, os projetos estudados foram referência - enquanto vocabulário iconográfico para a interpretação gráfica das leis urbanas paulistanas, que regulamentaram os lotes privados nos atuais distritos Sé e República, ao longo do século XX. Por outro lado, a leitura das referidas leis possibilitou a análise das obras construídas em lotes privados em função de sua adequação ou não às regulamentações urbanas. Este processo não foi linear, constituindo-se de análises complementares.

Como esta dissertação é também entendida como meio de tornar públicas informações de apoio para futuros trabalhos, como pesquisas específicas a respeito do desenvolvimento e apresentação dos projetos de edifícios, decidiu-se publicar 10 exemplares escolhidos dentro do conjunto de projetos e de obras estudadas. A escolha destes exemplos ocorreu em função dos seguintes critérios:

- do período, intervalo "médio" de 10 anos entre uma construção e outra, não caracterizando uma amostragem estatística, mas apenas exemplificando a maneira pela qual se construiu no "centro" ao longo do século passado;

- da coerência de informações entre a obra e o projeto;

- da implantação no lote, exemplificando características construtivas decorrentes da aplicação da legislação urbana, recorrentes dentre as obras estudadas;

- da localização dentro do perímetro estudado, em vias que tenham sido citadas e regulamentadas por leis desde o fim do século XIX. 
Como o processo de entendimento das leis e das obras não foi linear, em busca de facilitar o entendimento das informações obtidas, será exposta no capítulo 4 a relação da legislação urbana paulistana em ordem cronológica e, no anexo 1, a análise das 10 construções e projetos escolhidos, em função da aplicação ou não das leis urbanas. Para melhor visualização dos resultados esperados quando da criação das regulamentações urbanas, foram desenvolvidos croquis ilustrativos do espaço privado construído (hipotético) que resultaria da aplicação da legislação urbana estudada. Os desenhos resultantes desta interpretação serão expostos no capítulo 4, no qual foram também incluídas as interpretações gráficas já existentes do Código de Edificações de 1975 e do Novo Código de Obras e Edificações de 1992, que substituiu o de 1975 e vigora até hoje, 2008.

Para que se tenha uma visão de conjunto, serão descritas as leis urbanas no próximo capítulo, na seqüência de sua criação. Incluíram-se algumas leis estaduais e federais que foram consideradas quando da ocupação urbana do "centro" paulistano, apesar de não se constituírem como legislação urbana especificamente por exemplo, o Decreto Federal no 5.481, de 1928, que regulamentou a copropriedade de imóveis por apartamentos.

Não foram incluídas no capítulo a seguir as leis de combate a incêndio do século XX. Constatou-se que sua relação com a caracterização da paisagem urbana paulistana não é significativa quando se analisa o espaço edificado no período estudado. A primeira especificação do Corpo de Bombeiros anexa a um decreto surgiu em 1983. Dez anos mais tarde, após o Decreto Estadual 38.069 de 1993, passou-se a aprovar a instalação e o dimensionamento dos equipamentos de proteção contra incêndio. Estas regulamentações pouco definiram a paisagem urbana paulistana do século $\mathrm{XX}$, a não ser pelas escadas externas para rotas de emergência, que podem ser vistas em alguns prédios. Verificaram-se exigências internas para os edifícios que seriam construídos a partir de 1983, em função de seu uso, de seus materiais construtivos e dos critérios técnicos para a disposição das instalações de combate a incêndio dentro das edificações. Estas regulamentações específicas poderiam ser analisadas em um futuro trabalho que tratasse mais detalhadamente da configuração dos espaços internos, dos materiais construtivos, das instalações hidráulicas e elétricas em edificações. 
Em 1923 criou-se a primeira lei de arruamento com visão urbanística, Lei no 2.611. Em 1929 definiram-se restrições especiais para bairros a sudoeste da cidade com a Lei no 3.427. Verificou-se que a legislação urbanística da cidade de São Paulo, consolidada em 1972 pela Lei no 7.805, começou a se fazer presente na legislação edilícia de maneira sutil no início do século XX.

Visando validar a interpretação gráfica da legislação, foram registradas imagens atuais das vias centrais da cidade, que no período de 1901 a 2000, caracterizaramse em função das regulamentações de edifícios particulares, obedecendo a restrições e exigências legais específicas. A exposição destas imagens inclui-se no capítulo 5, em conjunto com mapeamentos das leis, a fim de permitir a visualização em planta das áreas centrais específicas abrangidas pela legislação ao longo do século $X X$.

Utilizando-se a cartografia disponível, a documentação fotográfica das principais vias da área em estudo, o levantamento e análise de alguns edifícios, buscou-se validar e responder aos questionamentos formulados na introdução:

- A legislação urbana configurou a paisagem da cidade de São Paulo? No caso da resposta a este primeiro questionamento ser afirmativa: qual a evidência mais relevante desta caracterização da paisagem urbana no "centro" da cidade de São Paulo, no século XX?

- Há relação no sentido inverso, isto é, revisaram-se ou criaram-se leis a partir de obras edificadas em desacordo com a legislação vigente em determinado período do século $X X$ ? 


\section{4- AS LEIS E O CENTRO DA CIDADE DE SÃO PAULO}

Será cronologicamente exposta neste capítulo a legislação municipal que regulamentou as construções em lotes particulares na cidade de São Paulo no século $\mathrm{XX}$, sendo incluída também a legislação estadual e federal de mesmo caráter. Quando não se tratar da legislação municipal, será indicada a esfera de poder que a estatuiu (estadual ou federal). Vale ressaltar que as leis serão ilustradas por croquis, que representam o resultado hipotético da aplicação legal ao lote particular. A fonte destas leis interpretadas graficamente encontra-se detalhada no capítulo 7 - Referências.

De acordo com MONTORO (1989), a lei jurídica constitui-se por preceitos de conduta, impostos coercitivamente pela autoridade governamental. Em sentido amplo, emprega-se a palavra lei ou legislação para indicar quaisquer normas jurídicas escritas, oriundas do Poder Legislativo como decretos, decretos-leis ou outras normas baixadas pelo Poder Executivo. Ainda segundo este autor, entendese que o costume jurídico apresenta-se como verdadeira norma jurídica, cuja principal característica é ser criada espontaneamente em função de hábitos sociais. Neste trabalho, no que diz respeito ao costume jurídico, serão expostas normas ligadas ao Direito administrativo. Ou seja, normas jurídicas construídas em função do costume, da reiteração dos casos e da praxe administrativa.

Para MIRANDA (1996), hoje, nem sempre se consegue delimitar com nitidez as fronteiras do Direito constitucional e do Direito administrativo. Este último compreende não só as normas reguladoras da estrutura e disciplina interna da administração pública, mas também as regras de atuação de seus elementos como sujeitos de direitos, no exercício dos seus poderes e no cumprimento dos seus deveres legais para com os administrados. O princípio da legalidade da administração pressupõe o da constitucionalidade da lei. 
Como o número de classificações das normas jurídicas é bastante extenso, seguemse as classificações que se referem diretamente à lei e que são pertinentes a esta pesquisa. Segundo MONTORO (1989):

a) Quanto à hierarquia no ordenamento jurídico: decretos legislativos são normas aprovadas pelo Congresso sobre a matéria de sua exclusiva competência; normas regulamentares são regras jurídicas gerais, abstratas e impessoais, estabelecidas pelo Poder Executivo, em desenvolvimento da lei; decretos-lei vigoraram como prerrogativa do Poder Executivo até a promulgação da Constituição Federal de 1988, que em seu lugar introduziu a medida provisória. Tratava-se de uma figura híbrida: o decreto é ato do Poder Executivo; a lei é tarefa do Poder Legislativo, especificamente. O Decreto-lei era uma lei editada pelo Poder Executivo;

b) Quanto à sistematização: Leis esparsas são as editadas isoladamente; códigos constituem um corpo orgânico de normas sobre determinado campo do direito; Consolidação reúne de modo sistemático leis esparsas já existentes e em vigor, sobre determinada matéria;

c) Quanto à esfera do poder público, cuja competência normativa está fixada pela Constituição Federal: são Leis Federais a Constituição Federal e suas Leis Complementares, as Leis, Códigos, Medidas Provisórias e Decretos Federais, editados pela União ou qualquer de seus órgãos; são Leis Estaduais a Constituição dos Estados e respectivas Leis Complementares, as Leis, Códigos e Decretos Estaduais; são Leis Municipais as Leis Orgânicas dos Municípios, Leis Municipais, Decretos, Posturas e demais normas estatuídas pelos órgãos municipais.

Baseando-se em conceitos apresentados por autores como MONTORO (1989), MIRANDA (1996) e FERREIRA FILHO (2002), entende-se que no período colonial a lei era o verdadeiro soberano, sobrepondo-se ao monarca, sendo o Rei feito pela lei. No período medieval não apenas à lei divina estava subordinado o Rei, mas também aos hábitos, à lei oral e imemorial, decorrente das práticas seguidas pela comunidade sob seu governo. Em Portugal, desde Afonso Henriques até o fim do período medieval a concepção que se fazia do Direito e da lei não era diferente da que predominava no restante da Europa Ocidental. Prevalecia, quase que 
absolutamente, a idéia de que o soberano estava adstrito à lei, subordinado à lei natural, ao costume e à lei escrita. Ao editar as ordenações, o Rei de Portugal não se apresentava como legislador, mas como consolidador do direito já vigente. Vale ressaltar que a necessidade de ouvir o povo fortalecia em boa parte as cortes, que apesar de seu caráter consultivo, não poderiam ser deixadas de lado em matéria de leis. Esse espírito está presente nas Ordenações Manuelinas de 1521, que incluíram leis esparsas - as leis extravagantes - ao revisarem as Ordenações Afonsinas de 1446, que por sua vez eram decorrência da Lei das Sete Partidas, traduzida do espanhol para o português na segunda metade do século XIII, a mando de Dom Dinis.

Portugal de Afonso Henriques, até 1221, foi governado por leis esparsas, ano em que, sob Afonso II, as cortes de Coimbra decretaram leis gerais para todo o Reino. De 1290 até 1446 foi traduzida a Lei das Sete Partidas, que inspirada no romanismo e no direito canônico tivera sua representação mais importante no código de Afonso X, o sábio, de Aragão, Castela e Leão (1252 a 1284). Tornou-se conhecida como Ordenações Afonsinas... Considerada pelos historiadores como o primeiro código de leis organizado na Europa posteriormente às codificações romanas. O Código Afonsino introduz o sistema de representação indireta do povo através dos vereadores que substituíram os "homens-bons" das antigas assembléias (ANDRADE, 1966, p.22).

No período colonial brasileiro as Cartas de Lei e Leis eram normas de caráter geral, ações cumpridas de acordo com as intenções do Rei, sempre com sua assinatura. Àquela época, decretos referiam-se a determinado indivíduo, contendo uma providência específica ou geral e de certa permanência, sendo apenas rubricadas pelo Rei. De origem romana, a constituição zenoniana: código justiniano VIII, de 490 D.C., fez-se presente nas ordenações, com vigência em Portugal e no Brasil, até o ano de 1750, sob Pombal. Do ponto de vista da regulação do espaço edificado em regiões com aglomerações humanas, suas principais normas fixavam as alturas, as distâncias e o alinhamento das edificações, determinando larguras de vias e servidões de ar, luz e vista.

As Ordenações Filipinas, que repetiram e atualizaram as Ordenações Manuelinas, fundamentaram o processo de urbanização do Brasil. Decretadas em 1603, no reinado de Filipe II - terceiro de Espanha, investido soberano de Portugal - 
obrigavam a deixar entre prédios vizinhos na época imperial 1,375 metros de largura mínima das vielas e azinhagas. Entre prédios vizinhos, não separados por vielas ou azinhagas, faixas de servidão de distância mínima igual a 0,44 metros entre os pontos onde caíssem as águas do telhado. Ainda de acordo com ANDRADE (1966), as clássicas servidões do direito romano foram discutidas, não sendo aceitas por nenhum dos dois jurisconsultos, Lobão e Moura, dois dos mais conhecidos e mais constantemente citados em questões de pareceres jurídicos da época colonial, referentes a construção:

O espaço livre entre duas edificações fundado em três razões: primeira, para evitar a passagem do fogo, em caso de incêndio, segunda para permitir a passagem entre os dois edifícios e terceira para assegurar o escoamento de águas pluviais e evitar questões sobre beirais dos telhados. Moura justifica a rejeição da seguinte maneira: 'mas o tempo assaz previu essa inconsideração, porque tais interstícios, além de causarem uma notável deformidade na cidade, bem depressa se tornaram lugares de frequentíssimos e imoralíssimos vícios com escândalo e ofensa da moralidade das pessoas que transitavam pelas ruas; servidão também de receptáculo de imundície e de latrinas públicas, as quais com suas exalações de pestilentes miasmas infeccionarão logo toda a cidade e arruinarão a saúde pública, pelo que foi semelhante interstício considerado não somente contra os bons costumes, mas ainda como ridículo.' Ridículo, na acepção latina de absurdo.

Para Lobão, podia-se edificar 'pelos lados de outras casas, sem necessidade de deixar interstício algum e mesmo arrumada a parede dos vizinhos, o que longe de the ser prejudicial, a sustenta e fortifica mais' (ANDRADE, 1966, p.165).

LEME (2000) relata que, em todos os países, o ensino do urbanismo surgiu após a prática urbanística, a fim de legitimá-la. Entende-se assim que, na falta de técnicos formados para lidar com as questões urbanas, homens versados em leis (como os jurisconsultos citados supra), não habilitados às técnicas da construção civil, emitiam pareceres e encaminhavam definitivamente resoluções de conflitos urbanos. Suas argumentações sustentavam-se com base em critérios supostamente estruturais e estéticos, sendo estes últimos referenciados em localidades urbanas já consolidadas na Europa. O ensino de urbanismo constituiu-se a partir das experiências de intervenção na cidade, a partir de projetos de abertura e extensão viária, do saneamento urbano e da legislação - por meio da presença de indivíduos como os citados acima. 
No Brasil, de acordo com LEME (2000), o urbanismo enquanto disciplina acadêmica iniciou-se nos cursos de Engenharia e o seu conteúdo reforçou o trabalho profissional dos engenheiros e engenheiros-arquitetos no início do século $X X$. Na Escola Politécnica, em São Paulo, passou a ser lecionado apenas ao final da década de 1920, consolidando-se efetivamente após a década de 1950, já integrando os currículos das Faculdades de Arquitetura. Apesar da consolidação tardia do urbanismo como disciplina de graduação, os engenheiros e engenheiros arquitetos formados no Brasil a partir do início do século $\mathrm{XX}$ assumiram, em diversos momentos, funções profissionais pelas quais lhes foi atribuída a responsabilidade de regulamentar a cidade de São Paulo, pela criação e pela aplicação de leis urbanas.

$\mathrm{Na}$ França, até o século XIX, a legislação obrigava o proprietário a obter alinhamento, mas não a obter licença de construção. LEFEVRE (1951) diz que a licença de construção foi introduzida na legislação francesa pelo Decreto-Lei de 26 de março de 1852, aplicável às ruas de Paris e extensivo a outras cidades mediante solicitação. Já a legislação urbana americana, a partir de 1867 desenvolveu-se, de modo tímido, com a adoção de regras para a melhoria da ventilação e iluminação nas casas coletivas, assim como para a definição da altura máxima dos edifícios. Estas regulamentações urbanas norte-americanas foram modeladas na de Nova lorque, por sua vez orientada no sentido da segurança das edificações, principalmente quanto à prevenção de incêndios.

A partir de 06 de outubro de 1886, ainda sob o império português, com o Código de Posturas do Município de São Paulo definiram-se largura mínima das ruas: 16 metros; largura mínima para as avenidas: 25 metros; altura dos edifícios no alinhamento: primeiro pavimento 5 metros, segundo 4,88 metros, terceiro 4,56 metros; altura máxima do prédio: 17 metros; portas: 1,30 x 3,20 metros; janelas 1,10 x 2,20 metros; soalho: 0,50 metros acima do nível do terreno; saliências: 0,15 metros no embasamento, 0,30 metros para as sacadas do primeiro pavimento, 1,00 metro nos balcões do segundo pavimento, 1,80 metros em balcões do terceiro pavimento, 0,15 metros para as cornijas. Dimensões mínimas para cortiços - frente: 15,00 metros; separação entre fileiras de casas: 5,00 metros; portas e janelas 0,90 a 1,00 x 1,80 a 2,00 metros; soalho: 0,20 metros acima do nível do terreno; peça (unidade) mínima: $5 \mathrm{~m}^{2}$. 
Figura 24 - Código de Posturas do Município de São Paulo 06/10/1886
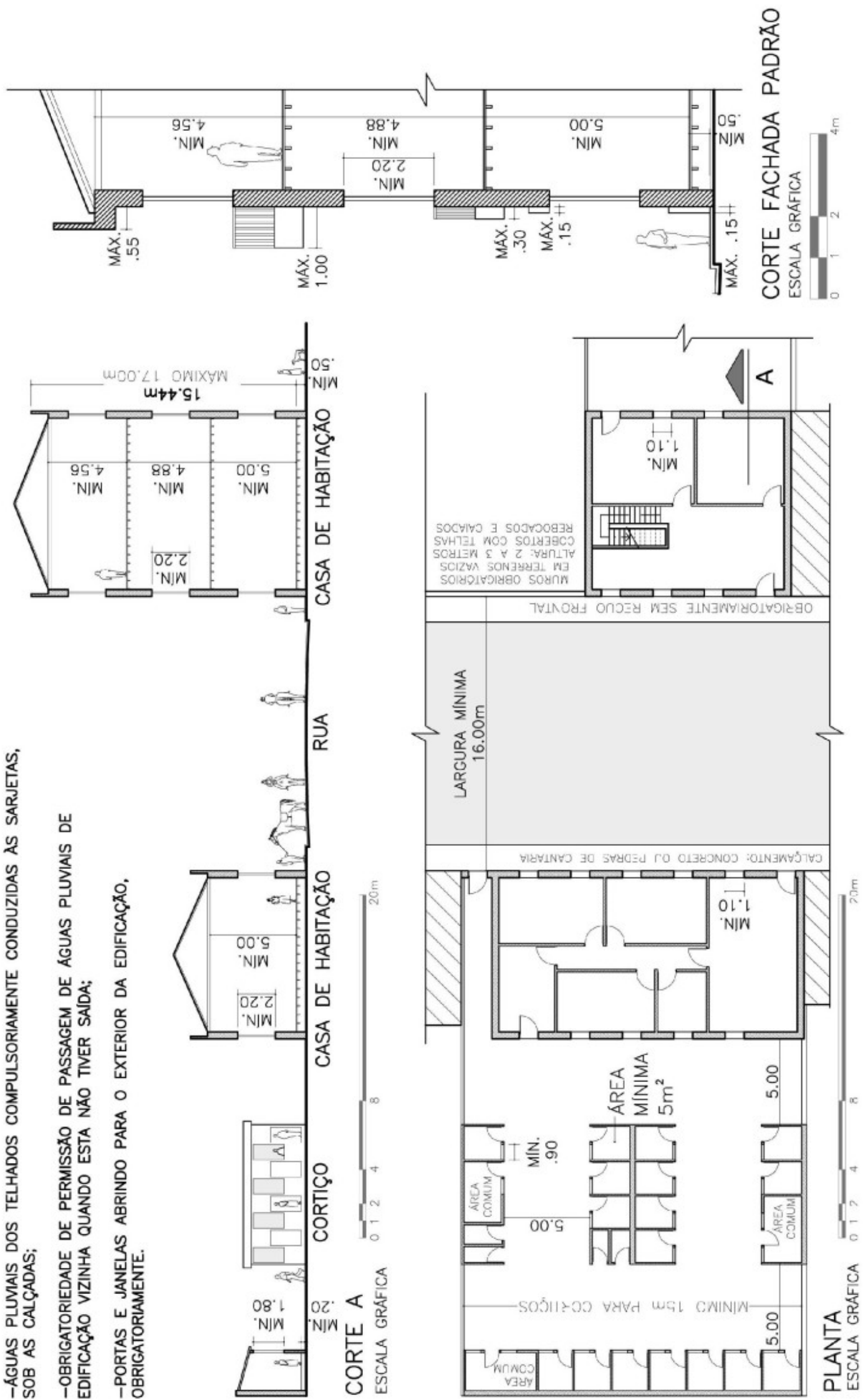
De acordo com ROLNIK (2003), a primeira preocupação da legislação municipal após a proclamação da República, foi redesenhar as ruas e eliminar cortiços do centro da cidade, de acordo com os Planos de Melhoramentos da Capital. Porém, apesar das resoluções para a construção de uma nova imagem ordenada e limpa da cidade, ainda nos grandes e ricos sobrados a maior parte dos dormitórios não tinha janelas ou aberturas para o exterior, não tendo sido estabelecidas exigências de iluminação e ventilação para esses aposentos. Segundo REIS (1970), o desaparecimento das alcovas só ocorreu em pleno século XX. Não diferente de Nova lorque, onde em 1915, já com uma população da ordem de 5 milhões de habitantes, existiam cerca de 80.000 moradias com quartos sem janelas (LEFEVRE, 1951, p.17).

Em 1891, data da primeira constituição republicana brasileira, que adaptou ao Brasil o sistema constitucional de modelo norte-americano, foi reorganizado o poder, distribuído entre a União e os Estados Federados e substituiu-se à tendência parlamentar um princípio de governo presidencial (MIRANDA, 1996, p. 226). Neste mesmo ano, as Leis Estaduais no 16 e $n^{\circ} 21$ restabeleceram o regime eleitoral e foi eleita uma nova Câmara Municipal em São Paulo. Dois anos depois, a Lei Estadual no 191/93 estabeleceu o primeiro regulamento da Escola Politécnica.

\footnotetext{
As fundações das escolas politécnica do Rio e de São Paulo, e mais a renovação da faculdade de medicina do Rio, revivesceram o meio técnico e colocaram, em poucos anos, grande número de médicos e engenheiros, de formação brasileira, em atividade entusiástica na batalha do desenvolvimento nacional. A velha fórmula do poder moderador não mais satisfazia a ânsia de progresso; do debate das idéias passou-se à ação violenta, oportuna e ininterrupta, que a transladação da economia rural para a urbana exigia e provocava, pondo abaixo, por fim, a estrutura imperial (ANDRADE, 1966, p.255).
}

Em 1893, com a Lei no. 38, foram definidos critérios técnicos para as construções, que deveriam ter paredes principais com espessura mínima de 0,30 metros no pavimento mais alto. A partir desta dimensão mínima, seriam adicionados 0,15 metros na espessura de tais paredes, a cada um dos pavimentos abaixo do superior. Naquele ano, as plantas para novas edificações passariam obrigatoriamente pela Intendência Municipal para aprovação, devendo ser compulsoriamente iluminados e arejados os dormitórios nas residências. A Lei no 38/93, além de definir largura 
mínima de 16 metros para as novas ruas, estabeleceu que jardins e praças públicas seriam implantados em proporções quadradas. Em 1894, baseado na legislação sanitária francesa da higiene residencial, foi criado o Código Sanitário do Estado de São Paulo, Decreto Estadual no 233.

A obrigatoriedade do respeito ao padrão de construções estabelecido pelo Código de Posturas do Município de 1886 e pelo Código Sanitário Estadual de 1894 foi reforçada pela Lei ํำ220, em 1896, que previa a demolição de qualquer edifício fora do padrão municipal. No mesmo ano, a Lei no 274 regulamentava a altura mínima de 2,20 metros, a partir do passeio, para a instalação de toldos nas fachadas dos edifícios, evidenciando a preocupação com os critérios pelos quais seriam compostas as fachadas dos edifícios.

O cargo de prefeito, a ser exercido por um vereador, foi criado em 1898, pela Lei $\mathrm{n}^{0}$ 374. Os serviços municipais foram então divididos em quatro seções, sendo uma delas a Seção de Obras. Trinta e nove dias depois era empossado Antonio da Silva Prado, em 7 de janeiro de 1899, o primeiro prefeito de São Paulo. No início de seu mandato buscou-se resolver a questão de ventilação e iluminação das construções, com a lei no 498 de 1900, cujo artigo 1ํoxigia área mínima de $10 \mathrm{~m}^{2}$, interna ao lote, com lado mínimo de 2 metros, para a qual os compartimentos internos da construção teriam aberturas, na proporção de $20 \%$ da área do ambiente. Quanto aos critérios técnico-construtivos, passou-se a exigir a espessura mínima de 0,45 metros nas fundações, aumentando-se 0,15 metros nesta espessura de modo a seguir a regra estabelecida pela Lei ํㅡ 38 de 1893.

Em 1904, com a Lei $\mathrm{n}^{\circ}$ 761, o poder municipal estabeleceu incentivos fiscais aos proprietários que, até 1906, construíssem edifícios de acordo com o Padrão de Fachada da Prefeitura de São Paulo, nas ruas Barão de Itapetininga e Conselheiro Crispiniano. A Lei no 1.011, de 1907, trouxe novos incentivos fiscais aos proprietários, que até 1909 construíssem edifícios com mais de dois pavimentos, adotando fachadas aprovadas pela Prefeitura, às ruas São Bento, Quinze de Novembro, Direita, Álvares Penteado, Quitanda, Boa Vista, Tesouro, Anchieta, Marechal Deodoro, Esperança, Quartel, Quintino Bocayuva, Fundição, Carmo, Barão de Itapetininga, Conselheiro Crispiniano, Vinte e Quatro de Maio; Largo do 
Tesouro, Misericórdia, Sé, São Bento, São Francisco, Palácio, Carmo, República, Paissandu; Praças João Mendes e Antonio Prado.

Figura 25 - Código Sanitário do Estado de São Paulo 02/03/1894
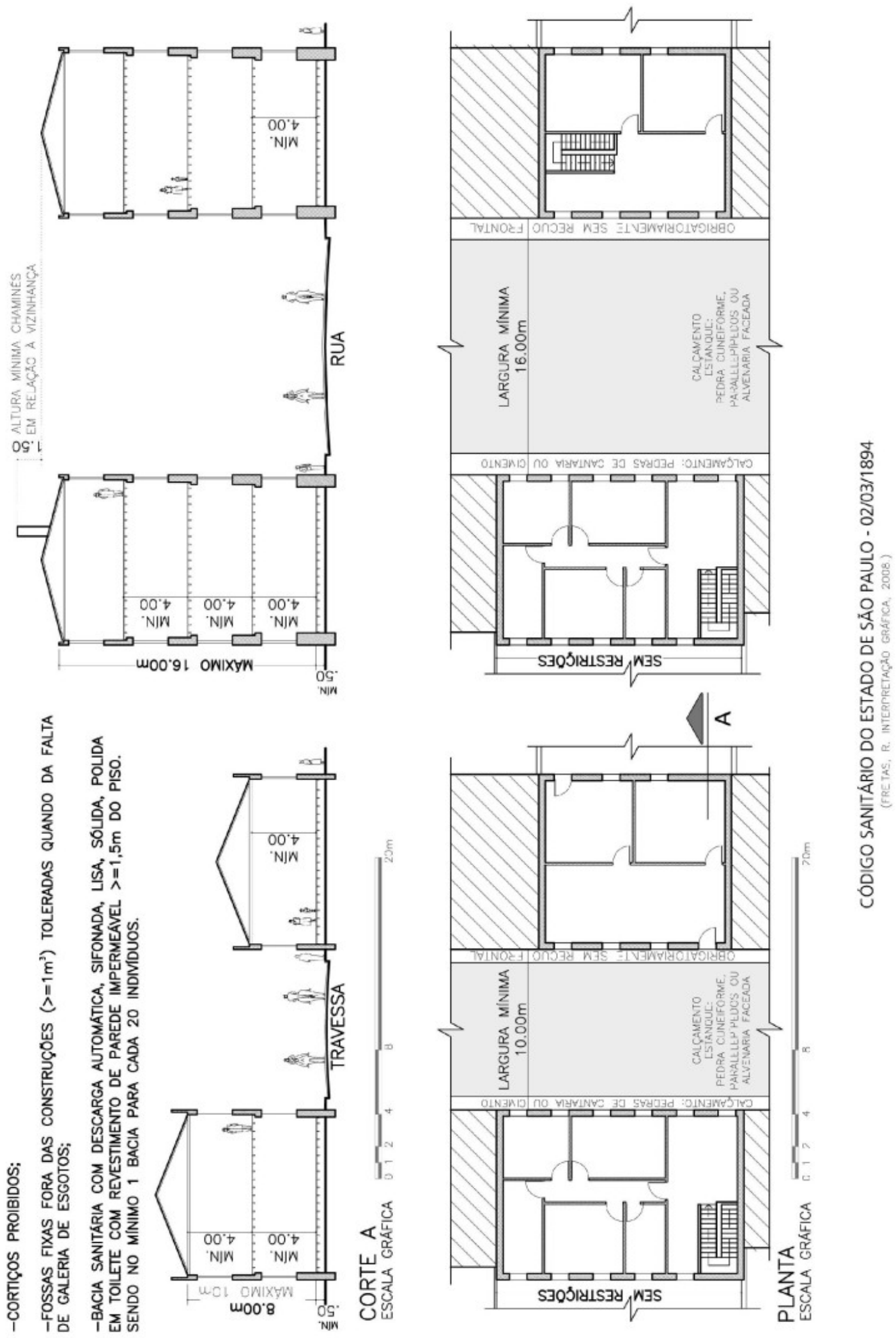
Figura 26 - Código Sanitário do Estado de São Paulo 02/03/1894
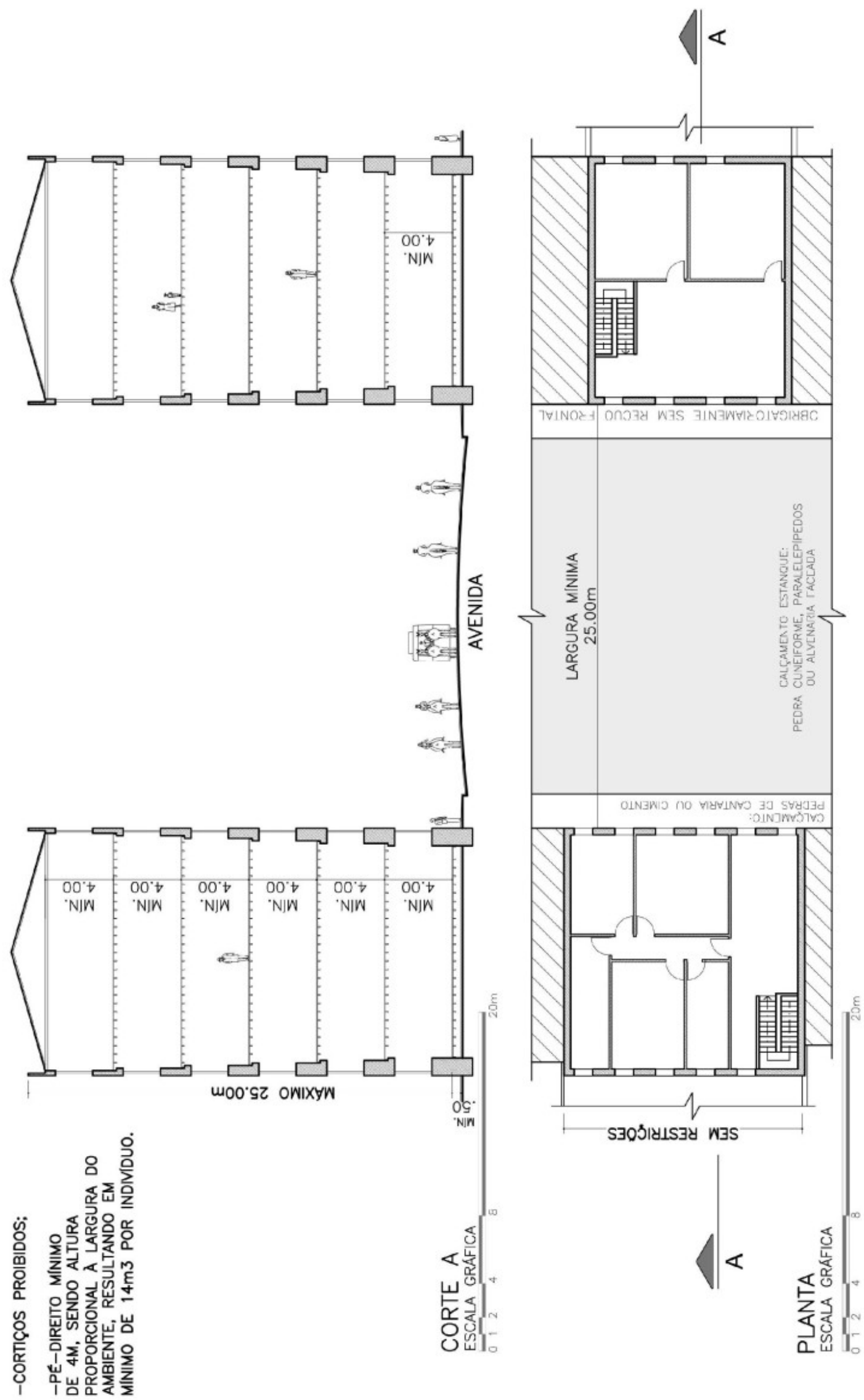
Figura 27 - Lei no 498 de 1900
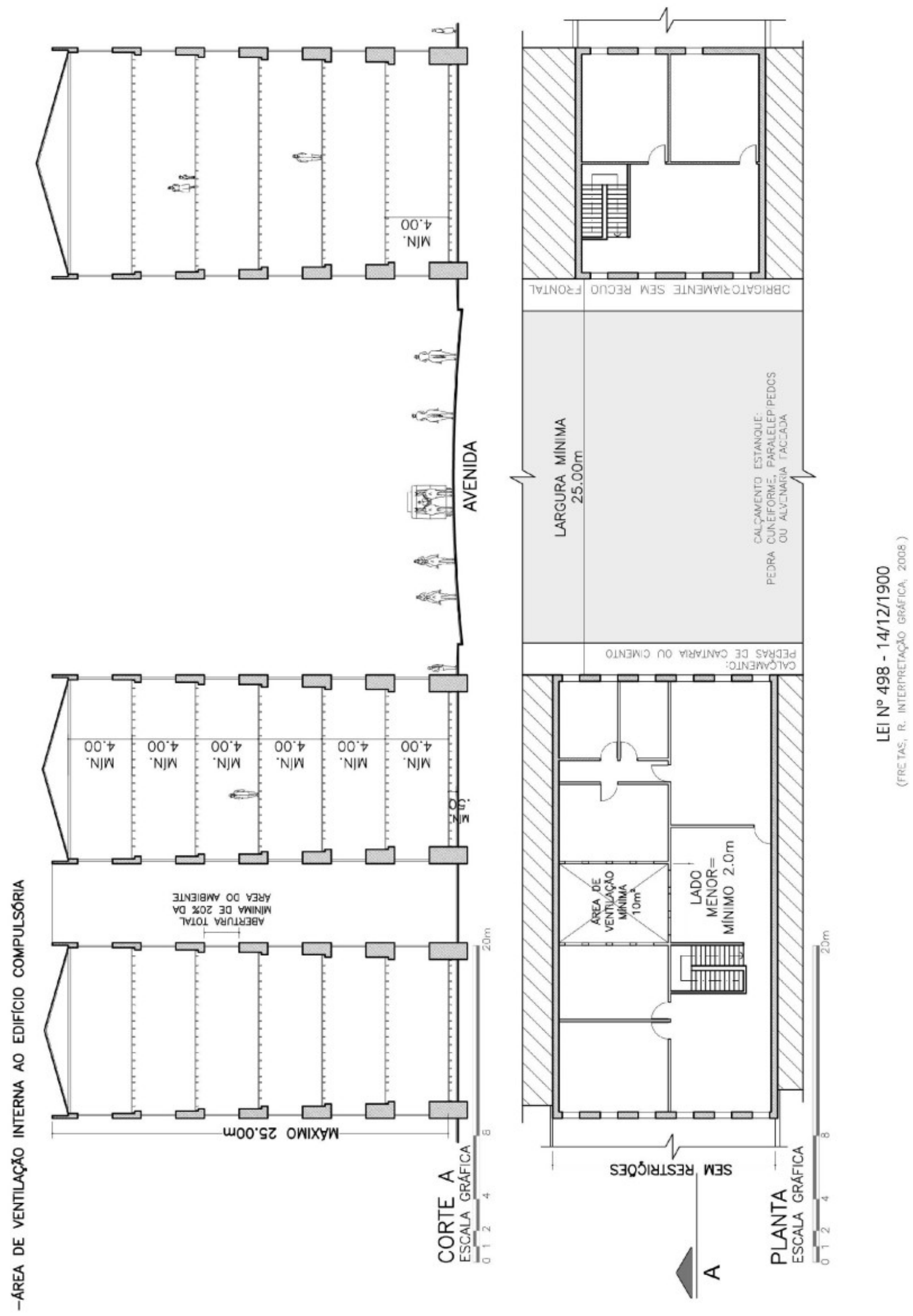
Em 1912, a Lei no 1.585, em seu artigo 5ํㅜㄹ definira critérios de fachadas mais rigorosos: as linhas mestras arquitetônicas horizontais deveriam ser obedecidas em edificações contíguas, partindo-se da construção no ponto mais alto da quadra. Quando o desnível se apresentasse muito grande em uma mesma quadra, as linhas horizontais deveriam ser mantidas em grupos de edificações contíguas, sendo que a ruptura das linhas deveria ser disfarçada. Esta regulamentação aplicou-se às ruas Líbero Badaró, São João, Conceição, Marechal Deodoro, Capitão Salomão, Quintino Bocaiúva e Benjamim Constant. O mapeamento destas leis, que atribuíram características específicas a determinadas vias da cidade, pode ser verificado no capítulo seguinte.

Neste mesmo ano, com a Lei no 1.596, foi alargada a Avenida São João, cujas construções deveriam ter no mínimo 3 andares e suas fachadas aprovadas pela Prefeitura. Foram também revisadas as dimensões das ruas Conselheiro Nébias, Barão de Limeira e Barão de Campinas, que após terem sido prolongadas formaram três praças com a Avenida São João. No ano seguinte, foram exigidas linhas arquitetônicas horizontais nas fachadas das edificações das ruas Doutor Falcão e Dom José de Barros até o Largo Santa Efigênia, com a Lei ํำ1.680.

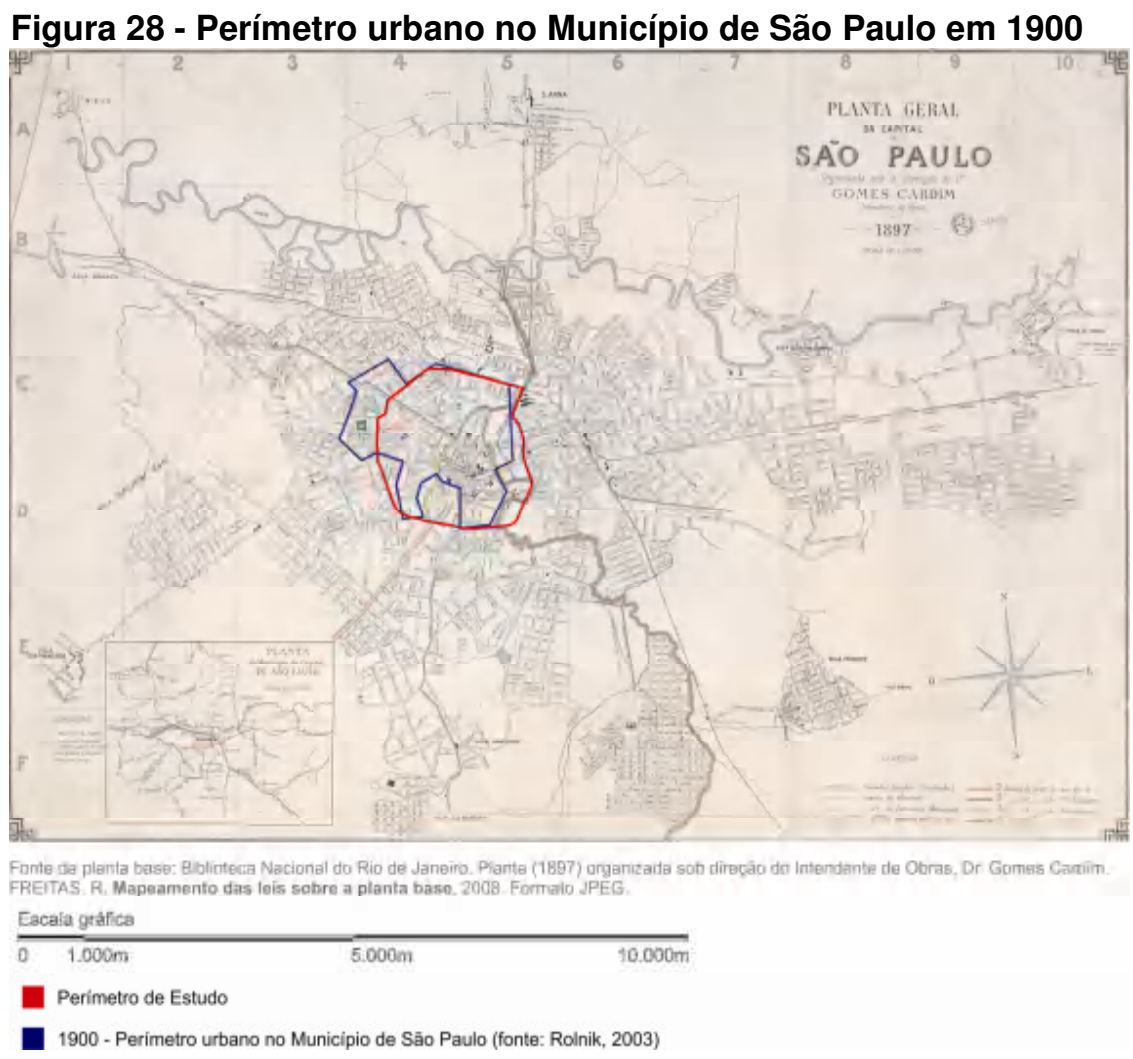


As leis urbanas paulistanas criadas no início do século XX aplicavam-se ao perímetro urbano, de acordo com ilustração acima.

Em contraposição aos planejamentos parcelados que caracterizavam o urbanismo em fins do século XIX e início do século passado, surgiu o movimento de planejamento de cidades. Iniciado com ímpeto em 1893 - após a Exposição de Chicago - produziu seus primeiros frutos nos EUA a partir de 1909, quando da inauguração do plano daquela cidade (por Daniel H. Burnham). Seus objetivos centrais eram: fazer uma cidade prática e bonita, estabelecendo um plano de realizações como a base em melhoramentos cuja perspectiva de realização seria de 50 anos. Enquanto isso, em São Paulo, a partir de 1914 continuaram a ser aplicadas ao perímetro central leis que regulamentavam, de modo tímido, os demais perímetros urbanos criados a partir desta data. Havia nas regras estabelecidas para esta cidade, um descompasso em relação ao pensamento corrente em outros países, caracterizado pela atividade de urbanistas que desenvolviam planos para cidades como um todo, vislumbrando horizontes com longos períodos de transformação urbana.

Por outro lado, apesar de São Paulo acompanhar de longe as discussões sobre urbanismo do mundo, havia naquele momento uma movimentação da administração pública em busca de sua própria estruturação, do ponto de vista técnico, a fim de se preparar para lidar com as questões urbanas que passavam a se apresentar. De acordo com FISCHER (2005), a Superintendência de Obras Públicas criada pelo Decreto no 6 de 1889, foi denominada Diretoria de Obras e Viação em 1913, pelos Atos no 573 e 574 daquele ano, passando a ser composta por três seções técnicas. A 1a seção era encarregada de projetos, especificações e contratos de obras de arte e arquitetura, da planta da cidade e de alinhamentos e licenças para edificações particulares; a $2^{\underline{a}}$ seção, da execução de estradas, ruas e calçamento; e a $3^{\text {a }}$ seção, da conservação do calçamento. Ainda em 1913 foi criada uma 4⿳亠丷a . seção, responsável exclusivamente pelos alinhamentos e licenças para edificações particulares, pela Lei no 1.756 de 1913, regulamentada pelos Atos no 815 e 816 de 1915. Tendo-se passados vinte e dois anos, a 4⿳亠丷a seção da Diretoria de Obras e Viação iria responder pelo cumprimento da Lei n 38 de 1893, que estabelecia a obrigatoriedade de aprovação de plantas para novas edificações. Portanto, entende- 
se que houve um período de acomodação entre 1893 e 1915, até que se tomassem medidas mais objetivas visando à efetivação da obrigatoriedade de aprovação de plantas na cidade.

Figura 29 - Lei no 1.585 de 1912

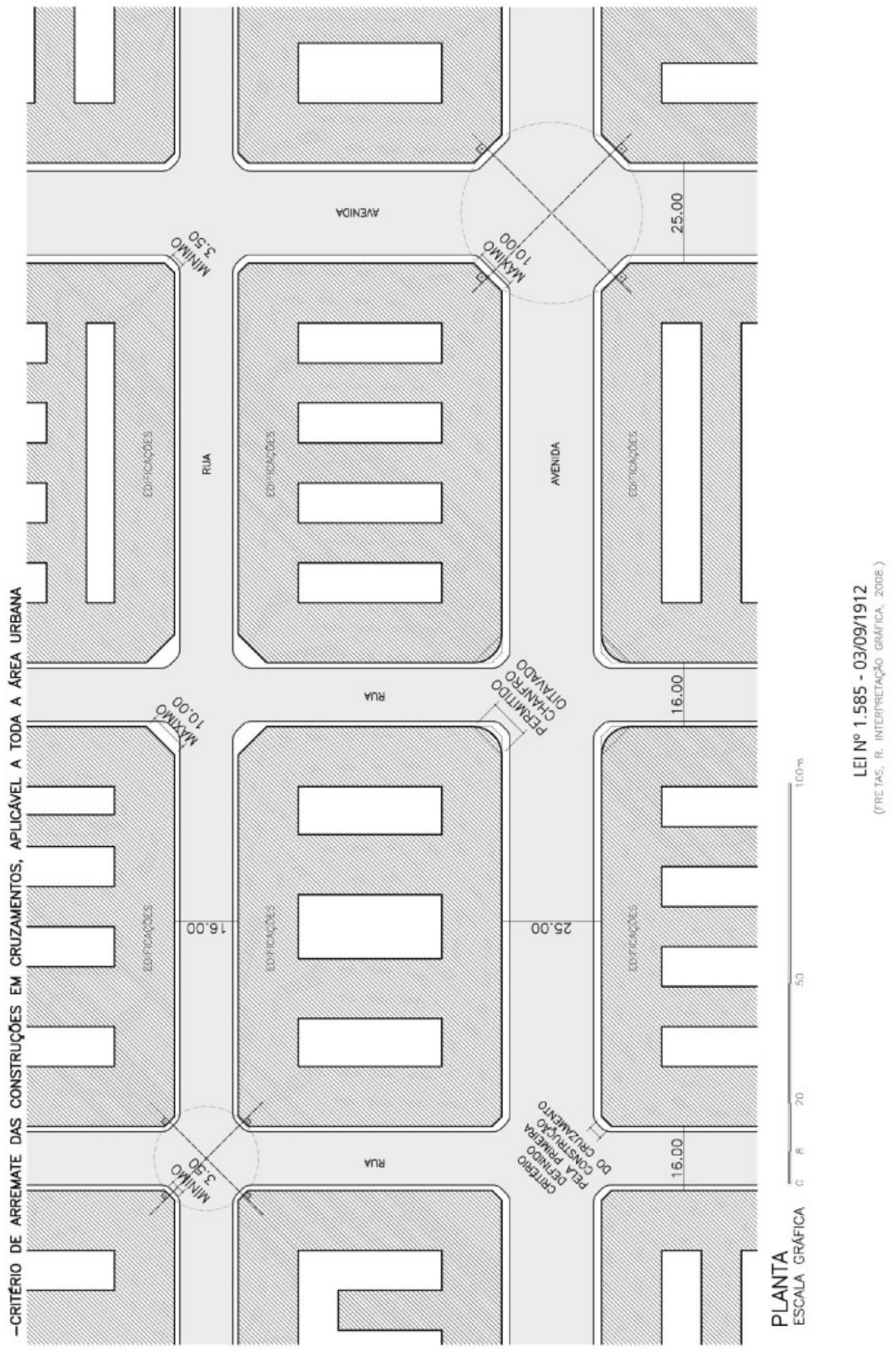


O Código de Posturas de 1886 vigiu até o início do século XX como regulamentação das edificações, em conjunto com o Código Sanitário Estadual de 1894. Em 1914, a Lei no 1.788 dividiu o município em três perímetros: urbano, suburbano e rural. Ao estudar as trajetórias profissionais dos engenheiros que atuaram em São Paulo neste período, LEME (2000) observou que estes técnicos responsabilizaram-se por funções advindas do investimento de receitas acumuladas com a agro-exportação. A balança comercial favorável, fruto da exportação do café, viabilizou a construção de ferrovias, a formação de companhias de abastecimento de água, transporte público, e iluminação. Esta autora ressalta ainda a indissociabilidade da estruturação do ensino do urbanismo na Escola Politécnica com formação dos quadros técnicos da Prefeitura Municipal e do Governo do Estado, nos setores ligados às obras públicas. Os engenheiros politécnicos ocuparam cargos de chefia no serviço público e foram os responsáveis pelas cátedras nesta escola. Verificou-se esta dupla inserção em cargos diretamente subordinados, que de maneira recorrente substituíam seus titulares quando das aposentadorias ou de afastamentos. Assim foi caracterizada a transmissão do conhecimento técnico e da forma de administrar São Paulo, sendo possível relacionar o conhecimento técnico que detinham às mudanças nas propostas da legislação urbana e tributação municipal.

O Ato oㅡ 849, de 1916, regulamentou a Lei oㅜ 1.874, de 1915, dividindo o município em quatro perímetros - central, urbano, suburbano e rural. Como observação, vale ressaltar que, apesar de a aprovação de plantas das construções no perímetro central ser indispensável, não era exigida no perímetro rural. Este ato, em seu artigo $10^{\circ}$, estabeleceu critérios e padrões técnicos para a apresentação de plantas, cortes e elevações de projetos a serem aprovados. Em seu artigo 19, definiu partes essenciais de uma construção, que deveriam seguir conforme projeto aprovado: 1. altura dos edifícios; 2. altura do pé direito; 3. espessuras das paredes; 4 . superfície dos compartimentos; 5 . alicerces e coberturas; 6 . altura e largura das aberturas; 7. acréscimos ou supressões de abertura; 8. tamanho das saliências. Manteve os critérios de áreas mínimas internas ao lote, para ventilação e iluminação, de acordo com a Lei o 498, de 1900. Manteve os critérios de fachadas conforme o Padrão Municipal de 1886. O artigo 29 previa recuo frontal de 10 metros e lateral de 2 metros para edificações à avenida marginal ao canal do Tamanduateí. Em seus artigos 44 a 97 definiu as construções, em geral, quanto a: $1^{\underline{a}}$. seção - fundações; $2^{2}$. 
seção - porões; 3a․ seção - paredes (altura, espessura, aberturas, saliências); 4 ${ }^{a}$. seção - estilo, compartimentos e coberturas; $5^{\text {a }}$. seção - canalização de água pluvial e potável, de esgotos, elétrica e de gás.

Fora do Brasil, a esse tempo, segundo LEFEVRE (1951), os planejadores de Chicago já teriam vislumbrado as tendências que assumiria a seguir a campanha de melhoramento da vida humana. O movimento que inicialmente fora caracterizado por planos de city beautiful, como em Washington, Filadelfia, St. Louis e New York planos de embelezamento por parkways e centros cívicos - foi revisado de 1915 a 1932. As novas correntes de pensamento assumiram caráter diferenciado, em busca de justificar os benefícios decorrentes do alargamento de ruas, do desenvolvimento dos sistemas de transportes, da abertura de autovias urbanas, do estabelecimento de regras de zoneamento, de parques e outros espaços livres para recreação, mesmo que quase desprezando o problema da habitação. Entretanto, foi neste período que planejadores de cidades conscientizaram-se sobre a importância econômica e social das aglomerações humanas.

Figura 30 - Perímetros do Município de São Paulo em 1914, Lei no 1.788/1914

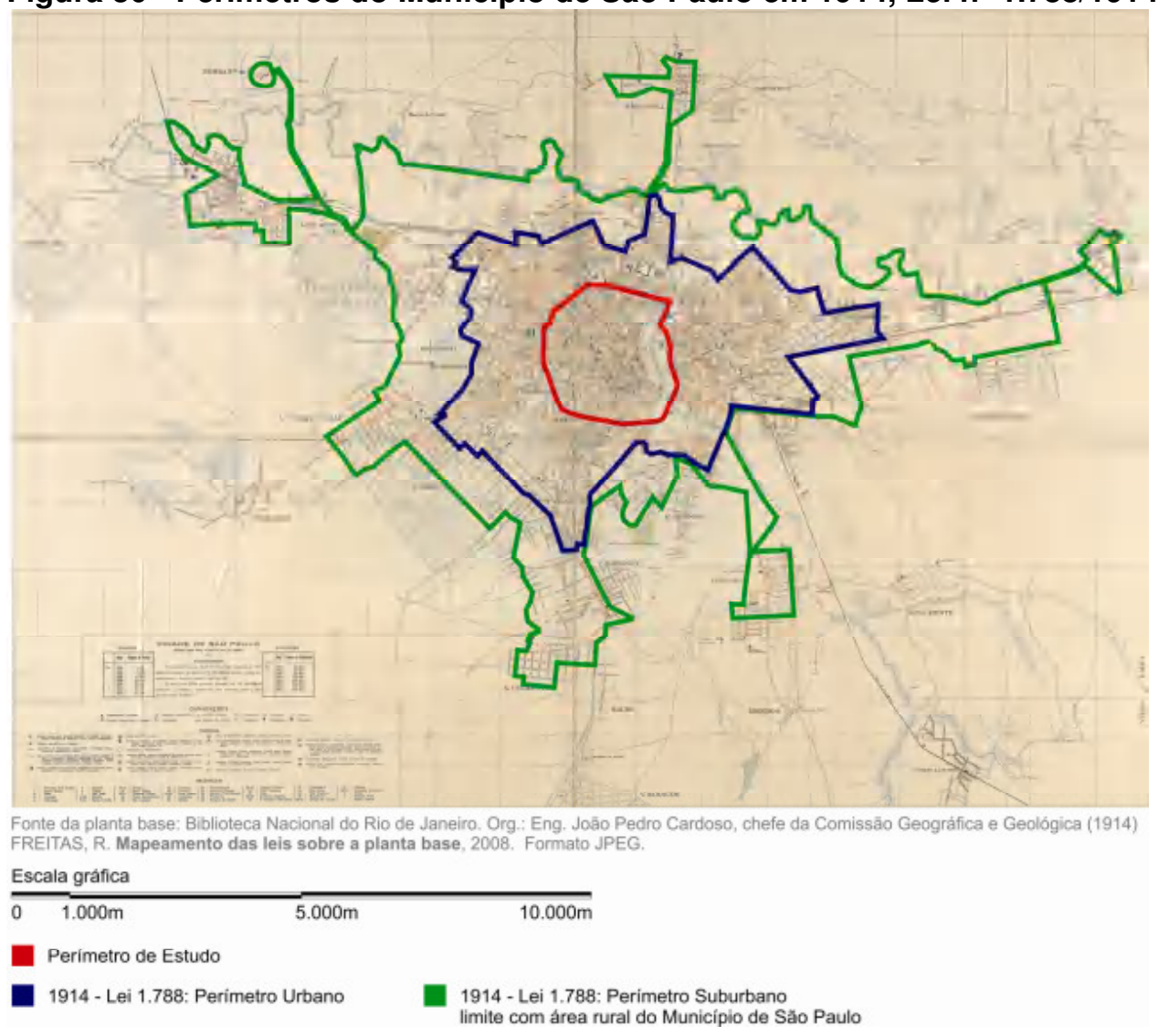


Em 1915, a Lei no 1901 estabeleceu critérios para redução de pé direito em edificações à Avenida São João, entre a Praça Antonio Prado e a Rua dos Timbiras (vide mapeamento no próximo capítulo).

Figura 31 - Lei no 1.901 de 1915

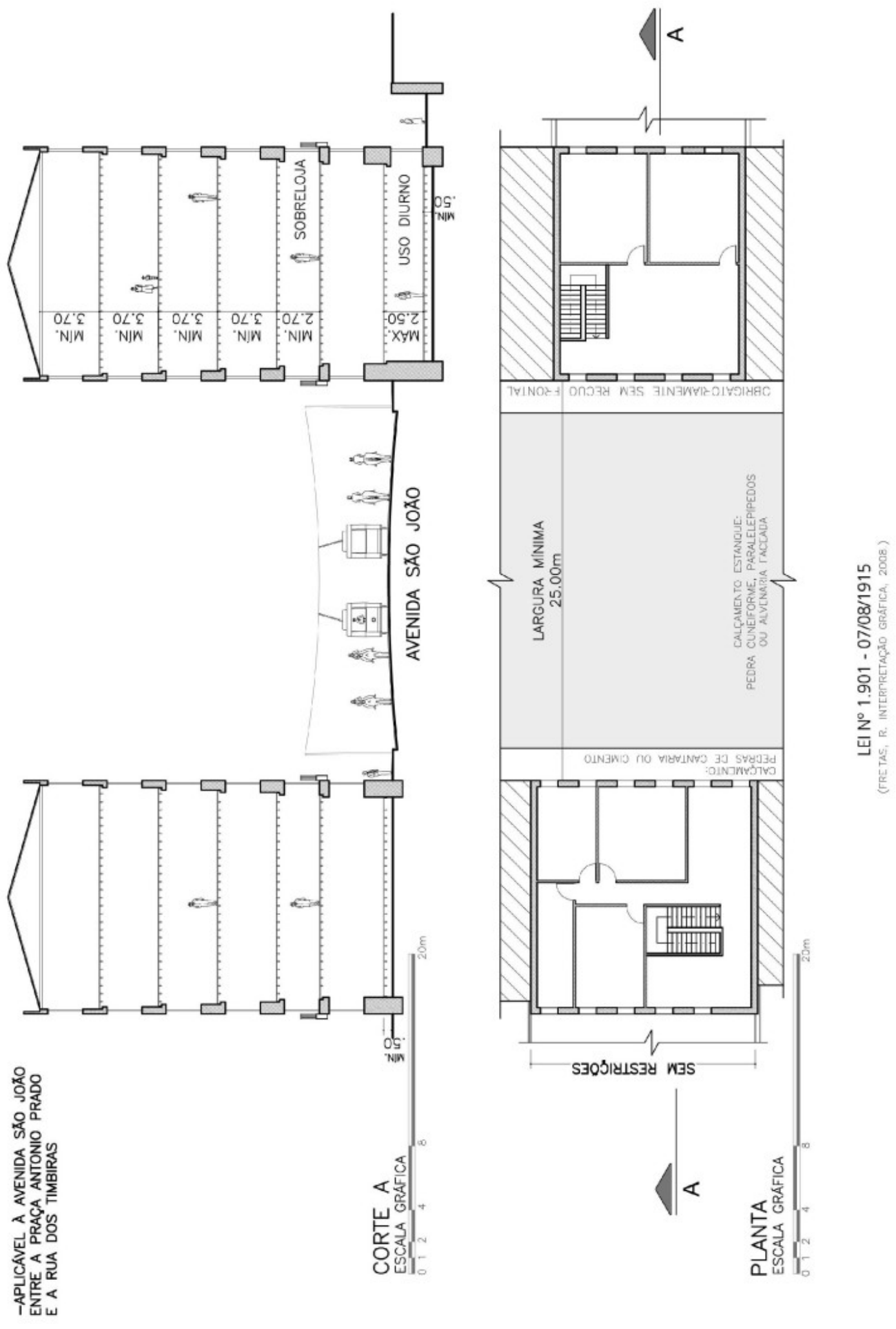


O Ato $\mathrm{n}^{\circ} 900$ de 1916, definiu critérios para insolação dos ambientes, seguindo estudos do arquiteto Alexandre Albuquerque ${ }^{5}$, no artigo 1을

A. No perímetro central: nas áreas internas o plano horizontal de referência será ao nível do soalho do pavimento imediatamente superior ao embasamento;

B. Dividir-se-á a superfície total das paredes da área acima do plano de referência, pela extensão total dessas paredes, segundo o mesmo plano;

C. Dividir-se-á a superfície total das paredes da área acima do plano de referência, da metade do perímetro, completo da área cuja concavidade olha para sul, na extensão correspondente dessas paredes, no mesmo plano.

Artigos $2^{\circ}$ e $3^{\circ}$ :

Sendo $10 \mathrm{~m}^{2}$ a superfície mínima da área, com lado menor mínimo de $2.00 \mathrm{~m}$, a fim de encontrar tal área, multiplica-se o maior dos quocientes (B ou $\mathrm{C}$ ) de acordo com croqui:

Figura 32 - Ato no 900 de 1916

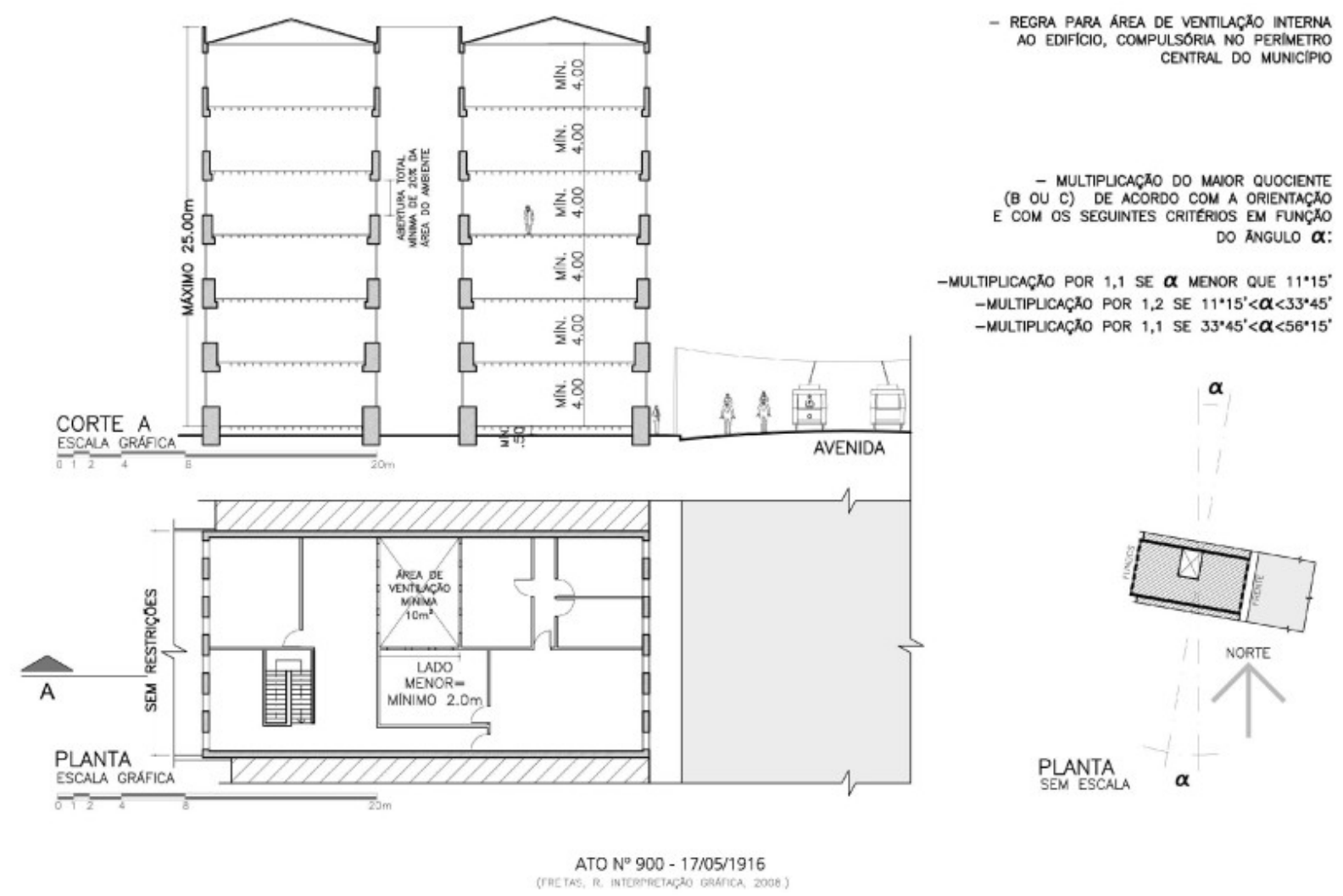

\footnotetext{
${ }^{5}$ Alexandre Albuquerque estudou no Colégio Militar e cursou a Escola de Engenharia do Rio de Janeiro até 1899, quando transferiu-se para a Escola Politécnica de São Paulo. Já em 1903, participou da fundação do Grêmio Politécnico, sendo seu primeiro presidente.(Disponível em:<http://www.poli.usp.br/Organizacao/Historia/Diretores>. Acesso em: 10 jul 2007)
} 
Figura 33 - Ato no 900 de 1916
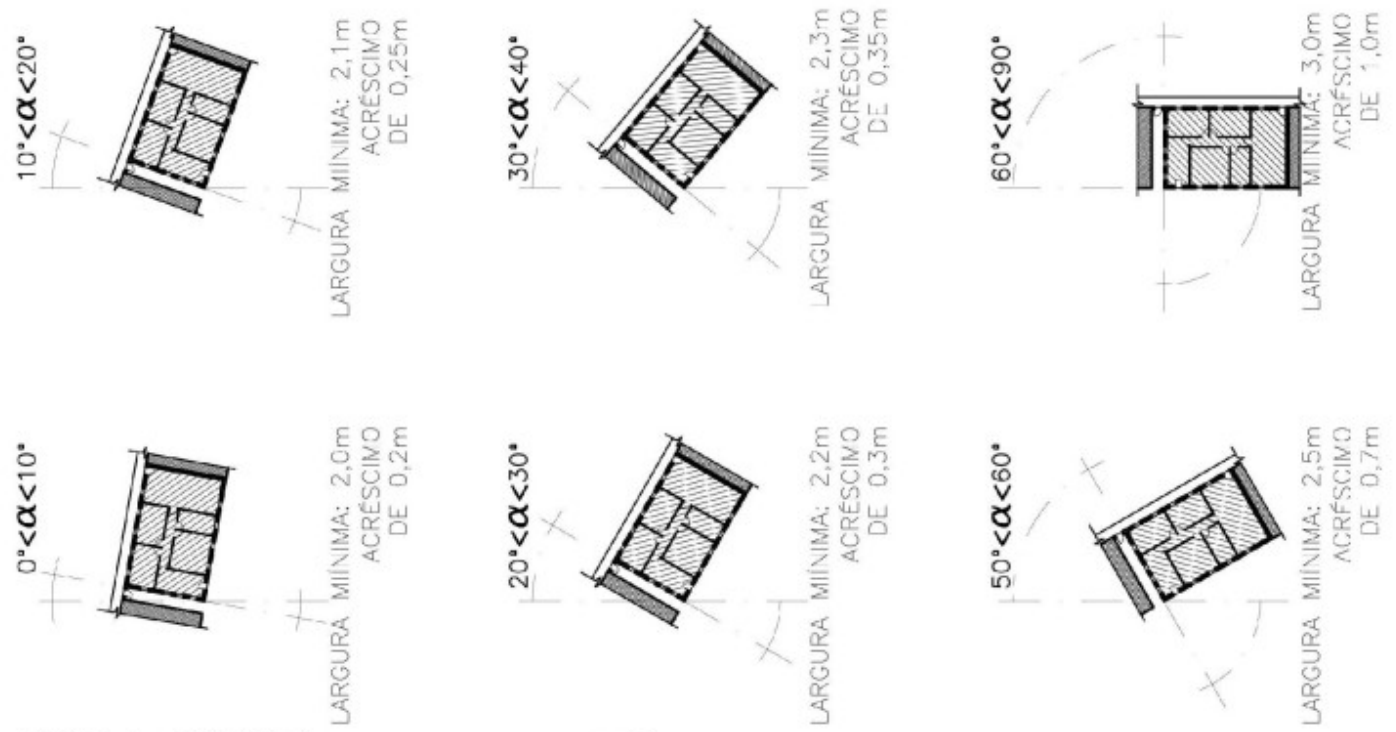

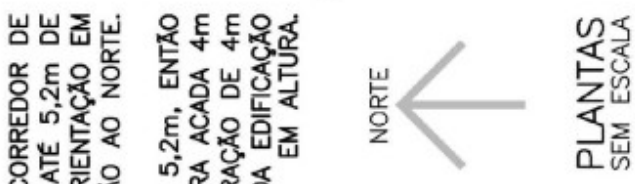

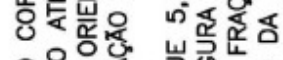

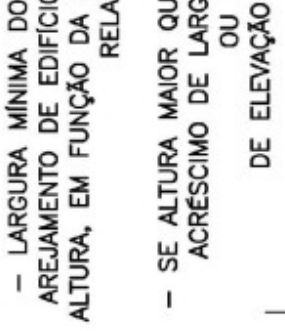

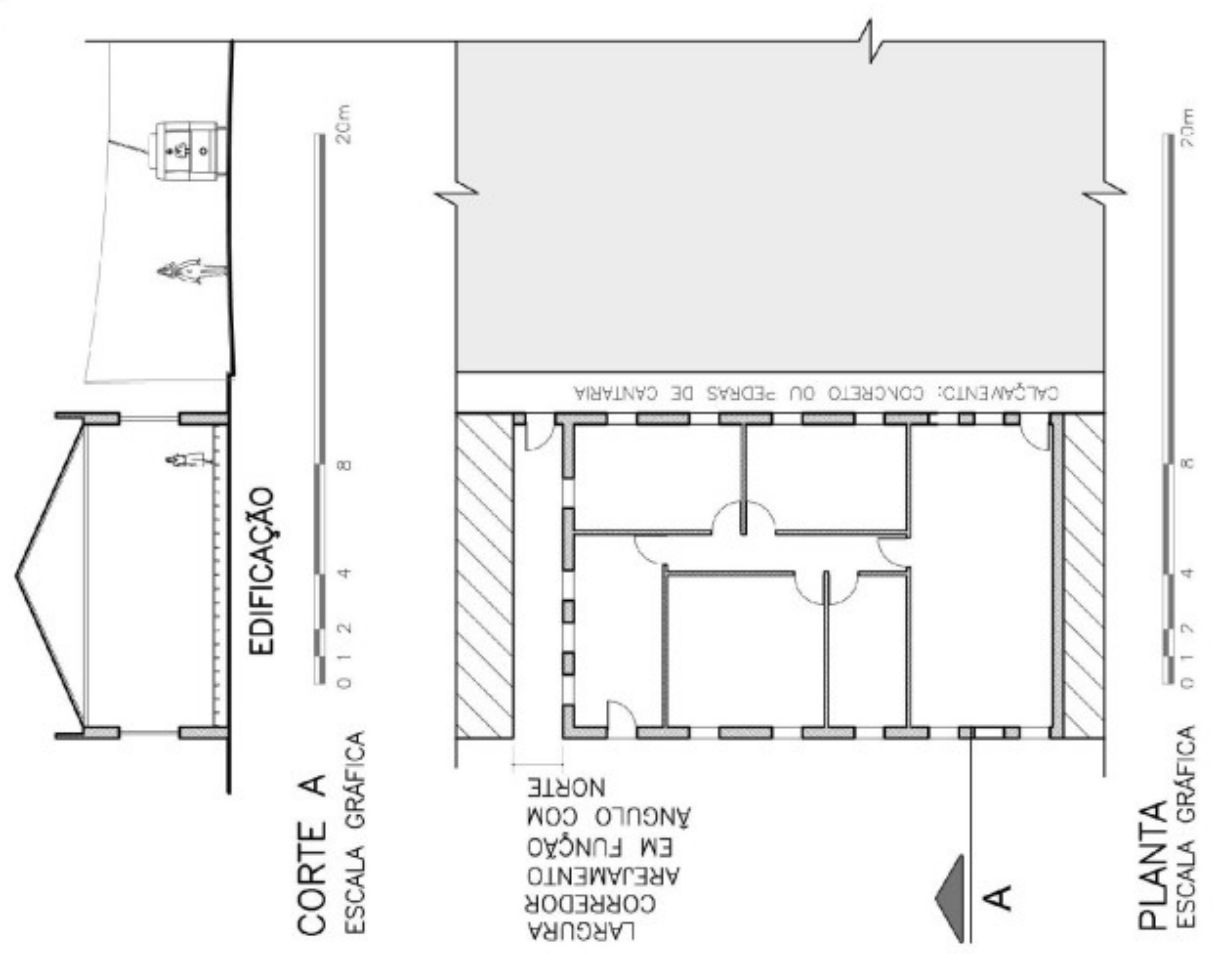


Pode-se dizer que os Atos n 849 e no 900 constituíram-se como o primeiro Código de Obras de São Paulo em 1916, estabelecendo rigorosas especificações técnicas construtivas que deveriam ser seguidas nas novas obras particulares. Segundo Victor da Silva Freire, diretor do Setor Municipal de Obras entre 1899 e 1925:

'Agrupam-se os homens em aglomerações para colherem as vantagens da cooperação, da divisão do trabalho, para produzirem, n'uma palavra, mais econômicamente. (...) Essa vida em communidade acarreta, por seu lado, inconvenientes desconhecidos ao estado de disseminação. Inconvenientes que apresentam uma gama variadíssima e que se estendem desde o enfraquecimento directo das condições de resistência do organismo individual até a ameaça na ordem moral, de dissolução da própria família. Vão repercutir taes inconvenientes na capacidade de produção da sociedade, essa mesma capacidade que ela busca justamente avollumar pela agglomeração. Tendem a diminui-la. Pela morte: attribue-se dez a vinte contos ao equivalente de um Brasileiro, valido e trabalhador. Pela enfermindade, pela degennerescência, pela prostituição, pela embriaguez, pela vagabundagem, pelo crime, obrigando o Estado a multiplicar os hospitaes, asilos, prisões e o policiamento.

Parte, e não pequena, de semelhantes incovenientes vae encontrar a sua origem nas condições de alojamento, as quaes dependem immediatamente da respectiva distribuição, fabricação e acesso. (...)

O que elles devem ter em vista pois, esses códigos sanitários e municipaes é um duplo objetivo:

Primeiro - positivo, de protecção e amparo - proporcionar à parte da população que aspira viver n'um ambiente sadio e decente, e educar a sua prole em condições de dignidade, disposições que facilitem realisar essa tão legitima ambição;

Segundo - negativo, de repressão e policia - impedir que a parte restante, a qual pouco se importa com tudo isso, ou é incapaz de tentar o esforço necessário para o alcançar, possa crear situações que venham a constituir ameaça para os visinhos, para a communidade e para a civilização' (FREIRE, 1918, apud ROLNIK, 2003, p.43).

Segundo ROLNIK (2003), a tese básica de Victor da Silva Freire consistia na necessidade de pensar a higiene e o rendimento da cidade simultaneamente, induzindo uma política de adensamento sem congestionamento, propondo:

1. A utilização de porões para habitação, diferenciando embasamentos (cômodos parcialmente enterrados) de porões e sugerindo técnicas de aeração e iluminação desses porões;

2. A diminuição radical de pés-direitos e o aumento do número de andares das construções. 'Baixados os pés-direitos, utilisados os subsolos em condições aceitáveis, não seria a população que se revoltaria contra uma transformação que desde logo Ihe assegurava allivio imediato no bolso.' 
A justificativa técnica apresentada desmontou a doutrina química da ventilação, ou seja, a idéia de que se deve exigir uma cubagem mínima de ar por habitante. Defendia a necessidade de evitar a superlotação, mas considerava que o controle do número de pessoas morando juntas deveria ser assunto da autoridade sanitária, que não poderia ser definido por normas de construção.

Em relação à altura das edificações e à largura das ruas, Victor da Silva Freire criticava a uniformidade de largura das vias e o tamanho das quadras propostos pelo Código, provando que diferentes usos e diferentes densidades geram larguras de vias e dimensões de quadras diversas, fruto de estratégias distintas de utilização dos lotes.

Porém, 'quando não existe em uma cidade a divisão em bairros com destino certo e imutável, como se pratica na Allemanha e começa agora a realisar-se na América do Norte, é necessário constituir o lote para o que der e vier.'

Assim, com base nos estudos de Alexandre de Albuquerque sobre ventilação, propõe Victor Freire um lote padrão com profundidade variando entre 9 e 16 metros, o que, entre outras vantagens, diminuiria o risco de o proprietário construir casas de fundo para alugar.

Embora absolutamente inteirado do zoning que ocorria naquele momento na Europa e Estados Unidos, Victor da Silva Freire não defendia sua adoção imediata na cidade de São Paulo:

'O Congresso Internacional de Urbanismo (Art de Construire les Villes) reunido em Gand, 1913, aprova a resolução convidando os Governos e as Administrações Municipais a tomar as medidas necessárias para o estabelecimento de posturas de construcção distintas, no momento de serem adotados os planos de extensão das cidades, obedecendo aos differentes bairros e ruas projectados e de accordo com a natureza dos edifícios a serem erigidos. Estamos entre as cidades que ainda não conceberam o seu plano de expansão - a solução virá aqui a seu tempo; o nosso meio parece-me cru ainda para este progresso, que constitue a verdadeira orientação da legislação sanitária.'

Considerado um avanço impossível para o "meio" paulista, a lógica do zoneamento, que só se estabeleceu em 1972, foi, no entanto, incorporada conceitualmente e introduzida aos pedaços.(ROLNIK, 2003, p.43).

A necessidade de zoneamento só se torna premente a partir de determinadas transformações das funções urbano-rurais, em que a não-segregação de certos usos ou a não-limitação das suas intensidades podem criar problemas à sobrevivência de todo o sistema (ZMITROWICZ, 1979, p.60).

A Lei no 2.119 de 1918, regulamentada no mesmo ano pelo Ato nำ1.235, incorporou às posturas municipais as exigências higiênicas feitas pelo Serviço Sanitário do Estado na parte referente às construções e reconstruções de prédios urbanos conforme Lei Estadual nº 1.596 de 1917. Na cidade de São Paulo, assim como em 
Nova lorque, o primeiro período de criação de leis urbanas segue os progressos da medicina preventiva, provenientes das conquistas da profilaxia de moléstias contagiosas, verificadas no período chamado por alguns autores de era Pasteur.

Constituído sob o comando de Victor da Silva Freire, o código de obras de 1916 (Atos n 849 e nำ 900) seria alterado sob sua orientação pela Lei n. 2.332 de 1920, para edifícios construídos no alinhamento das vias públicas - altura: mínima 5,00 metros, máxima 2,0 vezes a largura da via, no caso de sua largura ser menor que 9 metros; máxima 2,5 vezes a largura da via, se sua largura estivesse entre 9 e 12 metros; e 3,0 vezes a largura da via, quando sua largura fosse maior que 12 metros.

A Lei 2.332/20 definiu também os procedimentos para a obtenção do alvará de construção e da determinação das peças que deveriam constar do projeto da obra a ser aprovada, vinte e cinco anos depois de estabelecida a obrigatoriedade de aprovação dos projetos. Ou seja, plantas, elevação da fachada, planta de localização, cortes transversal e longitudinal, a exigência da participação de um profissional projetista e sua qualificação, sendo compulsória em todas as peças do projeto a assinatura do proprietário da edificação, ou seu representante legal; do engenheiro, ou arquiteto, autor do projeto, vinte e sete anos após a regulamentação da Escola Politécnica em São Paulo. Esta lei estabelecia também que, para dirigir as obras de qualquer edificação, seria necessário que o construtor tivesse diploma ou título registrado na prefeitura e quitado previamente os impostos e emolumentos pertinentes. Em seu artigo 100, esta lei exigia construções com no mínimo 4 pavimentos além do embasamento, continuidade das linhas mestras arquitetônicas (cornijas, molduras, etc.) em edificações contíguas, bem como mesmo "motivo arquitetônico" e quando impossível de se seguir tal critério, no remate dos prédios, evitar diferenças bruscas de nível ou terminação em plano vertical normal à fachada. O artigo 100 era exigido para as construções no Triângulo Comercial e ruas Marechal Deodoro, Capitão Salomão, Quintino Bocaiúva, Boa Vista, São Bento, São João, Líbero Badaró, Dr. Falcão, Dom José de Barros, Antonio de Godói, Xavier de Toledo, Barão de Itapetininga, Conceição, largos da Sé e São Bento. O mapeamento dos perímetros de abrangência destas regulamentações pode ser verificado mais adiante, no capítulo 5. 
Figura 34 - Ato no 1.235 de 1918 incorporou Lei Estadual no 1.596/17

紫要

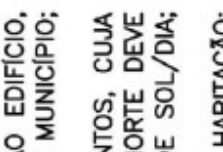

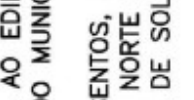

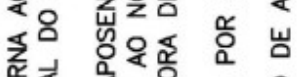

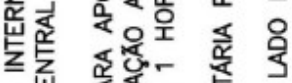

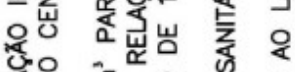

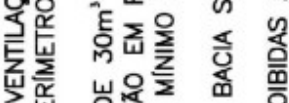

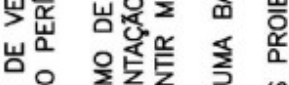

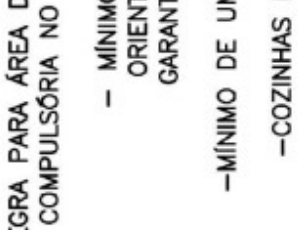
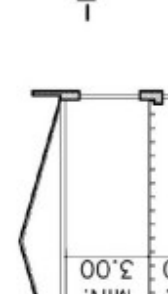

$00^{\circ} \varepsilon=00^{\circ} \varepsilon: 00^{\circ} \varepsilon: 00^{\circ} \varepsilon=0 c^{\prime} \tau$

NIN : NJW: : NIW : NIW $=$ "NJW

$\perp$
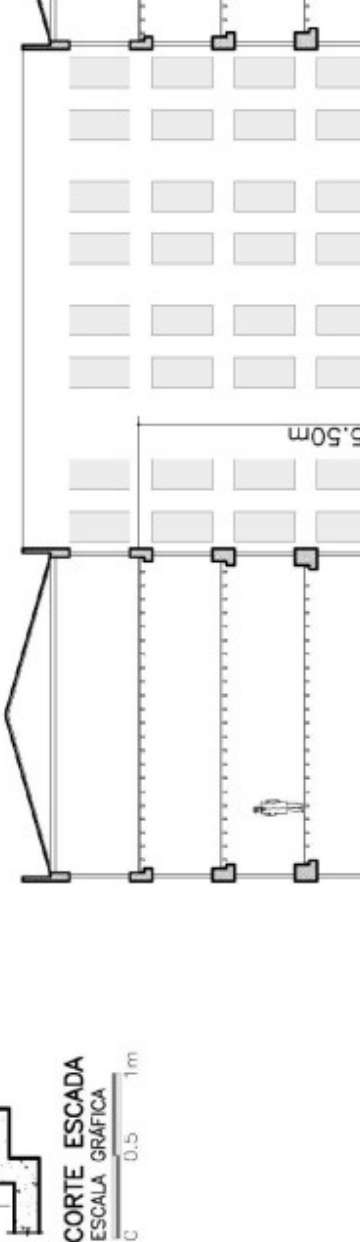

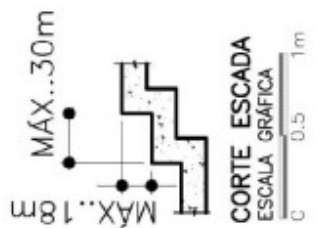

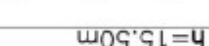

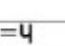

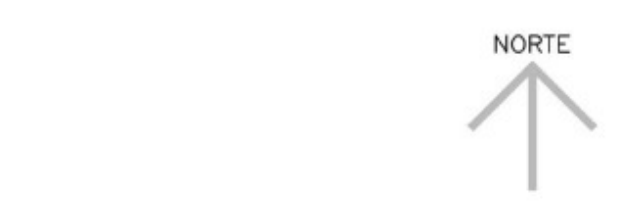

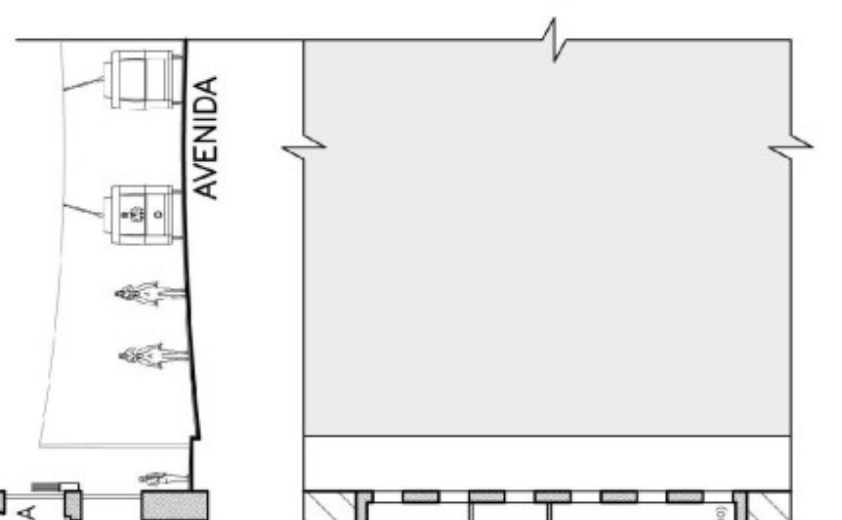

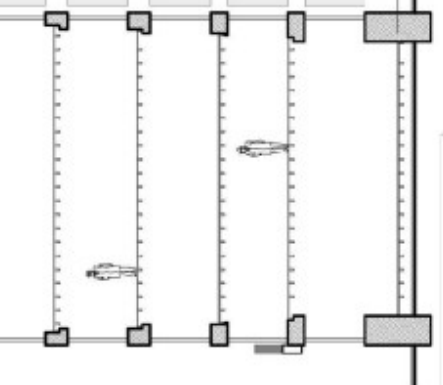
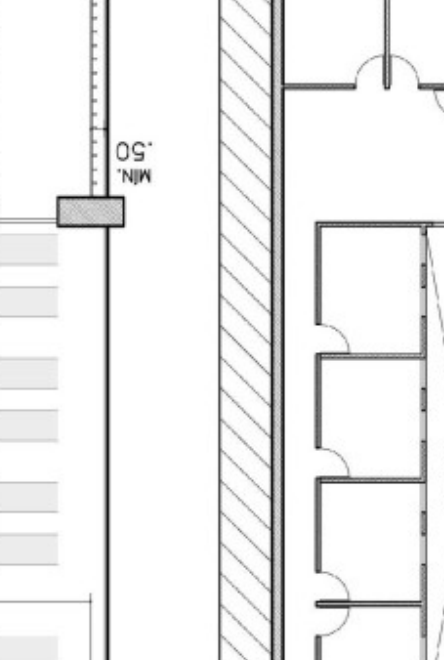
Figura 35 - Lei no 2.332 de 1920

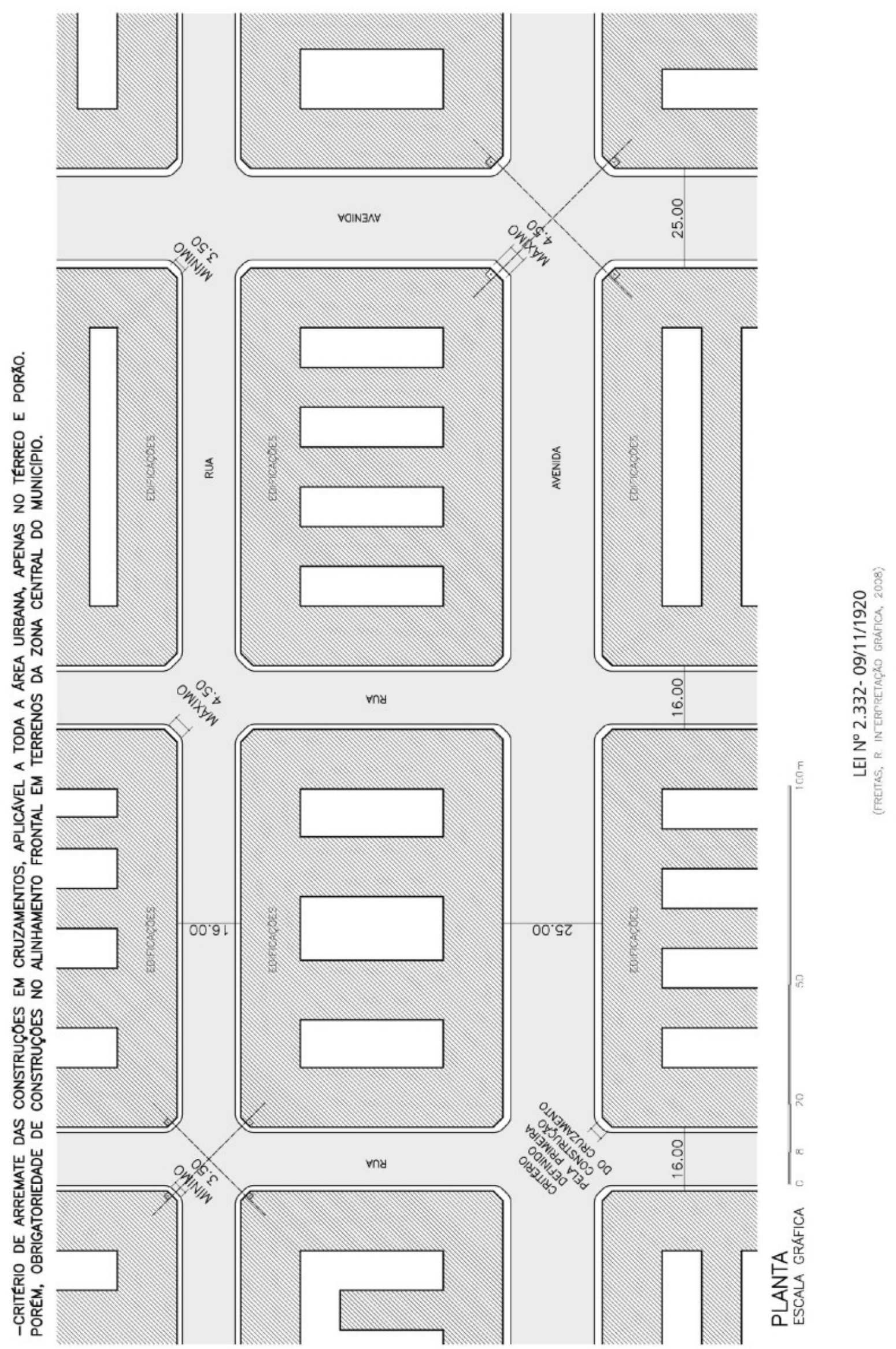


Figura 36 - Lei no 2.332 de 1920

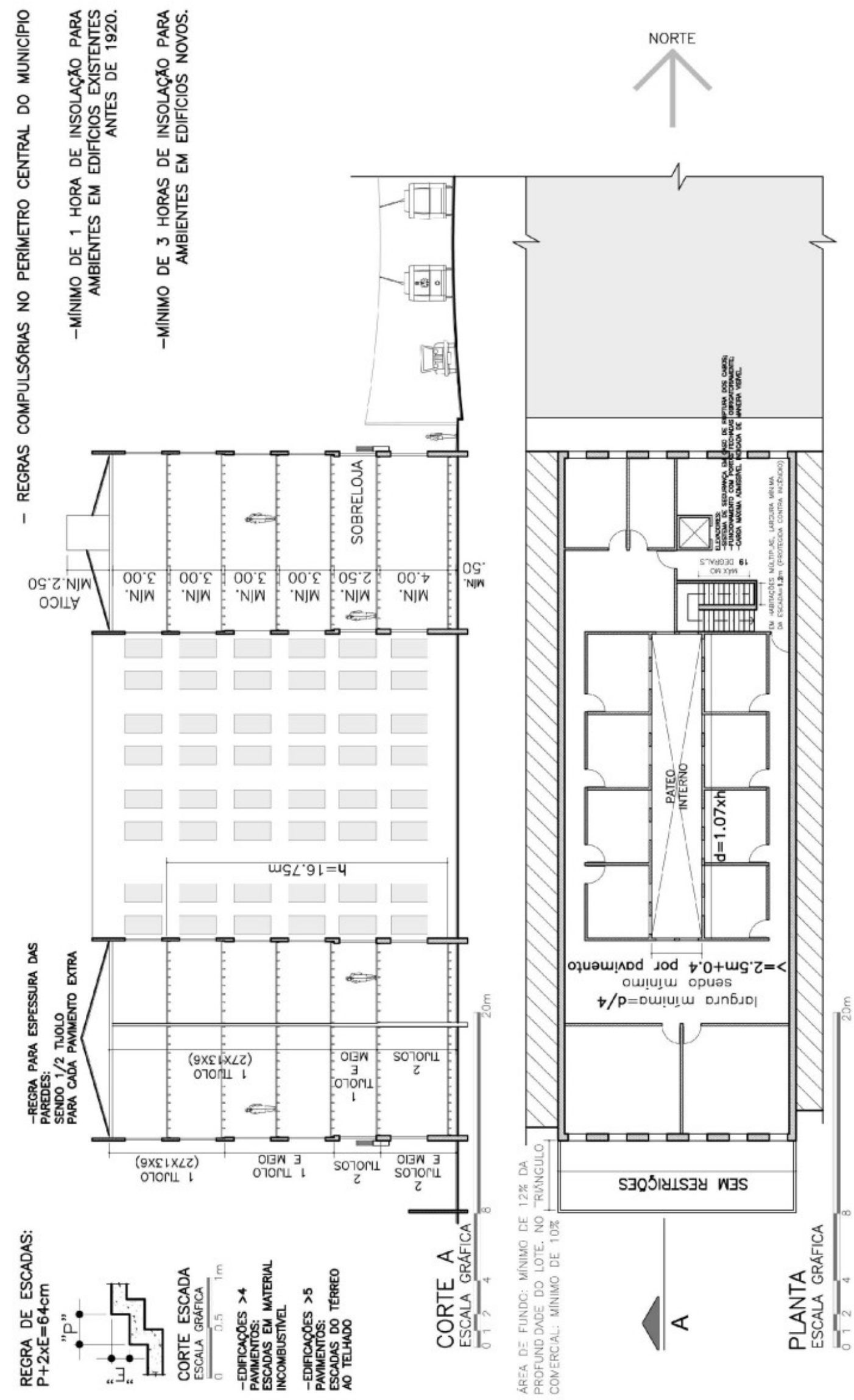


Figura 37 - Lei no 2.332 de 1920
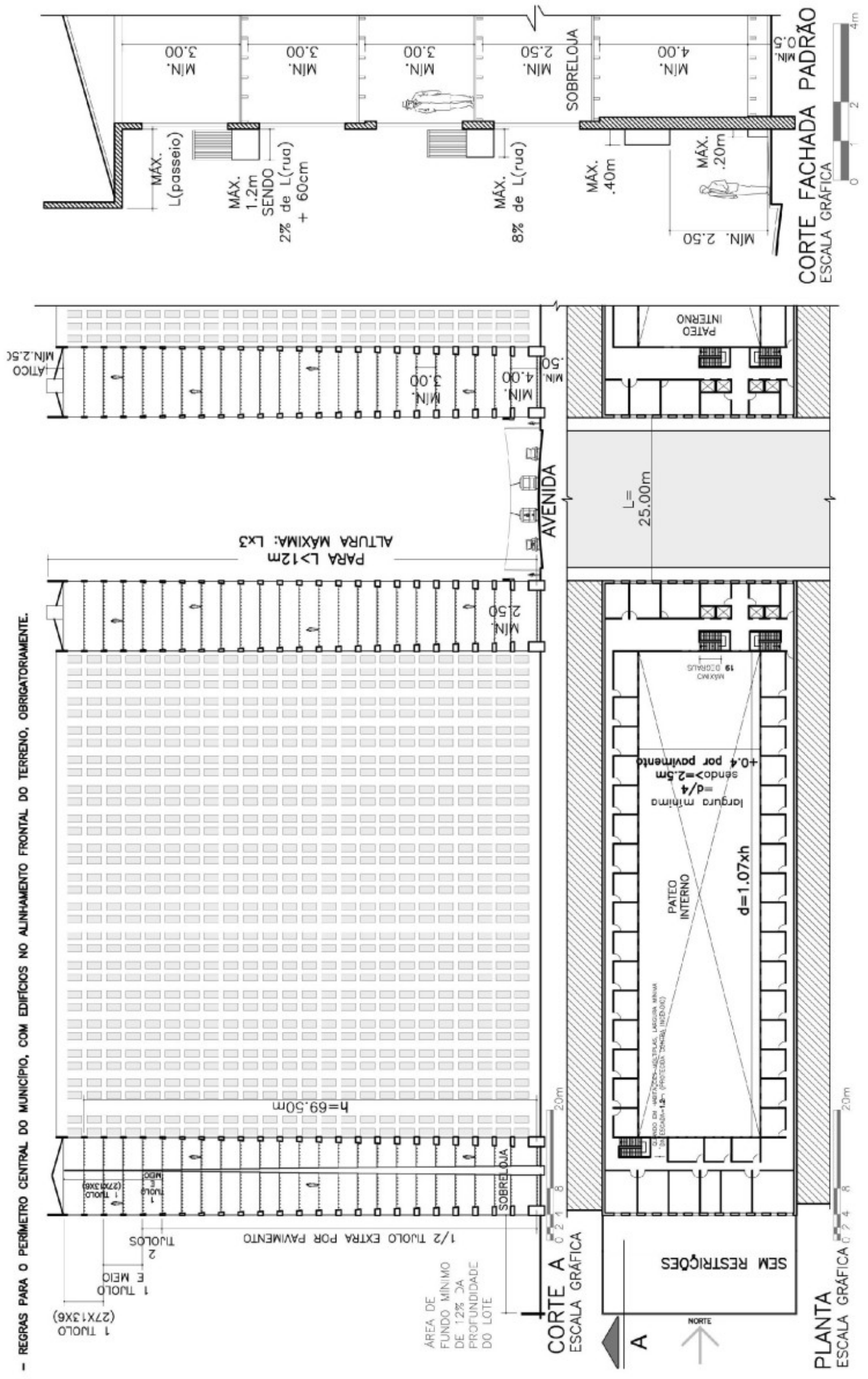
Figura 38 - Lei no 2.332 de 1920

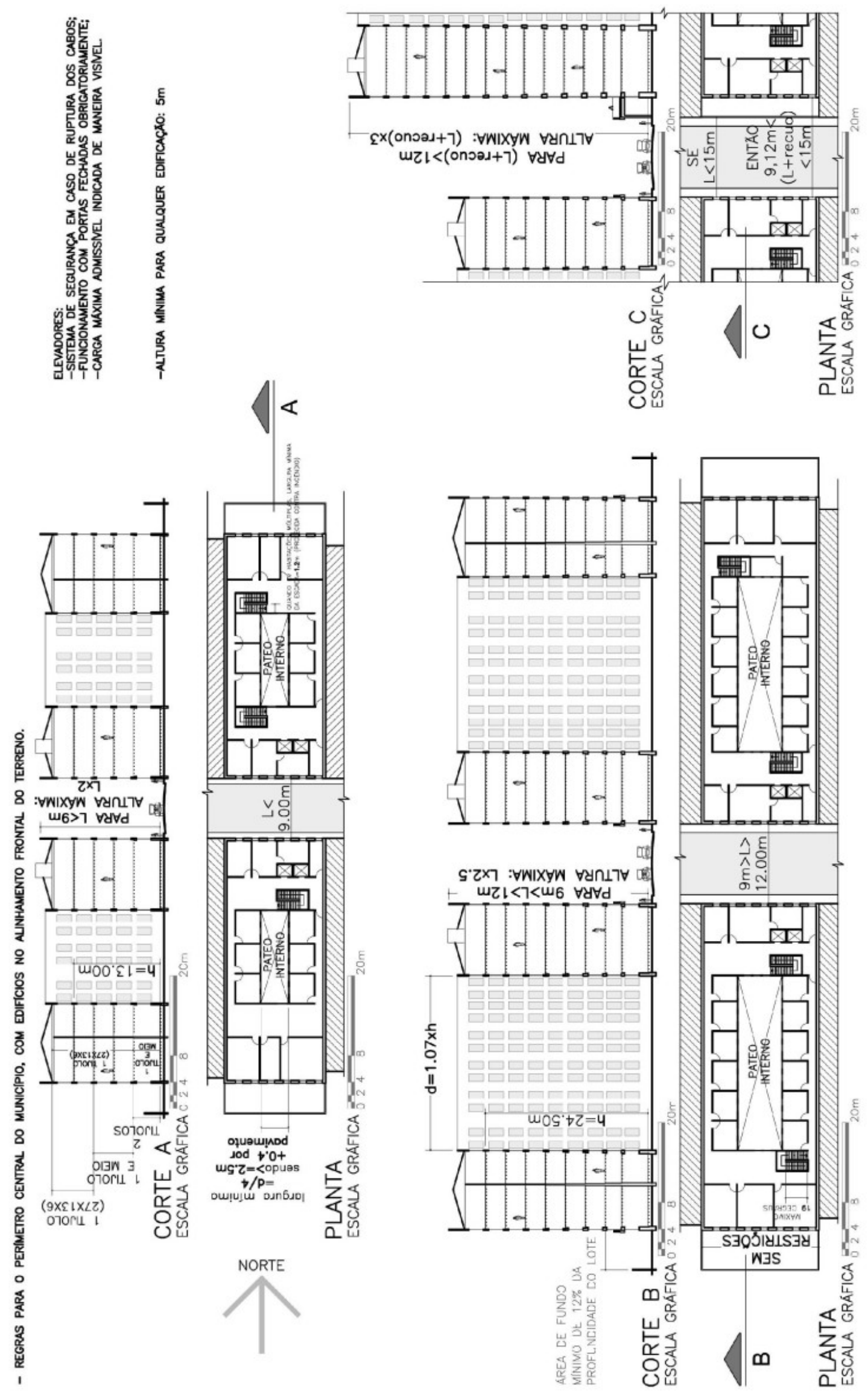


Figura 39 - Divisão do município de São Paulo: Lei no 1.874/15

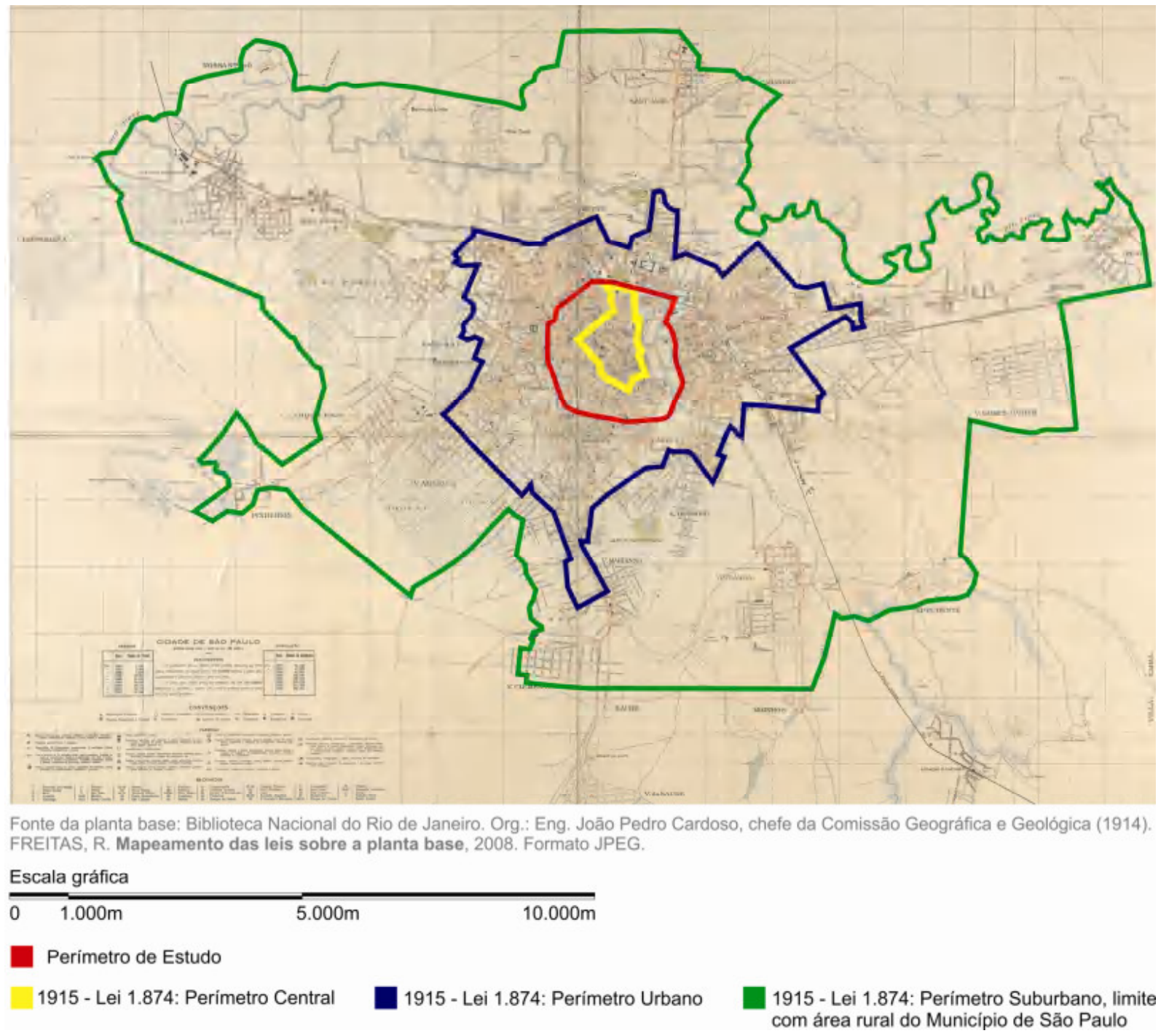

A Lei 2.332/20 estabeleceu critérios mais específicos para dimensionamento de corredores e escadas internas, no que diz respeito à iluminação e ventilação, citou critérios básicos para instalação de elevadores, especificações e exigências para cozinhas, copas/despensas, galinheiros, lavadouros, garagens, tapumes e andaimes de obras. Definiu critérios específicos para o uso de diversos materiais de construção e alvenarias: tijolos, areia e cal, cimento portland, argamassa, concreto e concreto armado, madeira, ferro e aço. Caracterizando-se, assim, como um manual de construção, do ponto de vista estrutural, incluindo proporções, sobrecargas a serem consideradas, coeficientes de segurança e fórmulas específicas para o uso de cada material, bem como especificações rigorosas para os alicerces. 
A lei $2.332 / 20$, inspirada no New York Building Code, abria possibilidade de aumentar a altura dos edifícios, desde que se recuasse da via pública o número de metros necessários para atingir as larguras de rua tratadas no artigo anterior.

Como, de acordo com a definição dada pela mesma lei, na zona central não eram permitidas edificações recuadas do alinhamento, sinalizava-se claramente para a verticalização do Centro, ao mesmo tempo em que se enunciavam seus limites e critérios. Não podemos nos esquecer de que, nesse período, uma parte das ruas da zona central já havia sofrido alargamentos e remodelações, abrindo maiores possibilidades de adensamento construtivo.

No entanto, até 1920 os prédios com mais de três ou quatro pavimentos eram exceções; essa proporção foi crescendo nos anos 20 e, em 1929, os prédios novos com mais de dois andares já constituíam $45 \%$ do total de prédios aprovados. Começaram, então, os conflitos em torno dos limites de altura dos edifícios. O edifício Sampaio Moreira, em 1924, foi o primeiro a contrariar as disposições da lei, com 14 pavimentos ou 50 metros de altura, na rua Líbero Badaró, de 15 metros de largura (ROLNIK, 2003, p.128).

Vê-se pela transcrição acima que o edifício Sampaio Moreira foi aprovado, apesar de estar em desacordo com a lei vigente no momento de sua construção. Pode-se entender que, a partir deste momento, o centro da cidade de São Paulo começou a refletir a insegurança das bases conceituais pelas quais foram criadas as leis até então. Vale ressaltar que este edifício tinha cinco metros além do que era permitido pela Lei no 2.332/20, que seria correspondente a três vezes a largura da Rua Líbero Badaró, com quinze metros de largura na época. Cinco anos após ter sido aberto este precedente, construiu-se o edifício Martinelli, também em desacordo com a legislação, quanto a sua altura.

Porém, se o critério de proporção entre largura de via e altura da edificação não foi respeitado em 1924 para o edifício Sampaio Moreira e tampouco para o Edifício Martinelli em 1929, pode-se dizer que os mesmos lotes do século XIX, no centro, já não tinham limites de altura e que os critérios de frente mínima de 10 metros para 0 dimensionamento de lotes - criados pelas leis da década de 1920 - não teriam efeito, uma vez que, desde fins do império, grande parcela desta região encontravase loteada, conforme verificado no levantamento de 1893, feito pelo engenheiro $\mathrm{V}$. Huet de Bacellar (exposto no capítulo 2).

Sabendo-se que a lei deveria regulamentar os lotes de maneira imparcial, com a aprovação ilegal destes dois edifícios pela Prefeitura do Município de São Paulo, 
outros proprietários de terrenos provavelmente exigiram aos seus representantes na Câmara de Vereadores, seus direitos de construir seguindo os mesmos critérios. Deste modo, em 1929 a legislação foi alterada, com a Lei № 3.427 - exposta com detalhes mais adiante e mapeada no próximo capítulo - que passou a permitir edifícios com até 80 metros de altura. Este é o exemplo mais relevante pelo qual se constatou um movimento inverso no processo de criação das leis em São Paulo, isto é, transformou-se a legislação urbana em função de obras edificadas ilegalmente. Entendendo-se a lei como estrutura organizacional (não-física) da paisagem urbana - que por sua vez, neste trabalho, é entendida como um fluxo - vêem-se os edifícios Sampaio Moreira e Martinelli como estruturas físicas transformadoras da lei, que neste momento específico, é entendida como estrutura que passou a ser fluxo. Entende-se desta maneira estes edifícios como a materialização de uma nova estrutura conceitual, não-física, que passava a predominar nas mentes dos técnicos ligados à criação e revisão das leis urbanas.

Figura 40 - Modelo idealizado de cidade, refletido nas leis paulistanas

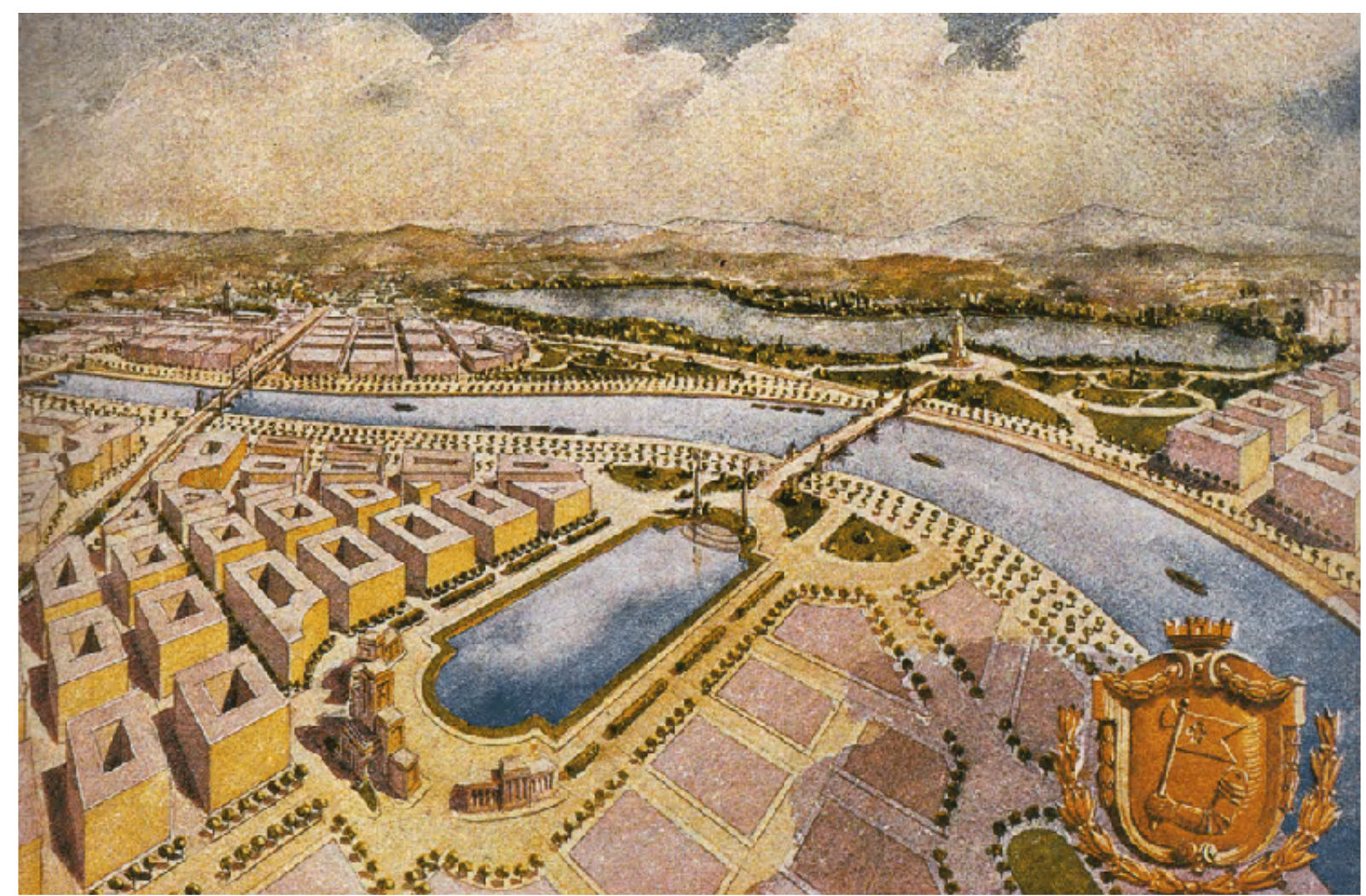

MAIA, F. P. Estudo de um Plano de Avenidas para cidade de São Paulo. São Paulo, Melhoramentos, 1930. in TOLEDO, 1996, p.270. - Proposta de Prestes Maia para as margens do Rio Tietê em São Paulo 
LEME (2000) diz que a qualidade dos projetos e planos urbanísticos do início do século evidencia como estavam atualizados os conhecimentos técnicos dos engenheiros brasileiros em obras de infra-estrutura e serviços urbanos, a exemplo dos projetos de canalização do rio Tietê. Estes profissionais detinham uma cultura urbanística onde estava presente a preocupação com o resultado estético, perceptível na ênfase legal dada às fachadas frontais dos edifícios e na manutenção de uma comissão de estética da prefeitura, responsável por definir se as edificações teriam ou não alvará de construção, por estarem ou não de acordo com os critérios estéticos predominantes àquele período.

Porém, se estivessem consolidados os conceitos urbanísticos que teriam fundamentado as leis edilícias até 1920, ilustrados na figura acima, não se teria aberto um precedente para o edifício Sampaio Moreira e cinco anos mais tarde para - edifício Martinelli, apesar da lei. Pode-se entender que havia incertezas conceituais quanto ao que se pretendia para o espaço urbano do centro paulistano, do ponto de vista dos técnicos, engenheiros e engenheiros-arquitetos responsáveis pelas propostas oficiais do município para a regulamentação e desenvolvimento do espaço edificado em lotes particulares. Talvez novas correntes ideológicas estivessem se sobrepondo aos ideais de cidade predominantes em São Paulo até 1920.

Segundo HOMEM (1984), o Martinelli inaugura em 1929 uma nova forma de apropriação do espaço urbano na Cidade de São Paulo. Para tanto, contribuiu a paulatina aceitação dos arranha-céus pelos técnicos e pelos paulistanos, a difusão do cálculo do concreto armado e a produção nacional de cimento em grande escala. A primeira indústria de cimento portland foi a Perus, que começou a produzir em 1926. Dez anos mais tarde iniciou sua produção a empresa Votorantim. No Brasil, o consumo de cimento mostrou-se em contínua ascensão, tendo se intensificado na década de 1930, quando a produção nacional superou as importações. A esta época, segundo LEME (2000), os escritos de Prestes Maia e Ulhôa Cintra indicavam que conceitos de urbanistas norte-americanos começavam a se perceber nas idéias predominantes do urbanismo paulista, verificando-se a introdução de critérios como o da racionalidade e eficiência na administração pública. 
Figura 41 - Novos modelos de cidade surgiam no início do século XX

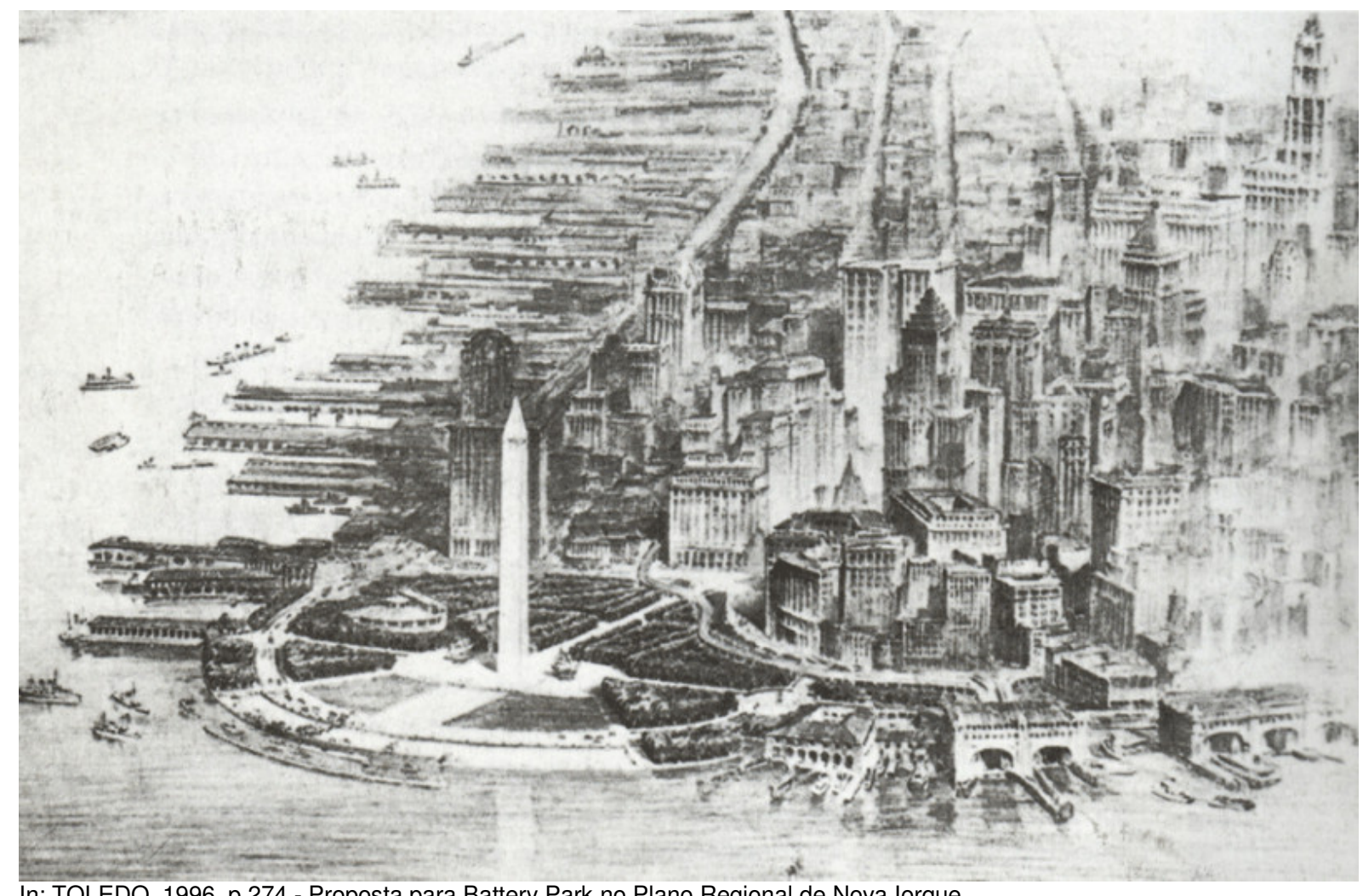

In: TOLEDO, 1996, p.274 - Proposta para Battery Park no Plano Regional de Nova lorque

A Lei no 2.611 de 1923, primeira lei de arruamento com visão urbanística (GROSTEIN, et al, apud FISCHER, 2005, p. 90), hierarquizou e redimensionou o sistema viário em toda a cidade; exigiu o custeio da implantação de ruas e infraestrutura pelos próprios loteadores, inclusive a conexão com as redes de vias existentes; caracterizou áreas inundáveis ou insalubres como não-urbanizáveis; estabeleceu dimensões e condições mínimas de ocupação dos lotes: lote mínimo de $300 \mathrm{~m}^{2}$; frente maior ou igual a $10 \mathrm{~m}$; fundo maior ou igual a $24 \mathrm{~m}$; construção principal do lote com ocupação máxima de $1 / 4$ da área do lote; recuos entre frentes e fundos de $18 \mathrm{~m}$ entre construções principais. Vale ressaltar que para o "centro" esta regra de dimensionamento mínimo dos lotes não teve condições de recaracterizar as quadras desta região, que já estavam loteadas, em sua maioria, na década de 1920. Verificou-se um avanço no âmbito da titulação de bens imóveis em 1928: o Brasil elaborou normas específicas regulamentando a co-propriedade por apartamentos de acordo com o Decreto Federal no 5.481. Conhecido como Lei de Criação de Condomínios, dispunha sobre a alienação parcial dos edifícios de mais de cinco andares (Batalha, apud SOMEKH, 1987, p.72). Vê-se esta lei como um avanço porque a partir deste momento os proprietários de imóveis passaram a enxergar o 
lote urbano de maneira diferente, pois empreendimentos imobiliários poderiam resultar do agrupamento de capital de mais de um indivíduo, sendo todos coproprietários da edificação e do lote. Supõe-se que a partir de então, mais recursos poderiam ser destinados a tais empreendimentos, visto que poderiam ser averbadas nas matrículas as parcelas de cada proprietário, assegurando o direito de usufruto dos novos espaços edificados.

Em função do complexo conjunto de leis urbanas criadas em São Paulo a partir de 1886, Sílvio Cabral de Noronha e Arthur Saboya foram os engenheiros incumbidos da revisão geral das leis municipais em vigor, criando um código municipal de obras, a Lei $n^{\circ} 3.427$ de 19 de novembro de 1929. Esta lei introduziu um zoneamento parcial na área objeto de estudo deste trabalho, o centro da cidade, com a construção compulsória de edifícios com mais de três pavimentos. Nota-se com esta medida o empenho dos legisladores em caracterizar a paisagem urbana desta região com base em uma volumetria mínima das edificações. Entende-se que esta norma pressupunha a criação de perspectivas urbanas a partir de vias ladeadas por edifícios em seus alinhamentos frontais, com fachadas seguindo os critérios da comissão de estética e com altura mínima comum.

O código de obras de 1929 configurou-se como uma compilação de leis específicas criadas a partir de 1886, repetindo basicamente as leis 2.332/20 e 2.611/23, tendo vigência até 1975 , sendo a princípio um modelo urbanístico abrangente e rígido. As pequenas alterações editadas após sua criação transformaram-no de acordo com as necessidades do mercado imobiliário. No "centro" da cidade - cujas leis serão mapeadas no próximo capítulo - incentivou-se a verticalização, mantendo-se o critério de alinhamento frontal obrigatório dos edifícios, à exceção de construções à Rua Barão de Limeira cujo recuo frontal deveria ser no mínimo de 6 metros; assim como construções na Avenida do Estado, entre a Rua da Moóca e Avenida Independência, e a Avenida Carlos de Campos, que deveriam ter recuo frontal mínimo de 10 metros. Foi mantida a Comissão de Estética como na Lei no 2.332/20, porém evidenciando que o estilo arquitetônico e decorativo seria livre. O artigo 151 definiu altura máxima de 50 metros para prédios e máximo de 10 andares além do térreo, às ruas Barão de Itapetininga, Xavier de Toledo, 7 de Abril, Conselheiro Crispiniano, 24 de Maio, Praças Ramos de Azevedo e República. Para as demais 
vias públicas, a altura máxima permitida seria 80 metros. Em seu artigo 554 estabeleceu que na zona central lotes teriam frente mínima de 10 metros, sendo que lotes maiores que $300 \mathrm{~m}^{2}$ teriam a edificação principal ocupando no máximo 1/3 da área do lote, enquanto lotes de $300 \mathrm{~m}^{2}$ teriam a edificação principal com projeção de $1 / 2$ da área do lote, sendo que haveria recuo de frentes e fundos de 16 metros entre edificações principais. Em ruas sem recuo obrigatório de construções a arborização só seria feita quando o passeio fosse maior ou igual a 4 metros, de acordo com 0 artigo 568.

Figura 42 - Divisão do Município de São Paulo: Lei no 3.427 de 1929

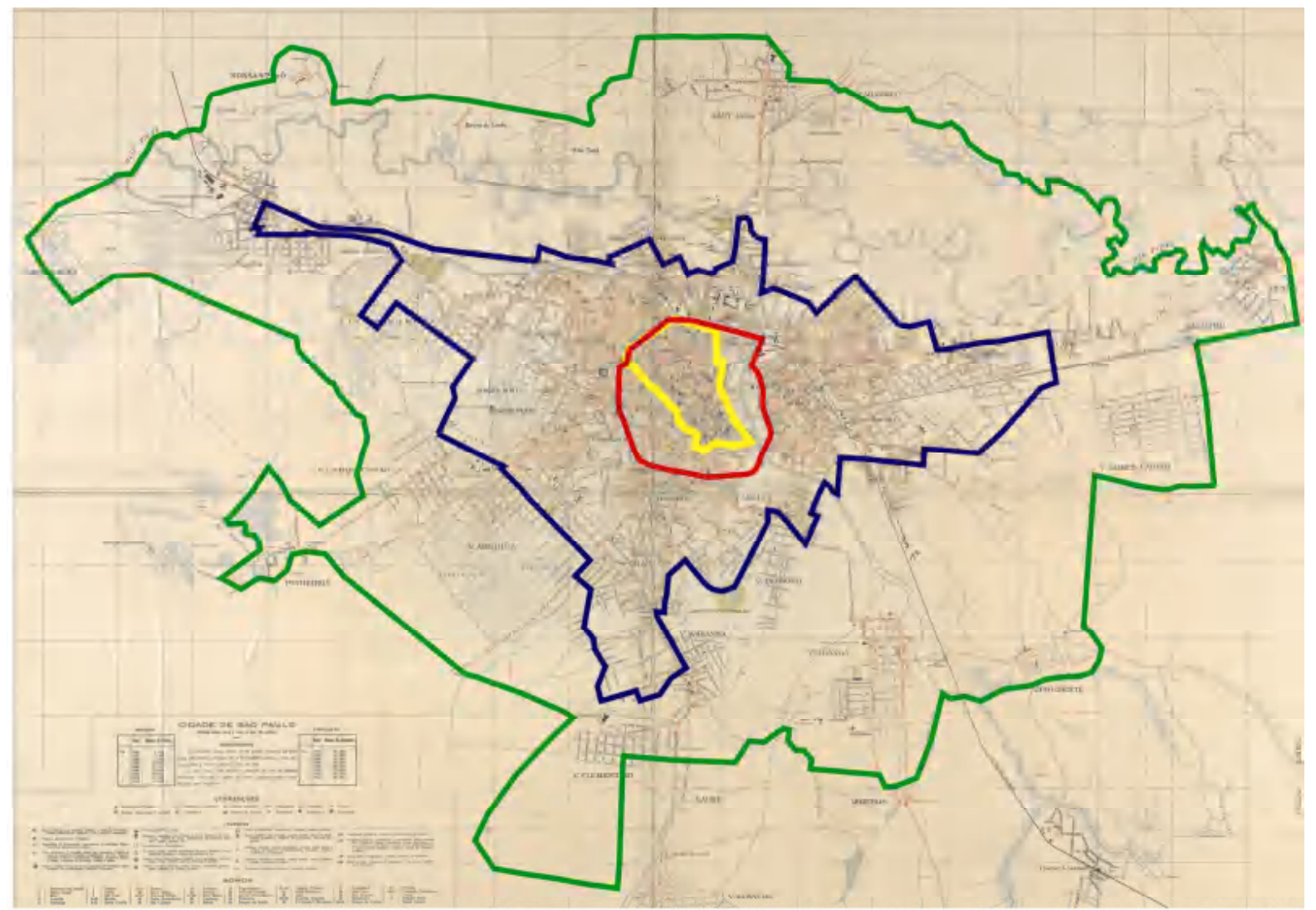

Fonte da planta base: Biblioteca Nacional do Rio de Janeiro. Org.: Eng. João Pedro Cardoso, chefe da Comissão Geográfica e Geológica (1914). FREITAS, R. Mapeamento das leis sobre a planta base, 2008. Formato JPEG.

Escala gráfica

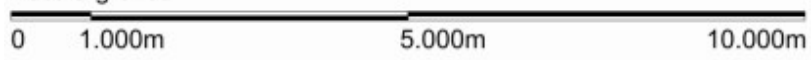

Perímetro de Estudo 
Figura 43 - Lei no 3.427 de 1929
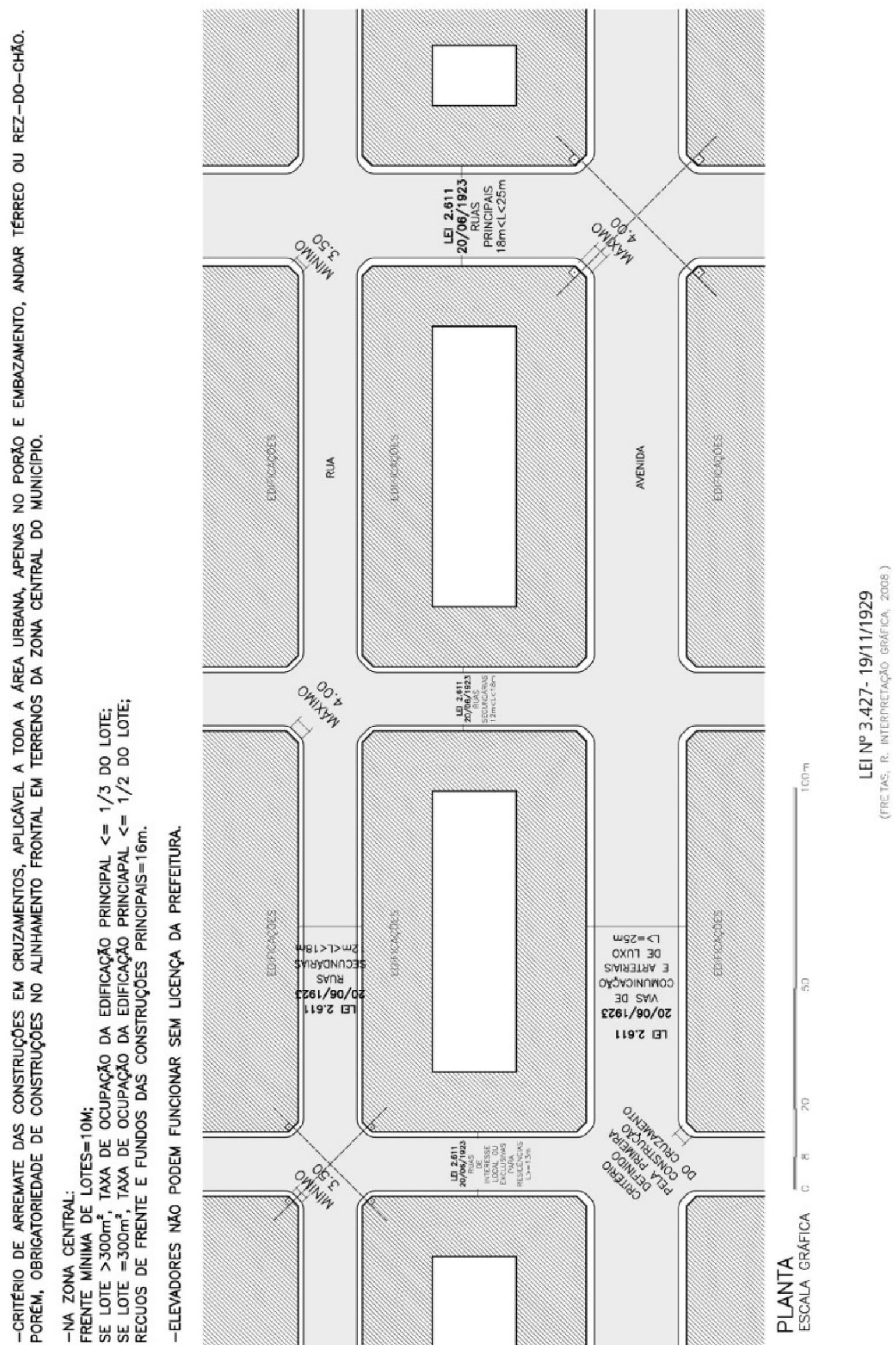
Em 1931, o prefeito Anhaia Mello instituiu novo zoneamento parcial em São Paulo pelo Ato $\mathrm{n}$. . 127, que definiu o uso residencial nos bairros implantados pela Companhia City; constituiu uma comissão para o estudo deste problema em toda a cidade; regulamentou a formação de núcleos comerciais; e do ponto de vista da legislação edilícia, introduziu alguns novos critérios: pé direito mínimo 3 metros para compartimentos de dormir; 2,5 metros para compartimentos de permanência diurna (e escritórios, por exemplo) e 4,0 metros para lojas. Para diversos autores, o engenheiro Luiz Inácio de Anhaia Mello foi um urbanista que empenhou grandes esforços para a consolidação do urbanismo no Brasil, articulando em sua atividade profissional a política e o ensino, introduzindo o ensino de urbanismo na Escola Politécnica. Segundo LEME (2000), entre 1927 a 1933, Anhaia Mello publicou no boletim do Instituto de Engenharia, diversos artigos que expunham experiências, principalmente norte-americanas, quanto à regulação e regulamentação urbana. Abordou em seus artigos formas de financiamento de obras por cobrança de taxas de melhoria, criação de instâncias de participação da comunidade no planejamento da cidade e a defesa da legislação urbanística, incluindo o zoneamento.

Entre 1930 e 1953, a cidade não elegeu mais seu prefeito, que era indicado pelo interventor. Em 1934, a nova Constituição Federal consagrou a justiça eleitoral, criada em 1932; reforçou os poderes do Congresso; previu formas de intervenção do Estado na economia e direitos sociais; introduziu o mandado de segurança, para garantia de direitos certos e incontestáveis contra atos inconstitucionais ou ilegais. Parte desse período corresponde à vigência do Estado Novo (10/10/1937 a 29/10/1945). A Câmara Municipal de São Paulo não funcionou até 1947. Na Ditadura Vargas, a legislação reduziu alturas no Centro Velho (localizado no atual distrito Sé), definiu alturas mínimas para construções da Avenida Ipiranga, regulamentou recuos, usos e alturas ao longo da Avenida 9 de Julho (normas que serão detalhadas mais adiante e mapeadas no capítulo 5) e decretou zoneamento do Jardim América e Pacaembu incorporando à legislação municipal as restrições contratuais da Cia. City, de acordo com ROLNIK (2003).

O Ato nำ 663 de 1934 aprovou a consolidação do Código de Obras (Arthur Saboya), Lei no 3.427 de 1929, basicamente mantendo-a quanto aos critérios aplicados ao "centro". Manteve o recuo mínimo frontal para as avenidas marginais ao 
Tamanduateí, da Rua da Moóca até Avenida Teresa Cristina e recuo de 10 metros na Avenida Dom Pedro I. Manteve critério de altura da edificação em função da largura da via, assim como a Lei ํo 2.332/20, mas permitiu acréscimo de altura quando seguido critério de escalonamento:

Figura 44 - Ato no 663 de 1934
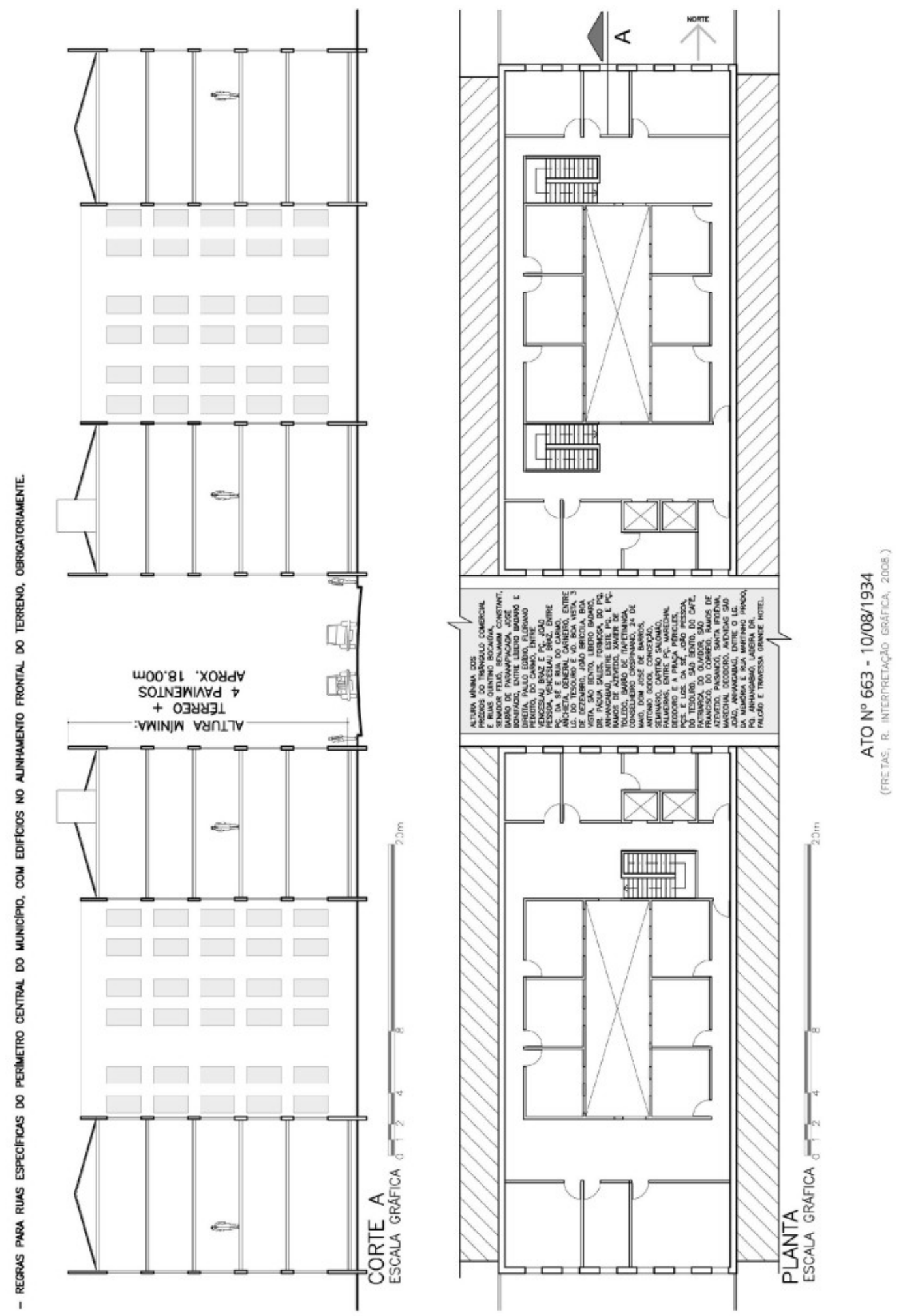
Figura 45 - Ato no 663 de 1934

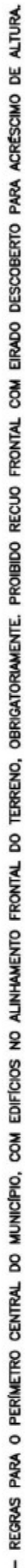

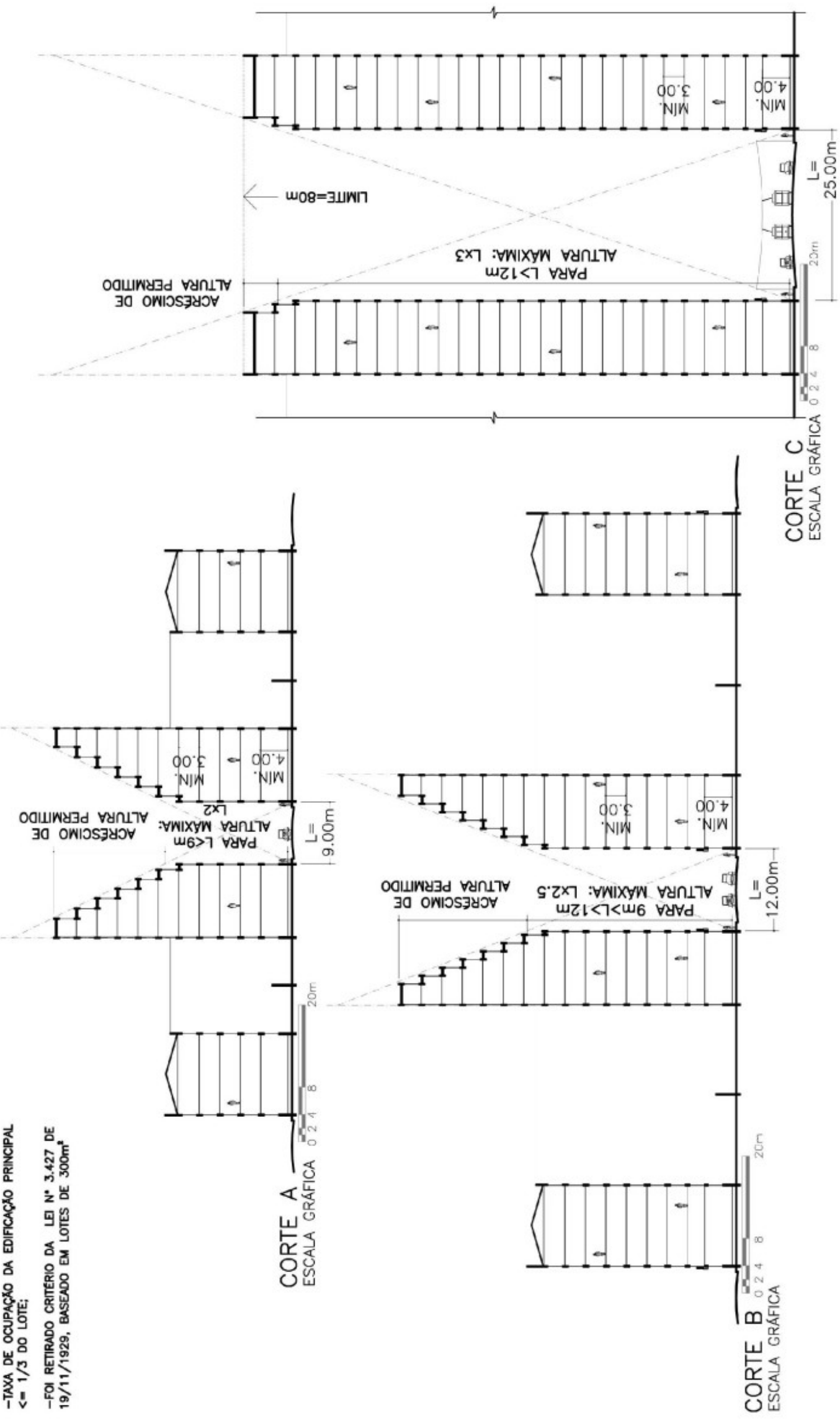


Na Lei no 2.332/20 já havia critério mínimo para insolação exigida de uma hora para edifícios existentes antes de 1920 e, dali em diante, de três horas de insolação. $\mathrm{Na}$ Lei no 3.427/29 copiou-se o texto, portanto, uma hora para edifícios existentes antes de 1929, contradizendo a lei anterior quanto aos edifícios construídos a partir de 1920, que deveriam ter três horas de sol no dia mais curto do ano osculando, dentro da rua, saguões ou corredores, o plano do respectivo piso. Neste Ato ํo 663/34 foi mantido o referido critério de insolação referenciando a Lei de 1929, desta vez, escrito corretamente. $\mathrm{O}$ artigo 172 deste ato ressaltou que o estilo arquitetônico ou decorativo seria livre, desde que não se opusesse ao decoro e às regras fundamentais da arte de construir. Recusando-se projetos em flagrante desacordo com preceitos básicos da arquitetura. Criou premiação anual para arquitetos e proprietários em exposição anual de fachadas. Vê-se a intenção de uniformização de critérios estéticos nas fachadas frontais dos edifícios, o que reflete conceitos mantidos em busca da caracterização de perspectivas urbanas uniformes e homogêneas, como resultado das edificações construídas em lotes privados ao longo das vias.

No entanto, a mesma lei de 1929 introduz um conceito contraditório a esta intenção esteticizante citada supra, permitindo que edifícios atingissem 80 metros de altura. Como tais edifícios poderiam ser construídos sobre os alinhamentos laterais e deveriam compulsoriamente ser erguidos sobre o alinhamento frontal do terreno, percebe-se por esta contradição da lei que os legisladores não vislumbraram a necessidade de introduzir-se critério estético para as fachadas laterais dos novos prédios. Por outro lado, talvez tenham imaginado que não caberia regulamentar uma fachada que depois seria recoberta pela construção vizinha. Constata-se que, conforme imagens expostas no capítulo 5 e no anexo 1, a paisagem urbana do "centro" é bastante marcada pelas fachadas laterais de edifícios, percebe-se que os legisladores, em 1929, não previram este resultado, fruto de uma contradição de conceitos presentes na lei deste mesmo ano, conhecida como Código de Obras Arthur Saboya - cuja vigência se deu até 1975. 
Figura 46 - Ato no 663 de 1934
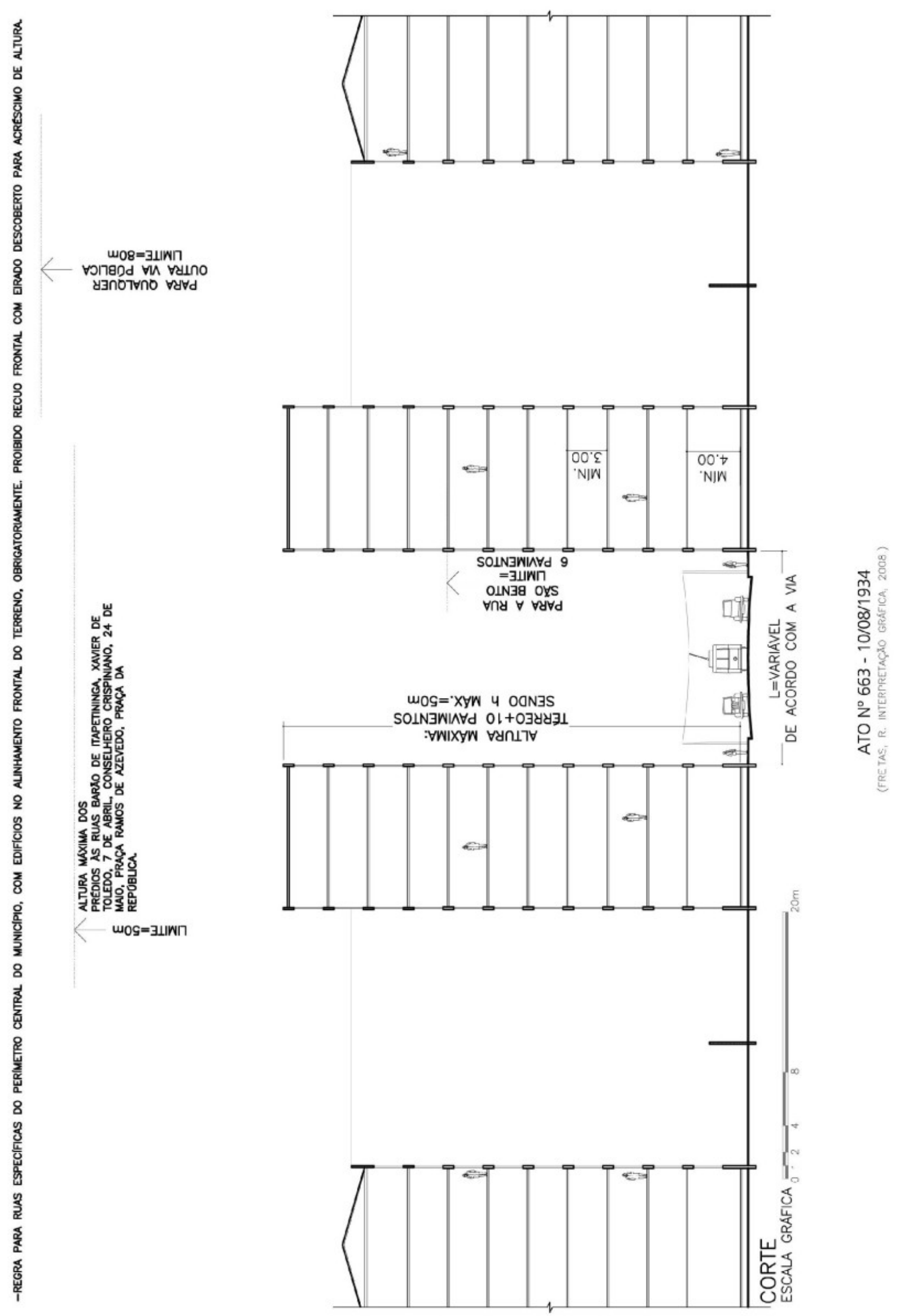
O artigo 180 do código de obras de 1934 (Ato no 663/34) definiu altura mínima de 4 pavimentos, mais térreo, para prédios do Triângulo Comercial e ruas Quintino Bocaiúva, Senador Feijó, Benjamim Constant, Barão de Paranapiacaba, José Bonifácio, entre Líbero Badaró e Direita, Paulo Egídio, Floriano Peixoto, do Carmo, entre Venceslau Braz e Praça João Pessoa, Venceslau Braz, entre Praça da Sé e Rua do Carmo, Anchieta, General Carneiro, entre Largo do Tesouro e viaduto Boa Vista, 3 de Dezembro, João Brícola, Boa Vista, São Bento, Líbero Badaró, Dr. Pádua Sales, Formosa, do Parque Anhangabaú, entre este parque e Praça Ramos de Azevedo, Xavier de Toledo, Barão de Itapetininga, Conselheiro Crispiniano, 24 de Maio, Dom José de Barros, Antonio Godói, Conceição, Seminário, Capitão Salomão, Palmeiras, entre a Praça Marechal Deodoro e a Praça Padre Péricles; Praças e Largos da Sé, João Pessoa, do Tesouro, São Bento, do Café, Patriarca, do Ouvidor, São Francisco, do Correio, Ramos de Azevedo, Paissandu, Santa Ifigênia, Marechal Deodoro; Avenida São João, Anhangabaú, entre o Largo da Memória e a Rua Martinho Prado; Parque Anhangabaú; Ladeira Dr. Falcão e travessa Grande Hotel. De acordo com o artigo 182, a alameda Barão de Limeira, entre a Praça Júlio de Mesquita e Rua Helvetia, teria edificações sem recuo frontal e maiores que 3 pavimentos, porém no restante da alameda, o recuo frontal mínimo seria de $6 \mathrm{~m}$, sem critério mínimo de pavimentos. No próximo capítulo são localizadas em planta as regulamentações para vias específicas.

O Ato $n^{\circ}$ 663/34 definiu rígidos critérios de segurança para elevadores, bem como diversos tipos de fábricas e critérios de instalação, retirou a base de $300 \mathrm{~m}^{2}$ para a exigência de ocupação máxima de $1 / 3$ do lote pelas construções principais, mantendo apenas o critério máximo de $1 / 3$ para qualquer lote. Vale ressaltar que nesta pesquisa, com base nos 30 projetos estudados, não foi evidenciada a aplicação deste critério de proporção da ocupação do lote em no máximo 1/3 pela edificação principal. Verificou-se que os projetos executados no período de vigência deste critério, no "centro" da cidade, em geral ocuparam o lote em aproximadamente 90\% da área, não sendo edificados apenas nas áreas dos poços de ventilação interna. A título de exemplo das características semelhantes encontradas nos projetos estudados, no anexo 1 , serão expostos 4 projetos edificados no período de vigência deste critério. 
O alargamento da Rua Xavier de Toledo foi aprovado pela Lei no .2 .332 de setembro de 1920, e revigorado pelo Ato $n \times$ 969, de dezembro de 1935. A nova largura de 25 metros se deu pela desapropriação dos imóveis do lado par das ruas Xavier de Toledo e Consolação. De acordo com LEFÈVRE (2006), as obras de alargamento se desenvolveram de 1936 até 1937. Neste mesmo ano a nova Constituição Federal reduziu a autonomia dos Estados; estabeleceu o sufrágio indireto na eleição da Câmara dos Deputados e do Conselho Federal (Senado); criou o Conselho da Economia Nacional e alargou os poderes do Presidente da República, o qual passou a ser eleito por 6 anos por um colégio de eleitores designados pelas câmaras municipais, pelo Conselho da Economia Nacional e pelo Parlamento. Verificava-se na cidade de São Paulo, neste período, a construção de prédios de habitações coletivas ou múltiplas. A lei $\mathrm{n}^{\circ} 3.571$ de 1937 surgiu para regulamentar estas construções em ruas cujas características predominantes apresentavam-se como residenciais. Seu principal objetivo foi proteger as condições de habitabilidade dos imóveis do tipo residencial-particular, que se estabeleceram em determinadas ruas e em conjunto de ruas formando zonas residenciais bem caracterizadas. LEFEVRE (1951) comparou essa lei com a New York Multiple Dweling Law, verificando os moderados objetivos da lei paulistana, que limitou-se a determinar para um número restrito de ruas o afastamento dos edifícios de apartamentos em relação à frente das demais divisas, inclusive a de fundo, tendo ignorado, o legislador, a necessidade de proporcionar espaços livres anexos para melhor arejamento e insolação dos compartimentos, bem como para recreio dos moradores, principalmente crianças. Porém, estas regulamentações urbanas não foram aplicadas ao "centro" da cidade.

O Ato no. 1.366, de 19 de fevereiro de 1938, teve como objetivo estabelecer gabaritos de altura a ruas do Centro Novo - localizado no atual distrito República formando desenho característico. Determinava a altura não mais em proporção à largura da rua, como prescrevia o Código, mas em relação ao número de pavimentos. Na Rua São Bento, o número de pavimentos máximo era 6 . Nas ruas Barão de Itapetininga, Xavier de Toledo, 7 de abril, Conselheiro Crispiniano, Marconi, 24 de maio, nas Praça Ramos de Azevedo e da República deveria ter, no alinhamento frontal, 10 pavimentos com $3 \mathrm{~m}$ de pé direito, além do térreo. Acima desta altura, os prédios deveriam atender o artigo 145 do Ato ํㅡ 663 de 1934. Nas 
ruas Marconi e Xavier de Toledo, em lote de frente menor que $20 \mathrm{~m}$, os edifícios deveriam manter linhas arquitetônicas alinhadas às linhas dos lotes lindeiros.

Figura 47 - Ato no 1.366 de 1938

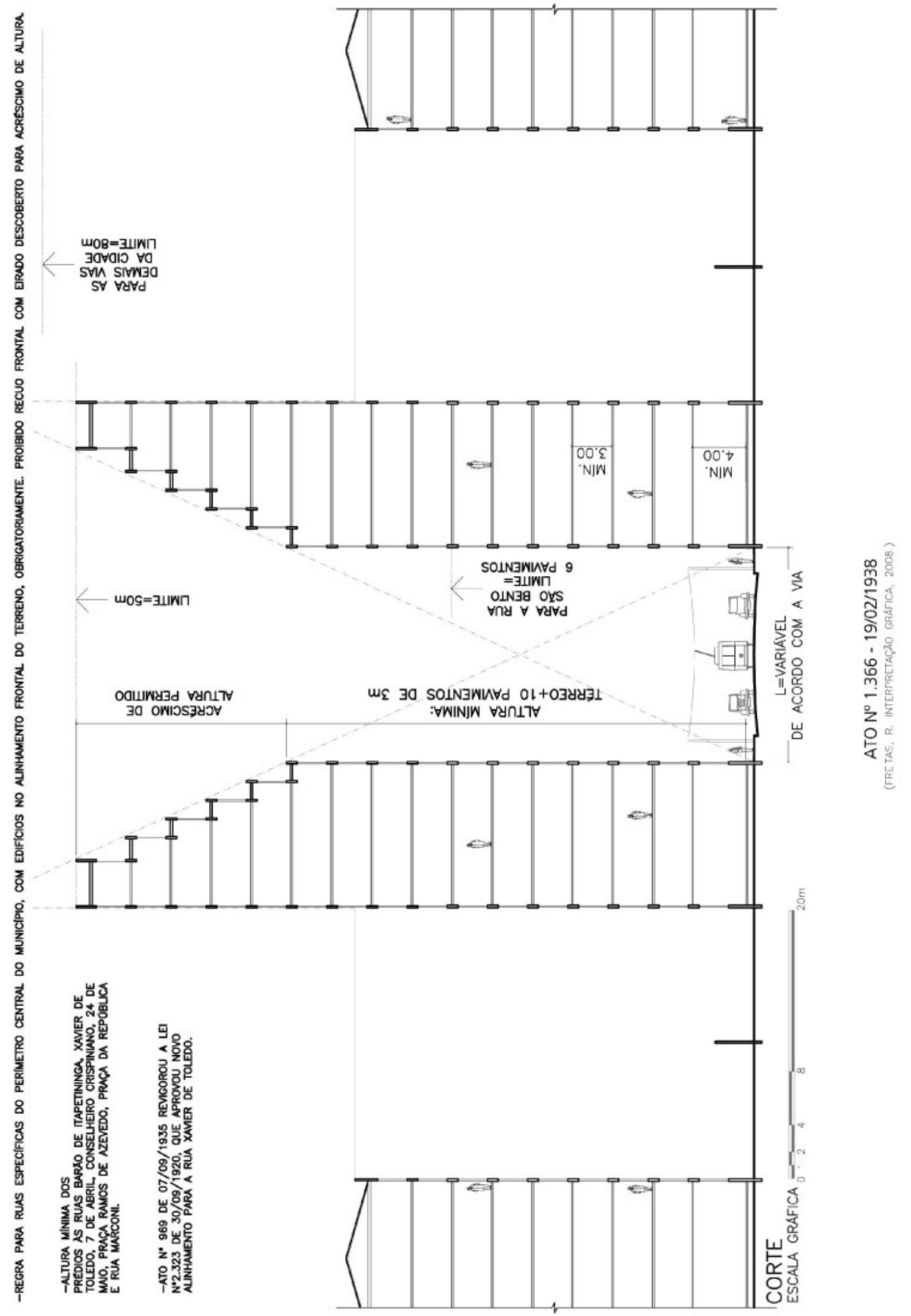


Com o Ato no. 1.470 de 1938, o prefeito Prestes Maia introduziu mudanças na legislação, limitou gabaritos em algumas ruas do centro, definindo novo desenho urbano. Esta busca de controle estético previa a manutenção da usual contigüidade de fachadas frontais entre edifícios vizinhos, formando conjuntos arquitetônicos. Por este ato estabeleceu um "Plano de Melhoramentos Urbanos" para diversas ruas do chamado "Centro Novo", com o alargamento das ruas Ipiranga, São Luiz e Viera de Carvalho; alargamento e prolongamento da Rua Epitácio Pessoa; prolongamento das ruas Marconi e Major Sertório com ampliação das pracinhas de remate.

Segundo LEME (2000), a partir da década de 1940, a configuração do Departamento de Urbanismo Municipal estruturou-se de forma mais sólida, deixando-se de lado a idéia de comissões desvinculadas da estrutura administrativa da prefeitura. Ainda de acordo com esta autora, Anhaia Mello defendeu a implantação deste departamento vinculado ao prefeito diretamente e propôs uma comissão consultiva do plano da cidade, também subordinada ao prefeito, que seria composta por cidadãos de reconhecida competência que, sem remuneração, exerceriam consultoria para a elaboração do plano da cidade.

O Decreto-lei no 41 de1940 definiu que a via entre as ruas Conceição e Consolação seria a Avenida Ipiranga, resultante do alargamento da Rua Ipiranga, com prolongamento até a Praça da República e alargamento parcial da Rua Epitácio Pessoa até a Rua da Consolação, em conformidade com o Ato no 1470/38. Este Decreto-lei estabeleceu 39 metros como altura mínima obrigatória de prédios à Avenida Ipiranga, no alinhamento, até 1950, caso contrário resultaria em acréscimo de $20 \%$ no imposto predial. Podendo crescer até 52 metros se recuados em 2,5 metros a partir dos 39 metros de altura. Podendo crescer ainda até 115 metros de altura se recuados 4,5 metros do alinhamento a partir dos 52 metros de altura. Edifícios em esquinas maiores de 30 metros poderiam chegar a 135 metros de altura. Esta lei permitiu, para edifícios à Avenida Ipiranga, o uso de marquises abrigando o térreo mais sobreloja (altura total de 8 metros), configurando-se como um recuo em relação ao alinhamento frontal. Em seu artigo $8^{\circ}$, permitiu a construção de edifícios com fachadas únicas em mais de um lote, independentemente das divisões internas correspondentes a cada propriedade. O artigo 9e estabeleceu que, em edifícios com mais de 20 pavimentos, haveria "reentrância pública" no térreo 
maior ou igual a 1/3 da frente do lote com profundidade maior ou igual a 3,5 metros e área maior ou igual a $30 \mathrm{~m}^{2}$. Havia também incentivo à abertura do térreo como área pública em edifícios sem o corpo super-elevado.

Em 1941, o Decreto-Lei no 75, de 11 de fevereiro, regulamentou as construções dos lotes da Av. 9 de Julho, em três diferentes trechos: A, B e C. O trecho "A" inclui-se na área deste trabalho, desenvolvendo-se do Largo da Memória até o Viaduto Martinho Prado, para o qual pode-se dizer que instituiu-se um zoneamento de usos permitidos: comercial, restrito a instalação de lojas de "aspecto condigno com a natureza e importância da via". Proibindo-se carvoarias, quitandas, similares e lojas de materiais "grosseiros e mesquinhos", bem como fábricas ou oficinas, estabelecimentos antiestéticos, ruidosos ou incômodos. Com recuo mínimo de frente igual a 4 metros, podendo o térreo ser alinhado, porém sem saliências. No trecho " $A$ " poderia se construir contiguamente sendo que, em construções isoladas, o recuo lateral seria maior ou igual a 2 metros e as fachadas laterais deveriam ter o mesmo tratamento da fachada frontal. Com altura mínima compulsória de 29 metros, os edifícios poderiam chegar a 80 metros, desde que escalonados em 1 para 3 metros a partir do 29 metros de altura. Nesta via permitiu-se também a construção de uma única edificação em vários lotes. A partir dos 29 metros de altura todas as edificações seriam recuadas em 2,5 metros, até 45 metros, altura a partir da qual fazia-se obrigatório o recuo de 4,5 metros no trecho A. Este Decreto-lei definiu que os lotes teriam frente mínima de 12 metros e que as exigências de recuos não seriam obrigatórias para o 1ำ quarteirão da avenida, entre o Largo da Memória e a Rua João Adolfo.

Com o Decreto-Lei nº. 92 de 1941, o prefeito Prestes Maia introduziu alterações no Código de Obras de 1934, revisando o limite das alturas na área abrangida pelo perímetro de irradiação. Alterou o perímetro da zona central estabelecido pelo Código, ampliando os limites de altura máxima na zona central para 40 metros, nas ruas com até 12 metros de largura; 60 metros nas ruas de largura igual ou maior que 12 metros e até 18 metros; de 80 metros nas ruas de largura superior a 18 metros, estendendo a altura mínima obrigatória, de 39 metros (11 pavimentos, incluindo-se o térreo), às seguintes vias públicas: Avenida São João, da Praça Antonio Prado até a Rua Duque de Caxias, Largo Paissandu, Praça Júlio Mesquita, Largo do Arouche, 
Praça da República (incluindo ruas de contorno da Escola Normal), Vieira de Carvalho e ligação com Avenida São João (Rua General Osório), São Luiz (Praça da República à Rua da Consolação). Altura mínima de 22 metros, ou 6 pavimentos (inclusive o térreo), na Praça Alexandre Herculano (Largo do Arouche, parte inferior); Avenida São João, da Rua Duque de Caxias à praça Marechal Deodoro; Praça Marechal Deodoro, Avenida General Olímpio da Silveira; Avenida Padre Péricles; Largo São Francisco; Avenida Rangel Pestana, da Praça da Sé ao Largo da Concórdia; Largo da Concórdia, nos novos trechos da avenida de irradiação: Rua Senador Queiroz; prolongamento da São Luiz em direção ao Viaduto Jacareí; Rua Maria Paula e seu prolongamento, nova avenida entre a Avenida Brigadeiro Luiz Antonio e Praça João Mendes; praça João Mendes, Ruas Irmã Simpliciana e Anita Garibaldi, Praça do Futuro Paço e Rua Mercúrio.

Para LEFEVRE (1951), as leis que permitiam o escalonamento para atingir as alturas máximas, inspiradas nos zoneamento americano, incentivaram o crescimento em altura para edifícios de escritórios, incentivados pela valorização das propriedades. Em 1946, com a saída de Getúlio Vargas, o Brasil entrou em uma nova ordenação política, com a Constituição Federal deste mesmo ano, que retomou as bases da Constituição de 1934. Na economia, manteve-se o processo de desenvolvimento da indústria, fortemente impulsionado durante o Estado Novo, ao mesmo tempo em que o país procurou inserir-se na nova ordenação econômica mundial do pós-guerra.

De acordo com LEME (2000) o Decreto-Lei no 431 de 07 de julho de 1947 criou a Comissão Orientadora do plano da cidade. Desta maneira, quando solicitado pelo executivo ou legislativo municipal, a comissão formada por representantes do executivo, do legislativo, das universidades e de entidades profissionais, tinha por objetivo apreciar projetos relativos ao plano da cidade e aos serviços de utilidade pública, podendo também apresentar estudos e sugestões relativos aos problemas de urbanismo. Este decreto não só criou o Departamento de Urbanismo, mas também os de Arquitetura e de Obras Públicas. 
Figura 48 - Decreto-Lei no 41 de 1940

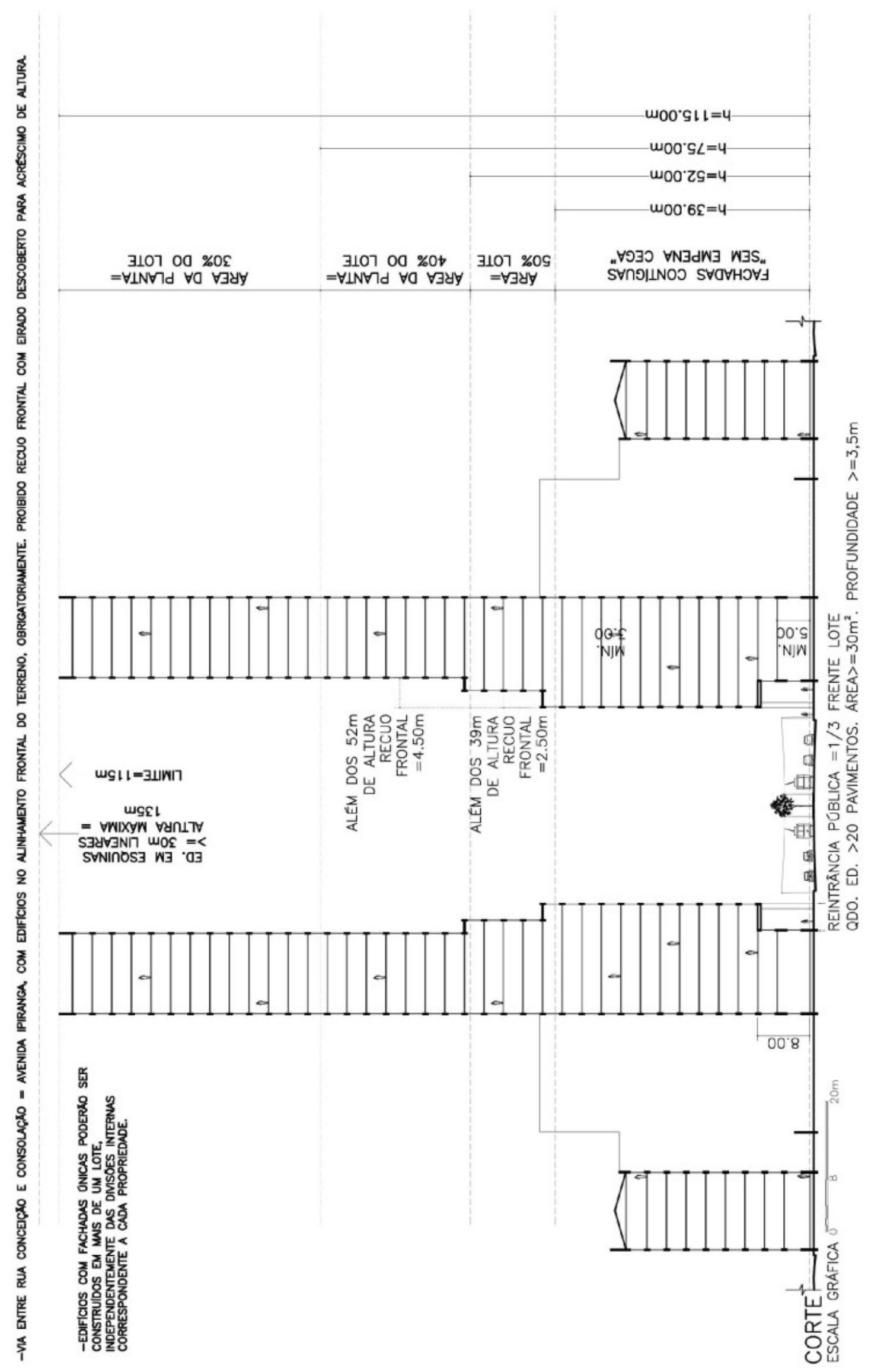


Figura 49 - Decreto-lei no 75 de 1941

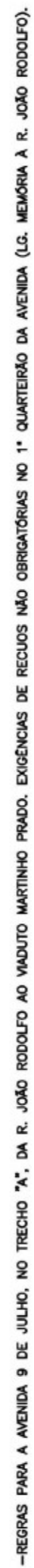

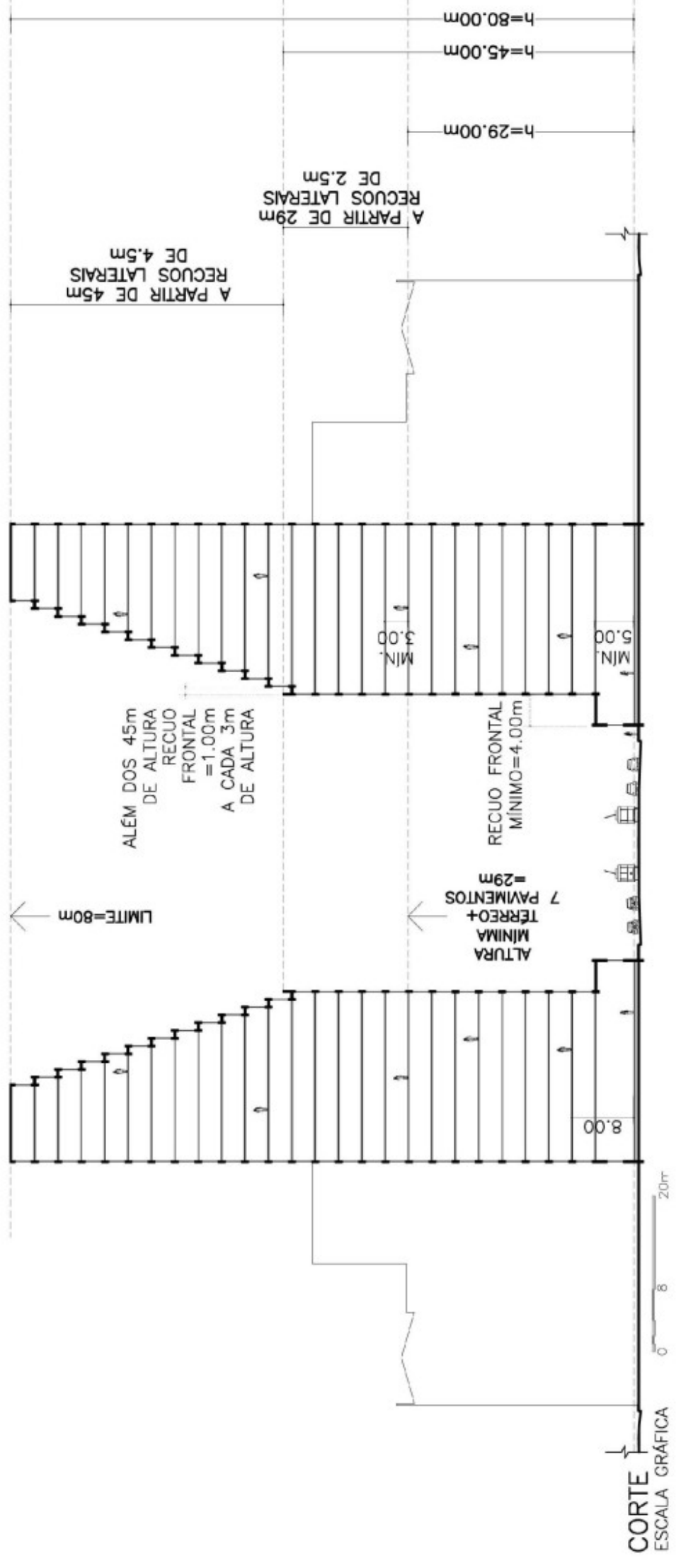


Figura 50 - Decreto-Lei no 92 de 1941

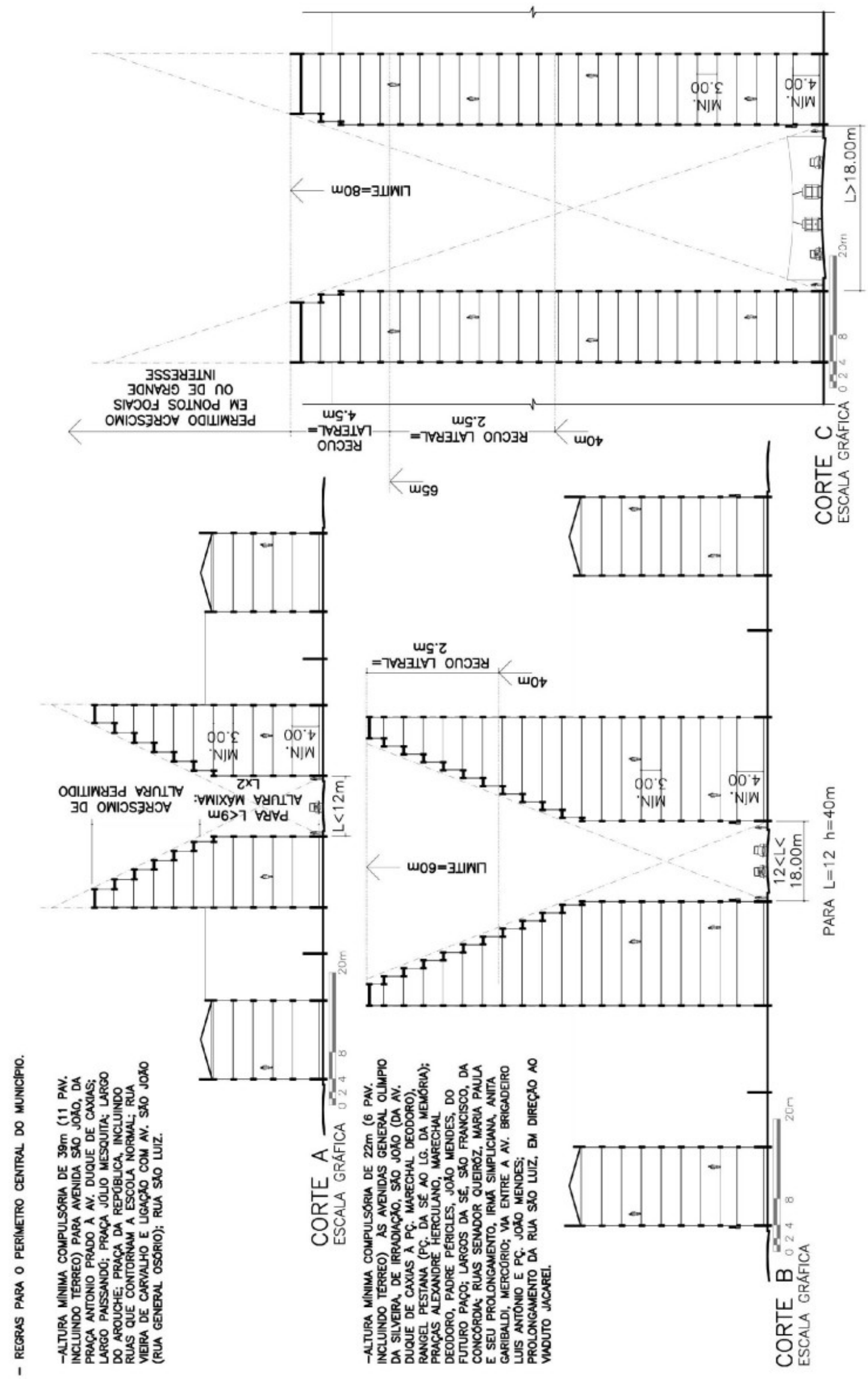


Ainda de acordo com LEME (2000), após 1947 o planejamento urbano passou a ser um trabalho de um grupo de técnicos - pertencentes aos quadros da carreira de funcionário público - que a partir de então passaram a exercitar de maneira crescente seu conhecimento técnico em propostas de legislação urbanística. Nesse período, no Departamento de Urbanismo da Prefeitura de São Paulo, foram feitas as primeiras propostas para uma legislação de zoneamento desta cidade, que serão expostas mais adiante. Sete anos depois, a comissão do plano da cidade é colocada em atividade, com a Lei $n^{0}$ 4.494, de 1954, apresentando a primeira proposta de plano para São Paulo.

Com a Lei no 4.615 de 1955, foram aprovadas modificações significativas no Código de Obras de 1934, reorganizando-o. Foram aprovadas novas disposições, com a revogação de regulamentações e introdução de condições gerais de edificações e normas executivas de construção. Em seu Artigo 1ํaㅁ aprovaram-se os capítulos do Código de Obras relativos a edificações, correspondendo aos seguintes itens: 4) Condições gerais das edificações; 5) Edificações para fins especiais; 6) Execução da construção. Em seu Artigo 2ํㅡㄹ definiram-se os capítulos do Código de Obras em elaboração pela Prefeitura Municipal de São Paulo: 1) Generalidades; 2) Zoneamento; 3) Arruamentos e loteamentos. Em seu artigo 4ํㅜㅇ criou-se a Comissão Permanente do Código de Obras.

Segundo ZMITROWICZ (1979), pela Lei n 4.805 de 1955, até que se aprovasse o zoneamento mais completo, a cidade foi dividida dentro do município nas seguintes zonas, com suas respectivas características:

- estritamente residenciais (proibida instalação de estabelecimentos industriais);

- predominantemente residenciais (permitida instalação de pequenas indústrias);

- mistas (permitida instalação de estabelecimentos comuns);

- fabris (permitida instalação de todo tipo de indústria, adotando-se precauções que, a juízo da prefeitura, afastassem a possibilidade de incômodo à vizinhança). 
Em outubro de 1954, a comissão orientadora do Plano Diretor do Município de São Paulo enviou à câmara de vereadores o projeto de Lei ํㅡ 458 , em busca de controlar o crescimento desordenado da cidade e a expansão imobiliária (SOMEKH, 1987, p.106).

Na gestão Adhemar de Barros foi aprovada a Lei 5.261/57 (projeto de Lei 458/54), regulamentada pelo Decreto № 3.776 de 1958, que definiu um Coeficiente de Aproveitamento máximo 6 (C.A. - relação entre as áreas construída e do terreno) para as edificações comerciais; C.A. 4 para residências e hotéis; densidade líquida para edifícios de habitação coletiva: 600 pessoas/ha, sendo o critério de 2 pessoas para 1 dormitório, 3 para 2, 5 para 3 e 7 pessoas para 4 dormitórios, calculando-se a partir da área do lote mais a faixa até o eixo da rua lindeira (menor ou igual a $8 \mathrm{~m}$ ); sendo no mínimo $35 \mathrm{~m} 2$ de terreno correspondente por habitação.

Prestes Maia enviou à Câmara dos Vereadores, em abril de 1965, um projeto de lei propondo a alteração da lei № 5.261 de 1957. Tal projeto previa a equiparação do coeficiente 6 para as edificações comerciais e residenciais. Garagens e edifícios com pilotis não teriam sua área computada na área total a ser aprovada, podendo chegar a um máximo de três vezes a área do lote, além do coeficiente 6 já permitido. O projeto previa ainda ampliação para 8 do coeficiente de aproveitamento do lote para hotéis ou hospitais, e ampliação do coeficiente para 15, quando em edifícios destinados a estacionamento de veículos em função do aumento do número de veículos na cidade àquela época. O prefeito Faria Lima aprovou em 1966 junto à Câmara Municipal, a Lei ํㅡ 6.877, que definiu o coeficiente máximo seis para todos os usos em toda a cidade. Revogando as exigências de densidade e espaços livres de arruamento anteriormente estabelecidos pela Lei oㅜ 5.261/57 (mínimo $20 \mathrm{~m}^{2}$ por habitante para recreio público em loteamentos, de acordo com Atos ㄲo 663/34 e 3.776/58), bem como revogando a cota mínima de terreno (maior ou igual a $35 \mathrm{~m}^{2}$ de área correspondente do lote para cada habitação em loteamentos). 
Figura 51 - Decreto no 3.776 de 1958

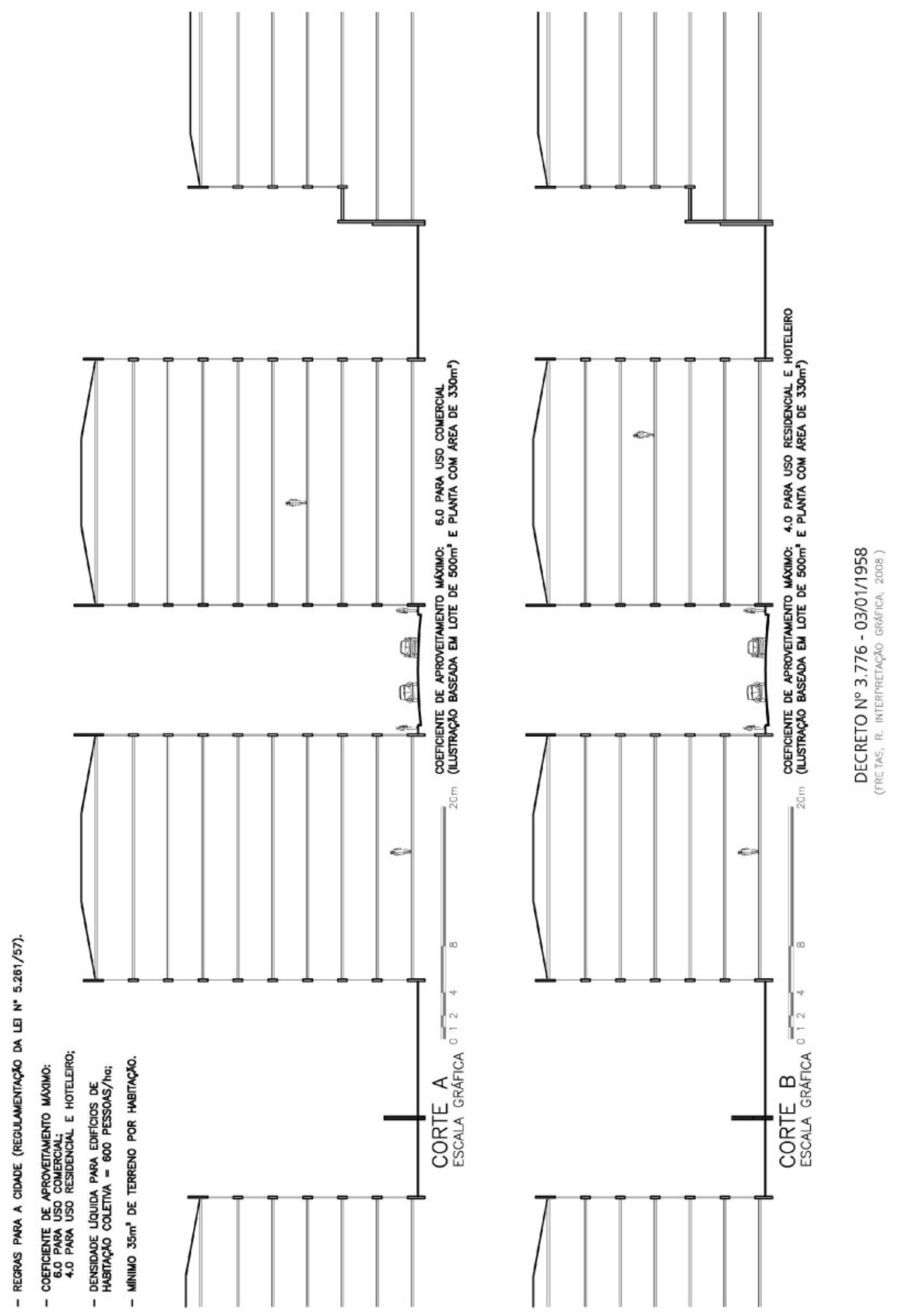


Figura 52 - Lei no 6.877 de 1966

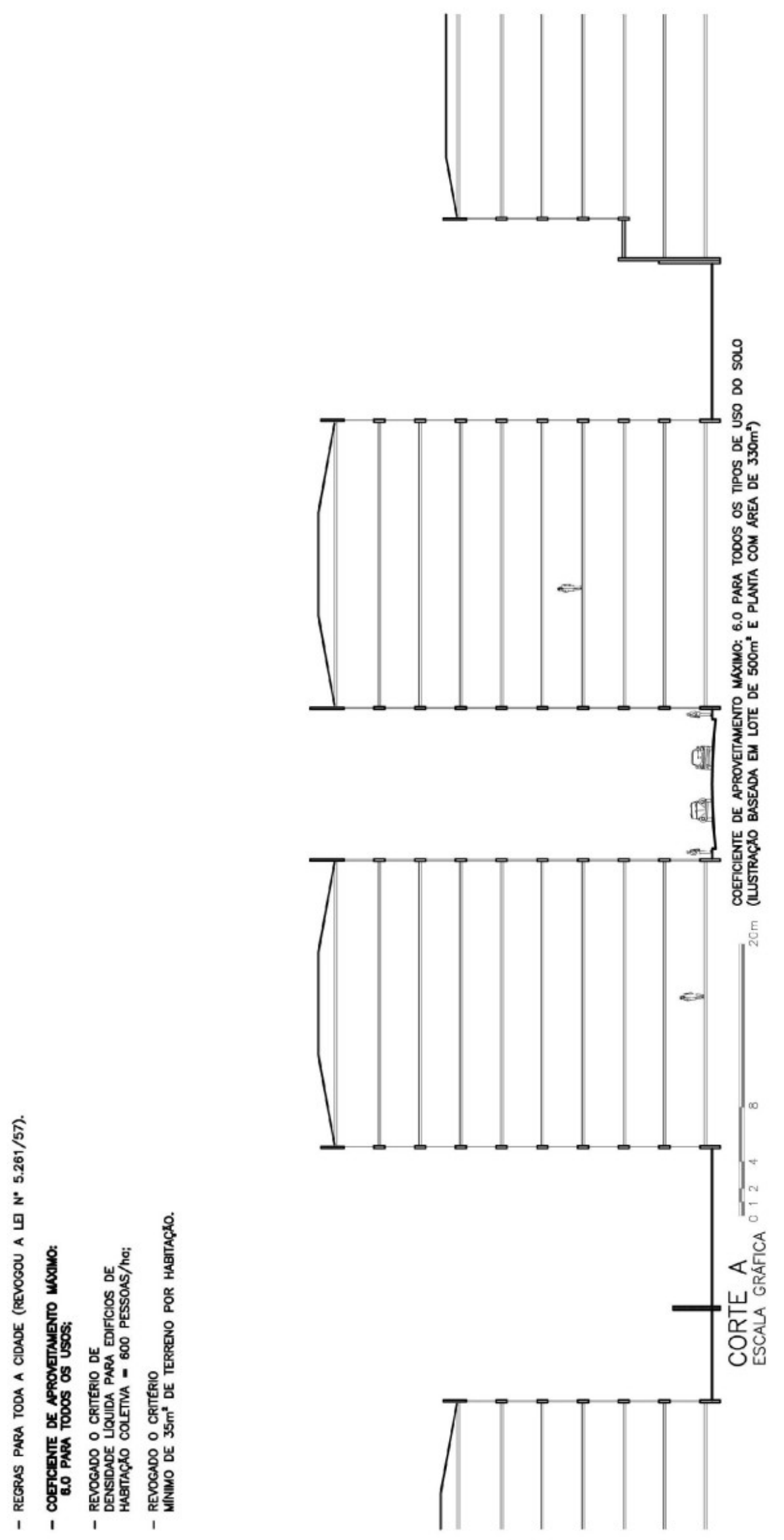


Definiu-se desta maneira, após 1966, uma nova regra para as construções em lotes privados. De acordo com ROLNIK (2003), essa regra seria modificada somente em 1971, durante a gestão de José Carlos Figueiredo Ferraz, quando o Plano Diretor de Desenvolvimento Integrado (P.D.D.I.) definiu como limite máximo para aproveitamento de um terreno o coeficiente de quatro vezes sua área.

A Constituição Federal de 1967 integrou os Atos Institucionais e os seus atos complementares, que após a revolução militar de 1964 foram criados a fim de concentrar o poder no Presidente da República. Alterada em 1969, esta Constituição aumentou o poder financeiro da União, reforçou o Poder Executivo, definiu a eleição do Presidente por sufrágio indireto (colégio composto pelos membros do Congresso e por representantes dos Estados), estendeu a justiça militar, prefixou o sistema partidário, estabeleceu a noção de segurança nacional. Neste período de nova reorganização política nacional, em São Paulo, com o Decreto nํㅜ6.766/66 e a Lei no 7.191 de 1968 foram criadas as administrações regionais e se iniciaram os estudos e obras do metropolitano paulistano (WAKISAKA, 1989, p.46). Estudos anteriores para o metropolitano foram realizados pela Comissão do Metropolitano, criada em 1955, coordenada por Prestes Maia, que participou da elaboração do projeto. Vê-se que aproximadamente 80 anos após a proclamação da República, pelo artigo 157 da Constituição Federal de 1967, abordou-se e definiu-se o termo "área metropolitana". Neste momento da história da cidade de São Paulo, buscaram-se soluções administrativas e de transporte urbano a fim de lidar com as escalas de questões urbanas advindas das grandes proporções da sociedade paulistana, tanto em relação à sua população, quanto à sua área urbanizada. Segundo MEYER (1991), em 1967 foi criado o "Conselho do Desenvolvimento da Grande São Paulo" e o "Grupo Executivo da Grande São Paulo - GEGRAN", responsável por enfrentar os problemas urbanos paulistanos de uma perspectiva metropolitana, visando estabelecer uma integração tanto administrativa quanto operativa da área da Grande São Paulo, porém, segundo esta mesma autora, alcançando poucos resultados.

Em 1968, foi elaborado pela Prefeitura do Município de São Paulo o Plano Urbanístico Básico (P.U.B.), estudado no âmbito da região metropolitana, em busca de alternativas para o desenvolvimento urbano da cidade, avaliando-as principalmente em termos de eficiência do sistema de transporte a implantar no 
futuro (ZMITROWICZ, 1979, p.140). Estava presente no P.U.B. a crença de que seria possível resolver o problema de transportes de São Paulo com uma extensa malha de vias expressas e com uma também extensa rede metroviária, equilibrando a saturada estrutura viária radio concêntrica existente. Apesar das medidas recomendadas no P.U.B. não terem sido implantadas, elas tiveram a capacidade de orientar o desenvolvimento do "Plano Metropolitano de Desenvolvimento Integrado de São Paulo" (P.M.D.I.), em 1970; do Plano Diretor Viário, que estabeleceu diretrizes para o sistema de vias expressas, em 1971; e do Plano Diretor de Desenvolvimento Integrado de São Paulo (P.D.D.I), de 1971.

O P.M.D.I. procurou identificar os principais problemas fora do controle dos governos locais, nos setores de uso do solo, transporte e saneamento. Desaconselhou a expansão urbana na direção sul e sudoeste, reorientando-a em direção a leste, com o intuito de preservar da poluição a área das represas (ZMITROWICZ, 1979, p.144).

Além da fixação de diretrizes gerais, padrões e metas para o Plano de Ação do Governo Municipal, o P.D.D.I. dividiu o território em "unidades territoriais", com classificação de área, de uso do solo e tipos de zonas a serem implantadas posteriormente pela lei de zoneamento. Ainda segundo ZMITROWICZ (1979), as "unidades territoriais" seriam de três níveis. A unidade territorial de nível 1 ou local, com área entre 100 e 200 hectares e raio de aproximadamente 500 a 700 metros, seria delimitado por vias arteriais, correspondendo à área atendida por equipamentos como creche, parque infantil, ensino infantil e de primeiro grau, parque de vizinhança. A unidade territorial de nível 2, constituída de agregação de duas ou mais unidades de nível 1, seria atendida por um centro comunitário e de orientação familiar, com praça pública e campo esportivo. As unidades territoriais de nível 3, constituídas de agregação de duas ou mais unidades de nível 2, normalmente delimitadas por vias expressas, corresponderiam às administrações regionais em que se dividia o município até a criação das subprefeituras. O Plano Diretor Viário, parte integrante do P.D.D.I., previu mais de 100 quilômetros de avenidas, pretendendo transformar, de forma mais radical, a estrutura viária da cidade de radial para ortogonal, baseando-se no automóvel como meio de transporte. 
Na visão de GIAQUINTO (1995), estando os interesses das empreiteiras de obras públicas, da indústria automobilística e do capital industrial contemplados no Plano de Vias Expressas, as faixas mais privilegiadas da população precisavam de um discurso para a cidade como tudo que fundamentalmente atendesse a dois conjuntos de interesses: a preservação dos bairros residenciais, onde morava grande parte da elite paulistana; a preservação e perenização de ganhos do mercado imobiliário no quadrante sudoeste da cidade, transformando o zoneamento no fator mais importante de formação de preços. O Plano de Vias Expressas não foi consolidado em função de problemas políticos e financeiros.

Em 1972, a Lei 7.805 - Legislação de Parcelamento, Uso e Ocupação do Solo (L.P.U.O.S.) - criou as zonas Z1 a Z6 e Z8, para as quais foram definidas as seguintes variáveis de ocupação do solo: frente mínima; área mínima; recuos mínimos; taxa de ocupação (a relação entre projeção da edificação sobre a área do terreno- T.O.); coeficiente aproveitamento (relação entre o total de área construída sobre a área do terreno - C.A.); limite de altura (gabarito); recuos especiais; vagas de estacionamento de veículos e pátio de manobra para carga e descarga; número máximo de pavimentos; e profundidade do corredor de uso especial. De acordo com GIAQUINTO (1995), esta lei de zoneamento, foi fruto de conflitos entre interesses de diversos agentes sociais e econômicos. Promulgada após uma lei de anistia - pela qual edificações saíram do cadastro de imóveis irregulares e passaram ao cadastro de imóveis regulares, independente de terem sido construídos de acordo com a legislação - a L.P.U.O.S. possuía:

- zonas residenciais (estritamente residencial de baixa densidade populacional - os bairros jardim; predominantemente residencial de baixa, média e alta densidade);

- zonas industriais (predominantemente e exclusivamente industrial);

- zona predominantemente comercial e de prestação de serviços;

- zonas especiais, até a zona rural, que seriam objeto de planos e projetos específicos. 
Foram definidas na Lei $7.805 / 72$, as categorias e subcategorias de uso listadas no anexo 2. A área delimitada nesta pesquisa pertencia às seguintes zonas:

Z2 - uso predominantemente residencial, com T.O. <0,5 e C.A. $<1$;

Z3 - uso predominantemente residencial, com T.O. <0,5 e C.A. $<2$;

Z5 - uso misto, com T.O. < 0,8 e C.A. < 3,5;

Figura 53 - Zoneamento na área em estudo: 1972

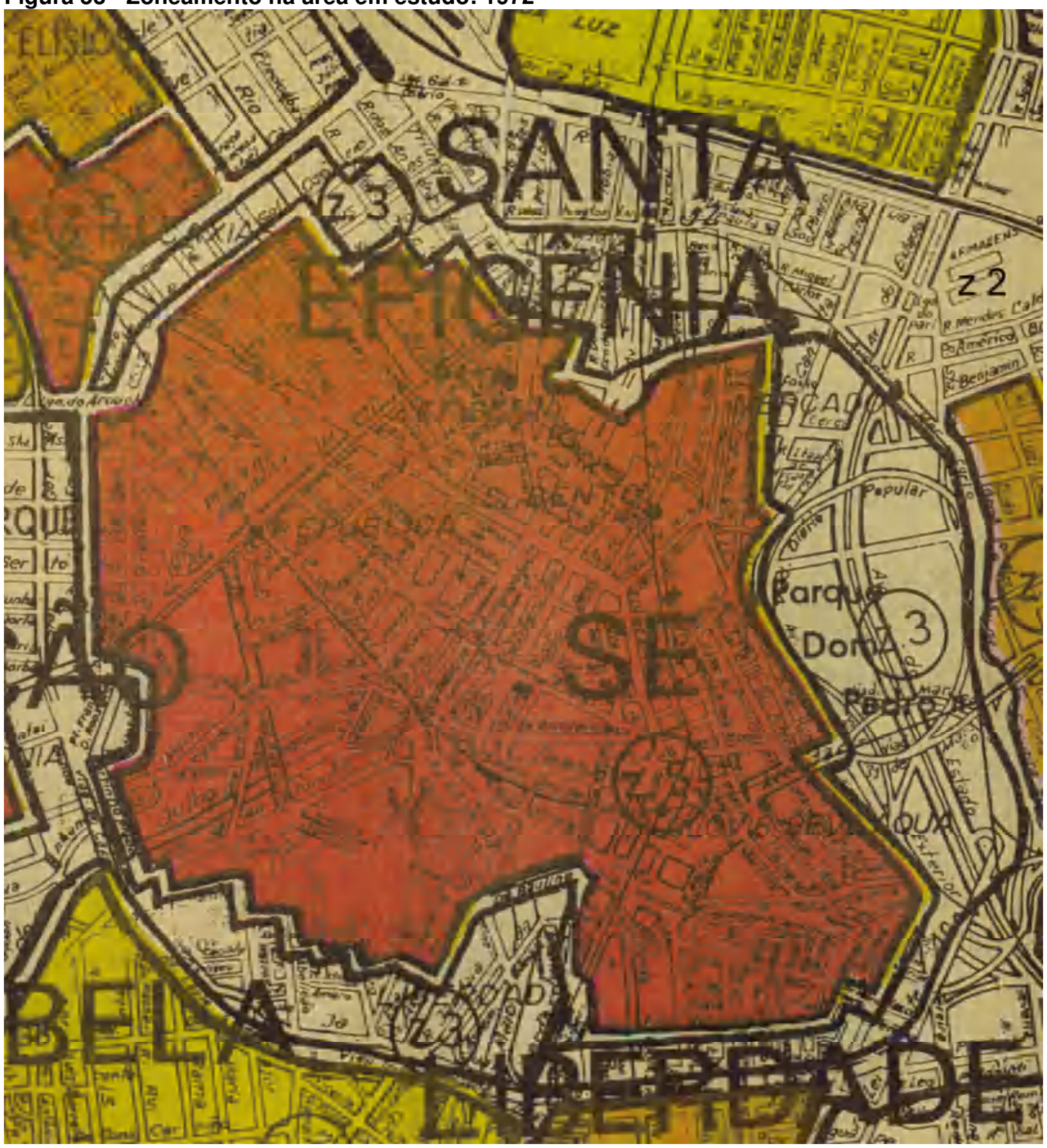

Folha de São Paulo, novembro/1972, edição especial, 2ª edição. O Novo Zoneamento da Capital. Elaboração: equipe especializada da Folha de São Paulo, com base na lei em um mapa cedido pela Geomapas Editora de Mapas e Guias Ltda. 
Figura 54 - Lei no 7.805 de 1972 - Z2

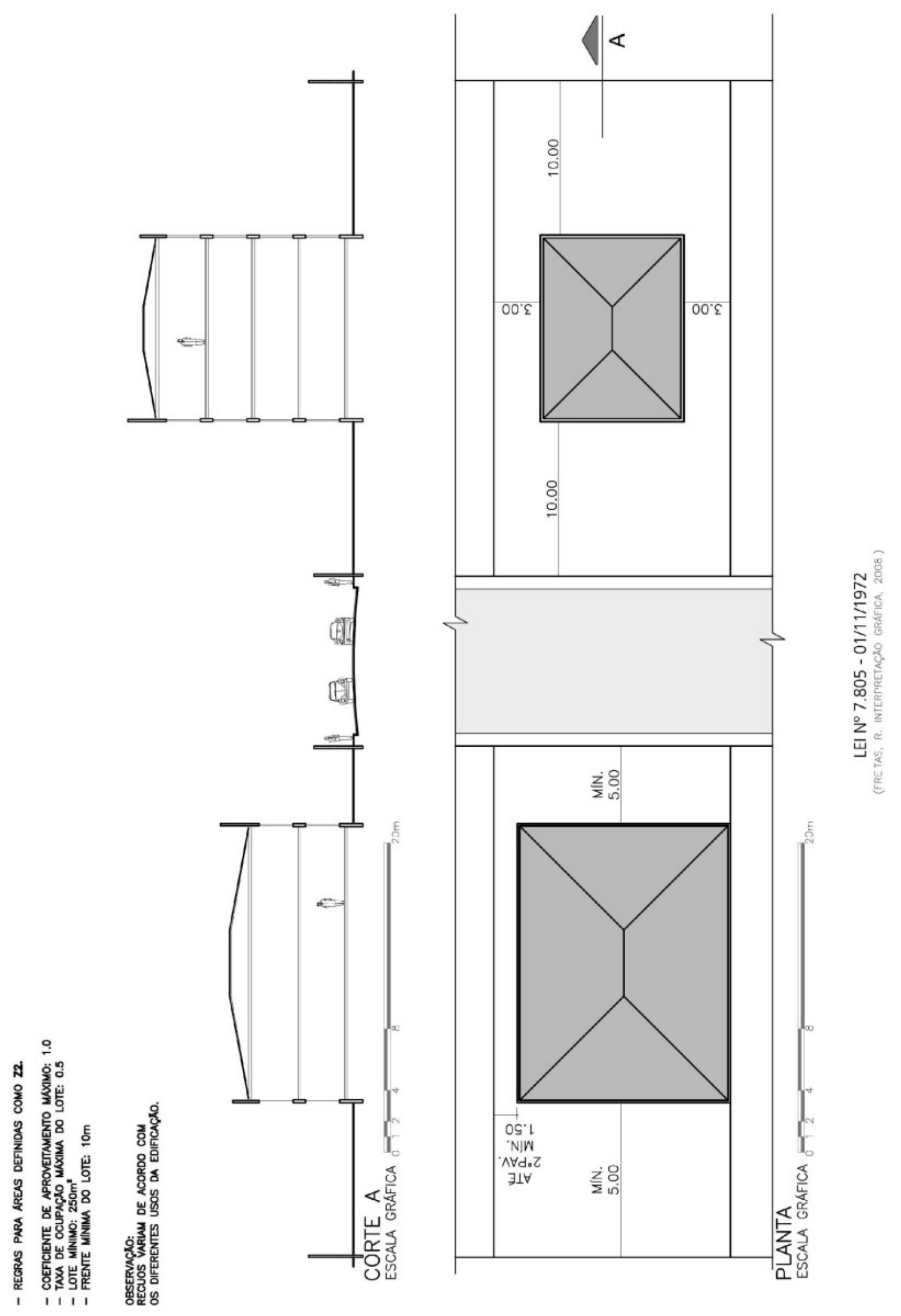


Figura 55 - Lei no 7.805 de 1972 - Z3

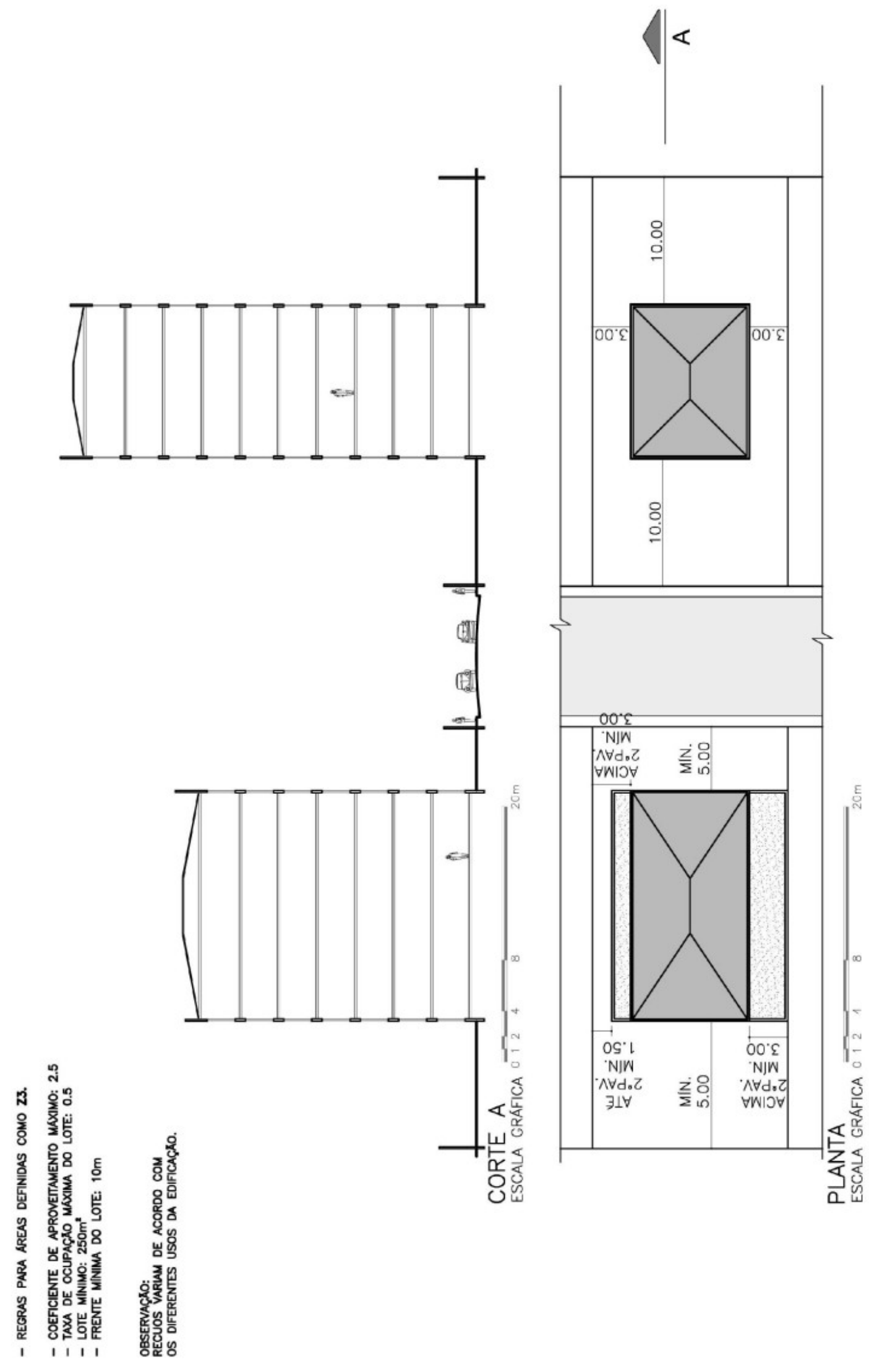


Figura 56 - Lei no 7.805 de 1972 - Z5

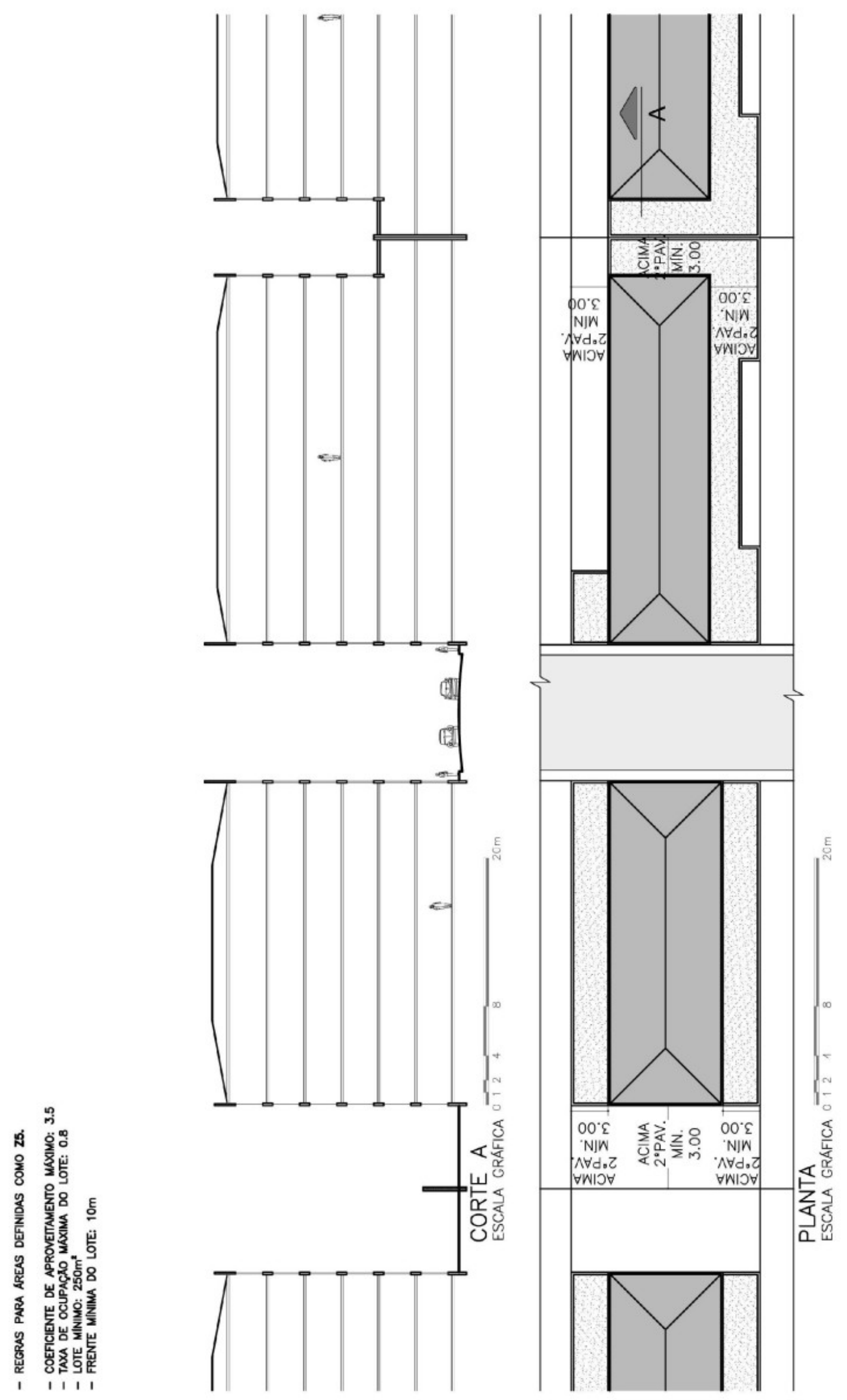


Figura 57 - Lei no 7.805 de 1972 - Z5

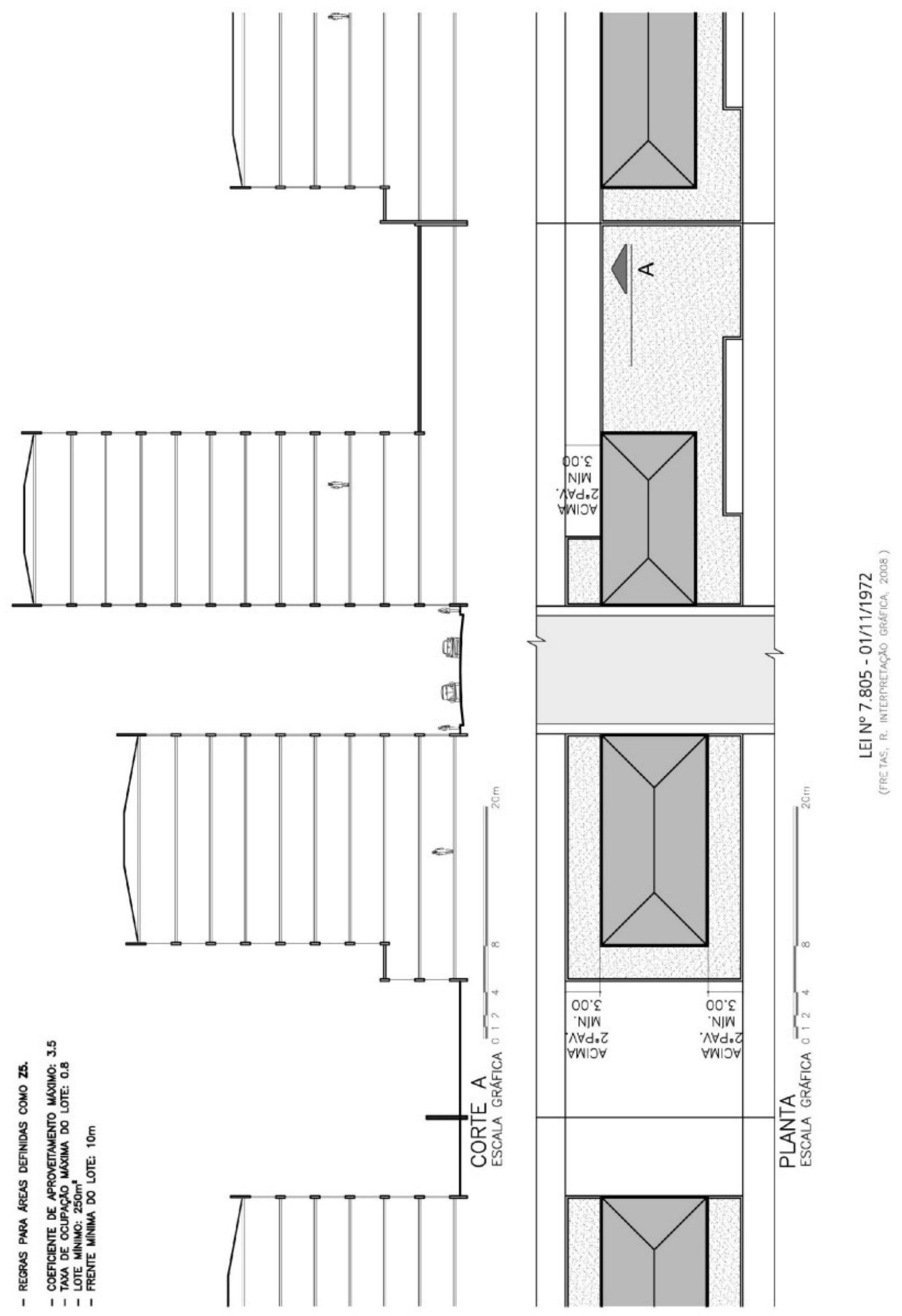


Têm-se abaixo os coeficientes de aproveitamento máximos (C.A.), presentes na Lei no 8.001 de 1973 - criada por Benjamin Adiron Ribeiro - que configuraram-se em função da zona e do tipo de uso do solo, cujas definições detalhadas compõem o anexo 2 deste trabalho:

- C.A. 2 para uso residencial R3 em Z2;

- C.A. 4 para uso residencial R2.2 e R3 em Z3, Z4, Z5;

- C.A. 4 para uso de serviços S2 e institucional E2, em Z3, Z4, Z5;

- C.A. 4 para uso comercial C2, C3 em Z3, Z4, Z5;

- C.A. 4 para uso de serviços $\mathrm{S} 2.9$ em Z2;

- C.A. 4 para uso institucional E3 e de serviços S3 em Z3.

Pelos dados acima, verifica-se que no perímetro estudado nesta pesquisa o coeficiente de aproveitamento máximo do solo seria basicamente de quatro vezes a área dos lotes, a partir de 1973, a não ser no caso de uso residencial na pequena parcela a norte do perímetro estudado, que teria C.A. 2. Deste modo, o limite de C.A. 3,5 previsto pela lei de 1972 passou a C.A. 4 no ano seguinte

Segundo GIAQUINTO (1995), o texto da Lei Adiron de 1973 resumiu-se a uma série de alterações da L.P.U.O.S. de 1972, visando minimizar seus impactos, aperfeiçoando-a e ajustando-a. Em 1973 criaram-se as zonas de uso Z8-AV8 e AV9, que englobaram áreas verdes de clubes, e propuseram-se compatibilizações com a Comissão de Zoneamento do Município de São Paulo, composta por representantes da municipalidade, do mercado imobiliário e de entidades de setores afins (Conselho Regional de Engenharia, Arquitetura e Agronomia, Instituto de Arquitetos, Instituto de Engenharia, entre outros). Um ano depois, o Decreto no 11.106/74 repetiu a estrutura do texto da L.P.U.O.S. de 1972, consolidando as leis criadas de 1972 a 1974, regulamentando e detalhando-as. Este decreto introduziu subcategorias de uso, com os desenhos explicativos de recuos em lotes com condições e formas peculiares. A Lei no 8.328 de 1975 tratou do parcelamento, uso e ocupação do solo em zonas Z8 e criou novas zonas de uso, ampliando o número de zonas que compunham a legislação urbanística em São Paulo (GIAQUINTO, 1995, p.68).

Vale aqui uma breve consideração a respeito da legislação urbana analisada neste capítulo e sua relação com o perímetro urbano em estudo (atuais distritos Sé e 
República). O código Arthur Saboya vigiu de 1929 a 1975. Os edifícios construídos na Área Central até 1972 não tinham a obrigatoriedade dos recuos laterais, à exceção de algumas leis em vias específicas, como por exemplo, a já citada Avenida 9 de Julho; não tinham exigências para o recuo de frente, critério mantido também após 1972; áreas reservadas para equipamentos coletivos em obras de lotes privados não eram exigidas; a obrigatoriedade de ajardinamento do lote não existia até 1972 , data em que estabeleceu-se $80 \%$ como a área de projeção máxima de edificações que fossem erguidas em lotes do "centro" da cidade.

Surgiu em 1975 a Lei no 8.266, o Código de Edificações. Segundo GIAQUINTO (1995), este código constituiu-se como uma evolução do Código de Obras Arthur Saboya e não como um novo modelo. Após sua criação foram necessárias muitas alterações. Seu objetivo foi separar suas atribuições edilícias das atribuições urbanísticas do zoneamento de 1972, apesar de algumas não terem sido separadas, por exemplo: a proibição da existência de várias modalidades de usos mistos permitidos pelo zoneamento e a determinação de recuos além dos previstos, mais adequados à manutenção da salubridade nas edificações. Verificou-se a presença constante de sobreposições e contradições legais nas leis urbanas paulistanas do século XX, como por exemplo, a já citada contradição da Lei no 3.427 de 1929, quanto à busca da homogeneização da paisagem urbana - baseada em edificações contíguas sem recuo frontal - concomitantemente à permissão da verticalização de tais construções sem definição do critério da taxa de ocupação dos lotes, até 1972.

Vale ressaltar que nesta pesquisa foram estudados 30 projetos edificados em lotes privados no "centro" de São Paulo e serão expostos, no anexo 1, os 10 exemplares escolhidos como evidências de características comuns entre os projetos estudados. Dentre os projetos de 1923 a 1972 não verificou-se a aplicação de três normas:

- ocupação máxima de $1 / 4$ da área do lote pela construção principal, de acordo com a Lei $\mathrm{n}^{\circ} 2.611$ de 1923;

- ocupação máxima, pela edificação principal, de 1/3 da área de lotes maiores que $300 \mathrm{~m}^{2}$ ou de $1 / 2$ da área de lotes menores que $300 \mathrm{~m}^{2}$, de acordo com a Lei $\mathrm{n}^{\circ} 3.427$ de 1929; 
- ocupação máxima, pela edificação principal, de $1 / 3$ da área de qualquer lote, de acordo com o Ato no 663 de 1934;

Apesar das três regulamentações supracitadas definirem a proporção máxima entre a área de projeção da construção e a área do lote, esta relação deveria ser obedecida pela edificação principal do lote. Pressupõe-se que haveria mais de uma edificação neste lote, visto que uma delas seria a principal. Entende-se que, se um lote poderia ter mais de uma edificação, o critério de projeção máxima da edificação no terreno não era claro, pois qual seria a ocupação máxima permitida para as demais edificações construídas na mesma propriedade? Esta proporção não estava explícita na legislação urbana até 1972, assim como não estava definida a projeção do lote que poderia ser ocupada somando-se todas as suas edificações.

A partir das leis expostas até aqui e da constatação da não aplicação das três normas citadas acima, nos projetos estudados de 1923 a 1972, percebe-se que a questão do adensamento urbano do "centro" de São Paulo, até 1972, foi tratada pela legislação urbana sem a regulamentação explícita da proporção entre a área de projeção do edifício sobre a área do lote. Pode-se entender que o ensino de urbanismo - iniciado no início do século XX na Escola Politécnica e consolidado nas faculdades de arquitetura em meados da década de 1960 - não se refletiu de maneira contundente na legislação urbana paulistana até 1972. Constata-se que a cultura técnica da edificação fez-se presente na legislação urbana enquanto legislação edilícia por todo o século XX. Porém, conceitos urbanísticos apresentaram-se em leis esparsas e de modo pontual ao longo do século passado, consolidando-se apenas em 1972 na legislação urbana enquanto legislação urbanística.

Antes da continuação da exposição das leis do século $X X$, vale ressaltar outro aspecto subjacente à legislação urbana paulistana pesquisada neste trabalho, a indefinição de critérios de dimensionamento dos lotes do "centro". De acordo com a planta da cidade exposta no capítulo 2, um levantamento de V. Huet de Bacellar que evidencia os lotes urbanos de terra definidos no "centro" desde 1893, parcela relevante do perímetro estudado já estava loteada no século XIX. Os critérios de lotes mínimos que surgiram nas leis da década de 1920, já mencionados 
anteriormente, não se refletiram nos lotes do "centro" da cidade. Constatou-se que as leis urbanas paulistanas foram criadas, ao longo de cem anos após a proclamação da República, com base em critérios de ocupação dos lotes que foram amadurecendo, do ponto de vista técnico, seguindo conceitos urbanísticos predominantes no meio técnico internacional neste período. Um destes conceitos, discutido por Victor da Silva Freire por volta de 1913, e aplicado às leis da década de 1920 foi o de lote mínimo de terra, ou seja, em função dos conceitos urbanísticos predominantes e das técnicas edilícias conhecidas à época, definiu-se a parcela mínima de terra a ser urbanizada, sobre a qual seria possível erguer uma edificação. A partir de 1929, constatou-se pelas leis expostas neste trabalho que a manutenção compulsória da contigüidade e alinhamento frontal das fachadas principais dos edifícios, a determinação de sua altura e de suas áreas internas mínimas de ventilação e insolação estabeleceram-se com base em lotes regulares, do ponto de vista de suas proporções em relação aos lotes mínimos estabelecidos por lei. Porém, as proporções e dimensões dos lotes centrais não seguem os critérios urbanísticos amadurecidos ao longo do século XX, conforme evidenciado na planta exposta no capítulo 2 , e no trecho ampliado da mesma planta abaixo:

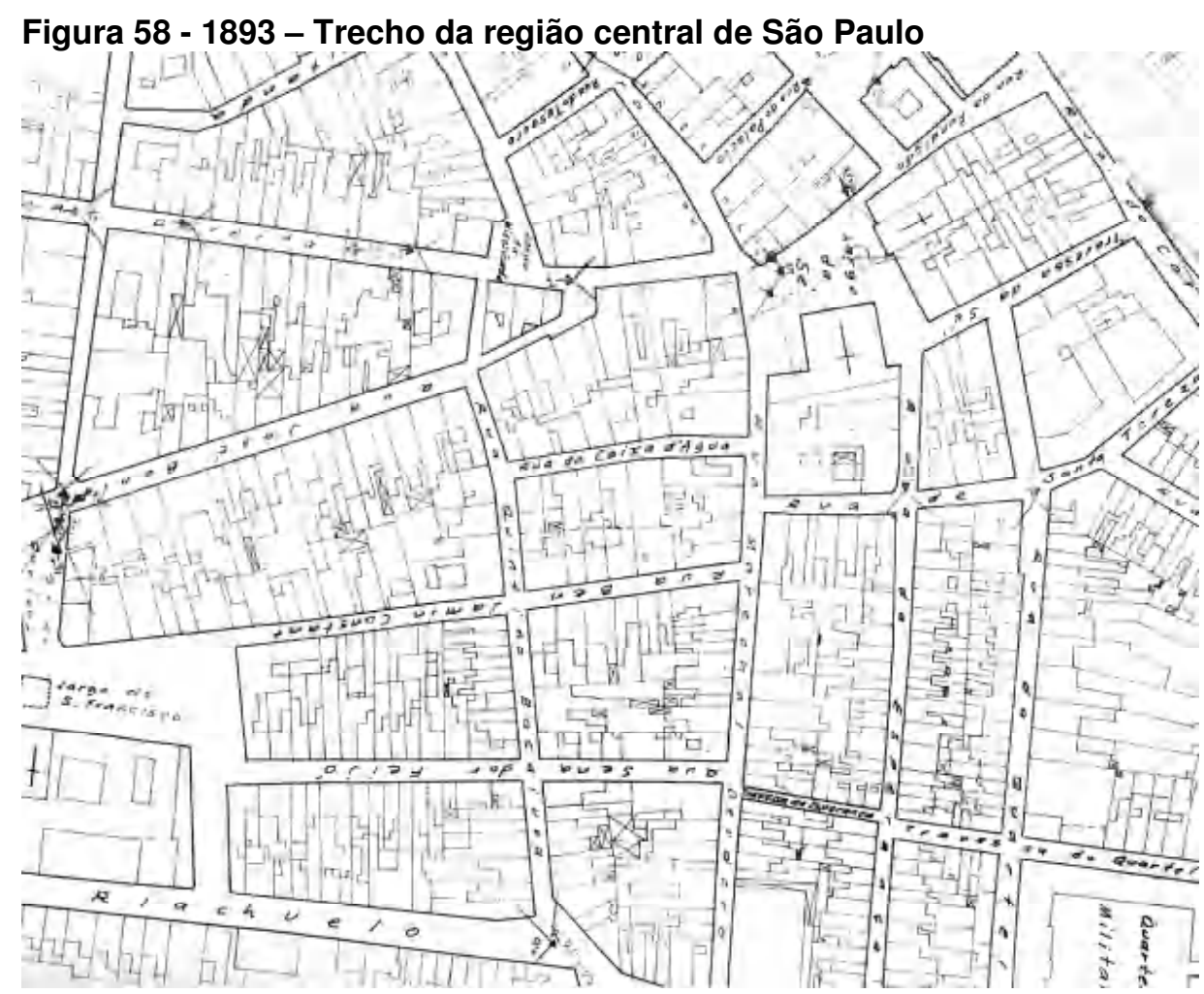

Planta da área central da cidade de São Paulo - levantada pelo engenheiro V. Huet de Bacellar em 1893. in: TOLEDO, Prestes Maia e as origens do urbanismo moderno em São Paulo. São Paulo, Empresa das Artes, 1996, p.68. 
A seguir, dando continuidade à exposição das leis urbanas paulistanas do século XX e complementando as interpretações gráficas das leis produzidas nesta pesquisa, serão expostos os conceitos legais presentes no código de obras de 1975, interpretados graficamente pela Secretaria da Habitação e Desenvolvimento Urbano do Município de São Paulo, por sua Assessoria de Legislação e Normalização Técnica.

Figura 59 - Lei no 8.266 de 1975 - Código de Edificações Implantação

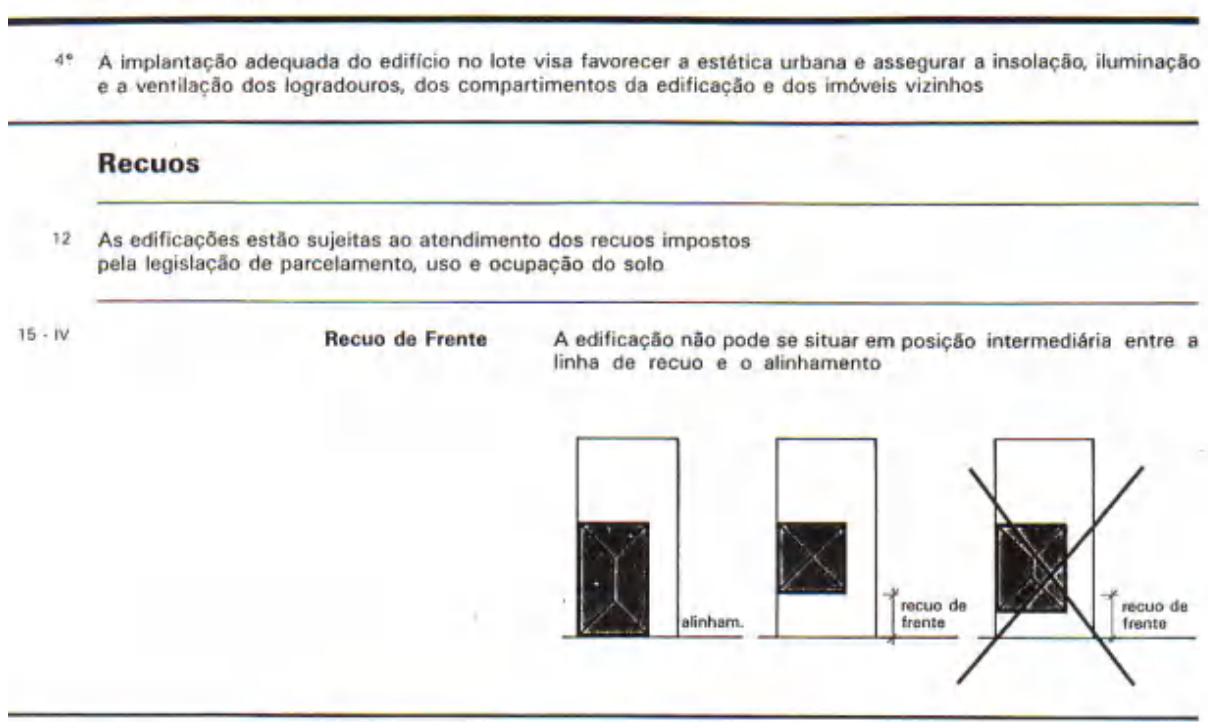

Edificações com Mais de 2 Andares ou com Até 2 Andares e H $>12,00$ m

Faixa Livre A1
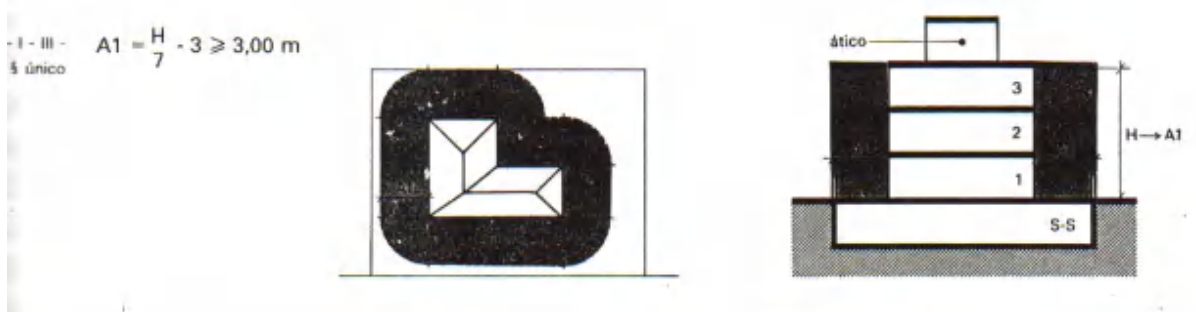

Súnico A1 aplica-se aos blocos sobrelevados de uma edificaçāo
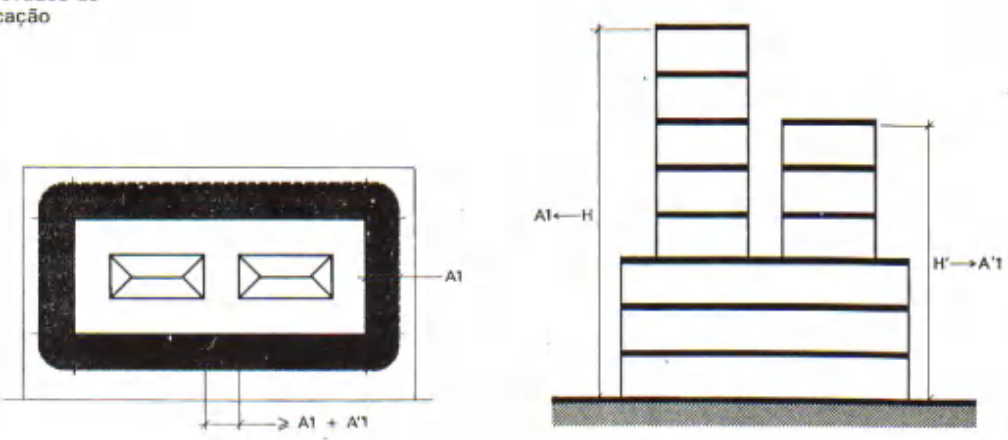

SEHAB, São Paulo/Edificações: Interpretação Gráfica: Código de Edificações / Secretaria da Habitação e Desenvolvimento Urbano, Assessoria de Legislação e Normalização Técnica. - 2 ed. São Paulo, PINI: Eternit, 1989. pág. 4. 
Figura 60 - Lei no 8.266 de 1975 - Código de Edificações

\section{Implantação}

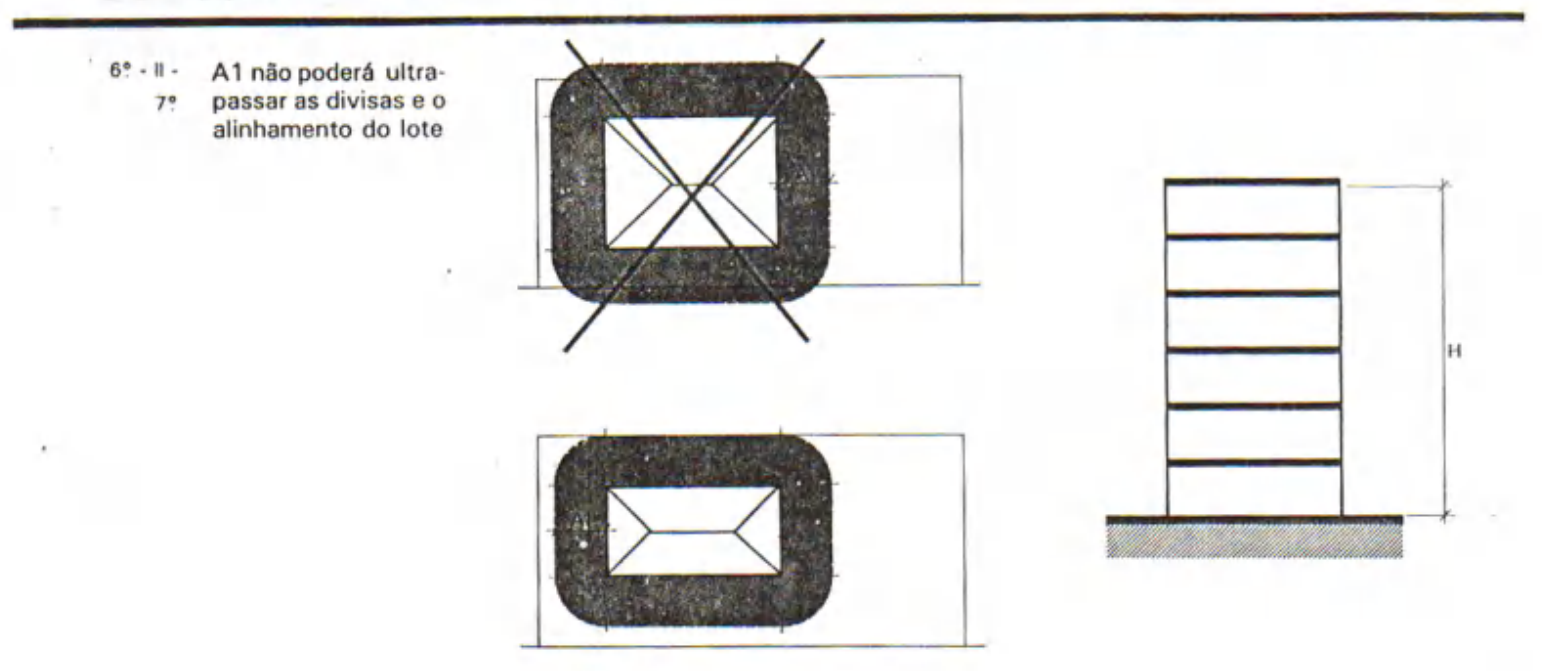

6! - II A1 não poderá interferir na faixa $A^{\prime} 1$ de outro edifício do mesmo imóvel
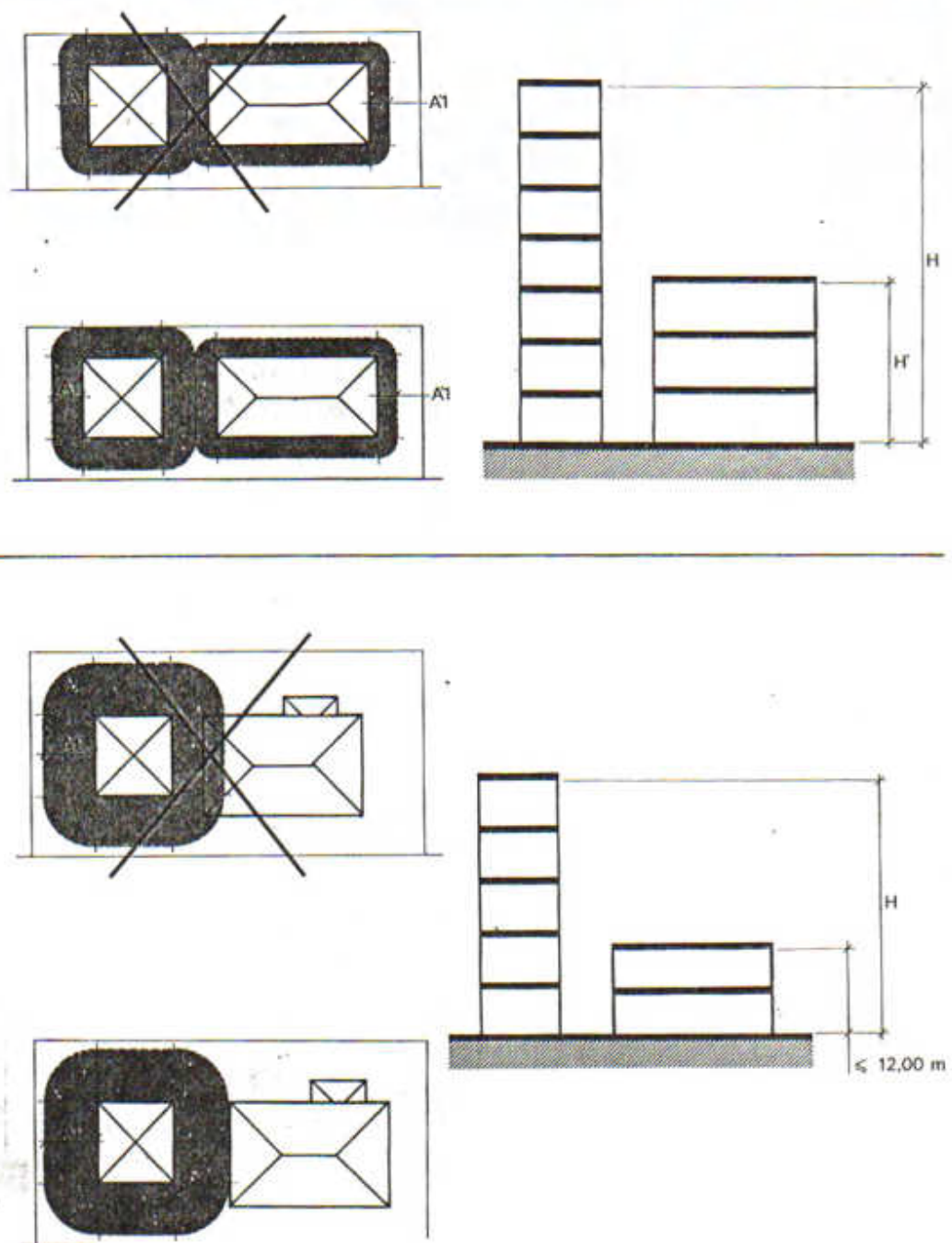

SEHAB, São Paulo/Edificações: Interpretação Gráfica: Código de Edificações / Secretaria da Habitação e Desenvolvimento Urbano, Assessoria de Legislação e Normalização Técnica. - 2 ed. São Paulo, PINI: Eternit, 1989. pág. 5. 
Figura 61 - Lei no 8.266 de 1975 - Código de Edificações

\section{Implantação}

$\begin{array}{rll}\text { ESOL.ICEUSOI } & \text { A1 não será exigido } & \begin{array}{l}\text { Os andares abaixo do pavimento térreo, as } \\ \text { partes sobrelevadas da edificaçăo, e as tor- } \\ \text { res que se apresentem nas condiçōes em que }\end{array} \\ 18 / 77 . " 3 " & \text { para } & \text { possam ser excluídos da altura H }\end{array}$

5 único - $a, b \quad$ Altura $H$
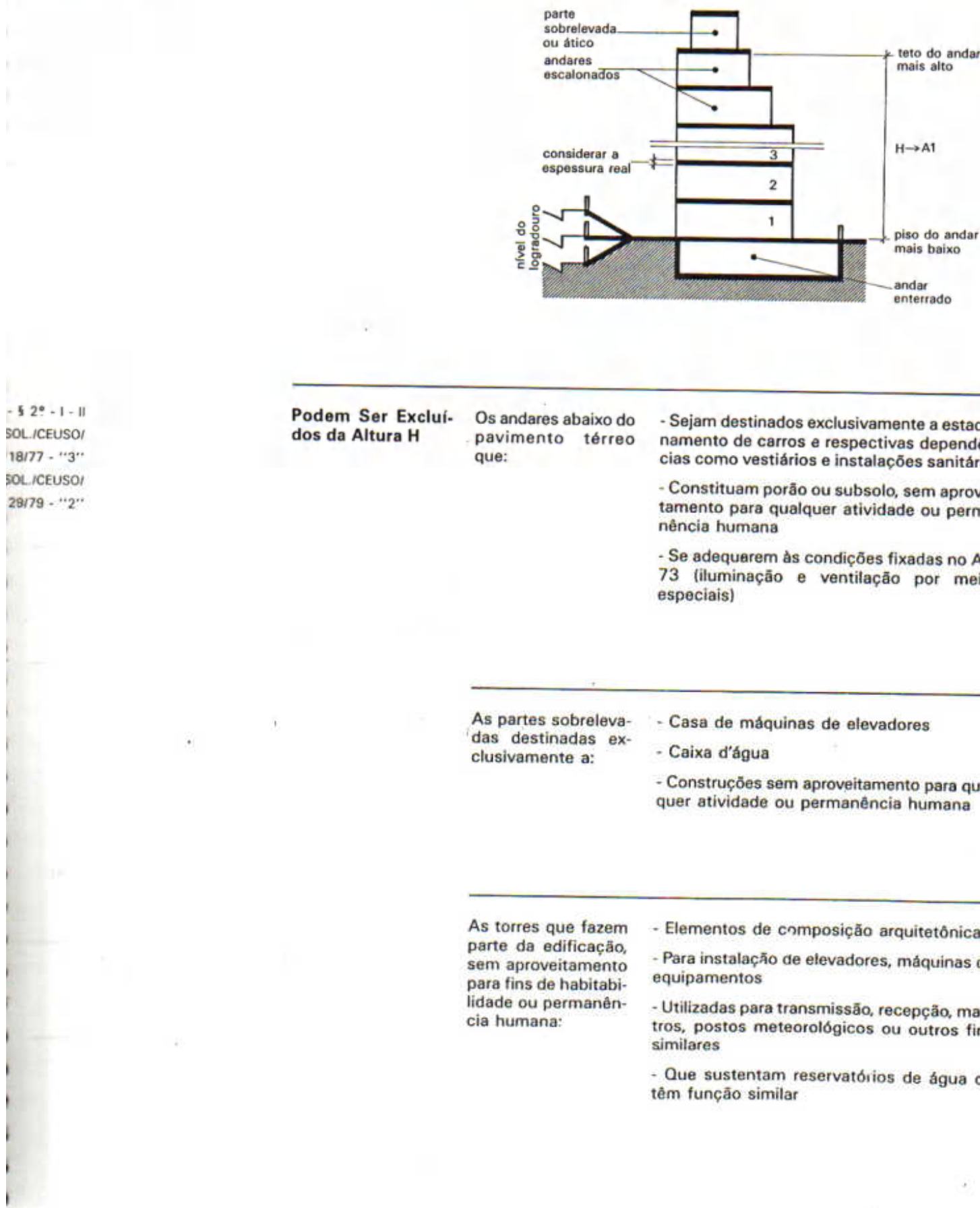

Podem Ser Excluídos da Altura $\mathrm{H}$
Os andares abaixo do pavimento térreo que:
- Sejam destinados exclusivamente a estacionamento de carros e respectivas dependências como vestiários e instalaçōes sanitárias

- Constituam porâo ou subsolo, sem aproveitamento para qualquer atividade ou permanência humana

- Se adequarem às condiç̋̄es fixadas no Art. 73 (iluminaçâo e ventilação por meios especiais)

SEHAB, São Paulo/Edificações: Interpretação Gráfica: Código de Edificações / Secretaria da Habitação e Desenvolvimento Urbano, Assessoria de Legislação e Normalização Técnica. - 2 ed. São Paulo, PINI: Eternit, 1989. pág. 6. 
Figura 62 - Lei no 8.266 de 1975 - Código de Edificações

\section{Implantação}

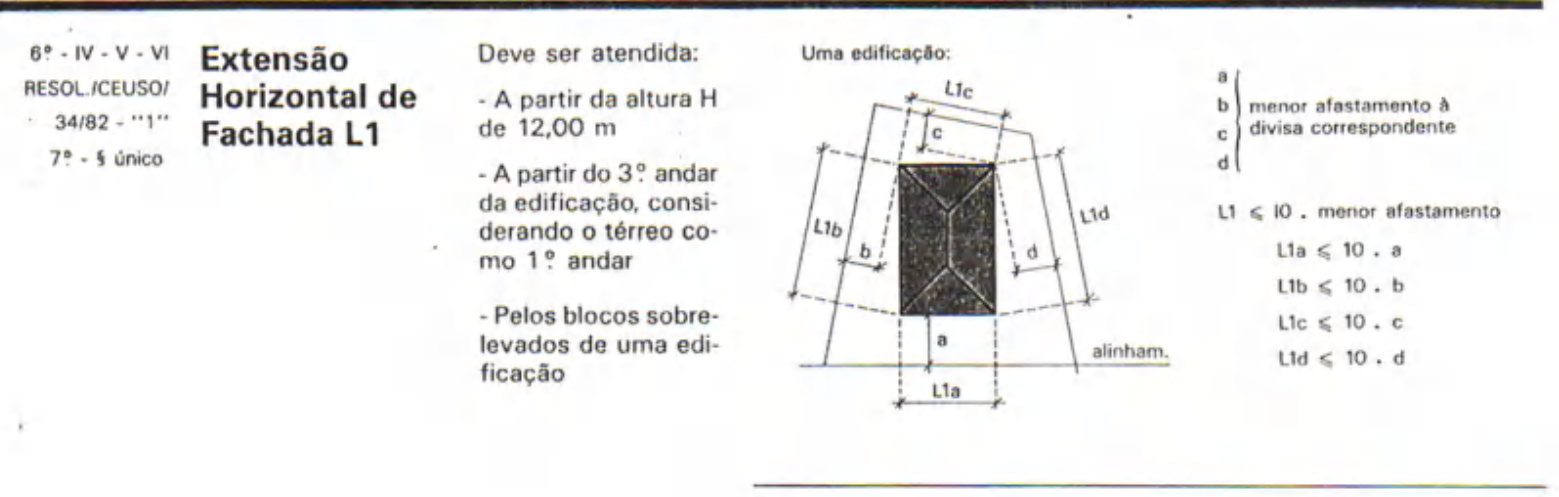

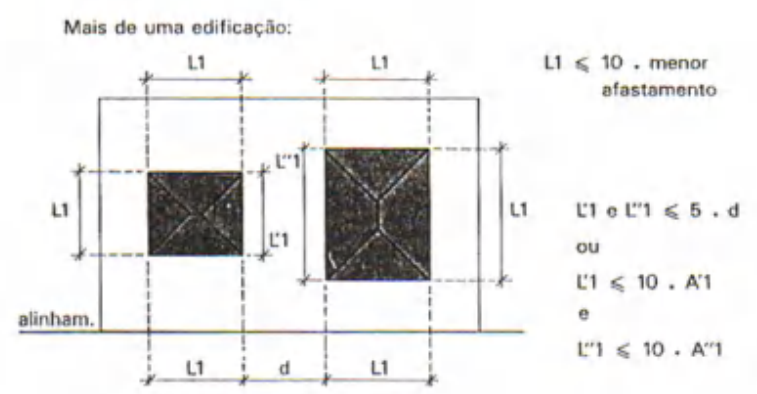

9:-a-s único Casos em que a Legislação de Parcelamento, Uso e Ocupação do Solo

RESOLICEUSOI

34/82 - "1" Admite

Edificações nos Alinhamentos ou nos Alinhamentos e nas Divisas do Lote

Altura $(\mathrm{H})$ dos 2 pri-

meiros andares

$\leqslant 12,00 \mathrm{~m}$

A1 e L1 começam a partir do 3 : andar, inclusive
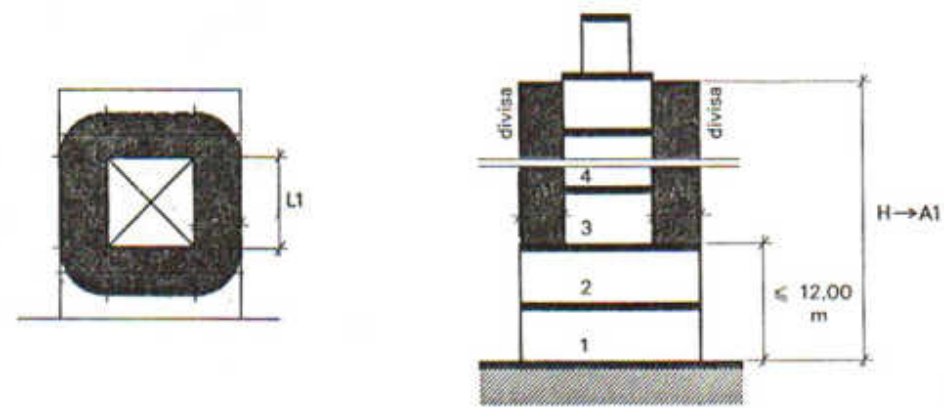

SEHAB, São Paulo/Edificações: Interpretação Gráfica: Código de Edificações / Secretaria da Habitação e Desenvolvimento Urbano, Assessoria de Legislação e Normalização Técnica. - 2 ed. São Paulo, PINI: Eternit, 1989. pág. 7. 
Figura 63 - Lei no 8.266 de 1975 - Código de Edificações

\section{Implantação}

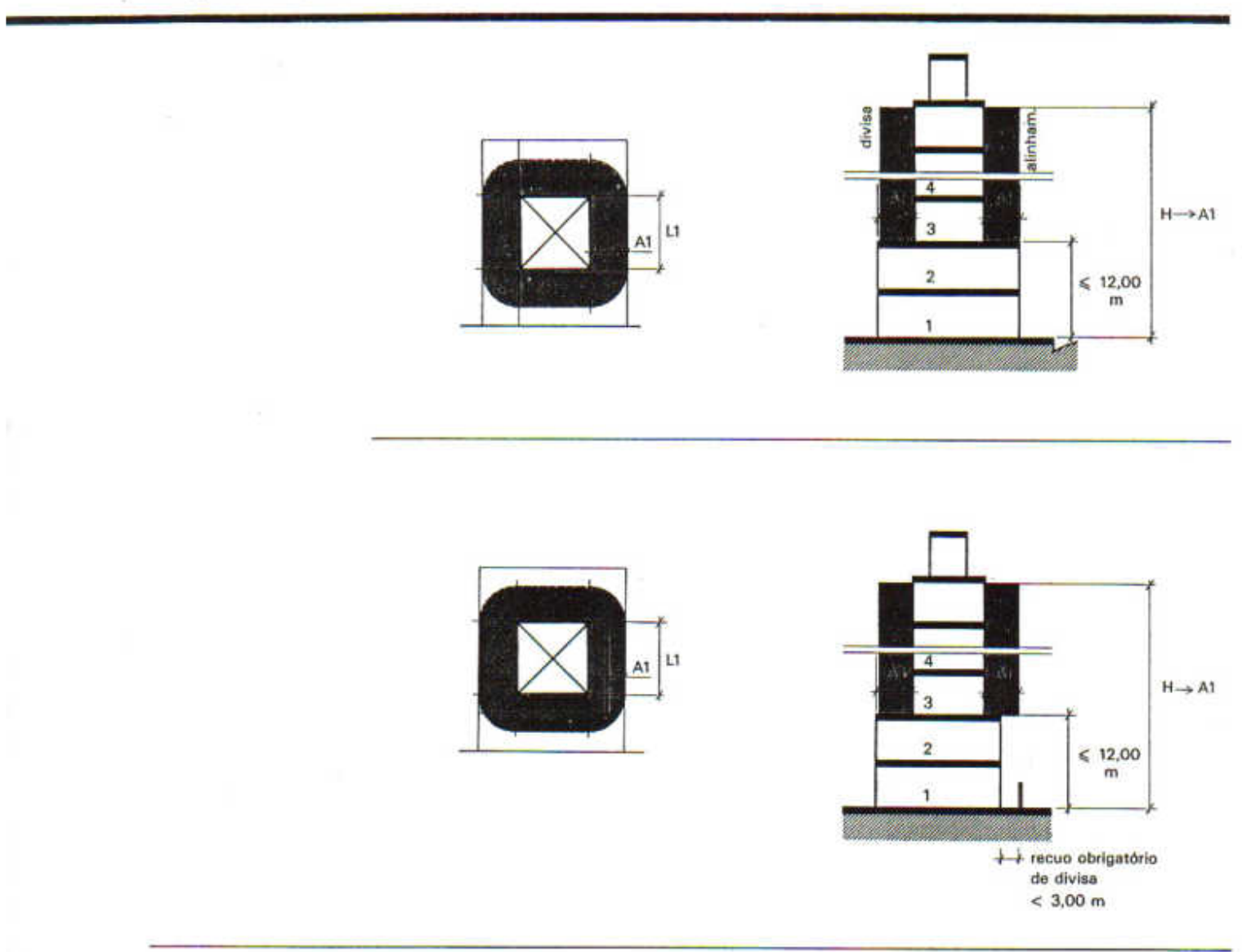

$9^{\circ} \cdot \mathrm{b}$ Altura $(\mathrm{H})$ dos 2 primeiros andares $>12,00 \mathrm{~m}$

A1 e L1 começam a partir da altura $(\mathrm{H})$ de $12,00 \mathrm{~m}$
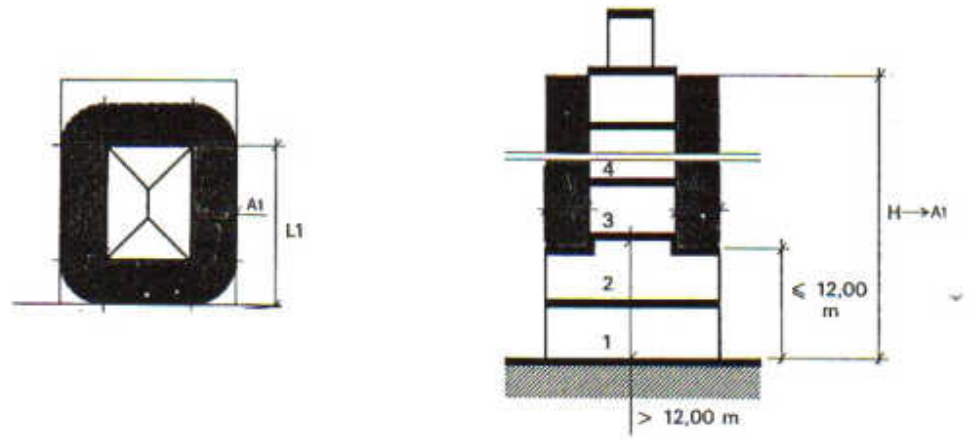

10. Edificações com até 2 Andares e $\mathbf{H} \leqslant 12,00$ m

Dispensadas da faixa $\mathrm{A} 1$ e da extensẫo L1

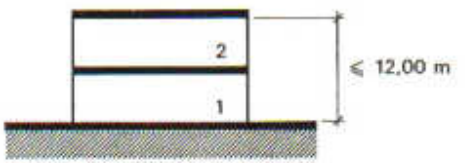

SEHAB, São Paulo/Edificações: Interpretação Gráfica: Código de Edificações / Secretaria da Habitação e Desenvolvimento Urbano, Assessoria de Legislação e Normalização Técnica. - 2 ed. São Paulo, PINI: Eternit, 1989. pág. 8. 
Figura 64 - Lei no 8.266 de 1975 - Código de Edificações

\section{Implantação}

Art. $2^{\circ}$ - 11 - Edificações nas Zonas de Uso Z5.001 e Z5.002

LEI $8844 / 78$

Dispensadas da faixa $\mathrm{A} 1 \mathrm{e}$ da extensåo L1

11 Distância Mínima entre Edificações no Mesmo Lote

$d \geqslant 1,50 \mathrm{~m}$

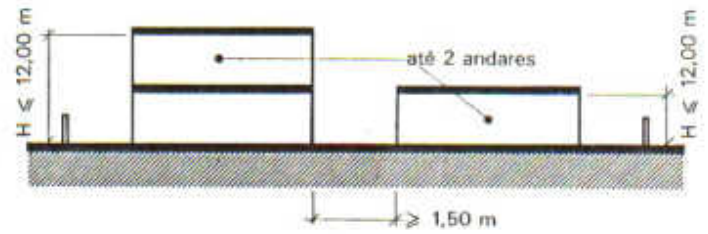

$d \geqslant 1,50 m$

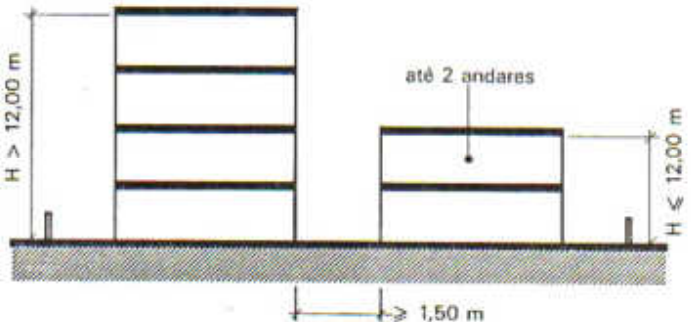

$d \geqslant A_{1}+A^{\prime} 1$

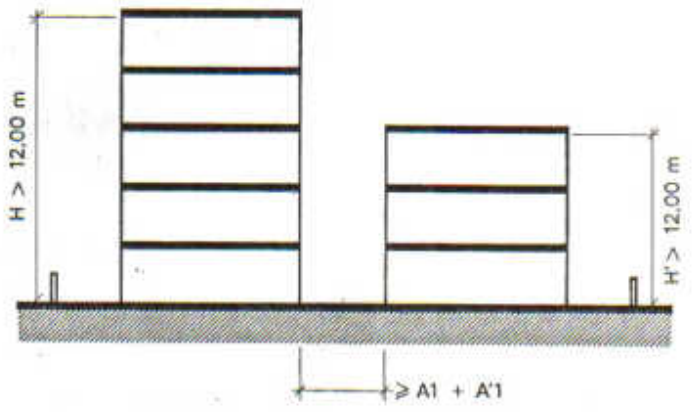

VER: "Insolaçāo, lluminação e Ventilação dos Compartimentos" - faixa livre ampliada A2

SEHAB, São Paulo/Edificações: Interpretação Gráfica: Código de Edificações / Secretaria da Habitação e Desenvolvimento Urbano, Assessoria de Legislação e Normalização Técnica. - 2 ed. São Paulo, PINI: Eternit, 1989. pág. 9. 
Figura 65 - Lei no 8.266 de 1975 - Código de Edificações

\section{Insolação, lluminação e Ventilação dos Compartimentos}

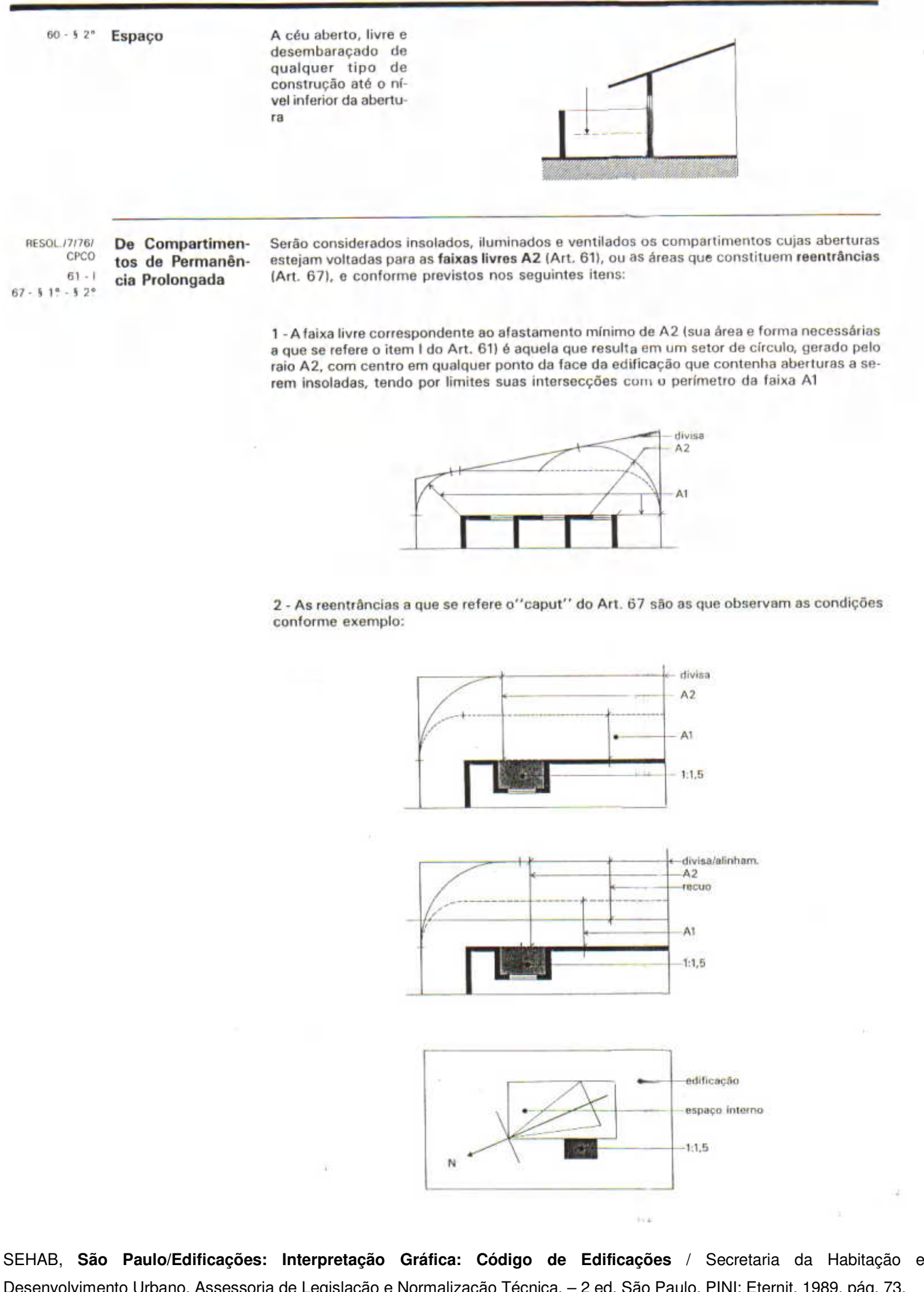

Desenvolvimento Urbano, Assessoria de Legislação e Normalização Técnica. - 2 ed. São Paulo, PINI: Eternit, 1989. pág. 73. 
Figura 66 - Lei no 8.266 de 1975 - Código de Edificações

Insolação, lluminação e Ventilação dos Compartimentos

3- As reentrâncias da edificação a que se refere o parágrafo 1 : do Art. 67 terão largura mínima igual a $\mathrm{A} 1+\mathrm{A} 2$, face ao que dispōe o item II do Art. 61

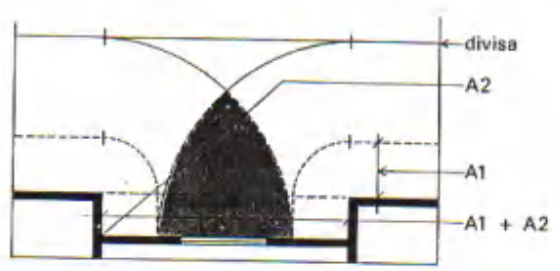

4 - A condição estabelecida no parágrafo 2 : do Art. 67 estará satisfeita quando o rebatimento de $\mathrm{A} 1$, no ponto de intersecção de sua respectiva faixa com a de $\mathrm{A} 2$ atingir o centro da abertura a ser insolada

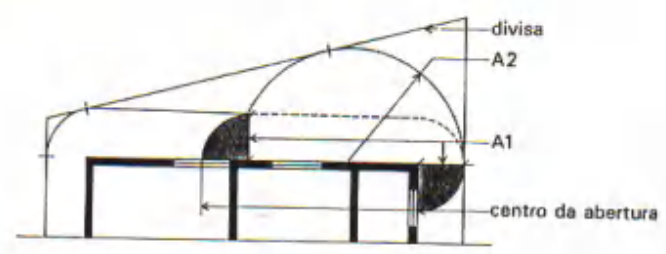

4.1 - Estará identicamente satisteita quando o rebatimento de $\mathrm{A} 1$, no ponto de intersecção da sua respectiva faixa com a de A2, mais o seu complemento até a divisa do terreno, atin. gir o centro de abertura a ser insolada, obedecendo a relaçăo de 1 para 1,5 prevista no item
desta norma

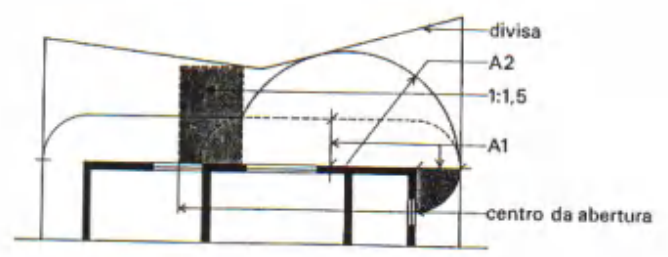

5 - Os projetos submetidos à aprovação deverão conter:

a - Cálculo das dimensões de A1 e A2 referentes às respectivas faixas livres b - Demonstração gráfica de que as referidas faixas livres (de A1 e A2) se inscrevam no, metro do terreno

$\begin{array}{ll}\text { Os compartimentos } & \text { Desde que: } \\ \text { poderão apresentar } & \\ \text { condiçōes adequa- } & \text { - Sejam integrantes de conjunto que justifi- } \\ \text { das de iluminaçắ e } & \text { que o tratamento excepcional } \\ \text { ventilação por meios } & \\ \text { especiais e, se for o } & \text { - Tenham asseguradas condiçōes de higiene, } \\ \text { caso, de controle de } & \text { conforto e salubridade acima do padrăo } \\ \text { temperatura e de } & \text { normal } \\ \text { grau de umidade do } & \\ \text { ar } & \begin{array}{l}\text { - Sejam observadas as normas técnicas } \\ \text { oficiais }\end{array}\end{array}$

SEHAB, São Paulo/Edificações: Interpretação Gráfica: Código de Edificações / Secretaria da Habitação e Desenvolvimento Urbano, Assessoria de Legislação e Normalização Técnica. - 2 ed. São Paulo, PINI: Eternit, 1989. pág. 74. 
Figura 67 - Lei no 8.266 de 1975 - Código de Edificações

Insolação, lluminação e Ventilação dos Compartimentos

RESOL ICEUSO/
31179 - "1, a"
AESOL./CEUSO $/$
$31179-" 1, \mathrm{~b} "$ ".
"2"

$61-1$

$61 \cdot 11$

61. II

$61-11$
Em edificaçōes nas zonas de uso Z5-001 e 25-002, para garantir a insolaçăo. iluminação e ventilação dos compartimentos
Săo permitidas aberturas voltadas para o logradouro, desde que:

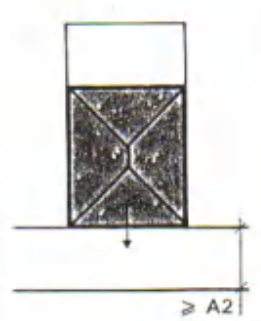

São permitidas aberturas voltadas para espaços internos (Art. 63 11), desde que:

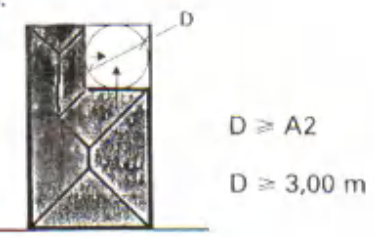

Observada a área minima para o espaço interno (Art. $63-11-$ a)
Faixa Livre Ampliada $A_{2}$
$A 2=\frac{H}{4} \cdot 3 \geqslant 3,00 m$

A2 năo poderá ultrapassar as divisas do lote

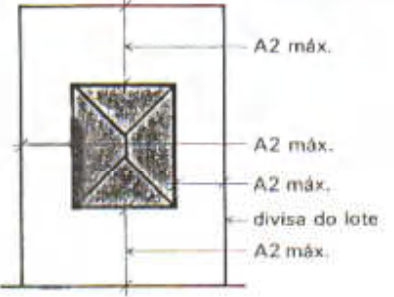

Em duas ou mais edificaçōes do mesmo imóvel A2 de uma náo poderá interferir em Al de outra

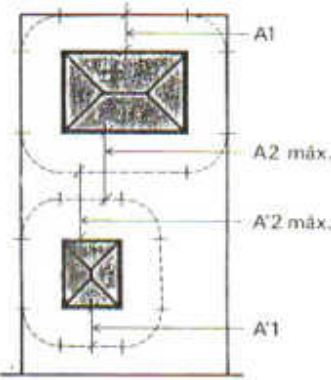

$$
\begin{aligned}
& \text { A2 poderá ser con- } \\
& \text { jugada com a faixa } \\
& \text { A2 da mesma ou de } \\
& \text { outra edificação do } \\
& \text { mesmo imóvel }
\end{aligned}
$$

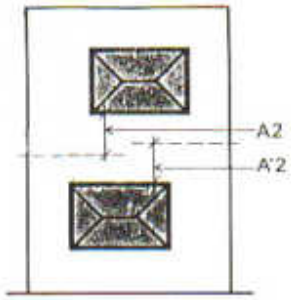

SEHAB, São Paulo/Edificações: Interpretação Gráfica: Código de Edificações / Secretaria da Habitação e Desenvolvimento Urbano, Assessoria de Legislação e Normalização Técnica. - 2 ed. São Paulo, PINI: Eternit, 1989. pág. 75. 
Figura 68 - Lei no 8.266 de 1975 - Código de Edificações

Insolação, lluminação e Ventilação dos Compartimentos

\begin{tabular}{|c|c|}
\hline \multirow[t]{3}{*}{ 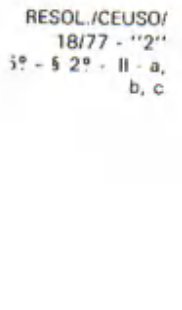 } & $\begin{array}{l}\text { A2 poderá se } \\
\text { lonado para } \\
\text { pos sobreleve }\end{array}$ \\
\hline & $A 2=\frac{H}{4}-3$ \\
\hline & $A^{\prime} 2=\frac{H^{\prime}}{4}$. \\
\hline
\end{tabular}

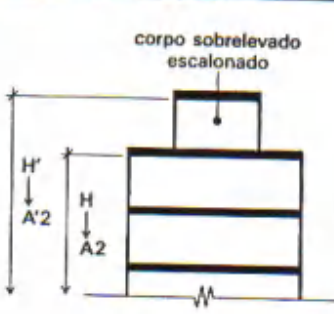

Desde que o corpo sobrelevado:

Tenha área $\leqslant 50 \%$ da área do pavimento tipo, excluídas as áreas que:

- Constituírem elemento de composição arquitetônica, como zimbórios, belvederes, minaretes, campanários ou torres de templos religiosos

- Servirem à instalação de elevadores, máquinas ou equipamentos

- Forem utilizados para transmissão, recepçâo, mastros, postos meteorológicos ou outros fins similares

- Formarem a sustentaçāo de reservatórios de água ou tiverem funçåo similar

Seja constituido por:

- Apartamento para zelador $\leqslant 60,00 \mathrm{~m}^{2}$

- Depósito para material de limpeza $\leqslant$ $4,00 \mathrm{~m}^{2}$

- Vestiários $\leqslant 4,00 \mathrm{~m}^{2}$

- Sanitários $\leqslant 2,40 \mathrm{~m}^{2}$

- Lazer ou salão de festas $\leqslant 30,00 \mathrm{~m}^{2}$

- Compartimentos que sejam dependência e. clusiva das unidades do andar imediatamen te inferior, tipo duplex, com comunicaçäo in terna obrigatória

Admitidos:

- Casa das máquinas do elevador

- Caixa d’água

- Outras construçōes sem aproveitamento pa. ra qualquer atividade ou permanência humana

A2 nåo será exigido para
Os andares abaixo do pavimento térreo, e as partes sobrelevadas da edificação que se apresentem nas condiçōes em que possam
ser excluidos da altura $H$

SEHAB, São Paulo/Edificações: Interpretação Gráfica: Código de Edificações / Secretaria da Habitação e Desenvolvimento Urbano, Assessoria de Legislação e Normalização Técnica. - 2 ed. São Paulo, PINI: Eternit, 1989. pág. 76. 
Figura 69 - Lei no 8.266 de 1975 - Código de Edificações

\section{Insolação, Iluminação e Ventilação dos Compartimentos}

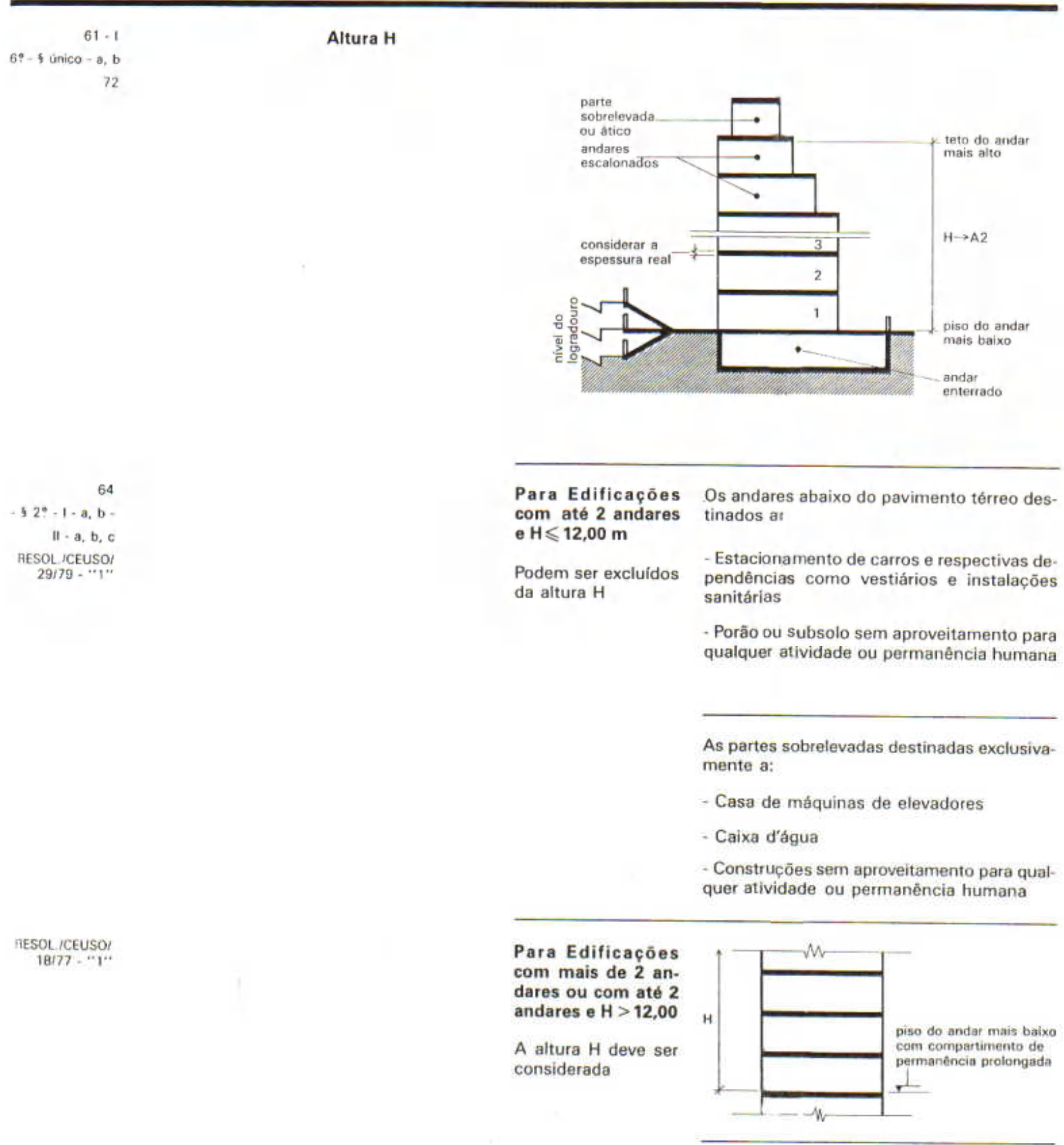

SEHAB, São Paulo/Edificações: Interpretação Gráfica: Código de Edificações / Secretaria da Habitação e Desenvolvimento Urbano, Assessoria de Legislação e Normalização Técnica. - 2 ed. São Paulo, PINI: Eternit, 1989. pág. 77. 
A Lei n 10.209, de 1986 estabeleceu as Operações Interligadas, que consistiram na permissão onerosa do não atendimento de características da legislação ou da aquisição de potencial construtivo (solo-criado) a mais do que o previsto em lei. $\mathrm{O}$ pagamento seria feito pela execução ou financiamento de determinado número de habitações de interesse social em valor equivalente à parte do benefício adquirido (GIAQUINTO, 1995, p.78). A Lei no 10.334 de 1987, Áreas Especiais de Tráfego, segunda alteração do zoneamento de 1972, pretendia adequar o uso do solo ao melhor desempenho do sistema viário. Um anos depois, a Constituição Federal de 1988, diversamente de todas as Constituições anteriores, ocupou-se dos direitos fundamentais com prioridade em relação às demais matérias. Criado neste ano, o Plano Diretor de São Paulo vigorou até a criação da Lei no 13.430/2002, sendo um plano integrado, de intenções e discursos, pretendendo alterar algumas questões do Zoneamento e prever formas de parceria entre os setores público e privado (Operações Urbanas e Interligadas). O seu texto, como o P.D.D.I. de 1971, foi escrito diretamente na forma de lei.

Figura 70 - Zoneamento na área em estudo: 1988

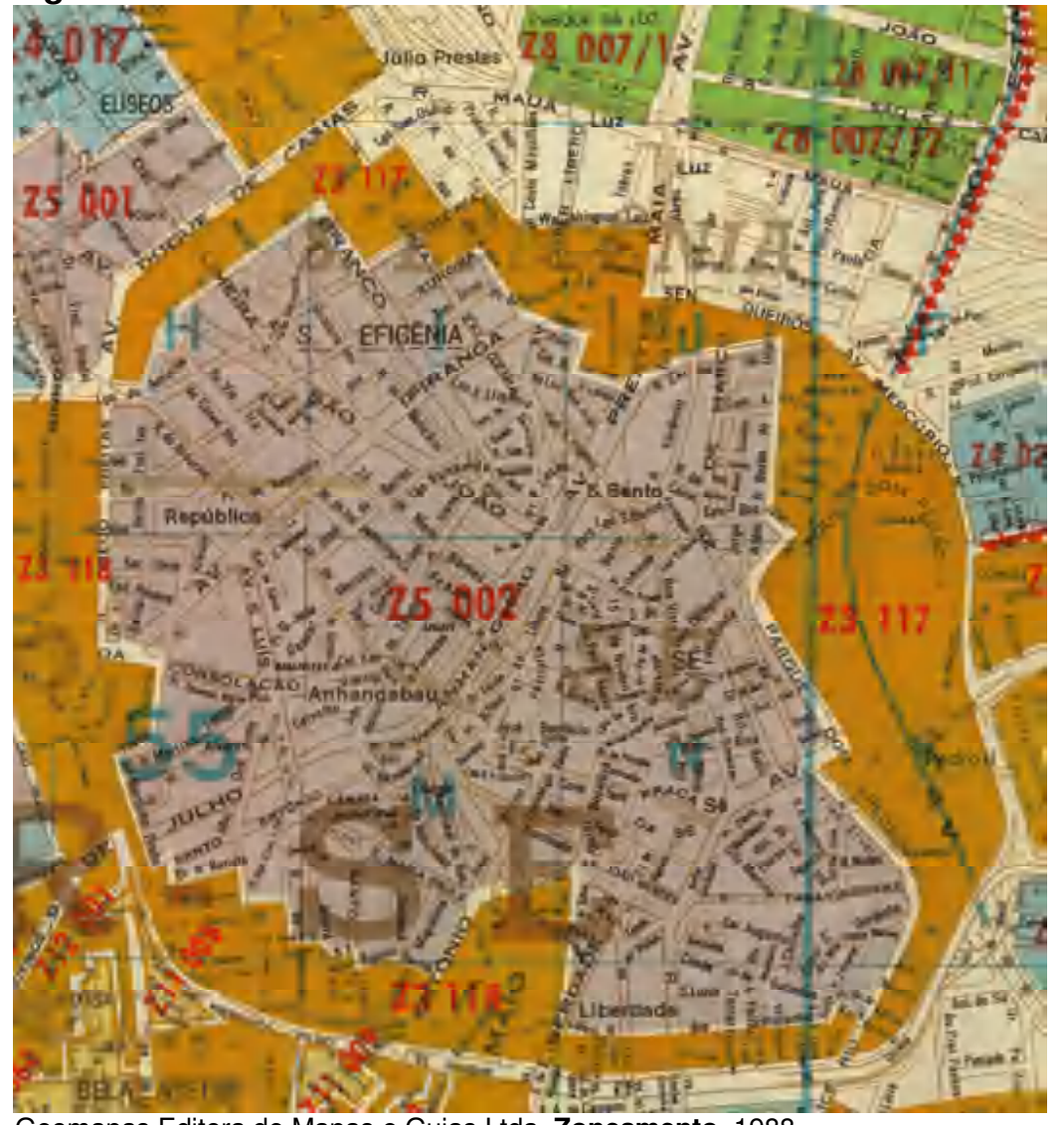

Geomapas Editora de Mapas e Guias Ltda. Zoneamento, 1988 
A Lei 11.090 de 1991, Operação Urbana Anhangabaú, instrumento jurídico de desregulamentação do modelo urbanístico da L.P.U.O.S. Como as Operações Interligadas, seria o financiamento de um plano de obras de melhorias no Vale do Anhangabaú com a receita da venda de potencial construtivo e outras características urbanísticas para empreendimentos imobiliários neste perímetro. O controle do adensamento foi feito por um estoque de potencial construtivo de $150.000 \mathrm{~m} 2$, considerado compatível com a infra-estrutura, equipamentos e serviços públicos existentes. Esta lei foi extinta três anos após sua criação, conforme previsto no próprio corpo da lei.

A lei 11.228 de 1992, o Novo Código de Obras e Edificações, foi promulgada com o objetivo de ser compreendido por toda a comunidade de técnicos e, desta vez, separando completamente as questões construtivas (edilícias) das questões de zoneamento (urbanísticas). De acordo com GIAQUINTO (1995) durante a partir de 1972 com a criação das leis urbanísticas e edilícias, que inclusive se sobrepuseram em determinados períodos, havia certa manipulação do conhecimento por parte dos técnicos em função da complexidade da legislação.

Figura 71 - Lei no 11.228 de 1992 - Novo Código de Obras e Edificações

DESENHO 10-III.a

CLASSIFICAÇĀO DOS VOLUMES

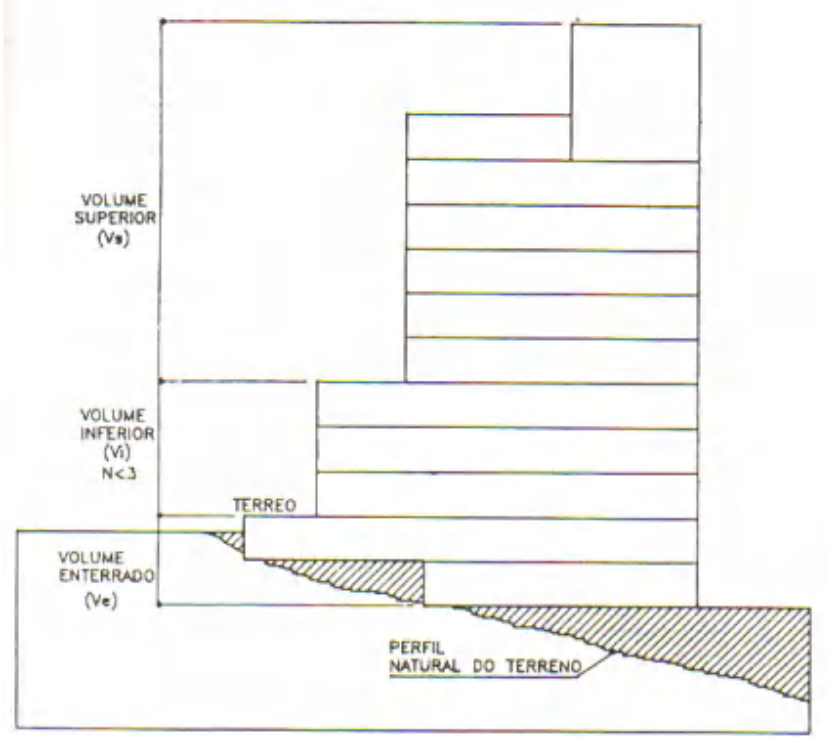

BLOCH, Luiz Laurent e BOTELHO, Manuel Henrique Campos. Código de Obras e Edificações do Município de São Paulo Comentado e Criticado. São Paulo, Pini, 1993. pág. 229. 
Figura 72 - Lei nº 11.228 de 1992 - Novo Código de Obras e Edificações

DESENHO 10-V.o

FAIXA LIVRE "A"

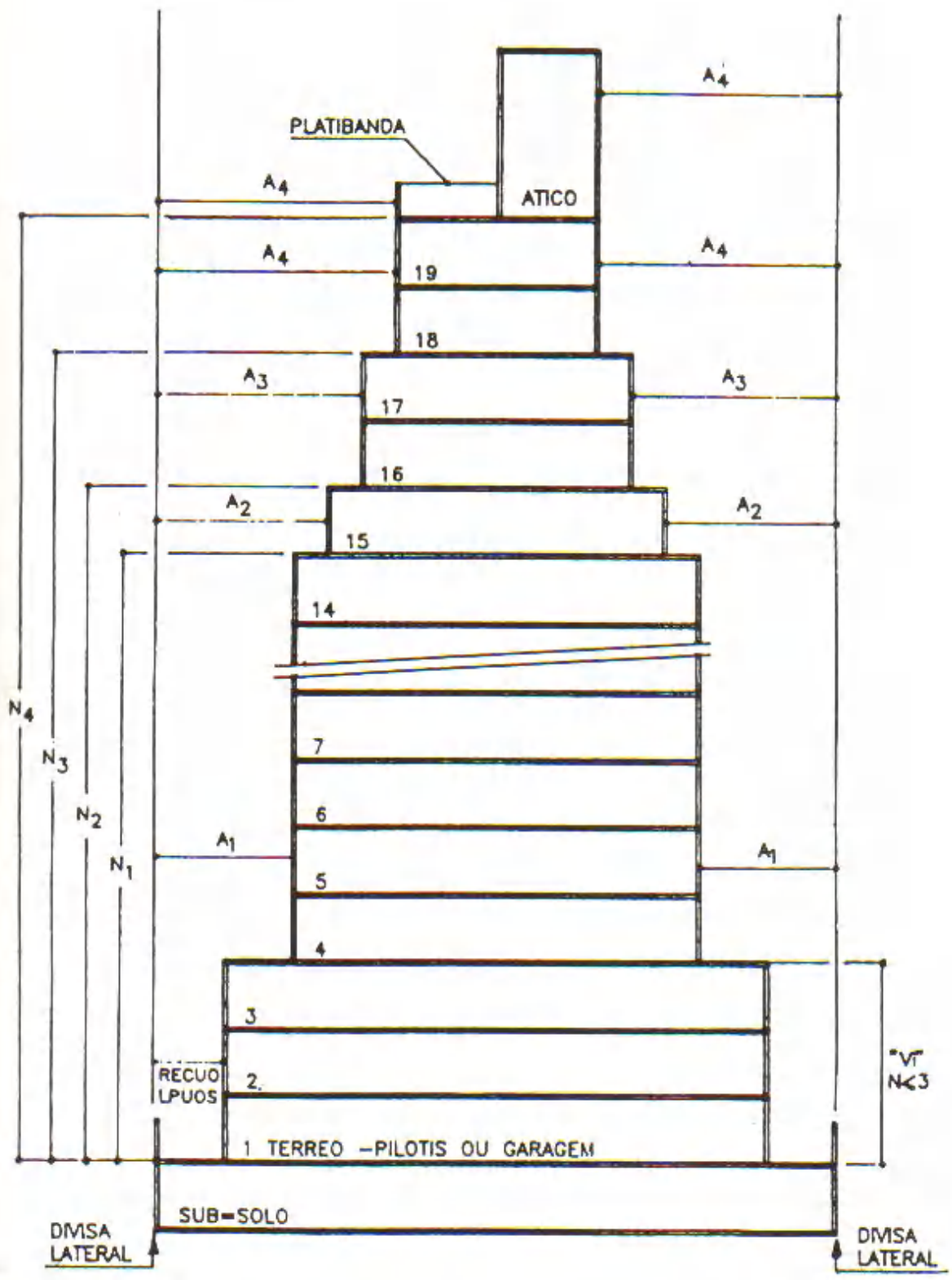

Desenho 10.V.a Faixa livre "A"

$O$ desenho mostra que com o crescer do prédio văo surgindo várias faixas " $A$ ". O escalonamento dos andares propicia que mesmo com ocrescer dos andares não aumente o valor da faixa livre que derermina o recuo para aeraçăo. (ver pág. 187)

BLOCH, Luiz Laurent e BOTELHO, Manuel Henrique Campos. Código de Obras e Edificações do Município de São Paulo Comentado e Criticado. São Paulo, Pini, 1993. pág. 233. 
Figura 73 - Lei no 11.228 de 1992 - Novo Código de Obras e Edificações

DESENHO 10-V.b

FAIXA LIVRE "A"
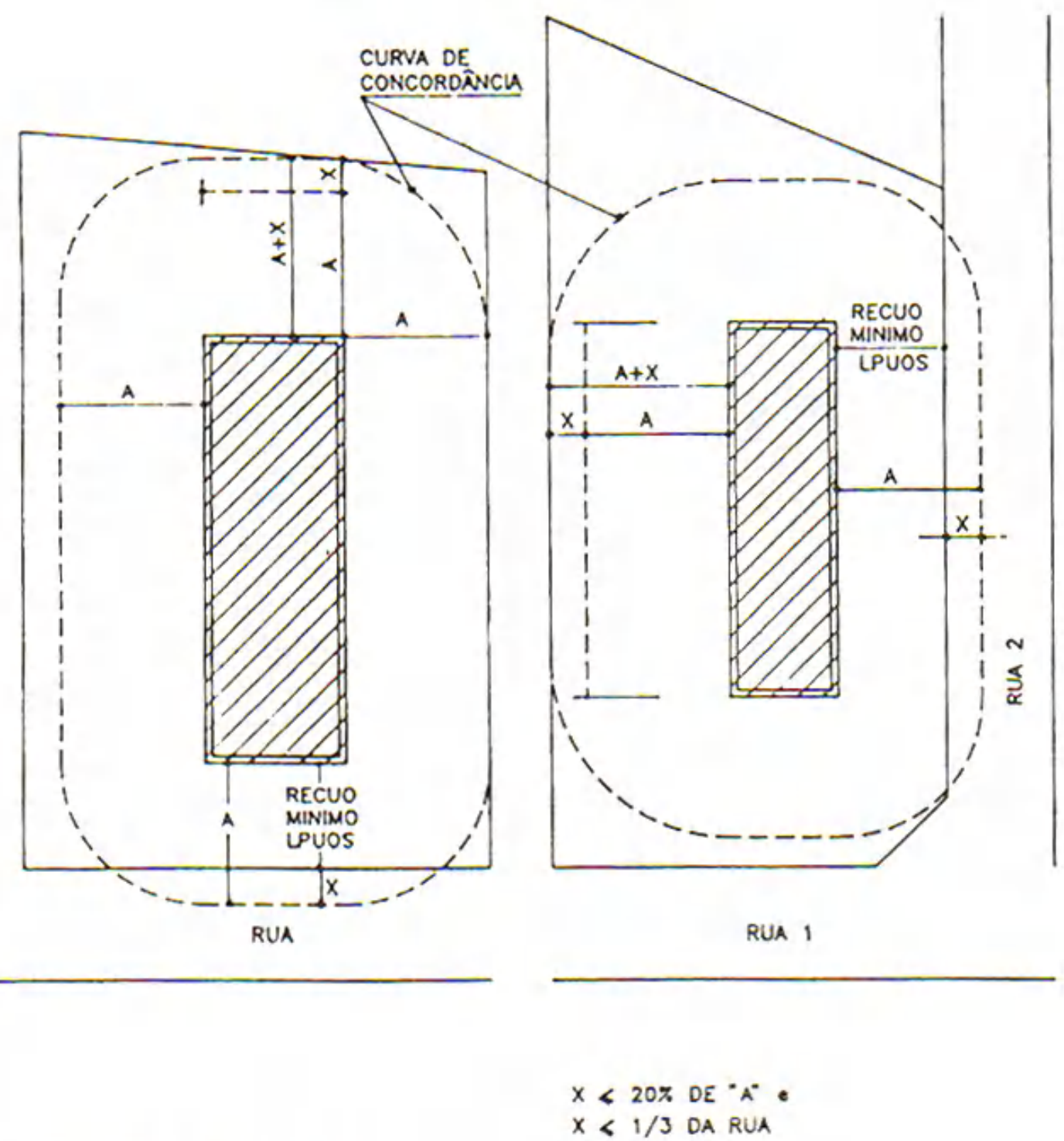

Desenho 10.V.b Faixa live "A"

Odesenho mostra claramenre a possibilidade da faixa "A" ccupar parte de logradouro público mas fazendo uma compensaço nos fundos Ocorre uma trans. laço das haixas

BLOCH, Luiz Laurent e BOTELHO, Manuel Henrique Campos. Código de Obras e Edificações do Município de São Paulo Comentado e Criticado. São Paulo, Pini, 1993. pág. 234. 
Figura 74 - Lei nº 11.228 de 1992 - Novo Código de Obras e Edificações

DESENHO 10-V.a

FAIXA LIVRE "I"

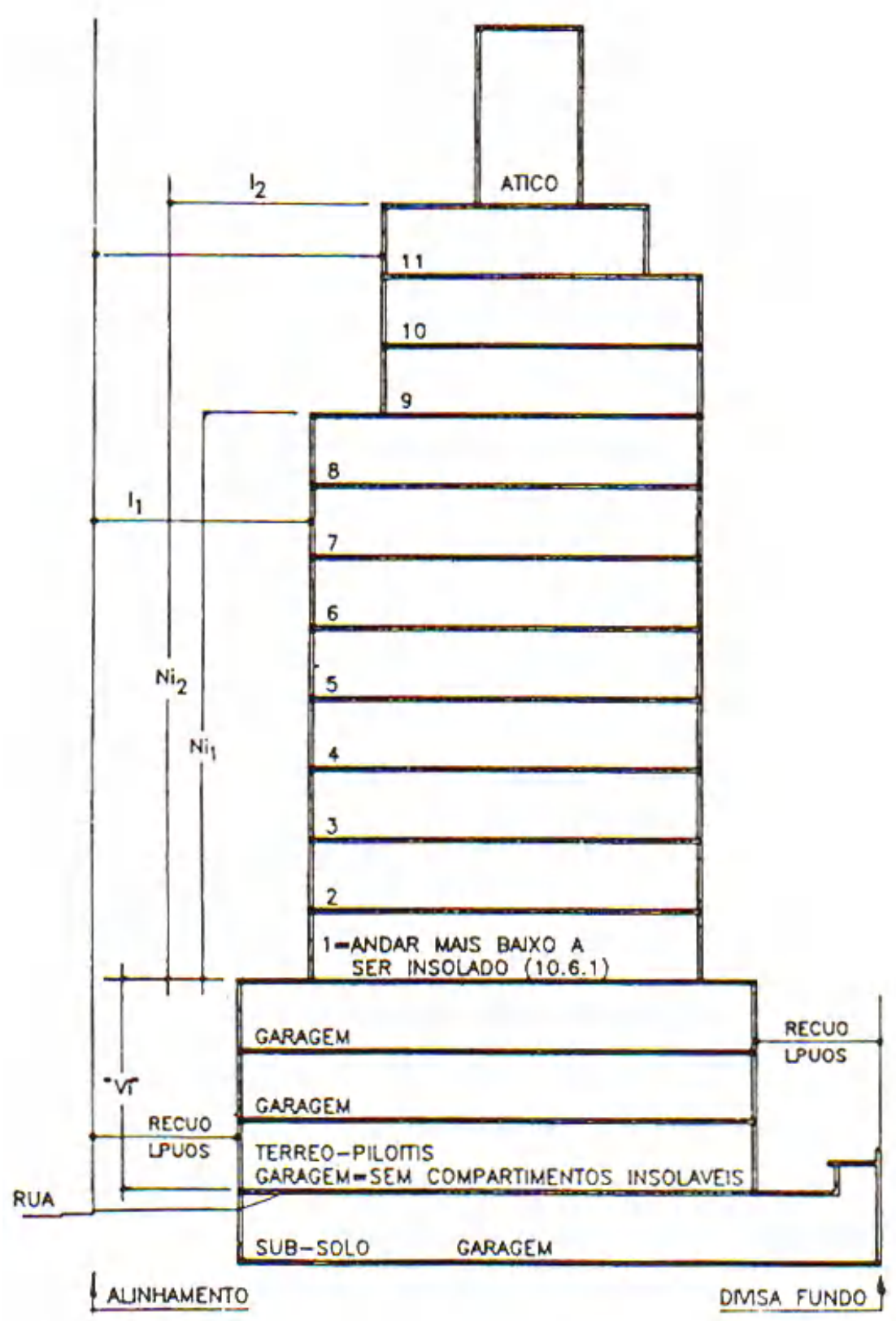

Desenho 10-VI.a Faixa livre " $I$ "

O termo da lej é "espaço livre" e não "faixa livre".

$O$ desenho mostra o crescimento do 'espaço livre

' em função do aumento do número de andares.

Norar que só existe exigência de faixa livre para o

volume Vs.

BLOCH, Luiz Laurent e BOTELHO, Manuel Henrique Campos. Código de Obras e Edificações do Município de São Paulo Comentado e Criticado. São Paulo, Pini, 1993. pág. 235. 
Figura 75 - Lei nº 11.228 de 1992 - Novo Código de Obras e Edificações

DESENHO 10-V.b

ESPACO LIVRE "I"

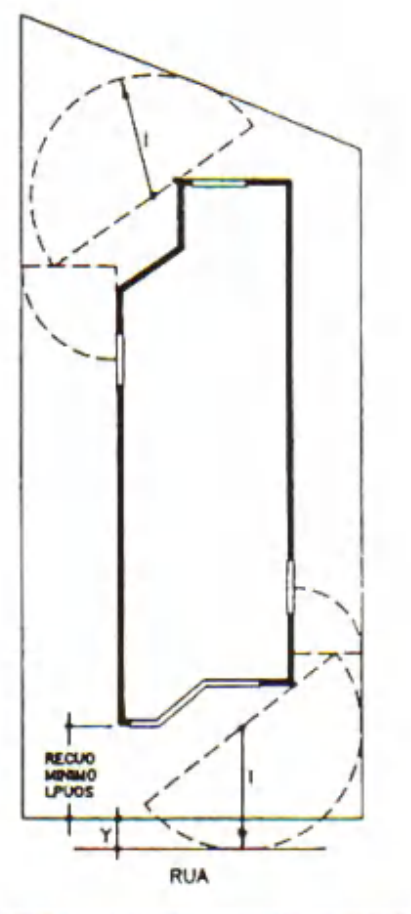

$4<20 \pi, 10$

$Y \leqslant 1 / 3$ DA RUA oеsento 10-mb

ESPACO UVRE " $\mathrm{C}$

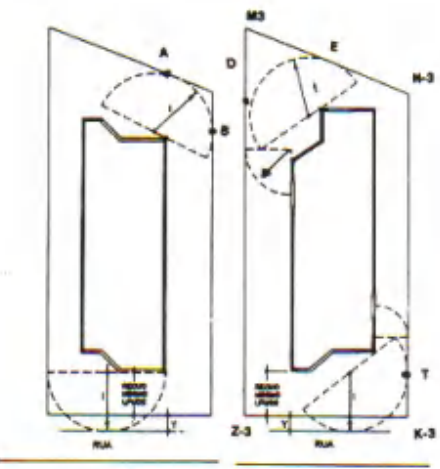

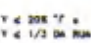

No desenho à esquerda nio há erros de grafismos, mas para êniase mostramos os ponros de tangência $A$ e B. No desenho da direita o trecho de reta $M$-3 Z-3 deveria tangenciar o semicirculo (superior) de raio I numponto que denominamos D. Ao tangenciat no ponto $D$ fica definido o raio do quarto de circulo existente à esquerda do desenho No semicirculo inferior nảo aconteceu o erro de grafismo. $O$ ponto de tangencia que denominamos $T$ vai gerar o raio do quarto de circulo existente nesse lado do desenho.
Desenho 10-VT.b Espaço Live "T"

$O$ desenho explicica o texto do Anexo I itens 10.6 .1 e 10.6 .11 da lei. Náo está claro o que é, e para o que é o quarto de circulo do desenho da direita E mostrada a passibilidade do espaço livre "I" ocupar parte da rua

BLOCH, Luiz Laurent e BOTELHO, Manuel Henrique Campos. Código de Obras e Edificações do Município de São Paulo Comentado e Criticado. São Paulo, Pini, 1993. pág. 236. 
Figura 76 - Lei no 11.228 de 1992 - Novo Código de Obras e Edificações

DESENHO 10-VI.c

ESPACO LIVRE. "I"

FAIXA LIVRE "A"

REBATIMENTOS

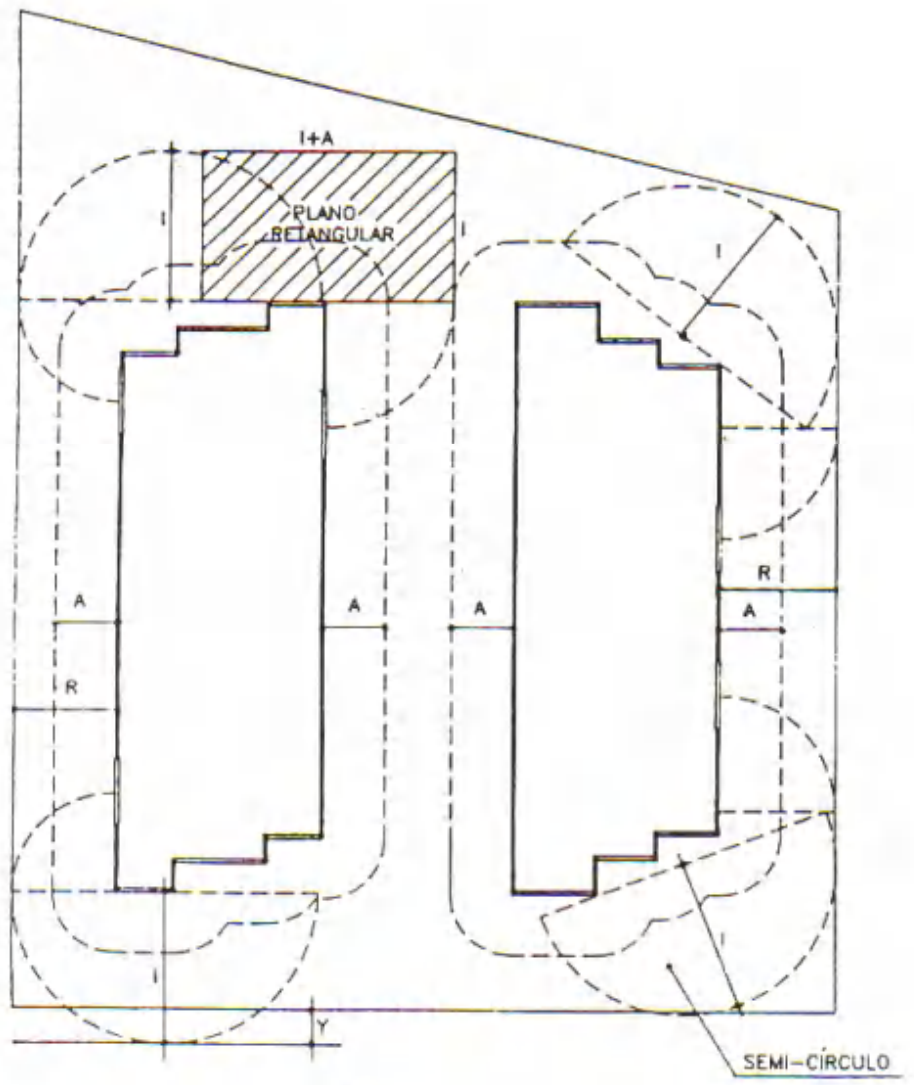

RUA

BLOCH, Luiz Laurent e BOTELHO, Manuel Henrique Campos. Código de Obras e Edificações do Município de São Paulo Comentado e Criticado. São Paulo, Pini, 1993. pág. 237.
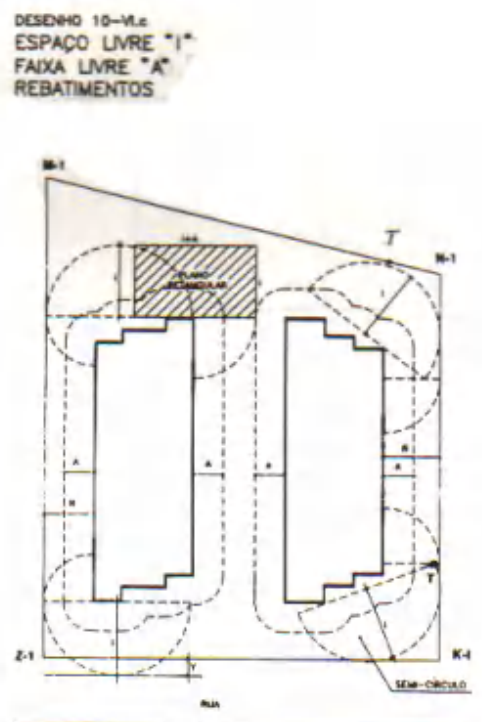

Otrecho de reta M.1 N.1 (parte superior do desenho) deveria rangenciar o semicirculo de raio I num ponto que denominamos $\mathrm{T} \mathrm{Hi}$, pois, um erro de grafismo no desentho $O$ raio $R$ do quarto de circulo menor resulta da tangência do trecho de reta N.I K.I. No lado esquerdo do desenho, o trecho de reva M.I Z.1 tangencia o semicírculo de raio / e com isso fica definido o valor $R$ que e o raio do quarto de cículo mostrado na parte superior c inferior do dese. nho

Desenho 10-V.c Espaco livre "T" Faika Itvre "A" Rebatimentos

É mastrado o retangulo que pode substituir o semi. círculo no projeto da edificaço. Nesse desenho, o raio do quarto de circulo é denominado $R$ e que os autores entendem que seja o recuo fixado pela LPUOS 
Figura 77 - Zoneamento na área em estudo: 1994

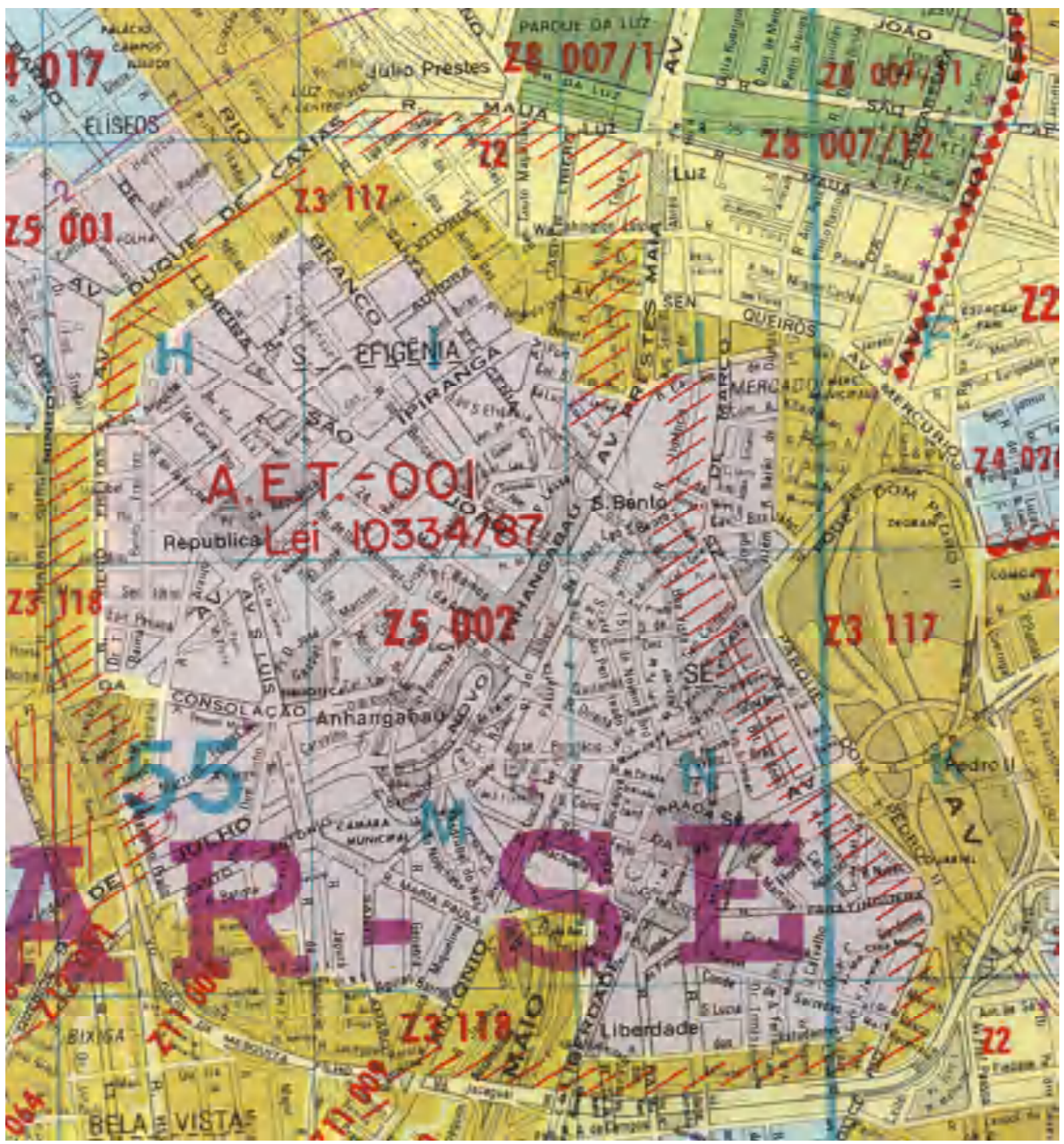

FONTE: Geomapas Editora de Mapas e Guias Ltda. Zoneamento, 1994

A Lei no 12.349 de 1997 - As diretrizes urbanísticas da Operação Urbana Centro são: 1- A abertura de praças e de passagens para pedestres no interior das quadras; Permissão de aumento do coeficiente de aproveitamento como estímulo ao remembramento de lotes e à interligação de quadras mediante o uso dos espaços aéreo e subterrâneo dos logradouros públicos; 2- A disciplina do espaço destinado ao transporte individual e a adequação dos espaços destinados ao transporte 
coletivo; 3- O incentivo à não impermeabilização do solo e à arborização das áreas não ocupadas; 4- A conservação e restauro dos edifícios de interesse histórico, arquitetônico e ambiental, mediante instrumentos apropriados; 5- A composição das faces das quadras, de modo a valorizar os imóveis de interesse arquitetônico e a promover a harmonização do desenho urbano; 6- A adequação, aos objetivos desta lei, do mobiliário urbano existente e proposto; 7 - $O$ incentivo à construção de habitações; 8- $O$ incentivo à construção de garagens; 9 - $O$ incentivo à recuperação e reciclagem de prédios públicos existentes na área central; 10- A criação de condições para a implantação de ruas ou regiões comerciais com regime de funcionamento de 24 (vinte e quatro) horas por dia; 11- $O$ desestímulo à permanência e a proibição de instalação de novos estabelecimentos de comércio atacadista de cereais, de madeiras e de frutas na área da Operação Urbana.

Sendo os objetivos específicos desta lei: a- Implementar obras de melhoria urbana na área delimitada pelo perímetro da Operação Urbana Centro; b- Melhorar, na área objeto da Operação Urbana Centro, a qualidade de vida de seus atuais e futuros moradores e usuários permanentes, promovendo a valorização da paisagem urbana e a melhoria da infra-estrutura e da sua qualidade ambiental; c- Incentivar o aproveitamento adequado dos imóveis, considerada a infra-estrutura instalada; $d$ Incentivar a preservação do patrimônio histórico, cultural e ambiental urbano; eAmpliar e articular os espaços de uso público; f- Iniciar um processo de melhoria das condições urbanas e da qualidade de vida da área central da cidade, especialmente dos moradores de habitações subnormais; g- Reforçar a diversificação de usos na área central da cidade, incentivando o uso habitacional e atividades culturais e de lazer; $\mathrm{h}$ - Melhorar as condições de acessibilidade à área central da cidade; iIncentivar a vitalidade cultural e a animação da área central da cidade; j- Incentivar a localização de órgãos da administração pública dos três níveis de governo na área central da cidade. 


\section{5- MAPEAMENTO DAS LEIS}

Neste capítulo, busca-se validar a interpretação gráfica da legislação presente no capítulo anterior. Sendo assim, serão expostas imagens de vias do "centro" de São Paulo, que no período de estudo desta pesquisa foram caracterizadas pelas restrições e exigências legais específicas para edifícios em lotes particulares. Expõem-se estas imagens atuais das vias em conjunto com mapeamentos das leis no perímetro de estudo, a fim de se permitir a visualização em planta das áreas centrais específicas abrangidas pela legislação ao longo do século XX.

O mapeamento da legislação foi agrupado em 10 períodos diferentes de acordo com a criação e predominância de conjuntos de leis, buscando-se facilitar a visualização de sua aplicação. Foram utilizadas como suporte as plantas, mapas e aerofotogrametrias de cada período. As escalas destas peças cartográficas, produzidas de 1800 até 1974 foram compatibilizadas com base no trabalho do Prof. Dr. Jorge Pimentel Cintra, da Escola Politécnica, que evidencia três distâncias de referência no centro histórico:

a) 717,1 metros do Mosteiro de São Bento até o Convento de São Francisco;

b) 792,2 metros do Convento de São Francisco até o cruzamento da Rua Silveira Martins (antiga Rua das Flores) com a Rua Tabatinguera;

c) 1.003,3 metros do cruzamento da Rua Silveira Martins (antiga Rua das Flores) com a Rua Tabatinguera até o Mosteiro de São Bento.

Após cada mapeamento, foram itemizadas as leis a fim de resumirem-se suas principais prerrogativas, viabilizando sua comparação não apenas com os registros fotográficos expostos neste capítulo, mas também com os edifícios estudados e expostos mais adiante, no anexo 1, cuja localização está presente nestes mapeamentos. 
Figura 78 - Planta da cidade de São Paulo - 1800 / 1874

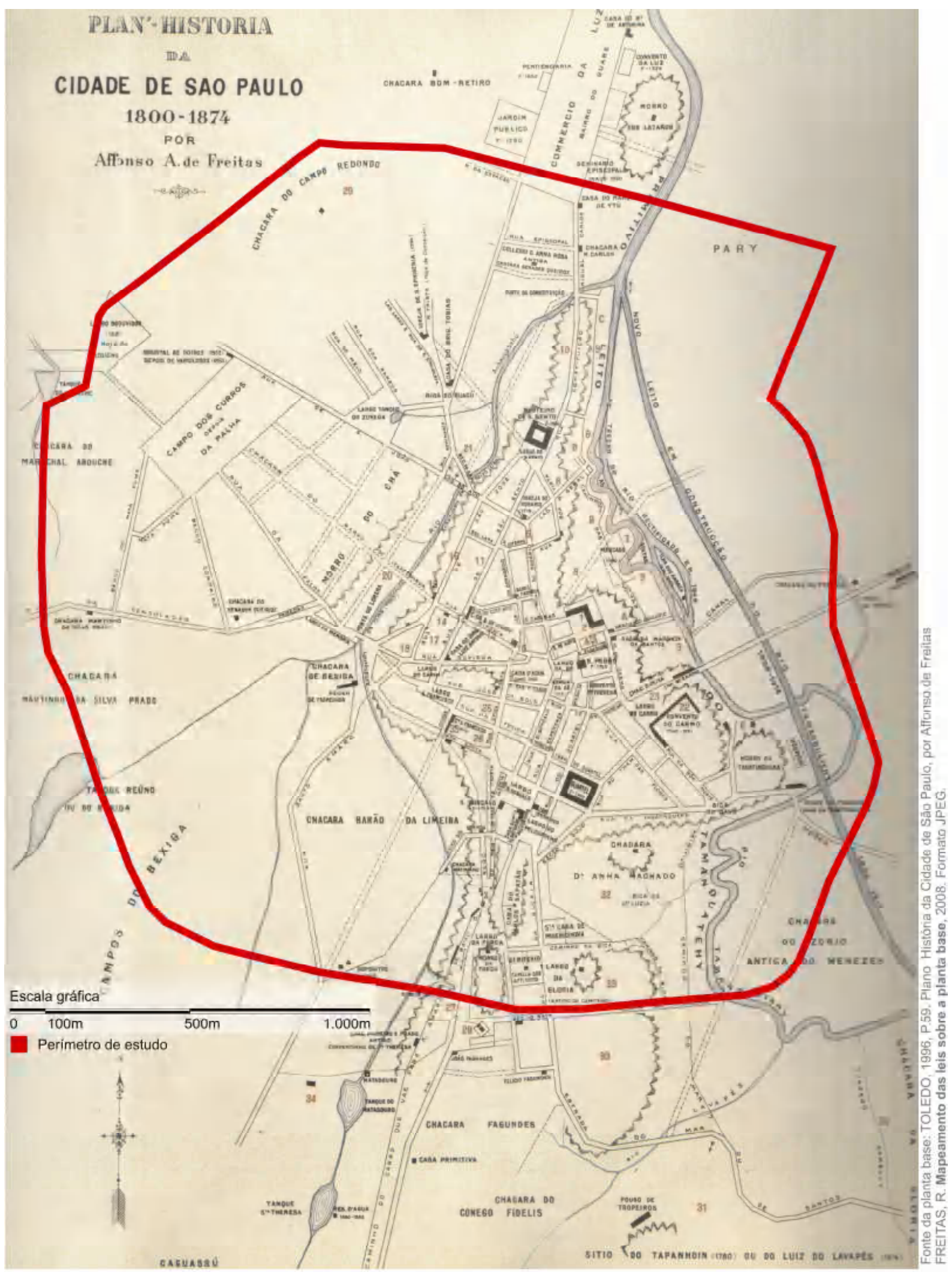

Regulamentaçōes aplicadas ao Município:

Até 1603 - Ordenaçőes Afonsinas / Manuelinas; 1603 a 1750 - Ordenação Filipina / Lei Zenon (código justiniano VIII, de 490 d.C.); 1886 - Código de Posturas do Municipio 
Leis mapeadas na página anterior sobre planta da cidade de São Paulo de 1800 / 1874:

Ordenações Filipinas (a partir de 1603), baseadas nas Ordenações Manuelinas e Afonsinas, definiram:

- largura mínima: 1,375m das vielas entre prédios vizinhos;

- faixa de servidão mínima: 0,44m medida entre os pontos onde caíssem as águas do telhado, entre prédios vizinhos, não separados por vielas.

Código de Posturas do Município de São Paulo (1886), definiu:

- largura mínima de ruas: 16m;

- largura mínima de avenidas: 25m;

- edifícios no alinhamento frontal do lote, compulsoriamente;

- alturas dos andares: $5 \mathrm{~m}$ no $1^{\circ}$ pavimento; $4,88 \mathrm{~m}$ no $2^{\circ} ; 4,56 \mathrm{~m}$ no 3ㅜㅜ;

- altura máxima do prédio: 17m;

- portas: 1,3 x 3,2m; janelas 1,1 x 2,2m;

- soalho: $50 \mathrm{~cm}$ acima do nível do terreno;

- saliências: $15 \mathrm{~cm}$ - embasamento; $30 \mathrm{~cm}$ - sacadas do $1^{\circ}$ pavimento; $1,0 \mathrm{~m}$ - balcões do $2^{\circ}$ pavimento; $1,8 \mathrm{~m}$ - balcões do $3^{\circ}$ pavimento; $15 \mathrm{~cm}$ - cornijas. 
Figura 79 - Planta do centro de São Paulo, 1897 - leis de 1893 a 1904

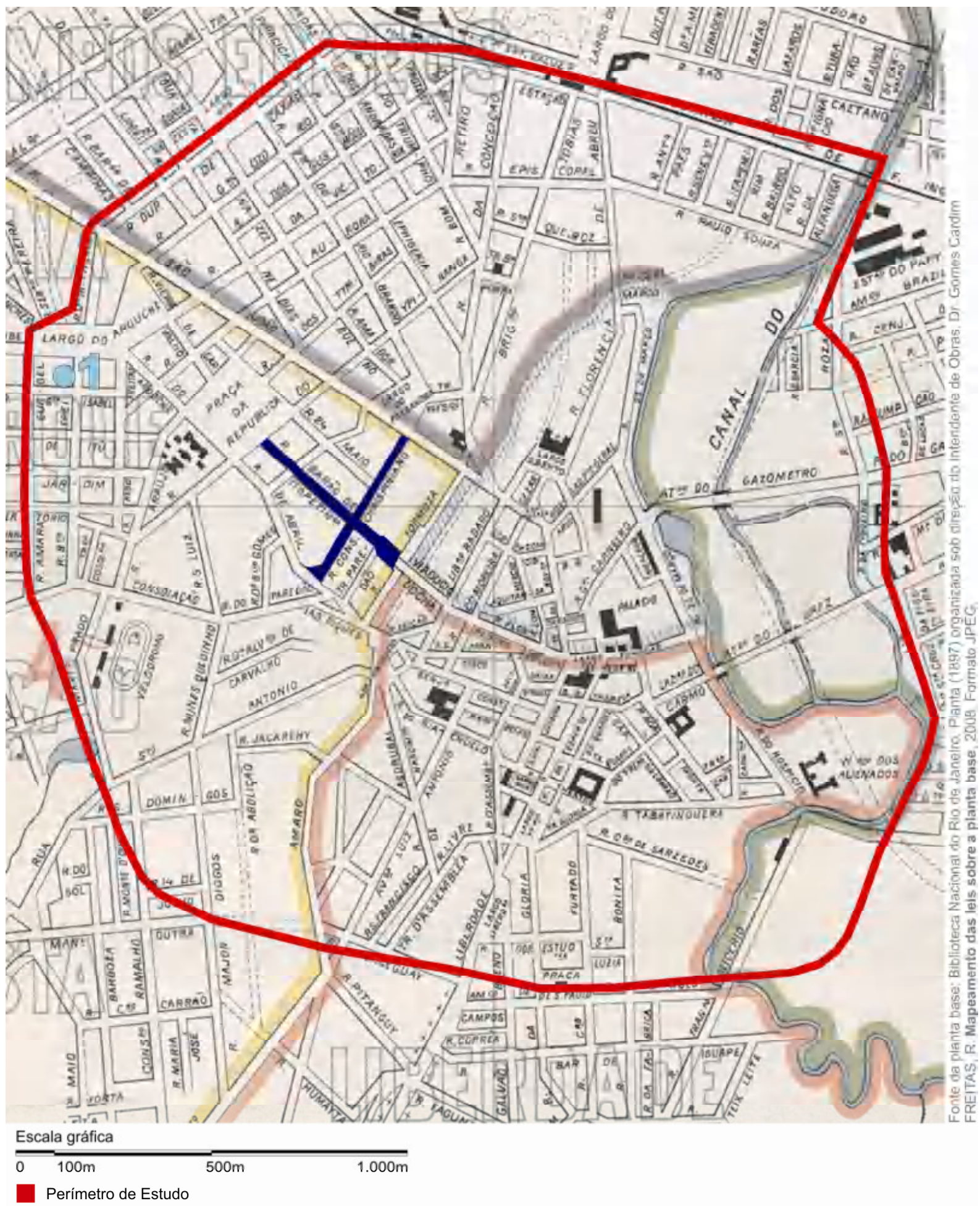

Regulamentações aplicadas ao Municipio:

1893 - Lei $n^{\circ} 38 ; 1894$ - Decreto Estadual $n^{\circ} 233$;

1896 - Lei n 220; 1896 - Lei n² 274; 1900 - Lei n 498; 
Leis de 1893 a 1904 mapeadas na página anterior sobre planta do centro de São Paulo de 1897:

Lei no. 38 (1893):

- paredes principais do último pavimento da construção: espessura mínima de $30 \mathrm{~cm}$, adicionando-se $15 \mathrm{~cm}$ na espessura de tais paredes, em cada um dos pavimentos subseqüentes abaixo do superior;

- compulsória aprovação de plantas de novos edifícios pela Intendência Municipal;

- compulsória iluminação e aeração de dormitórios nas residências;

- largura mínima de 16m para novas ruas;

- praças e jardins públicos deveriam ser quadrados.

\section{Decreto Estadual no 233 (1894) Código Sanitário do Estado de São Paulo:}

Baseado na legislação sanitária européia, serviu como modelo para a legislação paulista.

\section{Lei no 220 (1896):}

Reforçou a obrigatoriedade do respeito ao Código de Posturas de 1886 e do Código Sanitário 1894, prevendo demolição de edifícios fora do padrão de construções.

\section{Lei no 274 (1896):}

Regulamentava a altura mínima de 2,20m a partir do passeio para a instalação de toldos nas fachadas dos edifícios.

\section{Lei no 498 (1900):}

- área de ventilação e iluminação das construções, interna ao lote, mínima de $10 \mathrm{~m}^{2}$, com lado mínimo de $2 \mathrm{~m}$, para a qual os compartimentos internos à construção teriam aberturas correspondendo a $20 \%$ da área do ambiente;

- espessura mínima de $45 \mathrm{~cm}$ para as fundações, aumentando-se nesta espessura $15 \mathrm{~cm}$ para cada pavimento (Lei no 38 de 1893).

\section{Lei no 761 (1904):}

- incentivo fiscal a edifícios construídos até 1906 seguindo o Padrão de Fachada da Prefeitura de São Paulo, nas ruas Barão de Itapetininga e Conselheiro Crispiniano. 
Figura 80 - Rua Conselheiro Crispiniano

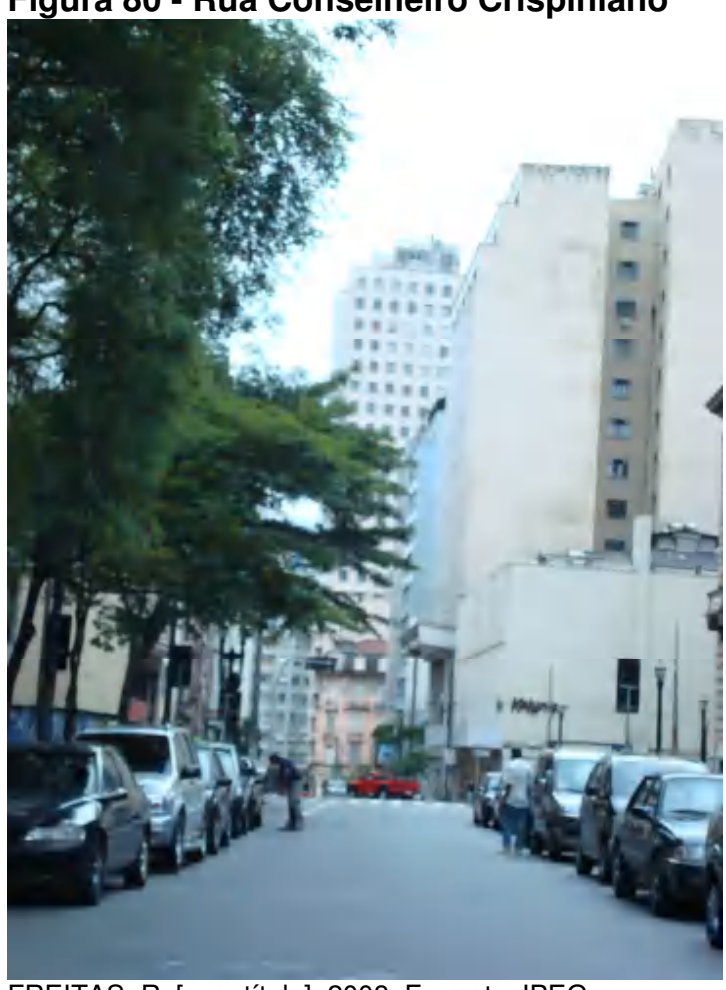

FREITAS, R. [sem título], 2008. Formato JPEG
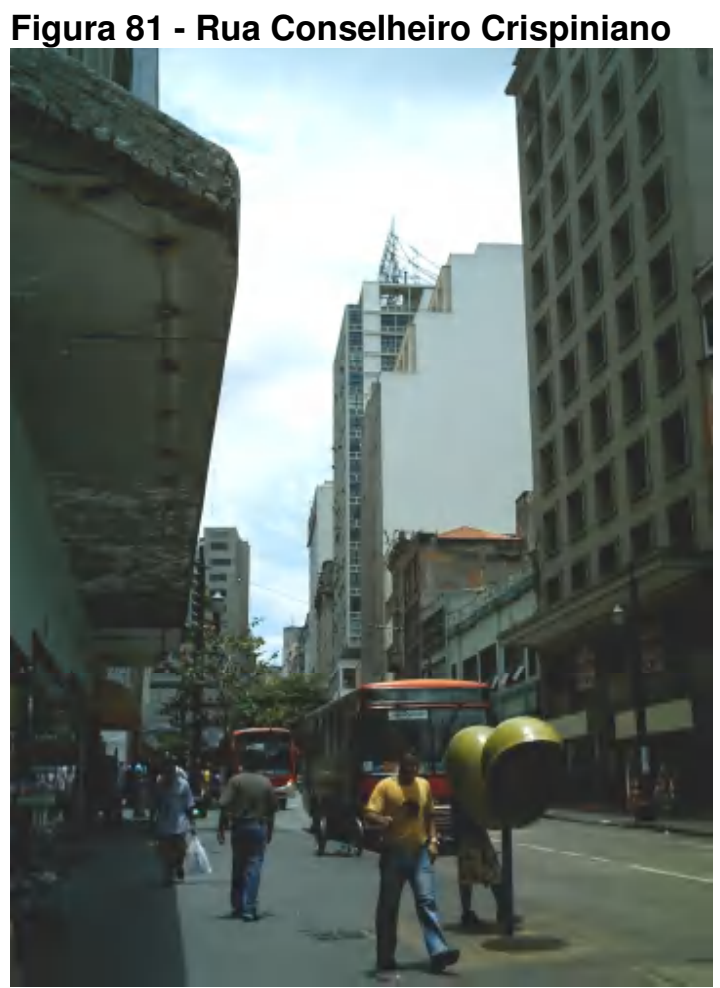

FREITAS, R. [sem título], 2008. Formato JPEG

Verifica-se nas imagens acima que a pretensão da Lei no 761/1904 de uniformização das fachadas à Rua
Conselheiro Crispiniano não se percebe atualmente.

Estas fotografias ressaltam o impacto visual da volumetria resultante de lotes edificados sob as regras legais criadas e alteradas ao longo do século $X X$. Supõe-se que, se o texto da lei de 1904 surtiu efeito em algum momento da história - como nas edificações de menor porte da imagem abaixo - a revisão das normas descaracterizou 0 resultado harmônico que talvez tenha existido entre as fachadas desta via.

Em 1934, o Ato no 663 estabeleceu que as construções desta rua deveriam ter altura mínima resultante da construção de térreo mais quatro pavimentos, sendo a altura máxima de 10 andares além do térreo.

Atente-se para as edificações à direita destas fotos, como resultado da aplicação do Ato no 1366 de 1938, que estabeleceu a obrigatoriedade de edificação de prédios com térreo e mais 10 pavimentos nesta via. Este ato de 1938, além de obrigar os proprietários a edificarem suas novas obras com esta altura mínima, se contrapôs à lei de 1904 e à lei de 1934. 
Nas fotos da página anterior, as mesmas edificações à direita das imagens, têm área de ventilação interna ao lote, para a qual voltam-se as janelas dos ambientes internos, seguindo critério aplicado desde 1900, com a Lei no 498. Seu escalonamento a partir do $10^{\circ}$ andar define sua data de construção provável como a partir de 1934, quando escalonando-se as edificações a partir de sua altura mínima compulsória seria possível chegar à altura de 50 metros.

Figura 82 - Rua Barão de Itapetininga

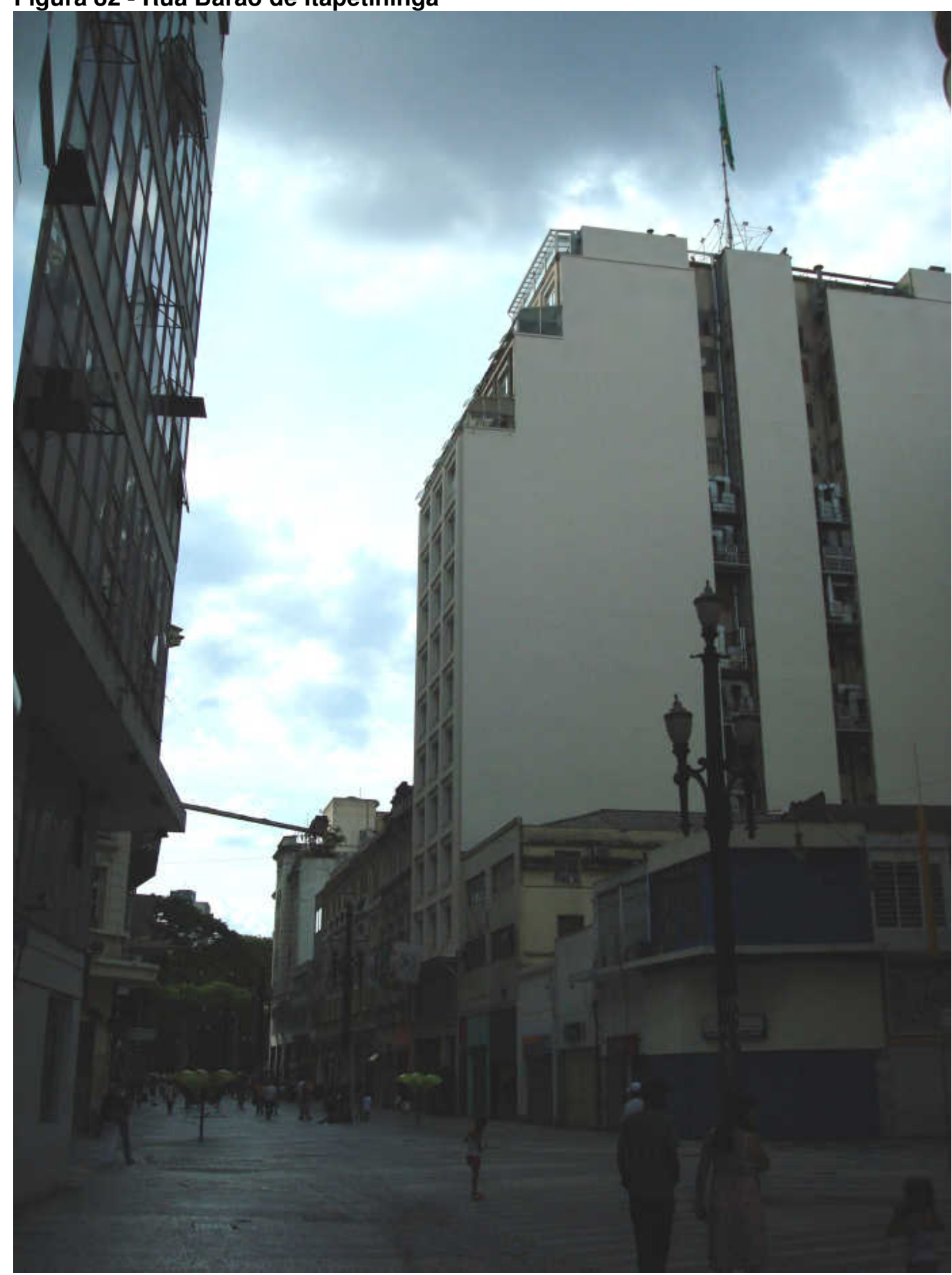

FREITAS, R. [sem título], 2008. Formato JPEG 
A imagem da página anterior retrata a descontinuidade das fachadas à Rua Barão de Itapetininga, contrariamente ao que os legisladores pretendiam quando criaram a lei de incentivos fiscais de 1904. Possivelmente as construções à direita do grande edifício tenham sido construídas antes de 1920 com térreo e mais três pavimentos, seguindo o padrão municipal de fachadas, em função dos incentivos fiscais propostos nas leis de 1904 a 1906. Se fossem construções erguidas após 1920 teriam térreo e mais quatro pavimentos, de acordo com a Lei ํㅡㄴ 2332.

Deste modo, entende-se que todas as construções da Rua Barão de Itapetininga que têm menos de quatro pavimentos, além do térreo, são anteriores a 1920, bem como seus lotes, definidos sem levar em consideração os critérios de dimensões mínimas para loteamentos introduzidos nas leis de 1920, 1929, 1934 e 1972.

O grande edifício à direita da imagem da página anterior foi construído em concreto armado, portanto, possivelmente a partir de 1926. Entende-se que tenha sido erguido entre 1934 e 1956. De acordo com a Lei nº 3427 de 1929 este edifício poderia ter no máximo térreo mais 10 pavimentos. No entanto, com o Ato no 663, de 1934, este edifício poderia ser escalonado a partir do 10 pavimento até alcançar 50 metros de altura. Se foi construído após 1938 está de acordo com a legislação do período que obrigava os proprietários a edificarem térreo mais 10 pavimentos nesta via, em função do Ato $\mathrm{n}$ ํ 1366. O coeficiente de aproveitamento deste edifício deve estar próximo a quinze vezes a área do lote, informação que limita sua data de construção a 1957, quando a Lei no 5261 definiu coeficiente de aproveitamento máximo de seis vezes a área do lote para edificações comerciais em São Paulo.

Atenção especial pode ser dada à iluminação natural do espaço público retratado na página anterior, às 16 horas e 45 minutos do dia $1^{\circ}$ de janeiro de 2008, apesar do escalonamento dos edifícios. Percebe-se por aquela imagem que aos edifícios desta via foram aplicadas regras de ventilação e iluminação, utilizando-se áreas internas ao lote, baseadas na Lei no 498, de 1900, o que reflete a manutenção dos critérios legais do século XIX durante a criação e revisão de leis urbanas. Nota-se que as prescrições das leis de 1893 a 1904, mapeadas na planta da cidade de São Paulo de 1897, foram descaracterizadas por novas regras em menos de 40 anos, cristalizando a paisagem nesta via, como pode-se averiguar atualmente. 
Figura 83 - Planta do centro de São Paulo, 1905 - leis de 1907 a 1912

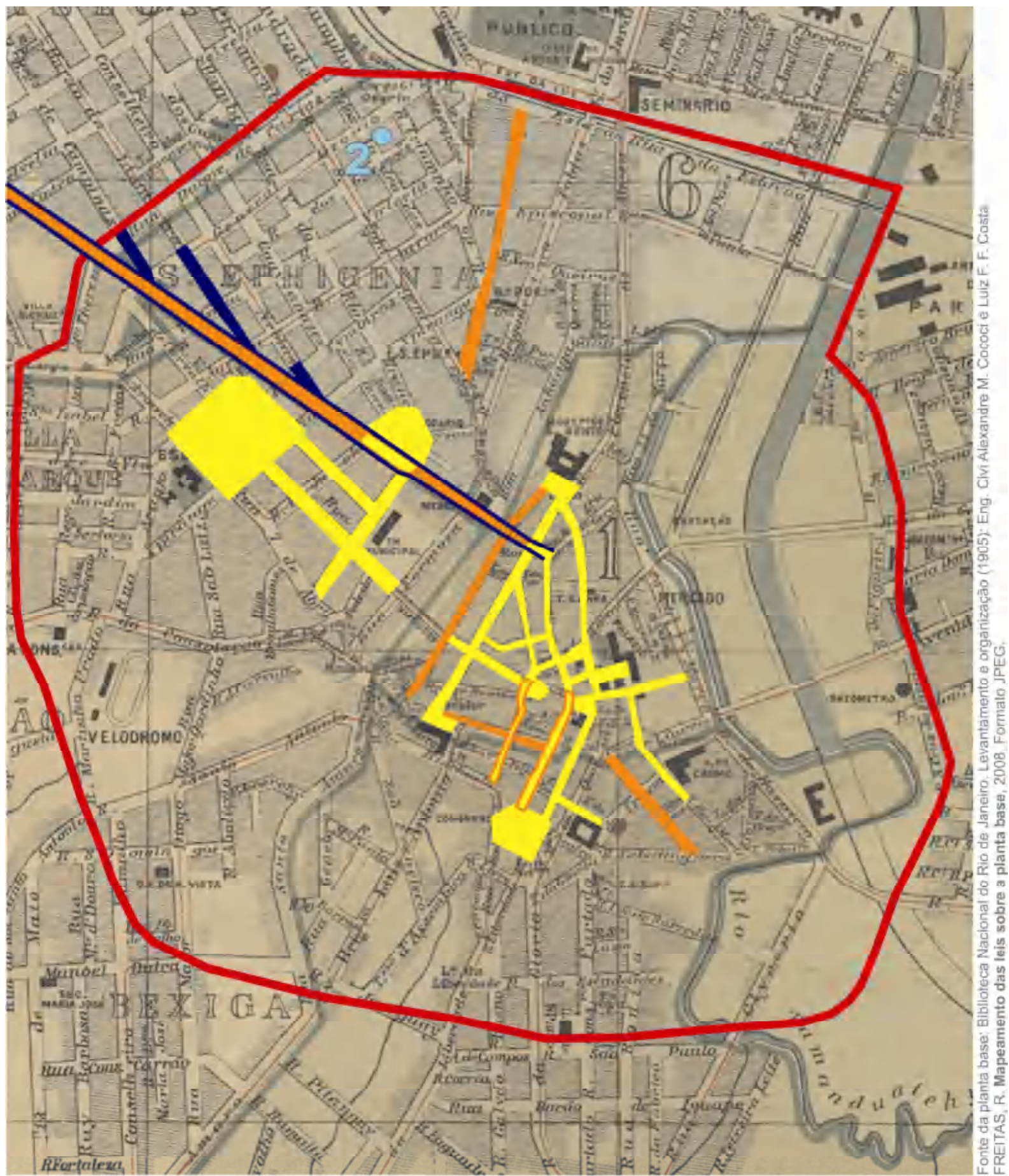

Escala gráfica

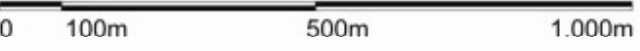

Perímetro de Estudo

1907 - Lei $n^{\circ} 1.011$

-2 1912 - Edifício à Rua dos Andradas, 492, 496 - vide Anexo 1

1912 - Lei $\mathrm{n}^{\circ} 1.585$

1912 - Lei no 1.596 
Leis de 1907 a 1912 mapeadas na página anterior sobre planta do centro de São Paulo de 1905:

\section{Lei no 1.011 (1907)}

-incentivo fiscal a edifícios construídos até 1909 com mais de 2 pavimentos, adotando fachadas aprovadas pela prefeitura, às ruas São Bento, XV de Novembro, Direita, Álvares Penteado, Quitanda, Boa Vista, Tesouro, Anchieta, Marechal Deodoro, Esperança, Quartel, Quintino Bocayuva, Fundição, Carmo, Barão de Itapetininga, Conselheiro Crispiniano, Vinte e Quatro de Maio; Largos do Tesouro, Misericórdia, Sé, São Bento, São Francisco, Palácio, Carmo, República, Paissandu; Praças João Mendes e Antonio Prado.

\section{Lei $n=1.585$ (1912)}

- fachadas com linhas mestras arquitetônicas horizontais em edificações contíguas, partindo-se da obra no ponto mais alto da quadra, às ruas Líbero Badaró, São João, Conceição, Marechal Deodoro, Capitão Salomão, Quintino Bocaiúva e Benjamim Constant. Quando em desnível na mesma quadra, linhas horizontais deveriam ser mantidas em grupos de edificações. A ruptura de linhas deveria ser disfarçada.

\section{Lei $\mathrm{n} \times 1.596$ (1912)}

- alargada a Avenida São João, cujas construções deveriam ter no mínimo 3 andares e suas fachadas aprovadas pela Prefeitura.

- prolongadas as ruas Conselheiro Nébias, Barão de Limeira e Barão de Campinas, formando três praças com a Avenida São João.

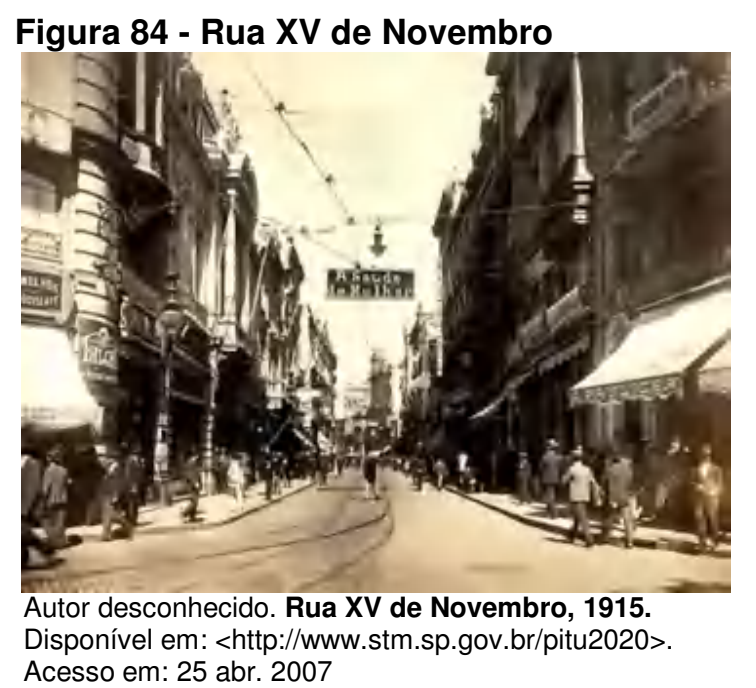


A imagem da página anterior retrata a Rua XV de Novembro em 1915, possivelmente um reflexo da aplicação dos incentivos fiscais da Lei $n$ ํ 1011, de 1907, para adoção de fachadas de acordo com o padrão municipal em edifícios com mais de dois pavimentos que deveriam ser construídos até 1909. Hoje, 100 anos após a criação desta lei, a paisagem urbana que se vê nesta rua é esta:

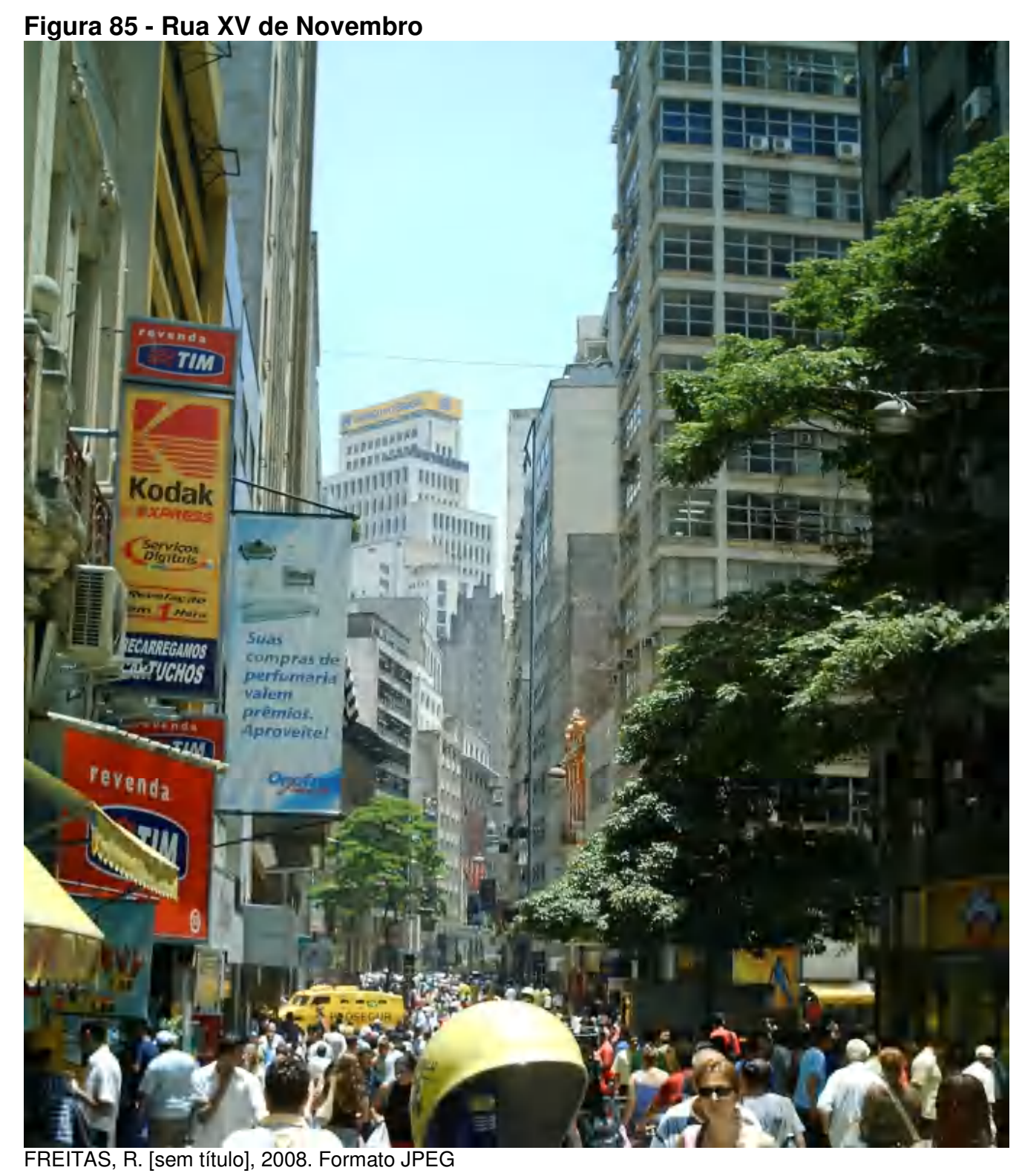

Nota-se que há edifícios construídos em períodos diferentes, ao longo do século XX, seguindo legislação urbana específica, em função de sua época. Os edifícios com térreo mais quatro pavimentos são anteriores a 1934, data em que tornou-se obrigatória a construção de prédios com no mínimo térreo mais 10 andares (de altura 3 metros) nesta rua. 
A imagem abaixo retrata os fundos da Rua XV de Novembro nos dias de hoje (2008). Passados 100 anos da criação de incentivos fiscais para harmonização da paisagem urbana neste trecho da cidade, vê-se o resultado contrário ao que se previa em 1907, fruto da aplicação de diferentes leis urbanas criadas durante o século XX. Percebe-se na imagem abaixo a contradição evidenciada na Lei no 3427 de 1929. Manteve-se a intenção de conformação da paisagem urbana a partir de fachadas frontais contíguas e alinhadas ao logradouro, conceito contraditório à permissão de obras com até 80 metros de altura, erguidas nos alinhamentos dos lotes do "centro". Nota-se uma sobreposição de conceitos: obras em concreto armado, projetadas com critérios edilícios das décadas de 1930 em diante, estruturadas por leis criadas com base em conceitos urbanísticos predominantes no cenário internacional no início do século XX. Porém, obras construídas sobre uma malha urbana com quadras parceladas em lotes de acordo com os critérios do século XIX, quando as maiores construções chegavam a alturas de no máximo 17 metros, de acordo com a lei.

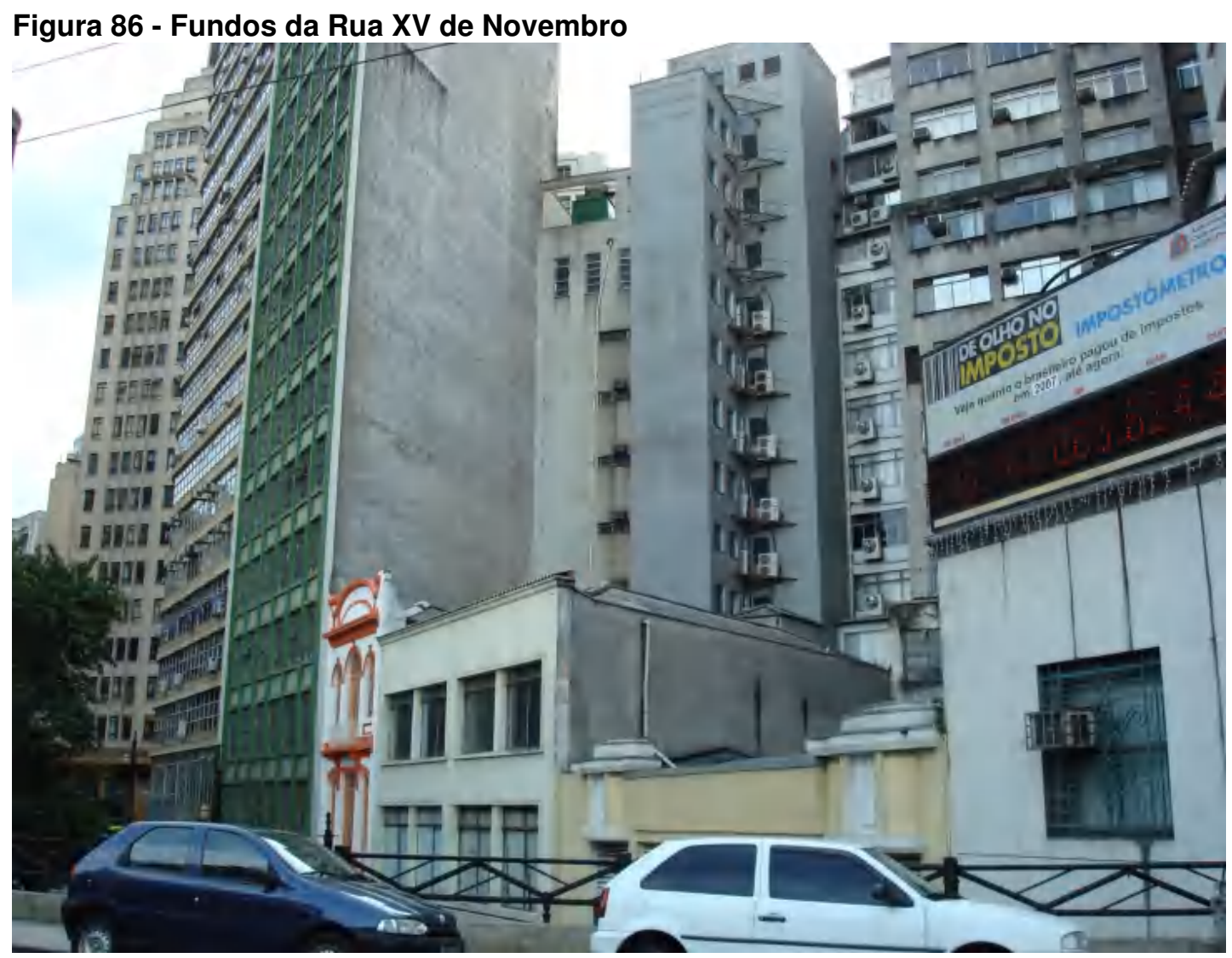

FREITAS, R. [sem título], 2008. Formato JPEG 
No período em que estatuíram-se as leis mapeadas nas páginas anteriores, repercutiam em São Paulo as obras da Avenida Central Rio de Janeiro. A Rua Líbero Badaró foi considerada como possível avenida central paulistana, que seria um espaço-vitrine de civilização e progresso a exemplo das cidades européias.

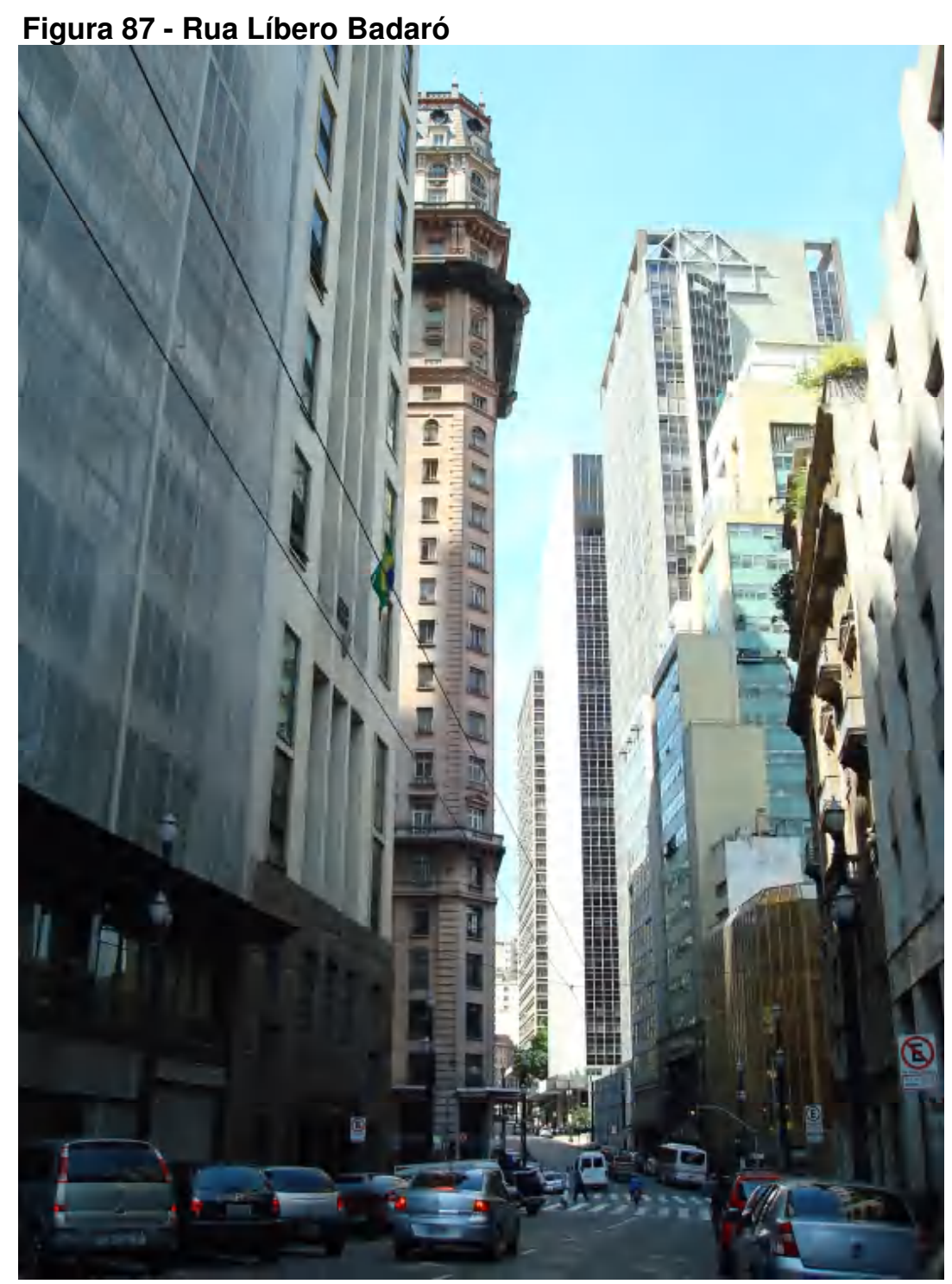

FREITAS, R. [sem título], 2008. Formato JPEG

De acordo com CAMPOS NETO (1999), a Avenida São João, retilínea, com 30 metros de largura (12 metros mais larga que a Líbero Badaró) e uma grande extensão plana, teria mais condições de se transformar numa avenida central de São Paulo. Deste modo foi objeto de tratamento estético especial, por meio de leis como a de no 1585 de 1912, que previa blocos edificados contínuos, harmonização e continuidade horizontal das fachadas e tratamentos especiais nas esquinas. Refletindo ao mesmo tempo o trajeto das grandes avenidas propostas por Alexandre de Albuquerque. 
Figura 88 - Avenida São João

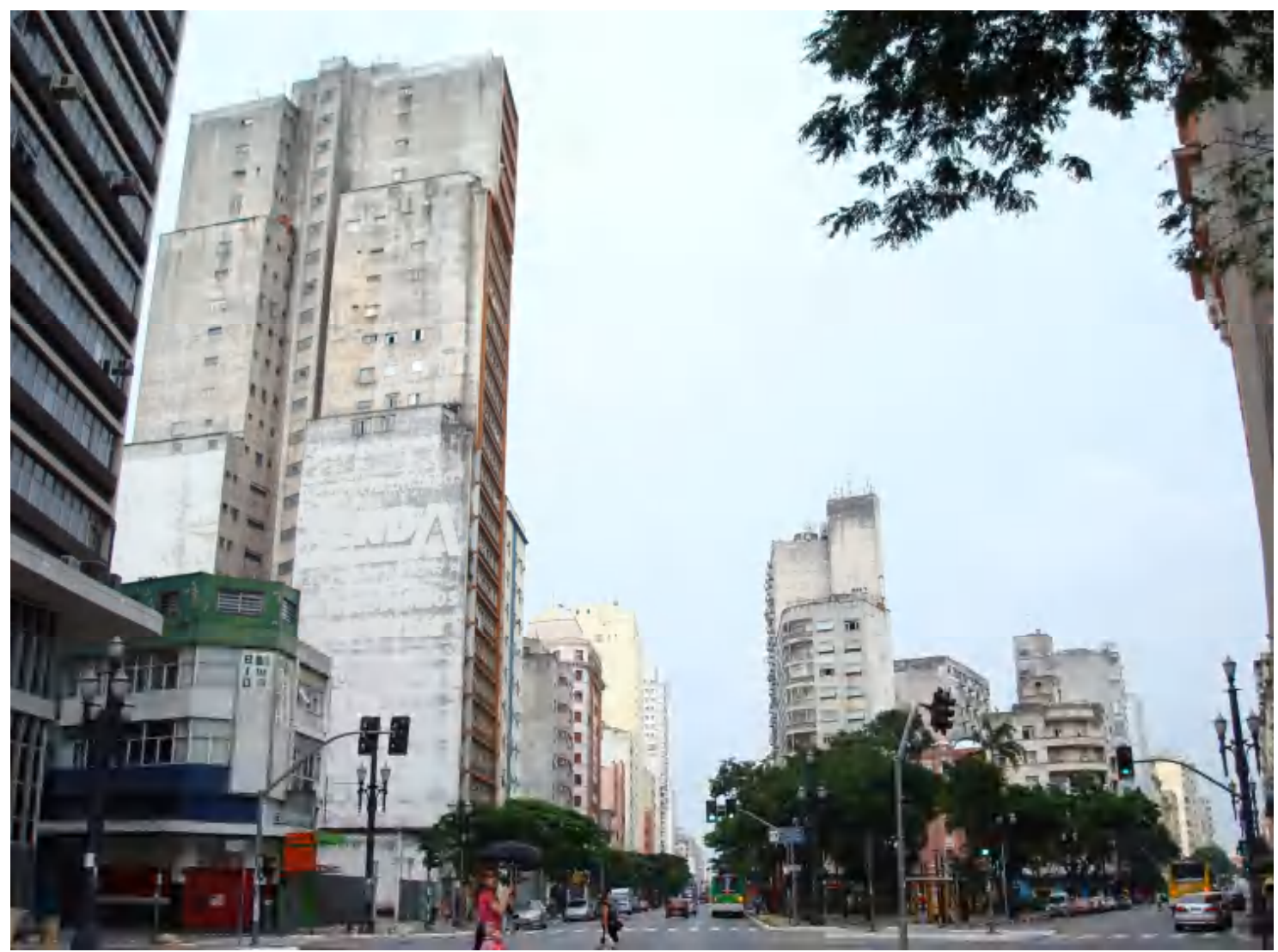

FREITAS, R. [sem título], 2008. Formato JPEG

A Avenida São João, em imagem atual, liga-se ao prolongamento da Rua Conselheiro Nébias, promovido pela Lei no 1.596 de 1912, criada quando se vislumbrava ter esta paisagem como a vitrine de São Paulo. Apesar da lei de 1912 buscar a caracterização desta a via, vê-se que à esquerda da foto acima um edifício de 23 pavimentos que segue exatamente o Decreto-lei $n^{\circ}$ 92, de 1941, que estabeleceu para esta avenida altura mínima de 39 metros (11 pavimentos, incluindo o térreo) para edifícios construídos a partir de então. Este decreto exigiu recuo lateral de 2,50 metros a partir dos 40 metros de altura e recuo lateral de 4,50 metros a partir dos 65 metros de altura. O limite de altura ficaria em 80 metros. Só haveria escalonamento frontal quando uma linha traçada a partir do lado oposto do logradouro encontrasse o limite de 80 metros em edificações entendidas pela prefeitura como um ponto focal ou de grande importância. Neste caso, estas edificações poderiam ultrapassar o limite de 80 metros de altura (exemplos visíveis na Rua Líbero Badaró). Pode-se considerar a imagem acima como a vitrine atual do "centro", pois representa sua paisagem urbana mais característica. 
Figura 89 - Planta do centro de São Paulo, 1905 - leis de 1913 a 1916

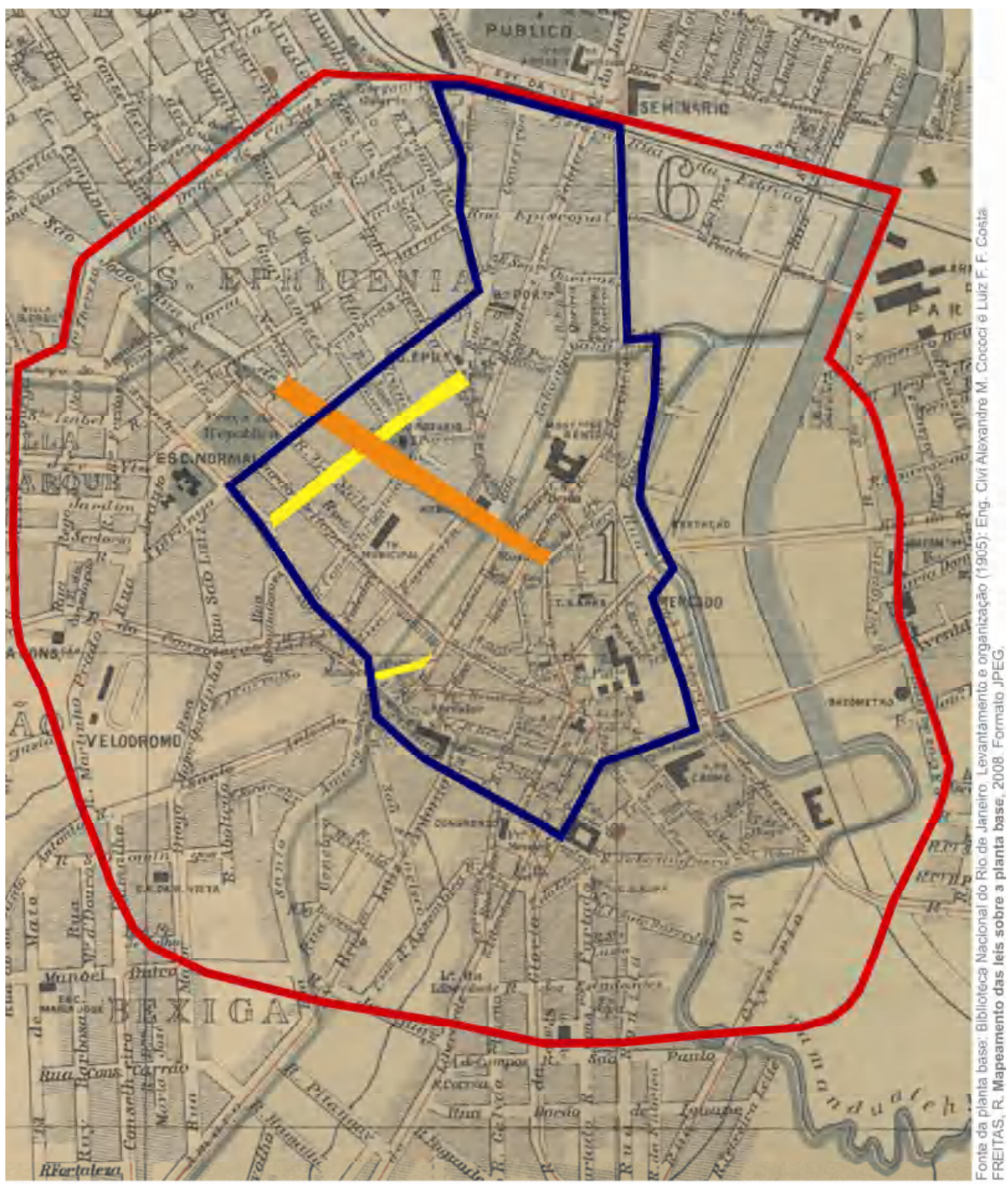

Escala gráfica
$0100 \mathrm{~m}$
$500 \mathrm{~m}$
$1.000 \mathrm{~m}$
Perímetro de Estudo
1913 - Lei $n^{\circ} 1.680$
1915 - Lei n 1.901
1916 - Ato no 900 
Leis de 1913 a 1916 mapeadas na página anterior sobre planta do centro de São Paulo de 1905:

\section{Lei no 1.680 (1913)}

- linhas arquitetônicas horizontais mantidas nas ruas Doutor Falcão e Dom José de Barros até o Largo Santa Efigênia.

\section{Lei no 1901 (1915)}

- redução de pé direito em edificações à Avenida São João, entre a Praça Antonio Prado Rua dos Timbiras.

\section{Ato $\mathrm{n} \times 900$ (1916)}

- rigorosas especificações técnicas construtivas deveriam ser seguidas nas novas obras particulares para aumentar insolação dos ambientes.

Figura 90 - Rua Dom José de Barros

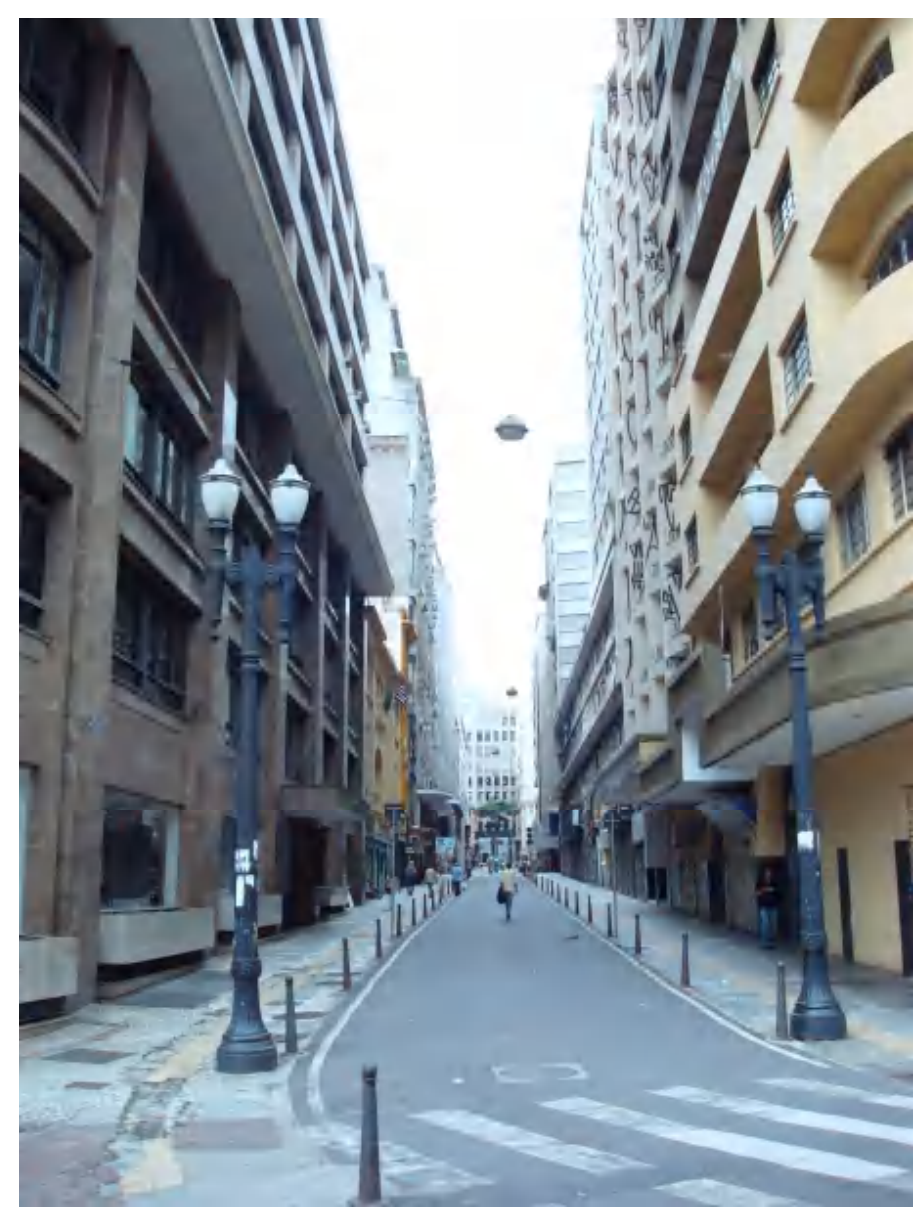

FREITAS, R. [sem título], 2008. Formato JPEG 
Verifica-se na imagem da página anterior e na fotografia abaixo que os resultados previstos na Lei ํo 1.680 de 1913 não foram descaracterizados pelas posteriores leis criadas ao longo do século $X X$, pois vê-se a presença de linhas horizontais nas atuais obras, apesar de suas alturas. Atribui-se esta ocorrência ao tamanho das testadas das obras retratadas, ou seja, suas fachadas frontais, por terem grandes extensões, têm presença marcante quando visualizadas no conjunto de obras destas vias.

Figura 91 - Rua Dr. Falcão

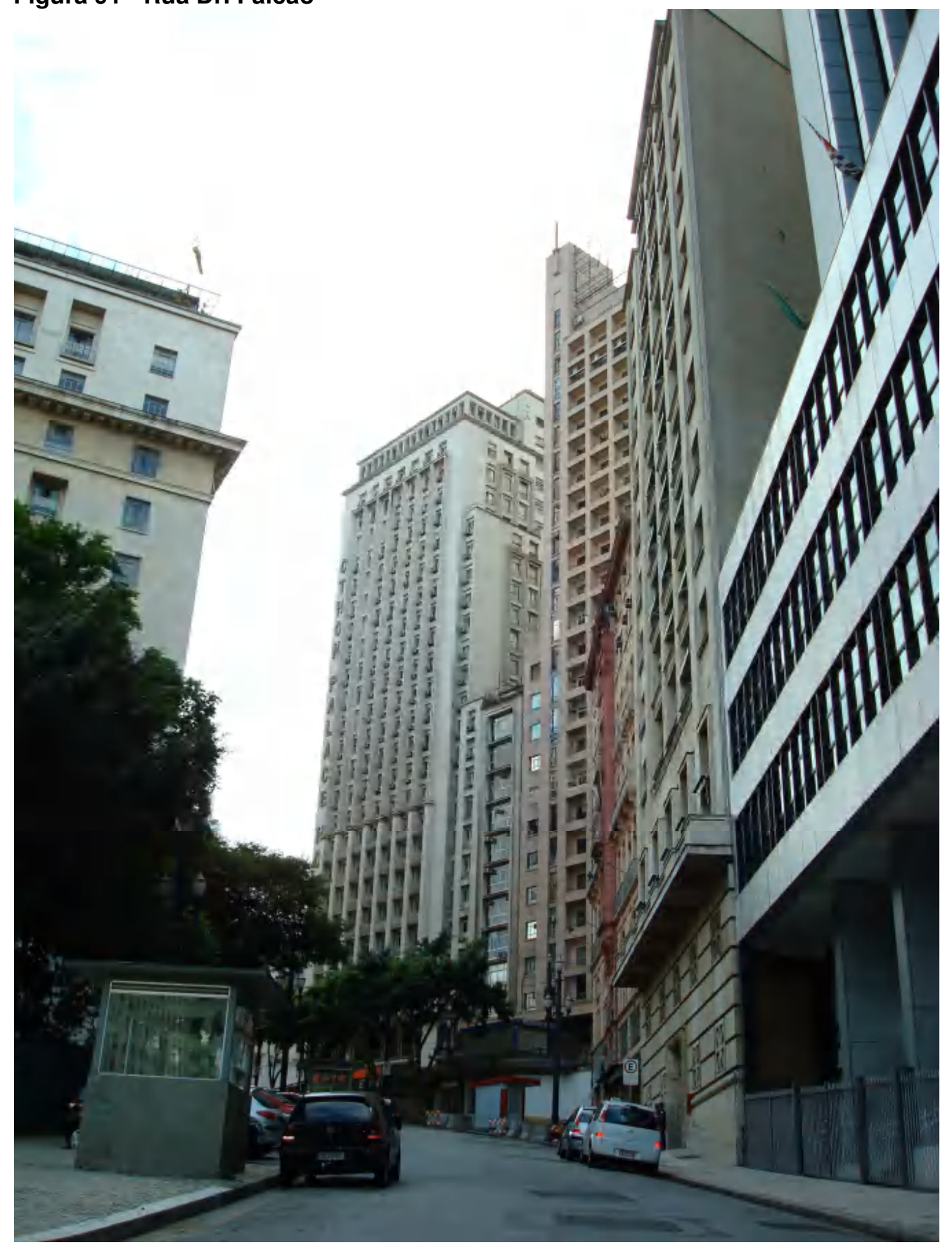

FREITAS, R. [sem título], 2008. Formato JPEG 
Figura 92 - Planta do centro de São Paulo, 1905 - leis de 1918 a 1923

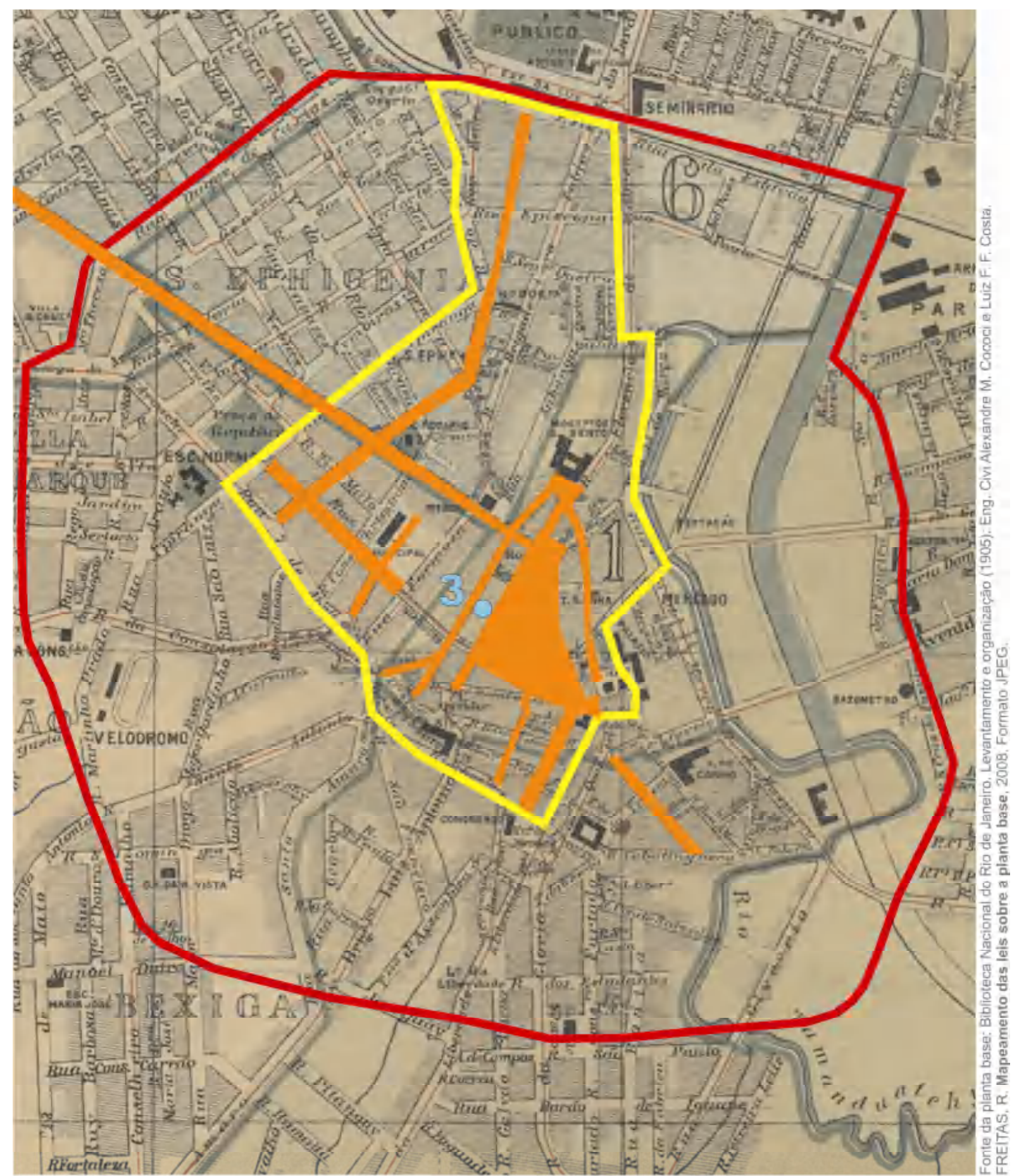

Escala gráfica

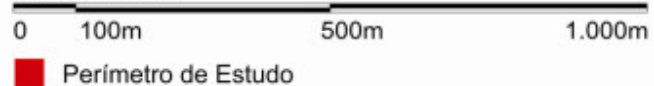

1918 - Lei $n^{\circ} 2.109 ; 1918$ - Ato $n^{\circ} 1.235$

-3 1924 - Edificio à Rua Libero Badaró, 344 a 350 - vide Anexo 1

1920 - Lei n 2.332

Regulamentações aplicadas ao Município: 1923 - Lei n² 2.611 
Leis de 1918 a 1923 mapeadas na página anterior sobre planta do centro de São Paulo de 1905:

\section{Lei no 2.119 (1918)}

- incorporou exigências higiênicas conforme Lei estadual ํㅜ 1.596 de 1917.

\section{Lei no 2.332 (1920)}

- edifícios construídos no alinhamento das vias públicas, obrigatoriamente;

- alturas: mínima 5,0m; máxima 2,0 x a largura da via se via<9m; máxima 2,5 x a largura da via, se $9 \mathrm{~m}<\mathrm{via}<12 \mathrm{~m}$; máxima 3,0 x a largura da via, se via $>12 \mathrm{~m}$;

- definiu procedimentos para obtenção do alvará de construção e determinação de peças que deveriam constar do projeto da obra a ser aprovada;

- construtores de qualquer edificação deveriam ter diploma ou título registrado na prefeitura, tendo quitado previamente impostos e emolumentos pertinentes.

- para as construções no Triângulo Comercial e ruas Marechal Deodoro, Capitão Salomão, Quintino Bocaiúva, Boa Vista, São Bento, São João, Líbero Badaró, Dr. Falcão, Dom José de Barros, Antonio de Godói, Xavier de Toledo, Barão de Itapetininga, Conceição, largos da Sé e São Bento, exigia-se no mínimo embasamento mais 4 pavimentos; continuidade das linhas mestras arquitetônicas, bem como mesmo "motivo arquitetônico";

- estabeleceu critérios específicos quanto à iluminação e ventilação;

- citou critérios básicos para instalação de elevadores;

- definiu critérios para uso de materiais de construção e alvenarias.

\section{Lei no 2.611 (1923)}

- hierarquizou e redimensionou o sistema viário em toda a cidade;

- combateu a descontinuidade da mancha urbana;

- exigiu o custeio da implantação de ruas e infra-estrutura pelos próprios loteadores, inclusive a conexão com as redes de vias existentes;

- caracterizou áreas inundáveis ou insalubres como não urbanizáveis;

- estabeleceu dimensões e condições mínimas de ocupação dos lotes: lote mínimo de $300 \mathrm{~m}^{2}$; frente maior ou igual a $10 \mathrm{~m}$; fundo maior ou igual a $24 \mathrm{~m}$; construção principal do lote com ocupação máxima de $1 / 4$ da área do lote; recuos entre frentes e fundos de $18 \mathrm{~m}$ entre construções principais. 


\section{Figura 93 - Rua Tabatinguera}

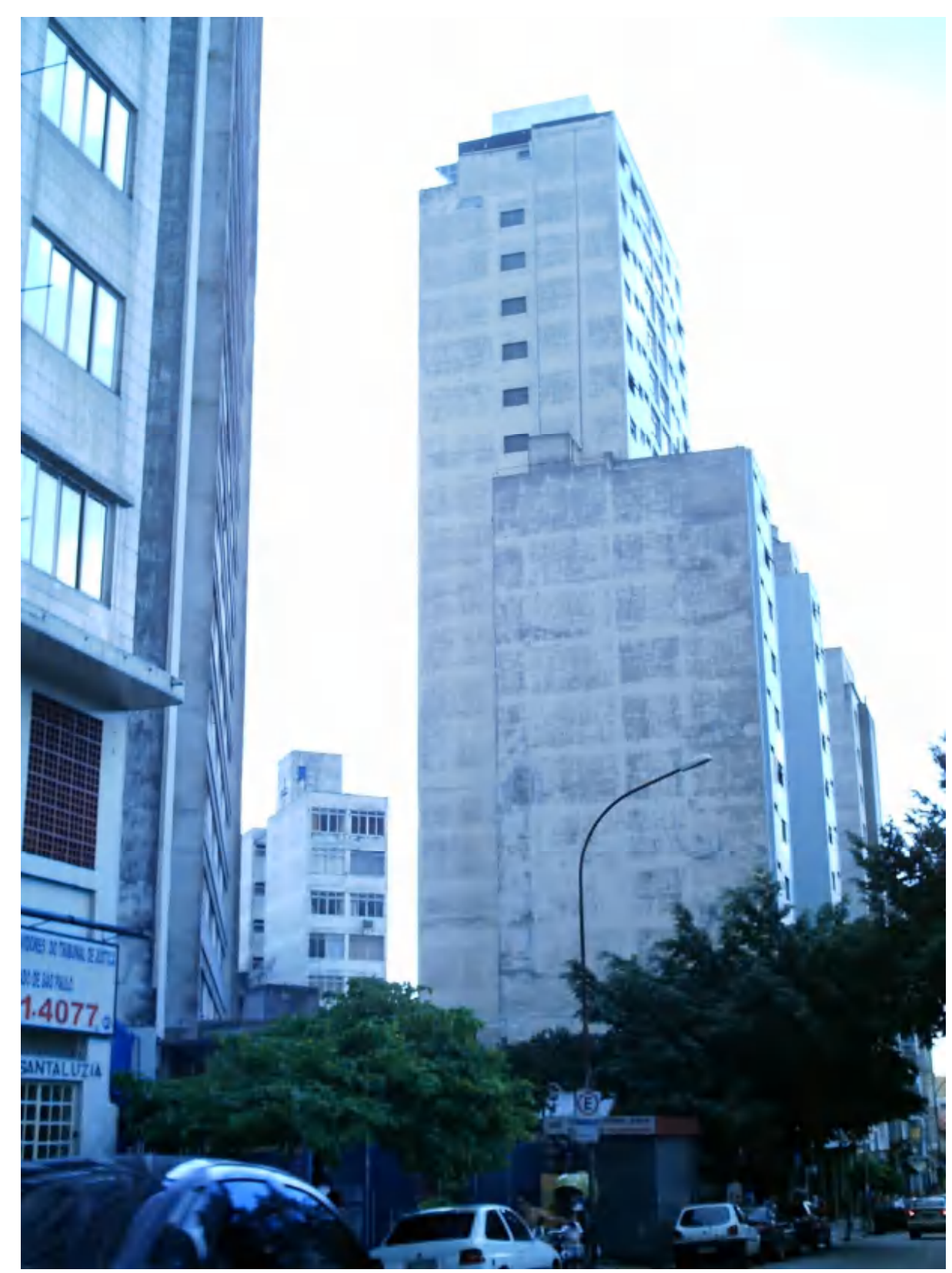

FREITAS, R. [sem título], 2008. Formato JPEG

A imagem acima retrata a obrigatoriedade de alinhamento frontal da Lei no 2.332 de 1920. Em função da técnica construtiva deste edifício, pode-se supor que tenha sido construído no mínimo quarenta anos após a aplicação dos critérios de alinhamento frontal compulsórios desde 1886. Este é o retrato da paisagem urbana, entendida neste trabalho como um fluxo, resultante do aproveitamento de lotes definidos no século XIX, cujas obras foram estruturadas por leis criadas com conceitos de coeficiente de aproveitamento do século $X X$ e conceitos de taxas de ocupação do solo urbano provenientes do século XIX, isto é, próximas de $100 \%$ do terreno. 


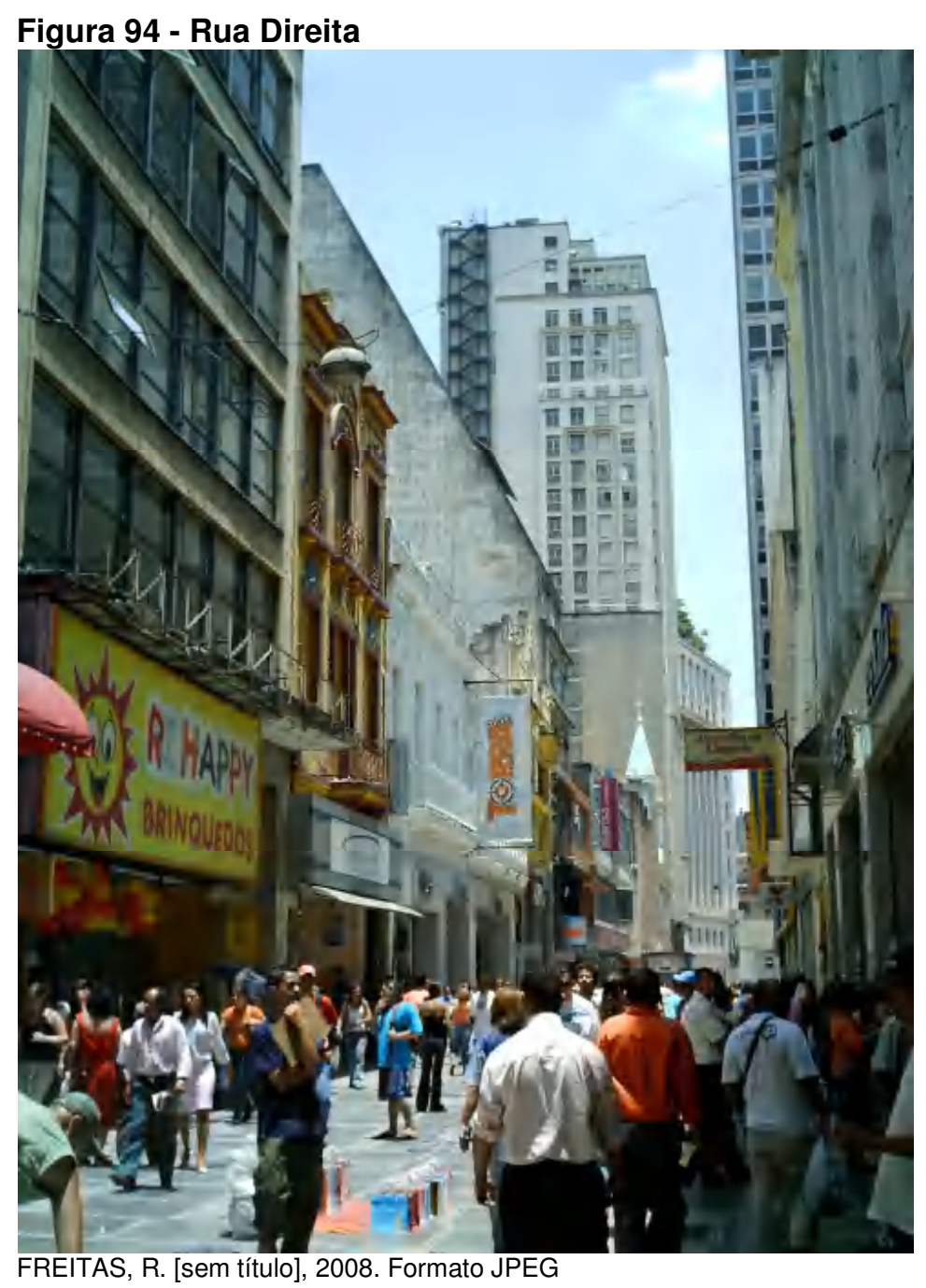

Supõe-se que as edificações retratadas acima, com menos de 4 pavimentos, tenham sido construídas antes da Lei no 2.332 de 1920 e que os prédios com térreo mais dois andares tenham sido construídos sob incentivos fiscais a partir de 1907. A construção escalonada é posterior a 1934, pois o Ato no 663 instituiu o critério de recuo do alinhamento frontal a partir do limite de altura sem recuo, estabelecido em função da largura da via. Ao fundo desta imagem, vê-se um edifício com mais de 20 pavimentos, construído antes de 1957, quando altos coeficientes de aproveitamento do solo, como este, foram proibidos pela Lei no 5261. Sua escada de emergência externa é uma adaptação à sua planta que à época de sua construção não foi projetada sob critérios legais quanto à prevenção e ao combate a incêndio, que surgiram sob a forma de decretos a partir de 1983. Evidencia-se desta maneira a descontinuidade de critérios legais aplicados em edifícios construídos no século $\mathrm{XX}$, quanto à altura e ao coeficiente de aproveitamento. Constatam-se taxas de ocupação próximas a 100\% do lote por mais de 70 anos após o fim do século XIX. 
Figura 95 - Planta do centro de São Paulo, 1930 - leis de 1929 a 1935

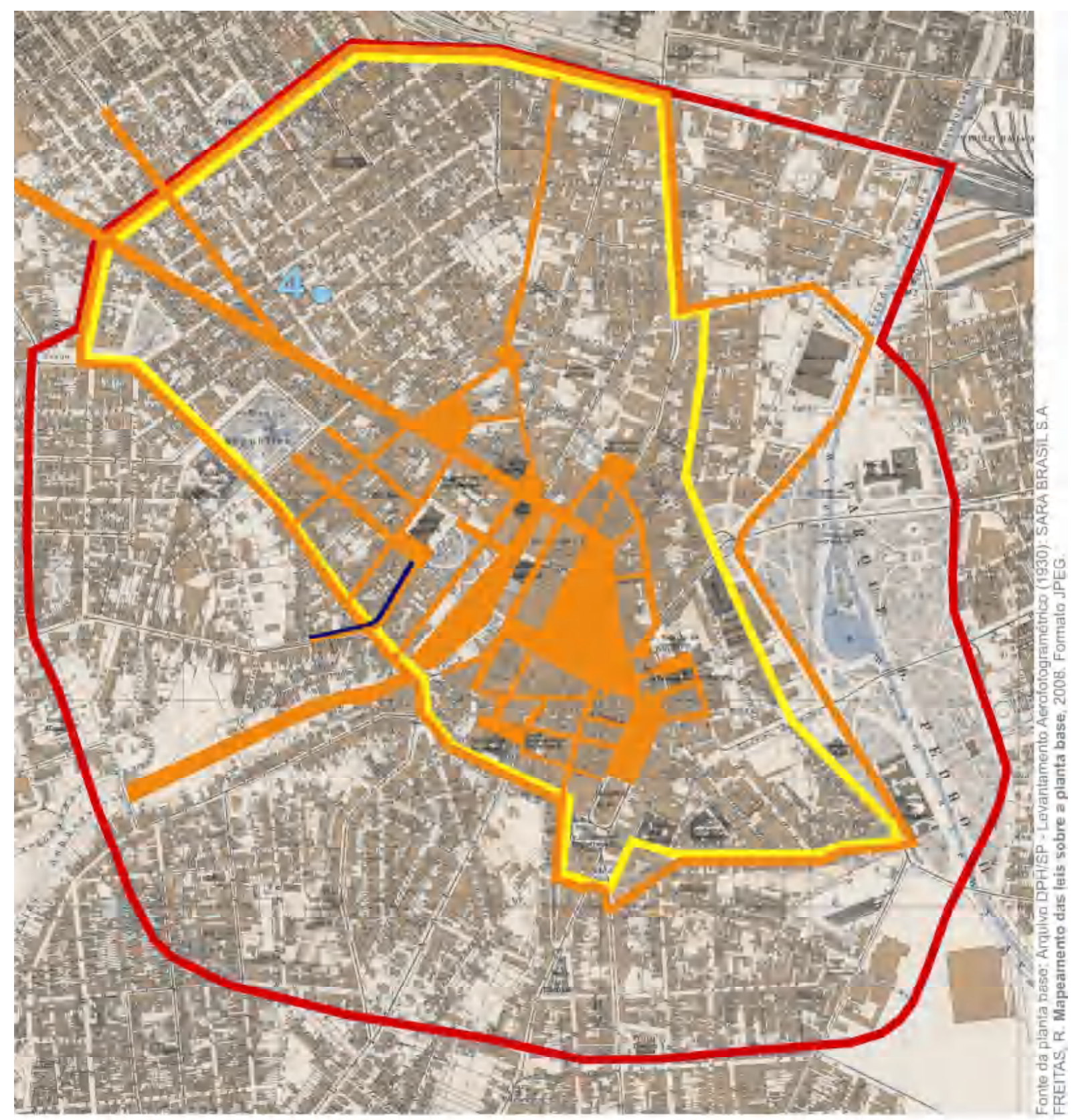

Escala gráfica

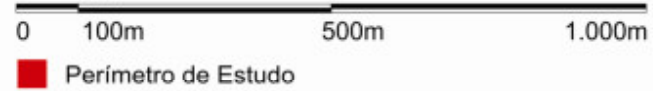

1929 - Lei $n^{\circ} 3.427$

-4 1934 - Edificio à Rua Aurora, 498 - vide Anexo 1

1934 - Ato $n^{\circ} 663$

1935 - Ato $n^{\circ} 969$ 
Leis de 1929 a 1935 mapeadas na página anterior sobre planta do centro de São Paulo de 1930:

Lei no 3.427 (1929) - vigência até 1975.

- introduziu zoneamento parcial no centro da cidade, com a construção compulsória de edifícios com mais de três pavimentos;

- repetiu essencialmente o estabelecido pelas leis 2.332/20 e 2.611/23;

- na Zona Central (do parque Dom Pedro ao Largo do Arouche e dos trilhos da São Paulo Railway ao Largo da Memória) incentivava-se a verticalização e a construção de galerias;

- alinhamento frontal compulsório para edifícios da zona central, à exceção de construções à Rua Barão de Limeira, que quando recuadas deveriam estar no mínimo a 6m do logradouro; bem como construções à Avenida do Estado, entre a Rua da Mooca e Avenida Independência, e à Avenida Carlos de Campos, que deveriam ter recuo frontal mínimo de 10m;

- manteve a Comissão de Estética como na Lei nº 2.332/20, porém evidenciando que o estilo arquitetônico e decorativo seria livre;

- definiu altura máxima de 50m para prédios e máximo de 10 andares além do térreo, às ruas Barão de Itapetininga, Xavier de Toledo, 7 de Abril, Conselheiro Crispiniano, 24 de Maio, praça Ramos de Azevedo e República;

- para as demais vias públicas a altura máxima permitida seria 80m;

- na zona central, lotes teriam frente mínima de $10 \mathrm{~m}$; lotes maiores que $300 \mathrm{~m}^{2}$ teriam a edificação principal ocupando no máximo $1 / 3$ da área do lote, enquanto lotes de $300 \mathrm{~m}^{2}$ teriam a edificação principal com projeção de $1 / 2$ da área do lote, sendo que haveria recuo de frentes e fundos de $16 \mathrm{~m}$ entre edificações principais;

- em ruas sem recuo obrigatório de construções a arborização só seria feita quando passeio fosse maior ou igual a $4 \mathrm{~m}$.

\section{Ato no 663 (1934)}

- aprovou a consolidação do Código de Obras (Arthur Saboya) de 1929, Lei no 3.427, mantendo-a em essência, com acréscimos e modificações como critérios de recuos mínimos para algumas regiões;

- manteve recuo mínimo frontal para as avenidas marginais ao Tamanduateí, entre a Rua da Moóca e a Avenida Teresa Cristina; recuo de 10m na Avenida Dom Pedro I; 
- manteve critério de altura da edificação em função da largura da via, conforme lei 2.332/20, permitindo acréscimo de altura quando seguido critério de escalonamento;

- manteve critério de insolação referenciando a Lei de 1929;

- ressaltou que o estilo arquitetônico ou decorativo seria livre, desde que não se opusesse ao decoro e às regras fundamentais da arte de construir. Recusando-se projetos em flagrante desacordo com preceitos básicos da arquitetura;

- Criou premiação anual para arquitetos e proprietários em exposição anual de fachadas;

- definiu altura mínima de 4 pavimentos, mais térreo, para prédios do Triângulo Comercial e ruas Quintino Bocaiúva, Senador Feijó, Benjamim Constant, Barão de Paranapiacaba, José Bonifácio, entre Líbero Badaró e Direita, Paulo Egídio, Floriano Peixoto, do Carmo, entre Venceslau Braz e praça João Pessoa, Venceslau Braz, entre praça da Sé e Rua do Carmo, Anchieta, General Carneiro, entre largo do Tesouro e viaduto Boa Vista, 3 de Dezembro, João Brícola, Boa Vista, São Bento, Líbero Badaró, Dr. Pádua Sales, Formosa, do Parque Anhangabaú, entre este parque e praça Ramos de Azevedo, Xavier de Toledo, Barão de Itapetininga, Conselheiro Crispiniano, 24 de Maio, Dom José de Barros, Antonio Godói, Conceição, Seminário, Capitão Salomão, Palmeiras, entre a praça Marechal Deodoro e a praça Padre Péricles; praças e largos da Sé, João Pessoa, do Tesouro, São Bento, do Café, Patriarca, do Ouvidor, São Francisco, do Correio, Ramos de Azevedo, Paissandu, Santa Ifigênia, Marechal Deodoro; Avenida São João, Anhangabaú, entre o largo da Memória e a Rua Martinho Prado; parque Anhangabaú; ladeira Dr. Falcão e travessa Grande Hotel;

- a alameda Barão de Limeira, entre a praça Júlio de Mesquita e Rua Helvetia, teria edificações sem recuo frontal e maiores que 3 pavimentos, porém no restante da alameda o recuo frontal mínimo seria de $6 \mathrm{~m}$, sem critério mínimo de pavimentos;

- definiu rígidos critérios de segurança para elevadores;

- manteve o critério de ocupação máxima de 1/3 para qualquer lote.

\section{Ato $\mathrm{n}=969$ (1935)}

- Revigorou o alargamento da Rua Xavier de Toledo foi aprovado pela Lei ㄲo. 2.332 de setembro de 1920 . A nova largura de $25 \mathrm{~m}$ foi atingida com a desapropriação dos imóveis do lado par das ruas Xavier de Toledo e Consolação. 
Figura 96 - Avenida Duque de Caxias, com Avenida Rio Branco

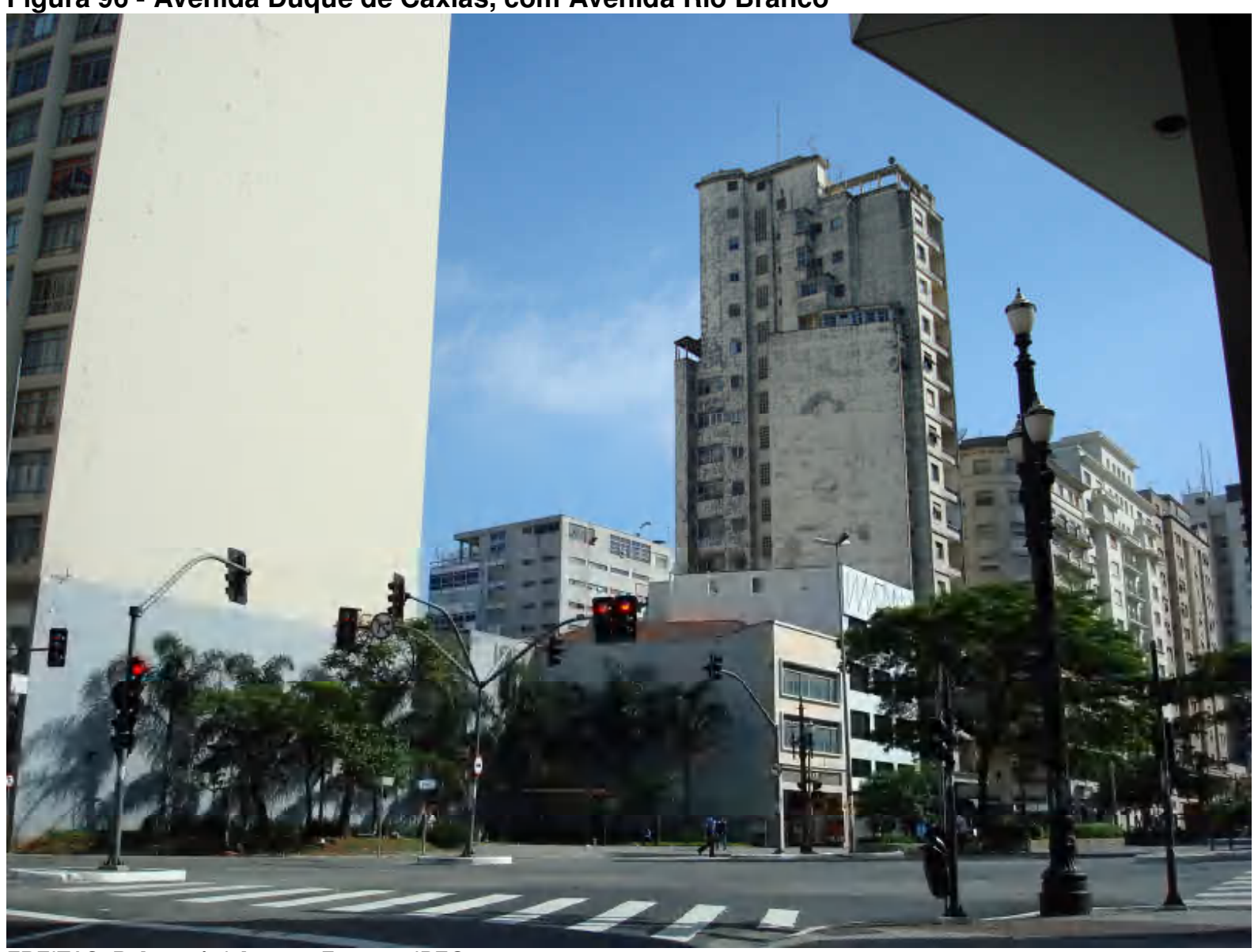

FREITAS, R. [sem título], 2008. Formato JPEG

A imagem acima retrata um dos trechos mais movimentados da cidade, 0 entroncamento das avenidas Duque de Caxias e Rio Branco. Verifica-se a aplicação do Ato no 663 de 1934, ao grande edifício à esquerda da foto, pois não foi exigido recuo lateral, apesar de ter ultrapassado dez pavimentos. De acordo com este ato de 1934 o edifício à esquerda da foto poderia ter altura de 80 metros sem recuo lateral ou escalonamento frontal, desde que para esta última medida fosse respeitado o critério de altura máxima como a largura da via vezes três. A edificação com 15 pavimentos, mais ao centro da foto, segue claramente o Decreto-lei no 92 de 1941, que estabeleceu altura mínima compulsória para edificações à Avenida Duque de Caxias, correspondendo a térreo mais 10 pavimentos. Este decreto definiu a obrigatoriedade de recuo lateral de 2,5 metros a partir dos 40 metros de altura e recuo lateral de 4,5 metros a partir dos 65 metros de altura. Como se vê na imagem acima, esta edificação não atingiu os 65 metros, mas passou dos 40 e por isso tem recuos laterais de 2,5 metros. Esta edificação tem coeficiente de aproveitamento do lote superior a dez vezes sua área. Em função de sua implantação supõe-se que sua taxa de ocupação seja próxima a $100 \%$ da área do lote. 


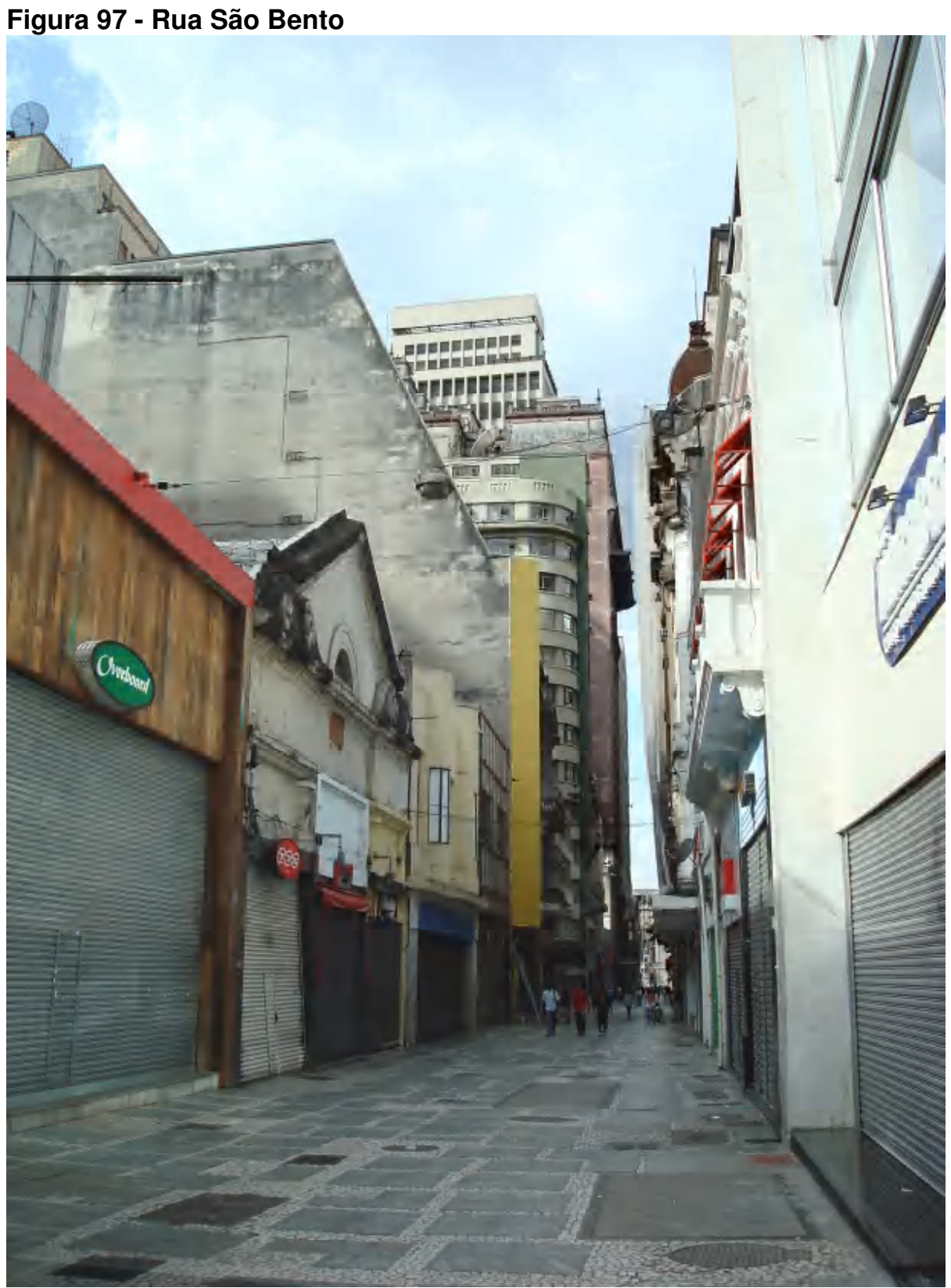

FREITAS, R. [sem título], 2008. Formato JPEG

As edificações térreas e assobradadas na foto acima são construções remanescentes do início do século XX. A edificação escalonada evidenciada ao lado segue critérios legais estabelecidos no Ato no 663 de 1934, com máximo de 6 pavimentos e posterior escalonamento. Ao fundo, na foto ao lado, vêse o edifício Martinelli, compondo a perspectiva visual da Rua São Bento.

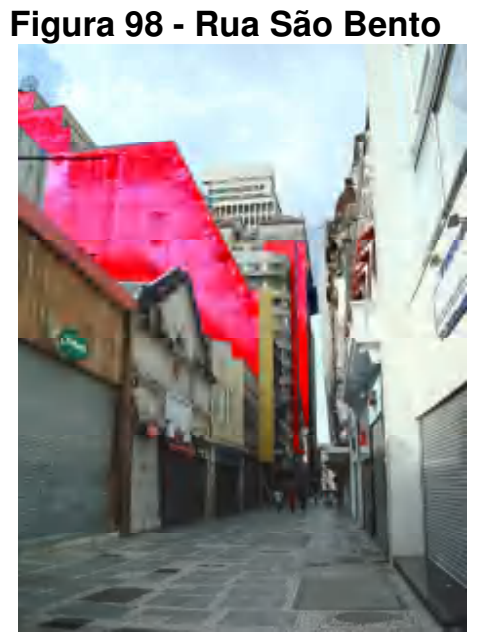

FREITAS, R. [sem título], 2008. Formato JPEG 
Figura 99 - Planta do centro de São Paulo, 1930 - leis de 1938 a 1940

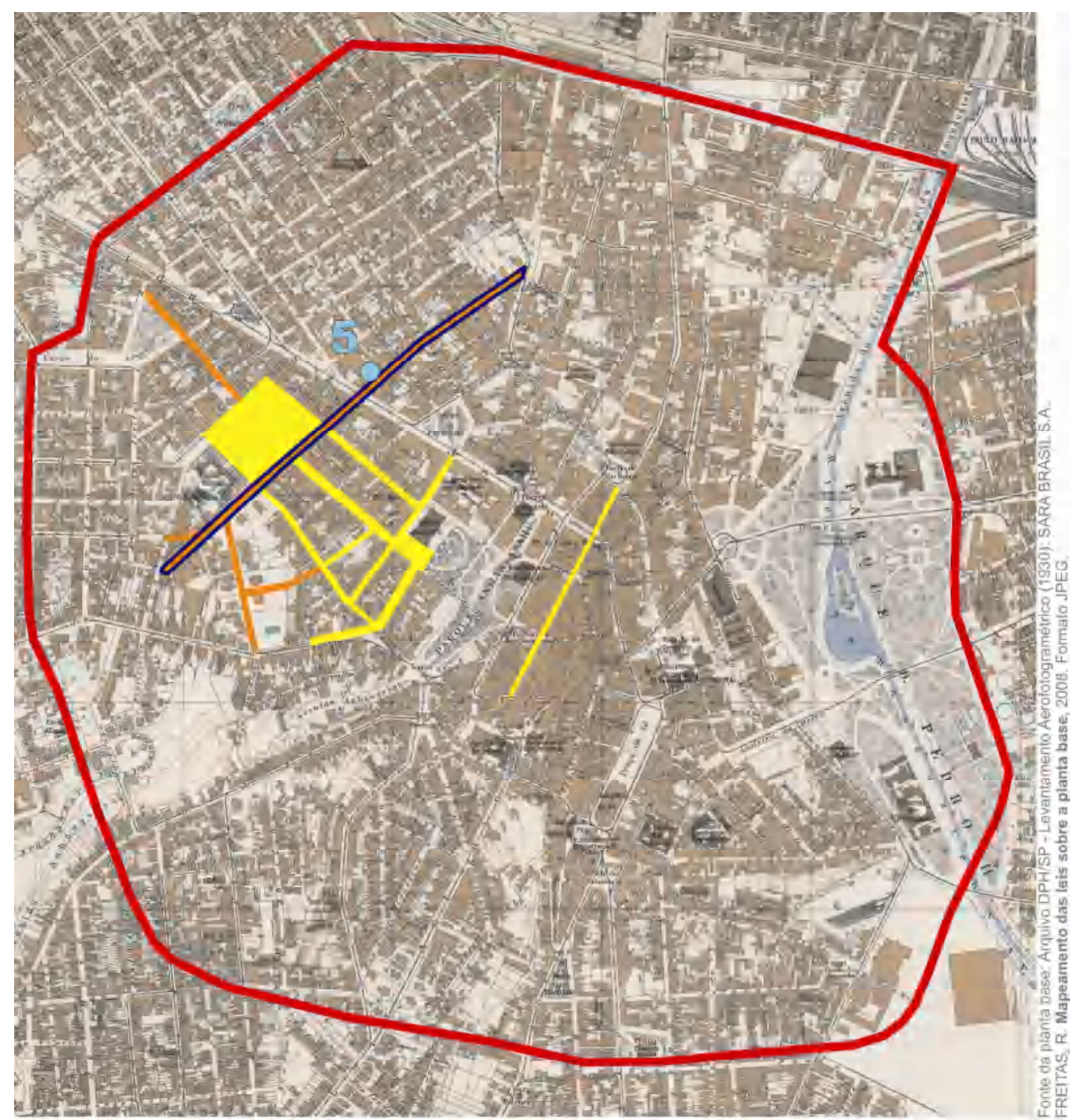

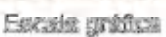

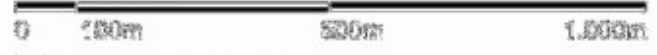

Fotrieiry des Exuslo

1938 - Ato $\mathrm{n}^{\circ} 1.366$

-55 1941 - Edificio à Avenida Ipiranga, 893 - vide Anexo 1

1938 - Ato $n^{\circ} 1.470$

1940 - Decreto-Lei no 41 
Leis de 1938 a 1940 mapeadas na página anterior sobre planta do centro de São Paulo de 1930:

\section{Ato no. 1.366 (1938)}

- estabeleceu gabaritos de altura a ruas do "Centro Novo";

- determinou a altura em relação ao número de pavimentos. Na Rua São Bento, o número de pavimentos máximo era 6. Nas ruas Barão de Itapetininga, Xavier de Toledo, 7 de abril, Conselheiro Crispiniano, Marconi, 24 de maio, na praça Ramos de Azevedo e da República deveria ter, no alinhamento frontal, 10 pavimentos com $3 \mathrm{~m}$ de pé direito, além do térreo. Acima desta altura, os prédios deveriam atender o artigo 145 do Ato n 663 de 1934. Nas ruas Marconi e Xavier de Toledo, em lote de frente menor que 20 m, os edifícios deveriam manter linhas arquitetônicas alinhadas às linhas dos lotes lindeiros.

\section{Ato $\mathrm{n}$ - 1.470 (1938)}

- "Plano de Melhoramentos Urbanos" para o "Centro Novo": alargamento das ruas Ipiranga, São Luiz e Viera de Carvalho; alargamento e prolongamento da Rua Epitácio Pessoa; prolongamento das ruas Marconi e Major Sertório.

\section{Decreto-lei no 41 (1940)}

- ruas Conceição e Consolação seriam a Avenida Ipiranga, resultante do alargamento da Rua Ipiranga, com prolongamento até a praça da República e alargamento parcial da Rua Epitácio Pessoa até a Rua da Consolação;

- 39m: altura mínima obrigatória de prédios à Avenida Ipiranga, no alinhamento, até 1950, caso contrário, acréscimo de $20 \%$ no imposto predial. Podendo crescer: até $52 \mathrm{~m}$ se recuados em $2,5 \mathrm{~m}$ a partir dos $39 \mathrm{~m}$ de altura; até $115 \mathrm{~m}$ se recuados $4,5 \mathrm{~m}$ do alinhamento a partir dos $52 \mathrm{~m}$ de altura; em esquinas maiores de $30 \mathrm{~m}$ poderiam chegar a $135 \mathrm{~m}$ de altura;

- em edifícios à Avenida Ipiranga: marquises abrigando o térreo mais sobreloja (altura total de $8 \mathrm{~m}$ ), um recuo em relação ao alinhamento frontal.

- permitiu a construção de edifícios com fachadas únicas em mais de um lote, independentemente das divisões internas de cada propriedade. Em edifícios com mais de 20 pavimentos haveria "reentrância pública" no térreo; incentivou a abertura do térreo como área pública em edifícios sem o corpo super-elevado. 
Figura 100 - Avenida Ipiranga

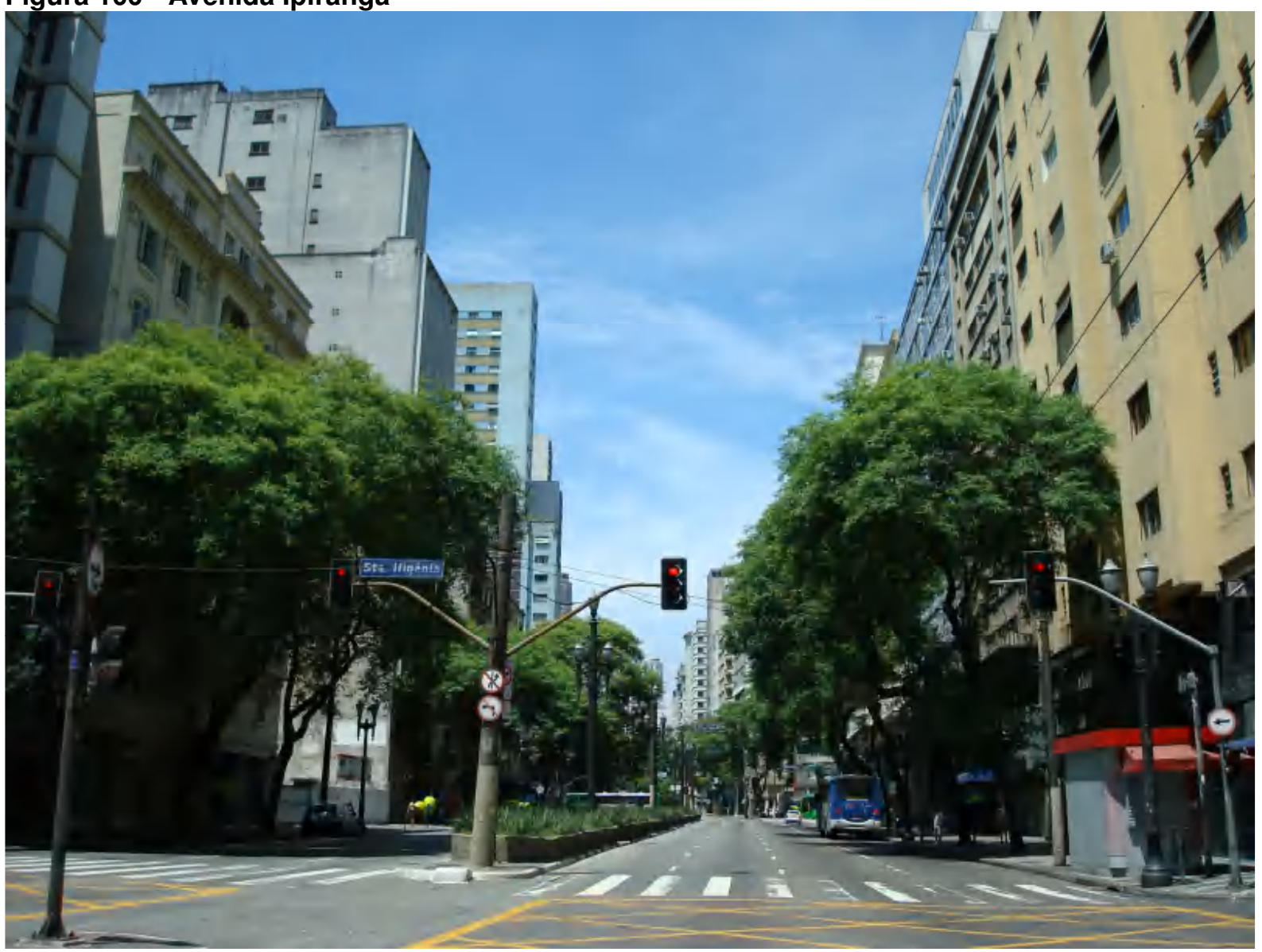

FREITAS, R. [sem título], 2008. Formato JPEG

$\mathrm{Na}$ imagem acima a volumetria consideravelmente uniformizada da Avenida Ipiranga reflete a aplicação do Decreto-Lei n 41 de 1940. Supõe-se que tenha surtido efeito o acréscimo de $20 \%$ do imposto predial para os lotes que não chegassem, até 1950 , aos 39 metros de altura mínima estabelecida por este decreto. O resultado é uma perspectiva urbana harmônica, com poucos trechos fragmentados. Nota-se no grande edifício à esquerda a aplicação exata da regra deste decreto: térreo mais sobreloja, com 8 metros de altura, alcançando-se então, com o pavimentos superiores a estes, a altura mínima de 39 metros, a partir da qual a planta do edifício passa a ocupar apenas $50 \%$ do lote. Este critério de porcentagem gerou os recuos laterais, sendo que o recuo frontal de 2,5 metros era compulsório a partir dos 39 metros de altura. Entende-se que este decreto introduziu um conceito interessante: permitiu uma única edificação em vários lotes, garantindo sua co-propriedade. Assim, incentivou-se o agrupamento de capital de vários proprietários em uma única obra, o que permitiria investimentos adequados ao porte das obras construídas sobre conjuntos de lotes, que representariam pela primeira vez no século XX uma alteração da configuração de lotes particulares existentes desde o século XIX. 
Figura 101 - Planta do centro de São Paulo, 1930 - leis de 1941

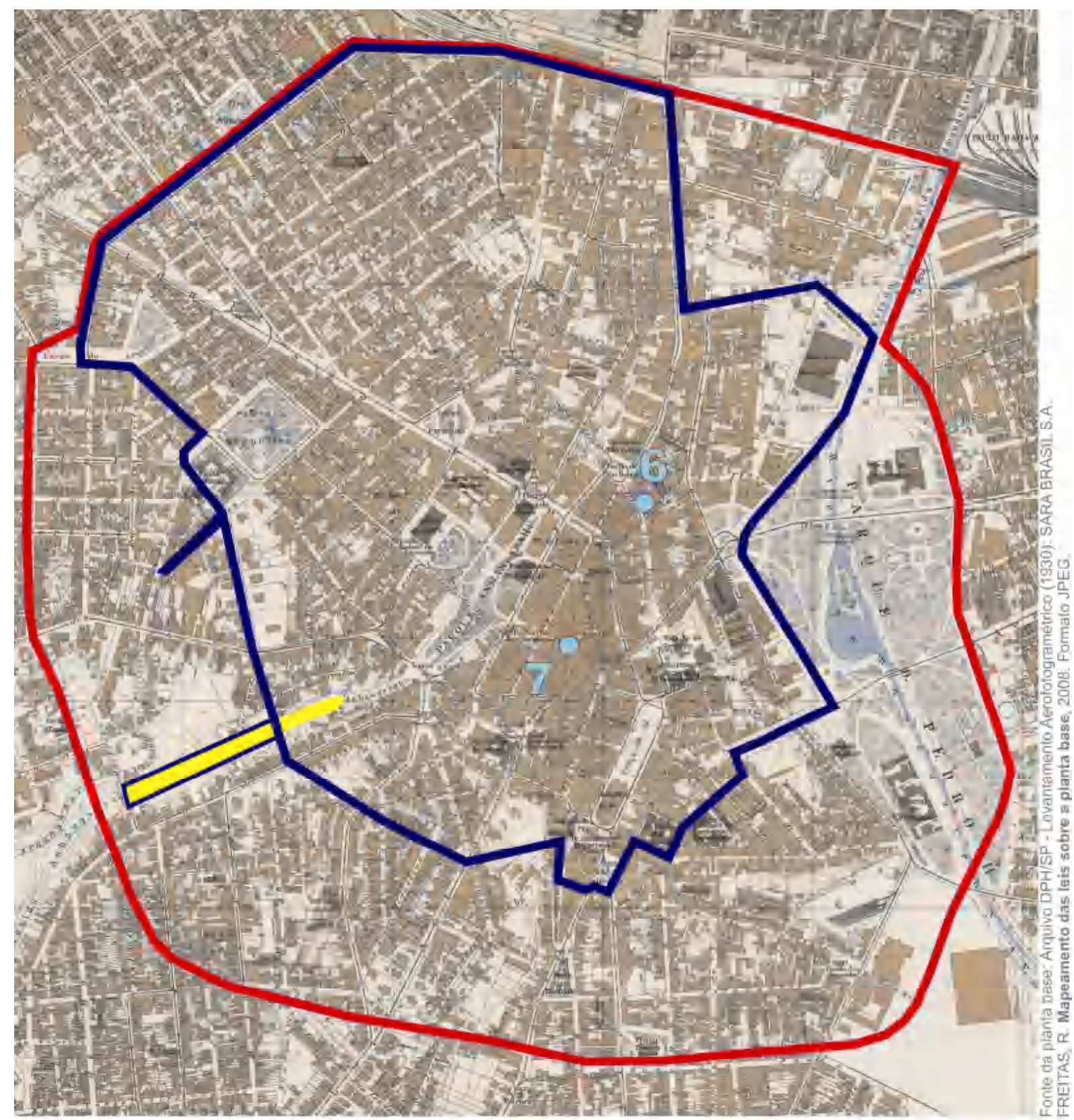

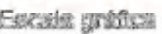

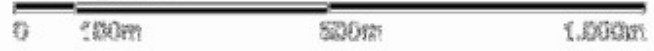

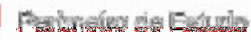

1941 - Decreto-Lei $n^{\circ} 75$

-8 1947 - Edificio à Rua Boa Vista, 304 - vide Anexo 1

1941 - Decreto-Lei nº 92 
Leis de 1941 mapeadas na página anterior sobre planta do centro de São Paulo de 1930:

Decreto-Lei no 75 (1941) - Regulamentaram-se as construções à Av. 9 de julho:

- instituiu-se um zoneamento de usos permitidos: comercial, restrito a instalação de lojas de "aspecto condigno com a natureza e importância da via;

- recuo mínimo de frente igual a 4m, podendo o térreo ser alinhado;

- poderia se construir contiguamente; construções isoladas o recuo lateral seria maior ou igual a 2m; altura mínima compulsória de 29m; máxima $80 \mathrm{~m}$, desde que escalonados em 1 para $3 \mathrm{~m}$ a partir dos $29 \mathrm{~m}$ de altura.

- permitiu-se a construção de uma única edificação em vários lotes.

Decreto-Lei n‥ 92 (1941) - Introduziu alterações no Código de Obras de 1934:

- revisou limite das alturas na área abrangida pelo perímetro de irradiação;

- alterou o perímetro da zona central estabelecido pelo Código;

- ampliou limites de altura máxima na zona central para 40m, nas ruas com até $12 \mathrm{~m}$ de largura; $60 \mathrm{~m}$ nas ruas de largura igual ou maior que $12 \mathrm{~m}$ e até $18 \mathrm{~m}$; de $80 \mathrm{~m}$ nas ruas de largura superior a 18m, estendendo a altura mínima obrigatória, de 39m (11 pavimentos incluindo-se o térreo), às seguintes vias públicas: Avenida São João, da Praça Antonio Prado até a Rua Duque de Caxias, Largo Paissandu, Praça Júlio Mesquita, Largo do Arouche, Praça da República (incluindo ruas de contorno da Escola Normal), Vieira de Carvalho e ligação com Avenida São João (rua General Osório), São Luiz (praça da república à rua da Consolação). Altura mínima de 22m, ou 6 pavimentos (inclusive o térreo), na Praça Alexandre Herculano (largo do Arouche parte inferior); Avenida São João, da Rua Duque de Caxias à Praça Marechal Deodoro; Praça Marechal Deodoro, Avenida General Olímpio da Silveira; Avenida Padre Péricles; Largo São Francisco; Avenida Rangel Pestana, da Praça da Sé ao Largo da Concórdia; Largo da Concórdia, nos novos trechos da avenida de irradiação: Rua Senador Queiroz; prolongamento da São Luiz em direção ao Viaduto Jacareí; Rua Maria Paula e seu prolongamento, nova avenida entre a Avenida Brigadeiro Luiz Antonio e Praça João Mendes; Praça João Mendes, ruas Irmã Simpliciana e Anita Garibaldi, praça do futuro Paço e Rua Mercúrio. 


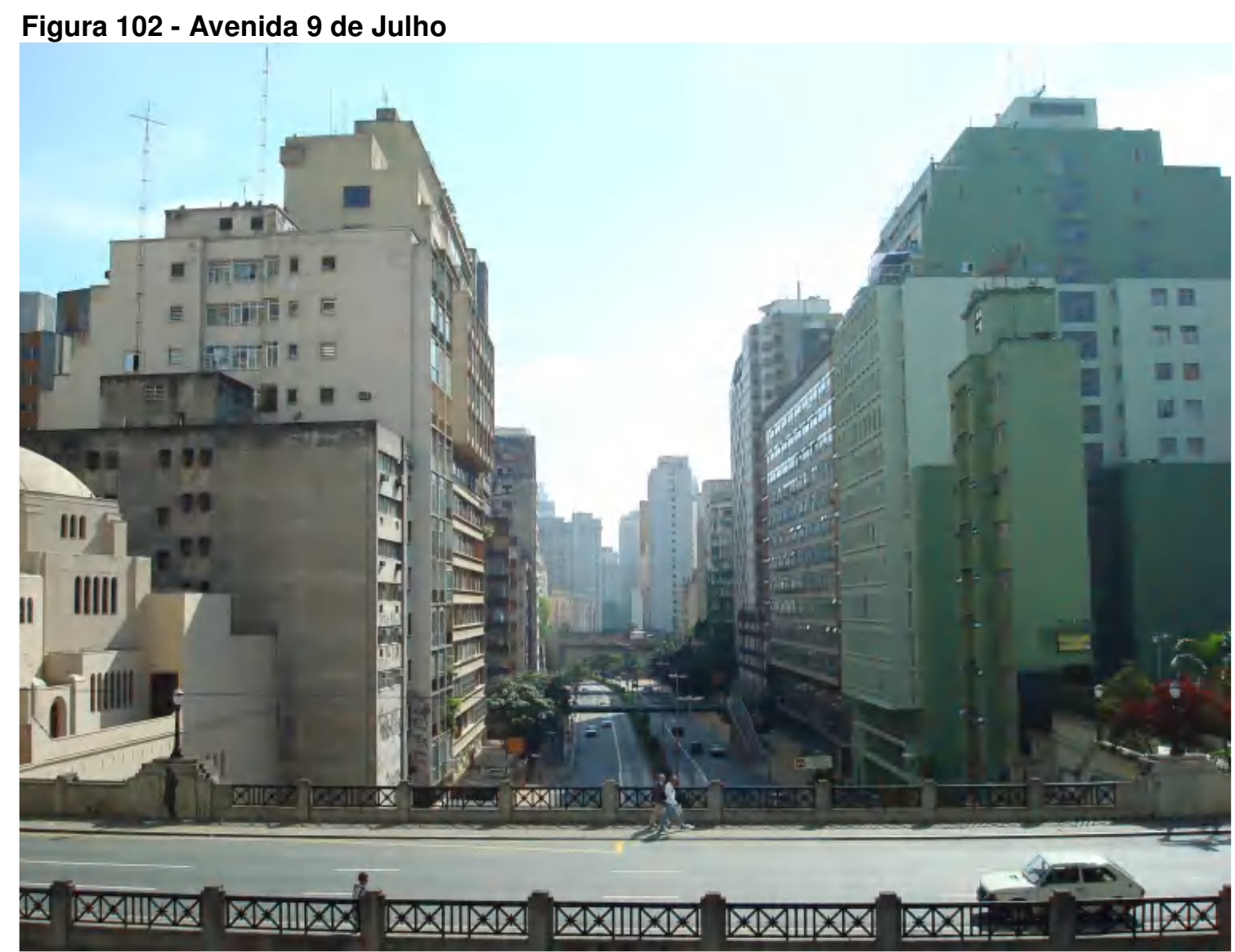

FREITAS, R. [sem título], 2008. Formato JPEG

Têm-se acima edificações à Avenida 9 de Julho, cujo conjunto reflete a aplicação do Decreto-Lei no 75 de 1941, que estabelecia altura mínima de 29m para construções neste trecho da via. Vê-se o escalonamento lateral das edificações a partir dos 29 metros de altura (2,5 metros) e a partir dos 45 metros (4,5 metros de recuo lateral). Frontalmente, evidencia-se o recuo de 1 metro para cada 3 metros em altura, a partir dos 45 metros de altura do edifício. À esquerda da foto, vê-se que na empena cega do edifício junto ao templo religioso foram abertas pequenas janelas, que perderiam sua função caso o templo fosse elevado em altura. Estas janelas foram abertas ilegalmente. Nota-se que a escala das edificações nesta avenida é diferente daquelas vistas anteriormente. Supõe-se por esta imagem que tenha-se utilizado o critério previsto no Decreto-Lei no 75/41, de edificação única sobre vários lotes, independente de seus formatos em planta. Nota-se que este critério gerou edificações em escalas mais apropriadas às funções que exercem e à escala desta via, possivelmente frutos de investimentos de vários proprietários, apesar de ainda serem edificadas com a premissa de contigüidade lateral até os 29 metros de altura. Vale ressaltar que este critério de edificação única em vários lotes já havia sido previsto para a Avenida Ipiranga, porém, aqui sua aplicação é mais evidente. 


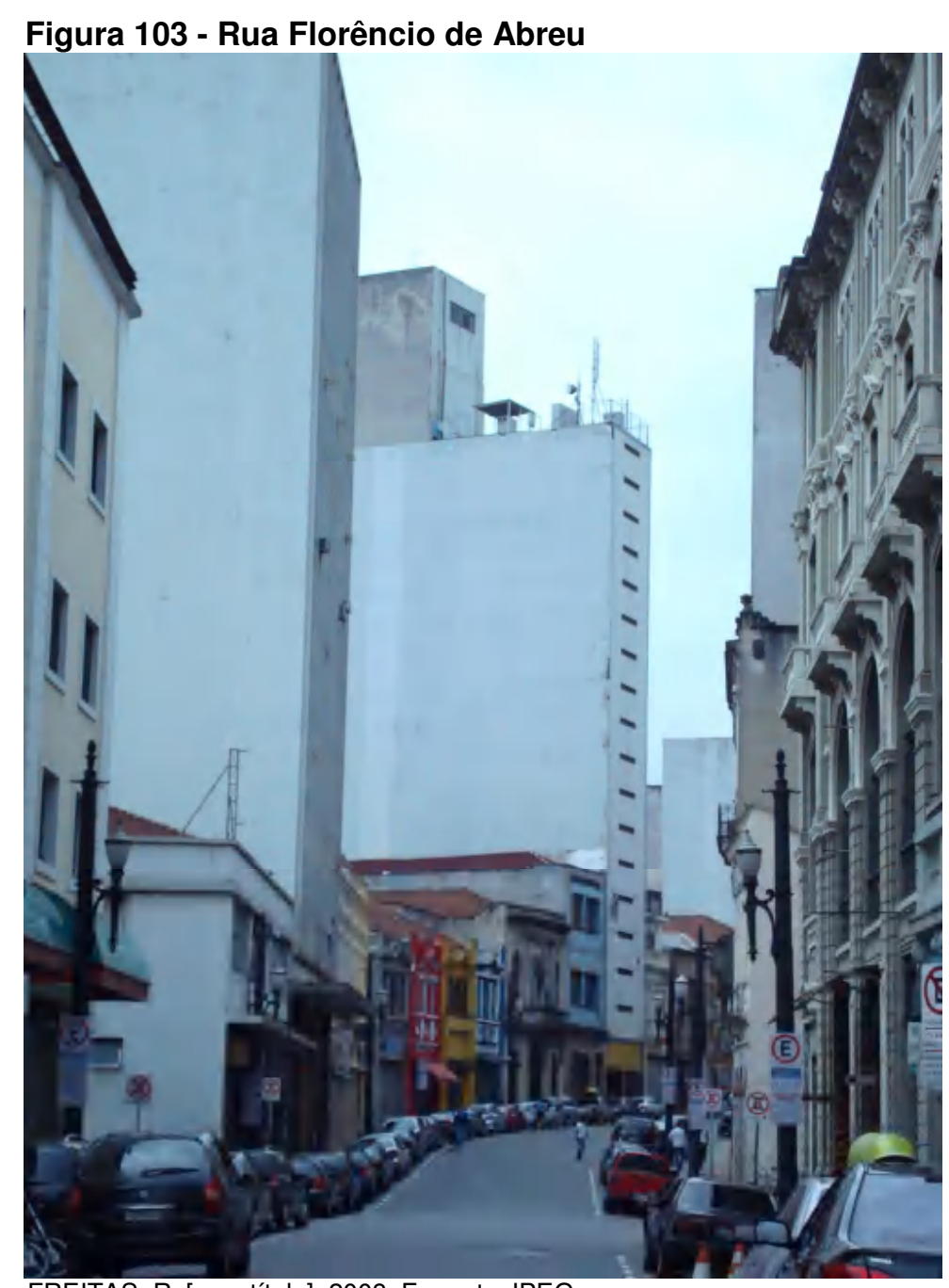

FREITAS, R. [sem título], 2008. Formato JPEG

Supõe-se pela imagem acima que o edifício com térreo mais 17 pavimentos tenha sido edificado após a criação do Decreto-lei no 92, de 1941, que permitia a construção, sem escalonamento, de 3 vezes a largura da via quando esta fosse maior ou igual a 18 metros. Entende-se que este edifício foi construído antes da Lei no 5261, de 1957, que estabeleceu coeficiente de aproveitamento máximo de 6 vezes a área do terreno para edificações comerciais. Porém, pode-se ainda supor que se este edifício for um prédio de estacionamento, talvez tenha sido construído após a Lei n 6877, de 1966, que definiu coeficiente de aproveitamento 15 para edifícios garagem, de acordo com projeto de lei enviado por Prestes Maia à Câmara dos Vereadores em 1965. Vê-se à esquerda da foto acima que as construções assobradadas são remanescentes do início do século XX e que à direita há um edifício com térreo mais quatro pavimentos, cuja fachada se adequa aos critérios legais previstos pela Lei nº 2332, de 1920, o padrão municipal de fachadas. 
Figura 104 - Rua Conselheiro Nébias

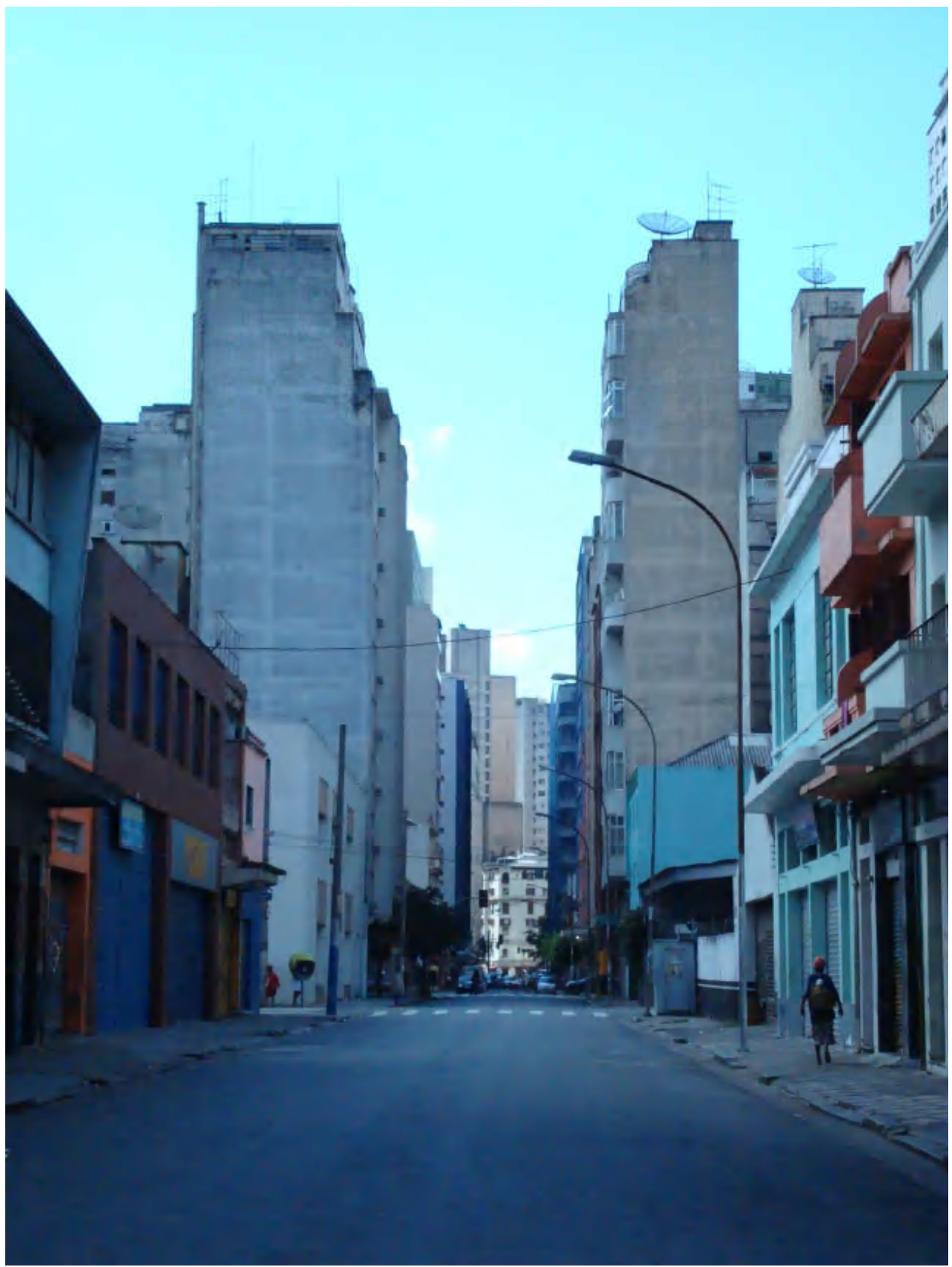

FREITAS, R. [sem título], 2008. Formato JPEG

No "centro" da cidade não faltam exemplos, como a imagem acima, para representar a paisagem urbana resultante do escalonamento das edificações previsto em lei a partir da década de 1930. Ao lado, evidencia-se a presença marcante da aplicação destes critérios em visuais urbanas resultantes da regulamentação do lote com base em taxas de ocupação próximas a $100 \%$ da área do terreno e coeficientes de aproveitamento superiores a 10 vezes o lote.

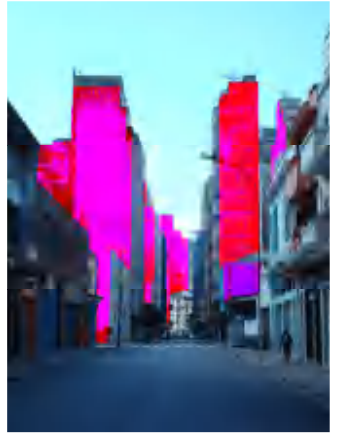

FREITAS, R. [sem título], 2008. Formato JPEG 
Figura 105 - Planta do centro de São Paulo, 1952/57 - leis de 1972
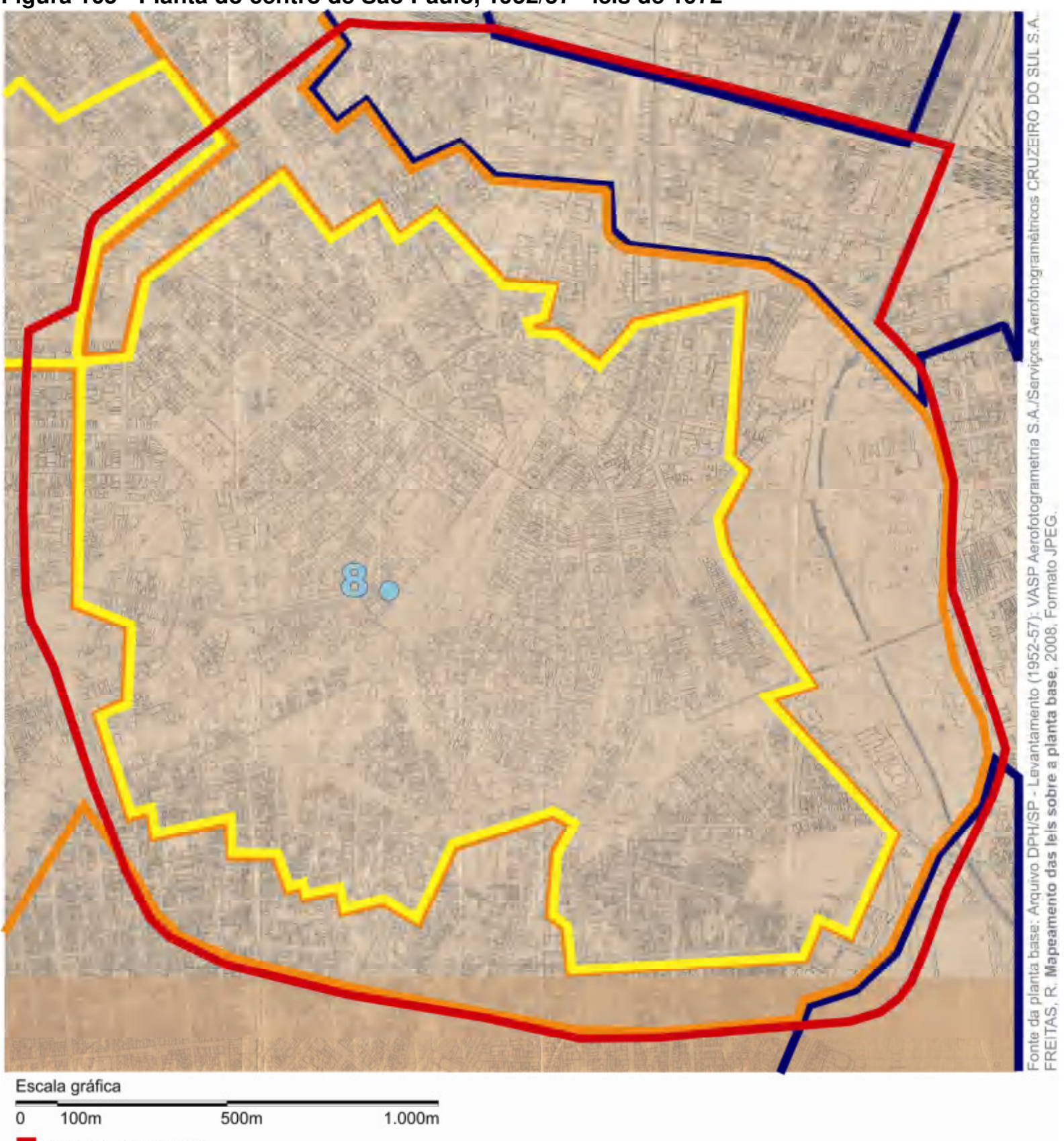

- Perímetro de Estudo

1972 - Lei n 7.805 / Z5

-8 1989 - Edificio à Rua Formosa, 75 - vide Anexo 1

1972 - Lei $n^{\circ} 7.805$ / Z3

1972 - Lei n 7.805 / Z2 
Lei de 1972 mapeada na página anterior sobre planta do centro de São Paulo de 1952/57:

\section{Lei 7.805 (1972)}

- criou as zonas Z1 a Z6 e Z8, para as quais foram definidas as seguintes variáveis de ocupação do solo: frente mínima; área mínima; recuos mínimos; taxa de ocupação máxima; coeficiente aproveitamento; limite de altura; recuos especiais (e vias de melhoramentos); vagas de estacionamento de veículos e pátio de manobra para carga e descarga; número máximo de pavimentos; e profundidade do corredor de uso especial.

- promulgada após uma anistia de edificações irregulares;

- adotou, na medida do possível a Carta de Atenas (C.I.A.M. - novembro/1933) tentando segregar duas das quatro funções consideradas básicas (habitar e trabalhar);

- possuía quatro tipos de zonas residenciais (estritamente residencial de baixa densidade populacional - os bairros jardim; predominantemente residencial de baixa, média e alta densidade); dois tipos de zona industrial (predominantemente e exclusivamente industrial); um tipo de zona predominantemente comercial e de prestação de serviços; zonas especiais, onde se encontra incluída até a zona rural, que seria um objeto de planos e projetos específicos;

A área delimitada nesta pesquisa pertencia às seguintes zonas:

- Z2 - uso predominantemente residencial, com T.O. $<0,5$ e C.A. $<1$;

- Z3 - uso predominantemente residencial, com T.O. $<0,5$ e C.A. $<2$;

- Z5 - uso misto, com T.O. <0,8 e C.A. <3,5; 
Figura 106 - Avenida Radial Leste-Oeste, Viaduto Júlio de Mesquita Filho

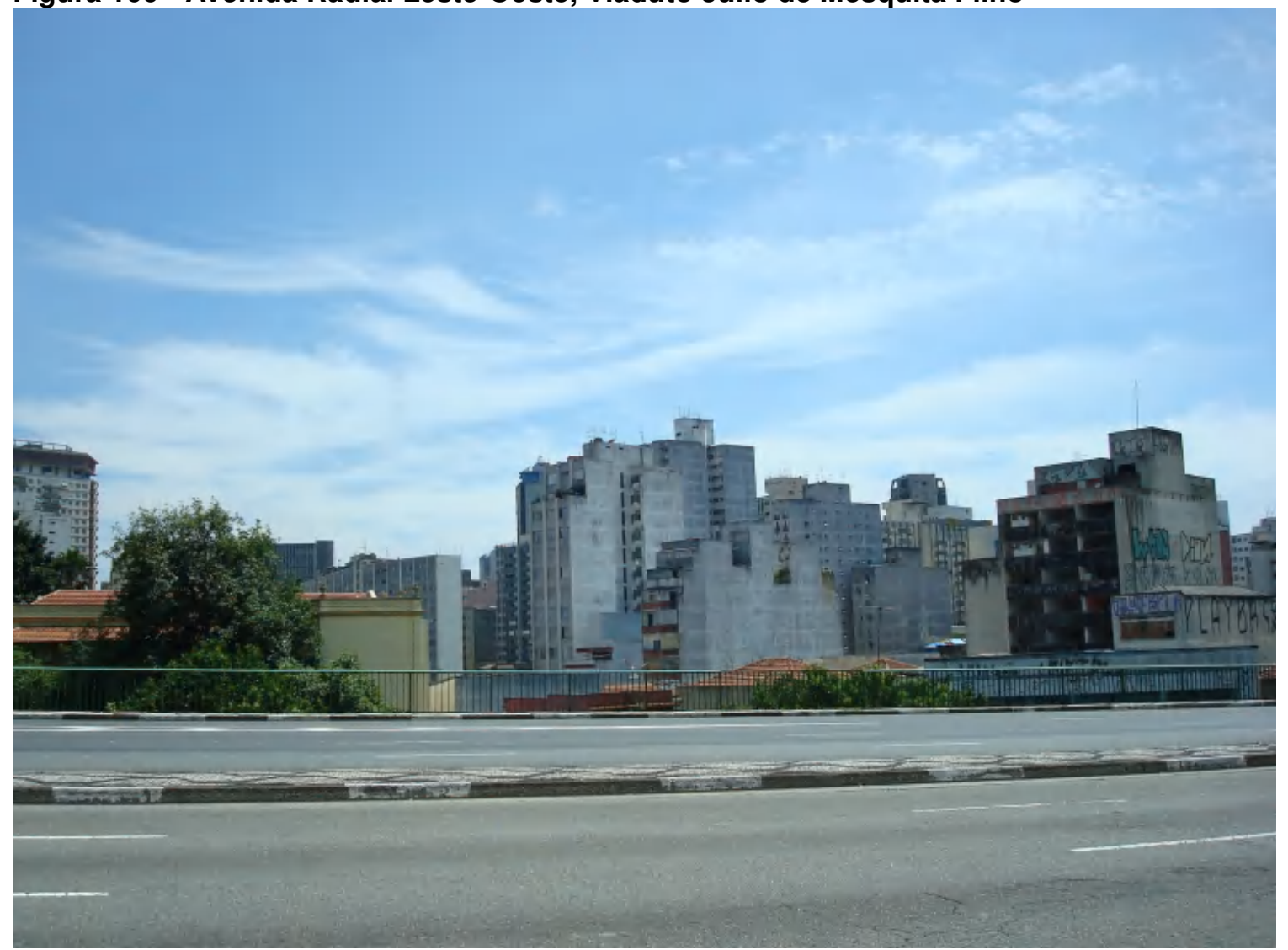

FREITAS, R. [sem título], 2008. Formato JPEG

Acima, vê-se a área interna ao perímetro de estudo desta pesquisa. Percebe-se pela imagem abaixo que os avanços urbanísticos presentes na Lei ํo 7.805 de 1972 pouco influíram na reconstrução da paisagem urbana do "centro", resultado do uso dos lotes criados no século XIX, edificados ao longo do século XX com elevadas taxas de ocupação, configurando um grande conjunto de paredes cegas, sem função de ventilação ou iluminação dos ambientes internos às construções.

Figura 107 - Avenida Radial Leste-Oeste

Viaduto Júlio de Mesquita Filho

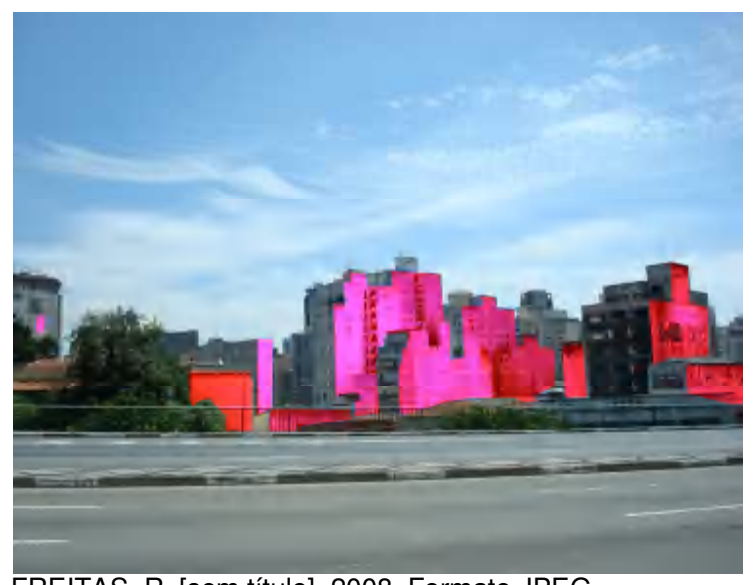

FREITAS, R. [sem título], 2008. Formato JPEG 


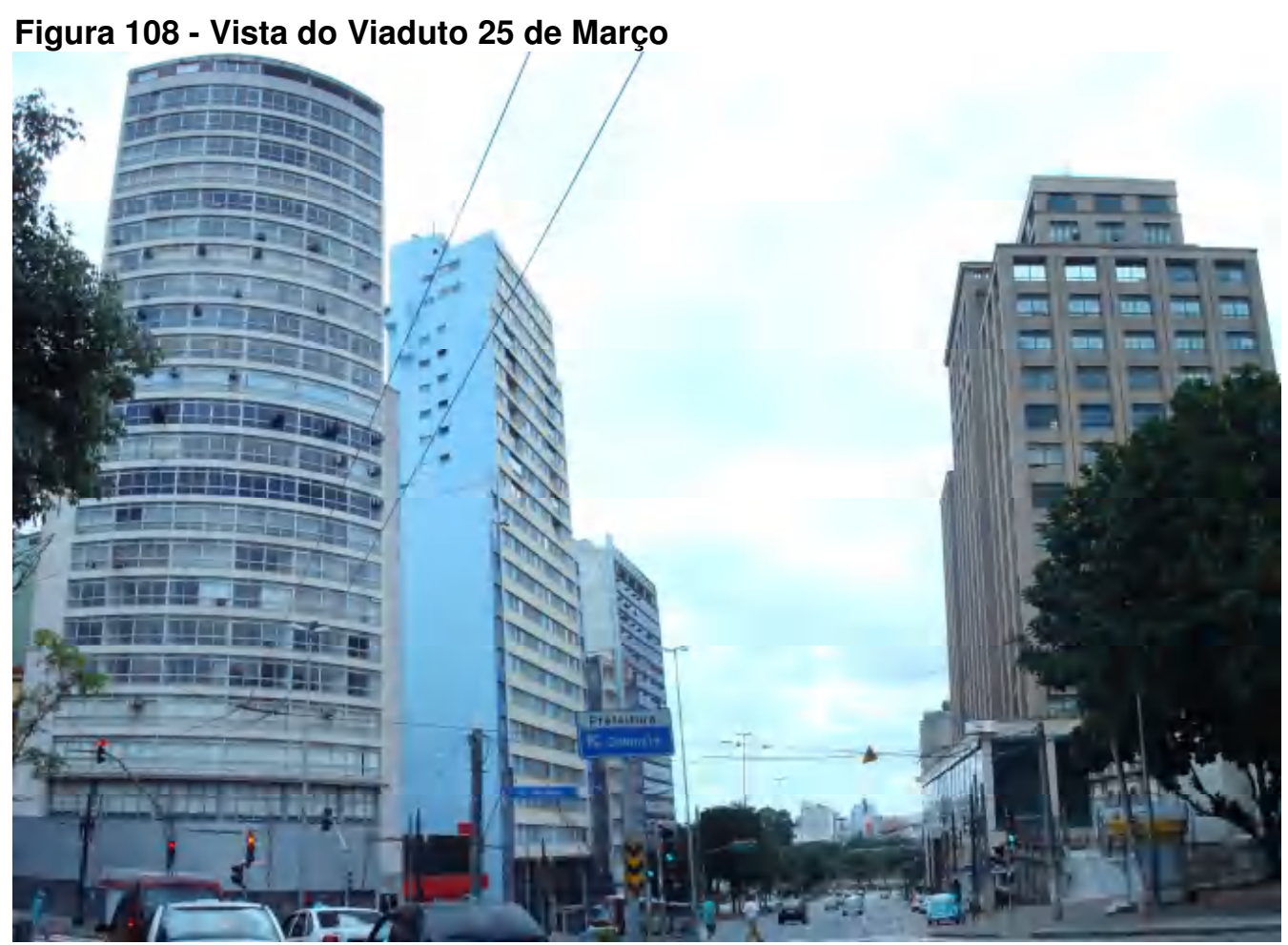

FREITAS, R. [sem título], 2008. Formato JPEG

Dificilmente lotes como o retratado acima, entre a construção de esquina, à esquerda, e o grande edifício azul, mais ao centro da imagem, terão suas construções recaracterizadas. A imagem abaixo reflete a volumetria urbana que teria resultado da aplicação do Decreto-lei no 92 de 1941, antes de 1957, quando limitouse o coeficiente de aproveitamento para edifícios comerciais em seis vezes a área do lote. Supõe-se que após 1972, inviabilizou-se a planta de uma possível edificação para este lote, que deveria ter 3 metros de recuos laterais a partir do segundo pavimento, taxa de ocupação máxima do lote de $80 \%$ de sua área e coeficiente de aproveitamento máximo de 3,5 vezes a área do terreno.

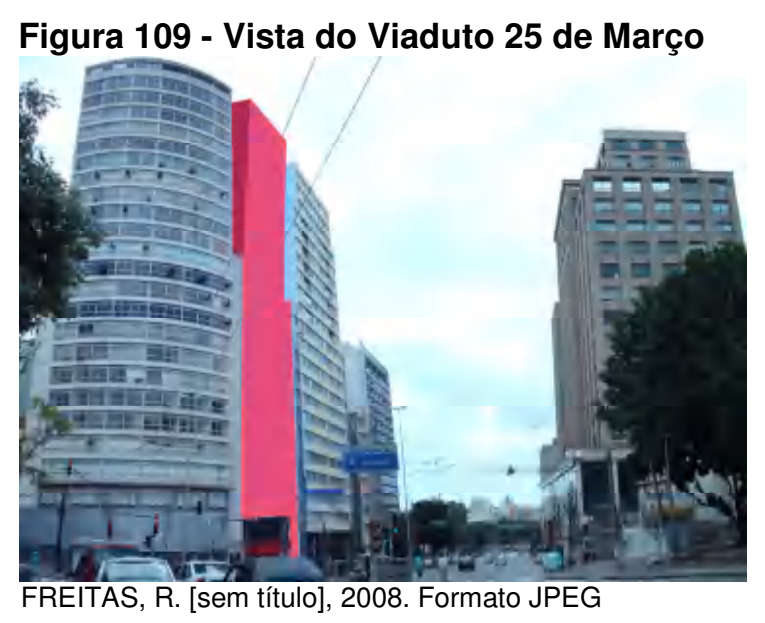


Figura 110 - Rua Senador Feijó

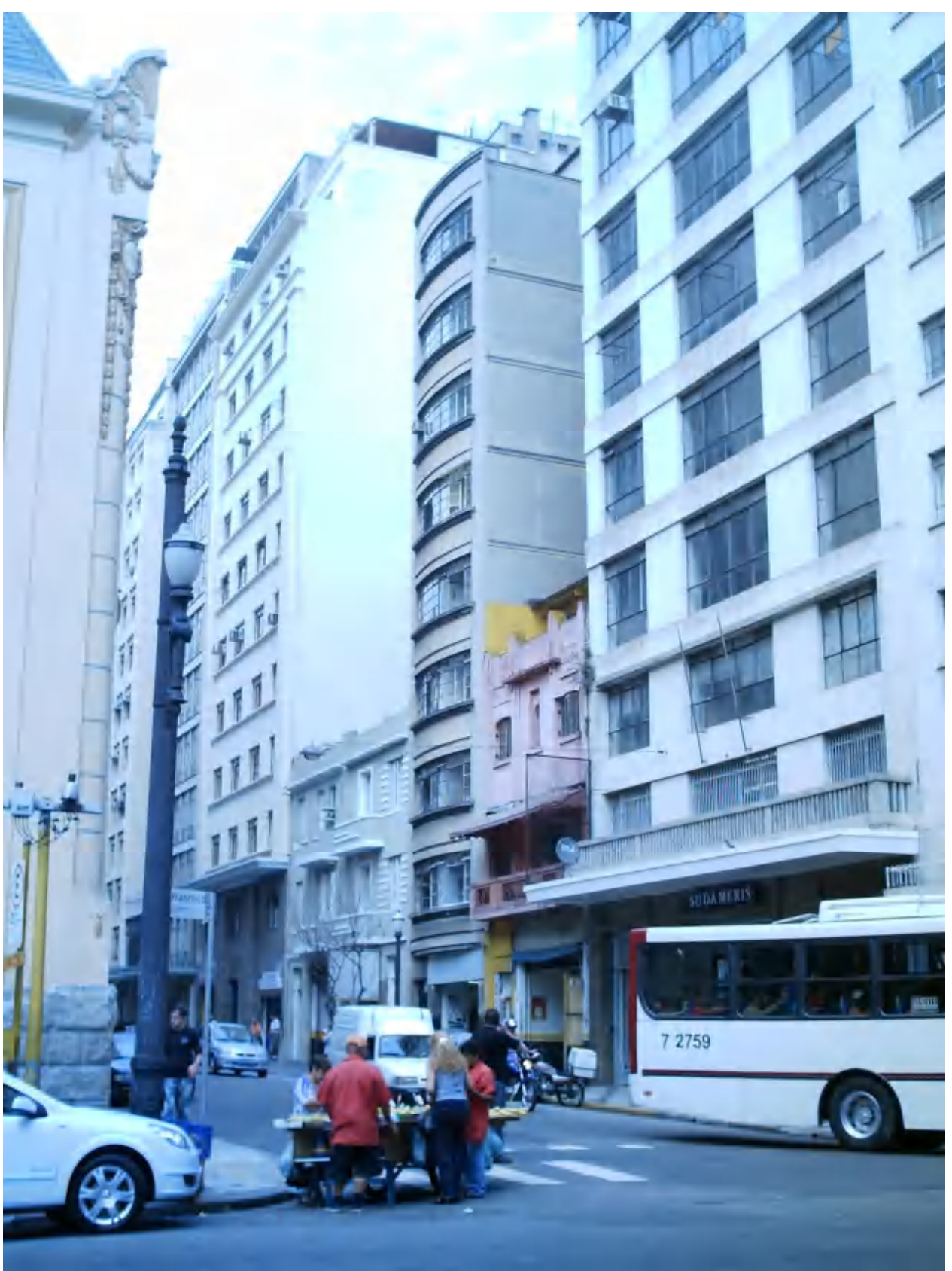

FREITAS, R. [sem título], 2008. Formato JPEG

Pode-se aplicar a análise da página anterior aos dois lotes retratados acima, que não chegarão a compor a paisagem prevista pela legislação urbana da década de 1940 - conforme ilustração ao lado - inviabilizada a partir de 1957 e definitivamente cristalizada com os novos critérios legais de 1972.

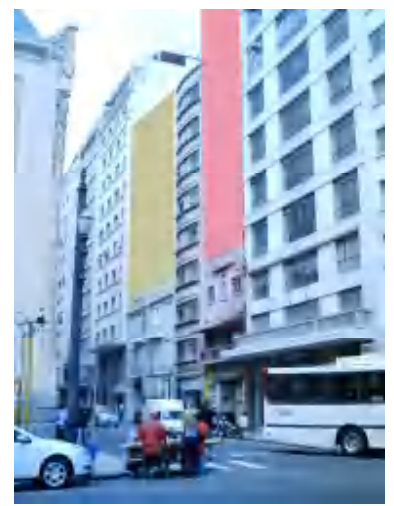

FREITAS, R. [sem título], 2008. Formato JPEG 
Figura 111 - Planta do centro de São Paulo,1974 - leis de 1991 a 1997
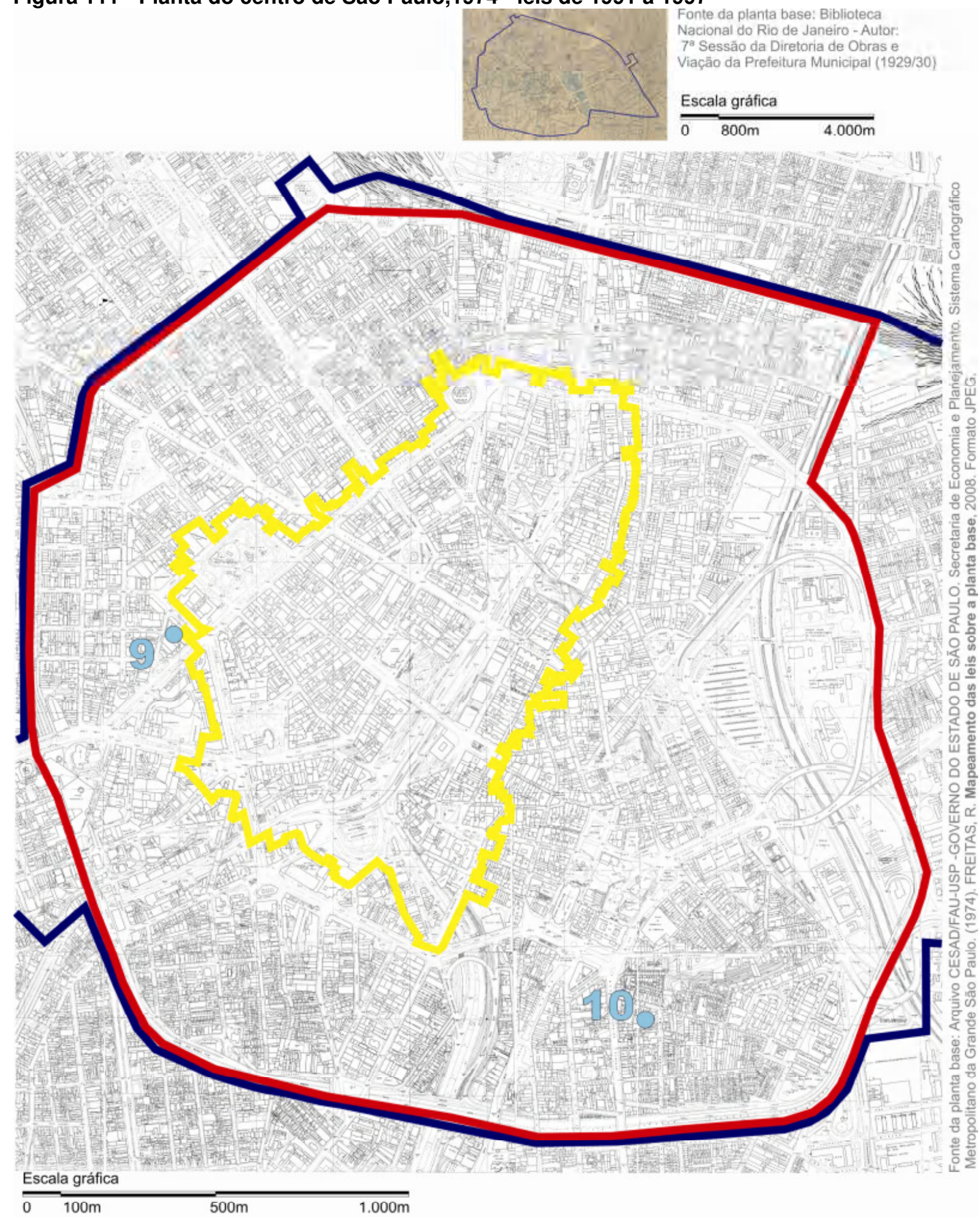

Perimetro de Estudo 
Leis de 1991 a 1997 mapeadas na página anterior sobre planta do centro de São Paulo de 1974:

Lei 11.090 (1991) - Operação Urbana Anhangabaú:

- instrumento jurídico de desregulamentação da Lei 7.805/72 em São Paulo;

- forma legal de alteração dos critérios que regulamentam a cidade, em troca do financiamento de benefícios para a região do Vale do Anhangabaú com a receita da venda de potencial construtivo e outras características urbanísticas para empreendimentos imobiliários neste perímetro.

- controle do adensamento com um estoque de potencial construtivo de $150.000 \mathrm{~m} 2$, considerado compatível com a infra-estrutura, equipamentos e serviços públicos existentes.

Lei no 12.349 (1997) - Operação Urbana Centro, diretrizes:

- abertura de praças e de passagens para pedestres no interior das quadras;

- estímulo ao remembramento de lotes e à interligação de quadras mediante o uso dos espaços aéreo e subterrâneo dos logradouros públicos;

- disciplina do espaço destinado ao transporte individual e a adequação dos espaços destinados ao transporte coletivo;

- incentivo à não impermeabilização do solo e à arborização das áreas não ocupadas; e

- conservação e restauro dos edifícios de interesse histórico, arquitetônico e ambiental, mediante instrumentos apropriados;

- composição das faces das quadras, de modo a valorizar os imóveis de interesse arquitetônico e a promover a harmonização do desenho urbano;

- adequação, aos objetivos desta lei, do mobiliário urbano existente e proposto;

- incentivo à construção de habitações e garagens;

- incentivo à recuperação e reciclagem de próprios públicos existentes na área central;

- criação de condições para a implantação de ruas ou regiões comerciais com regime de funcionamento de 24 (vinte e quatro) horas por dia;

- desestímulo à permanência e a proibição de instalação de novos estabelecimentos de comércio atacadista de cereais, de madeiras e de frutas na área da Operação Urbana; 


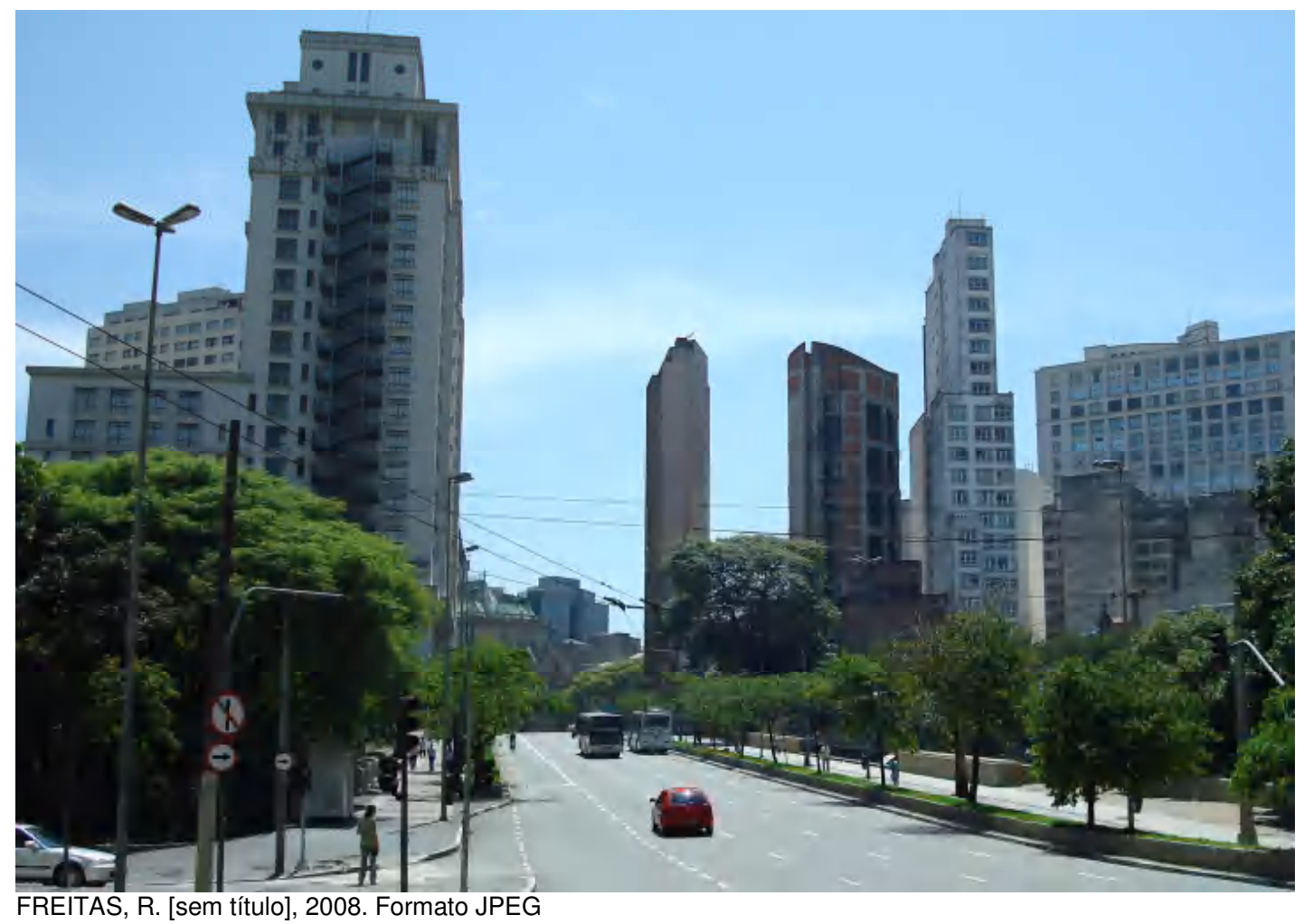

A partir de 1983, critérios específicos de combate a incêndio levaram à adaptação de edifícios construídos com rotas de emergência insuficientes para sua evacuação em caso de incêndio. Deste modo, vê-se à esquerda da imagem acima um edifício que foi adaptado após sua construção, com uma escada de emergência externa. Este tipo de adaptação foi a única caracterização da paisagem urbana do "centro", verificada nesta pesquisa, como reflexo da aplicação das normas de combate a incêndio.

A imagem acima retrata edificações construídas com grandes coeficientes de aproveitamento do solo, possivelmente antes de 1957. Ao centro desta imagem vêse um edifício com mais de 15 andares, cujo formato em planta segue exatamente os limites do terreno, resultando em taxa de ocupação próxima de $100 \%$ do lote, considerando-se a existência de um poço interno de ventilação. Esta maneira de apropriação do solo urbano foi permitida pela legislação, quanto à altura, até 1957 e, quanto à taxa de ocupação, até 1972. A partir de então, os novos critérios legais impediram que lotes lindeiros a estes já densamente ocupados fossem utilizados da mesma maneira, resultando na paisagem urbana que se vê acima e nas fotos da próxima página. 
Figura 113 - Rua Antonio de Godói, com Largo do Paissandu

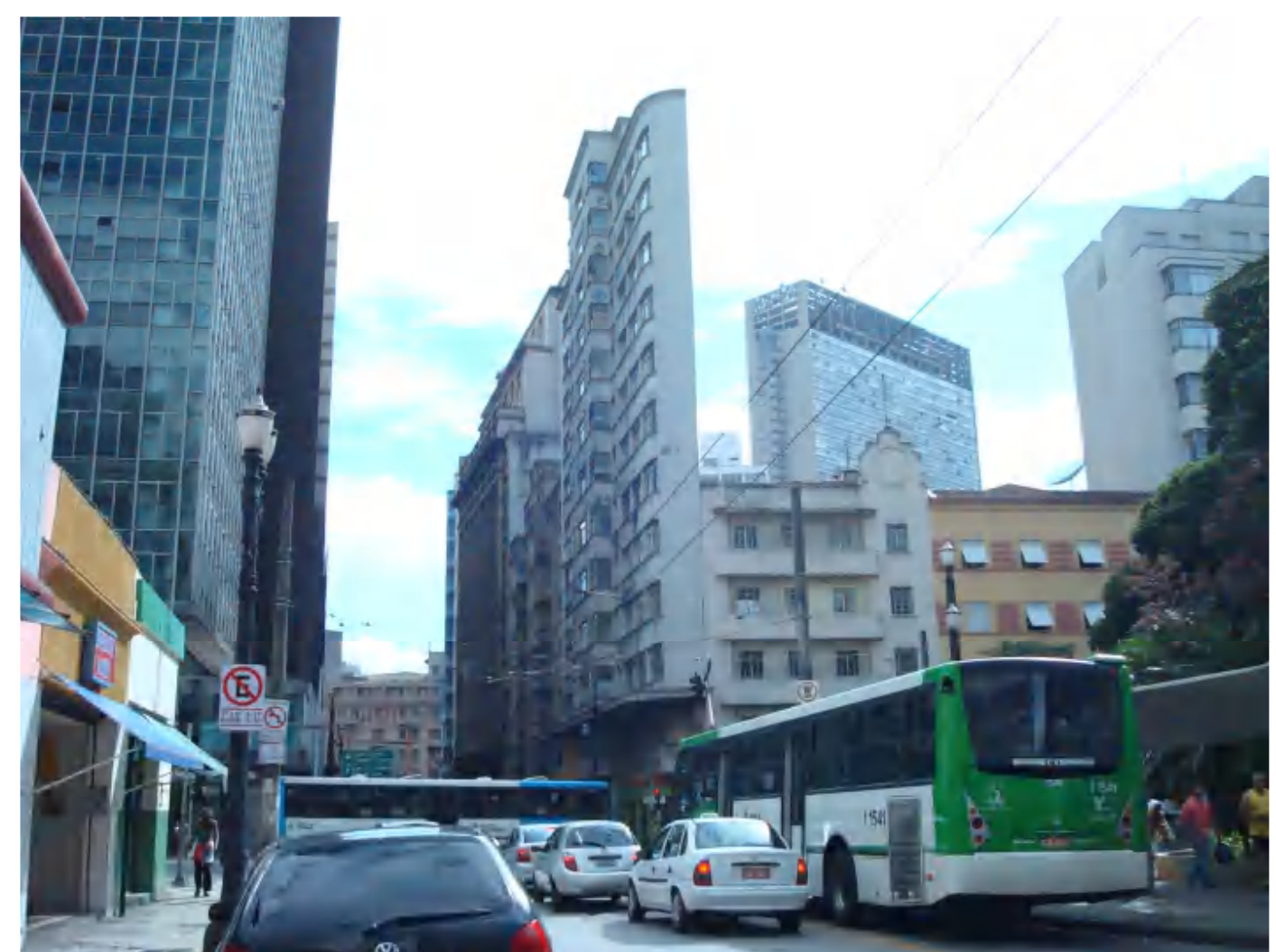

FREITAS, R. [sem título], 2008. Formato JPEG

Figura 114 - Rua 25 de Março

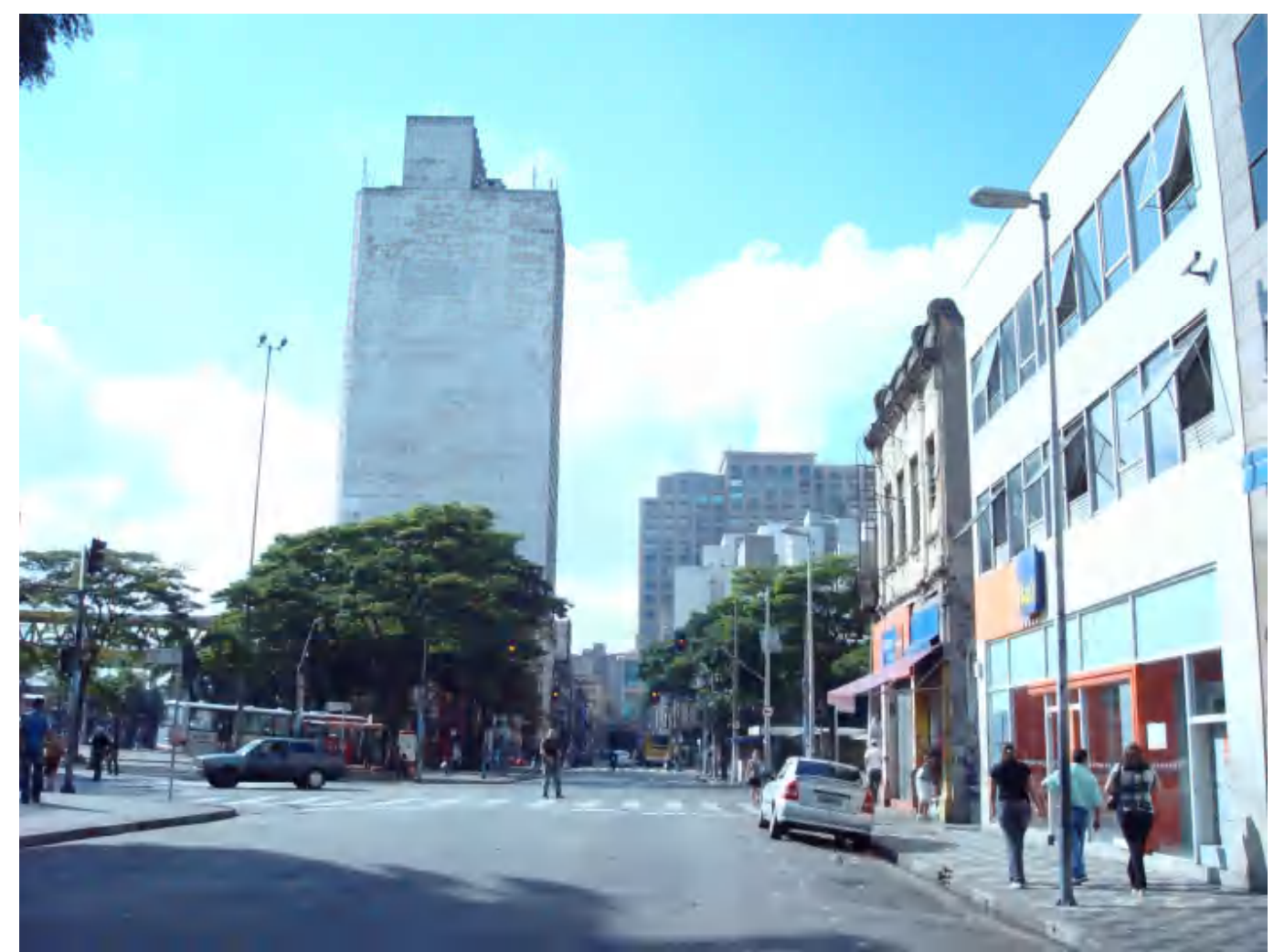

FREITAS, R. [sem título], 2008. Formato JPEG 
Figura 115 - Praça Doutor João Mendes com Rua Riachuelo

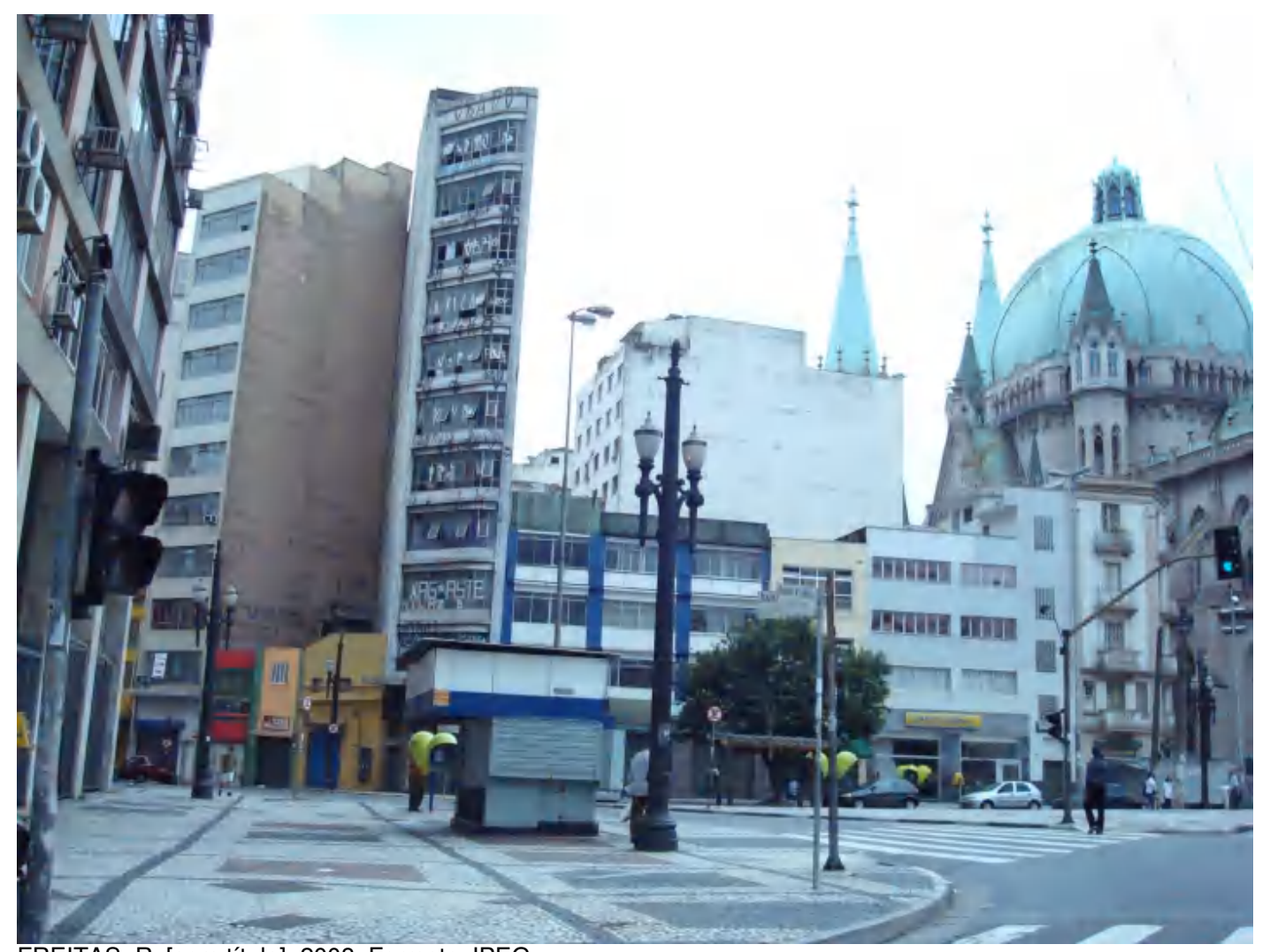

FREITAS, R. [sem título], 2008. Formato JPEG

Figura 116 - 1893 - Trecho da região central de São Paulo

(evidenciando local da atual Praça Doutor João Mendes com Rua Riachuelo)

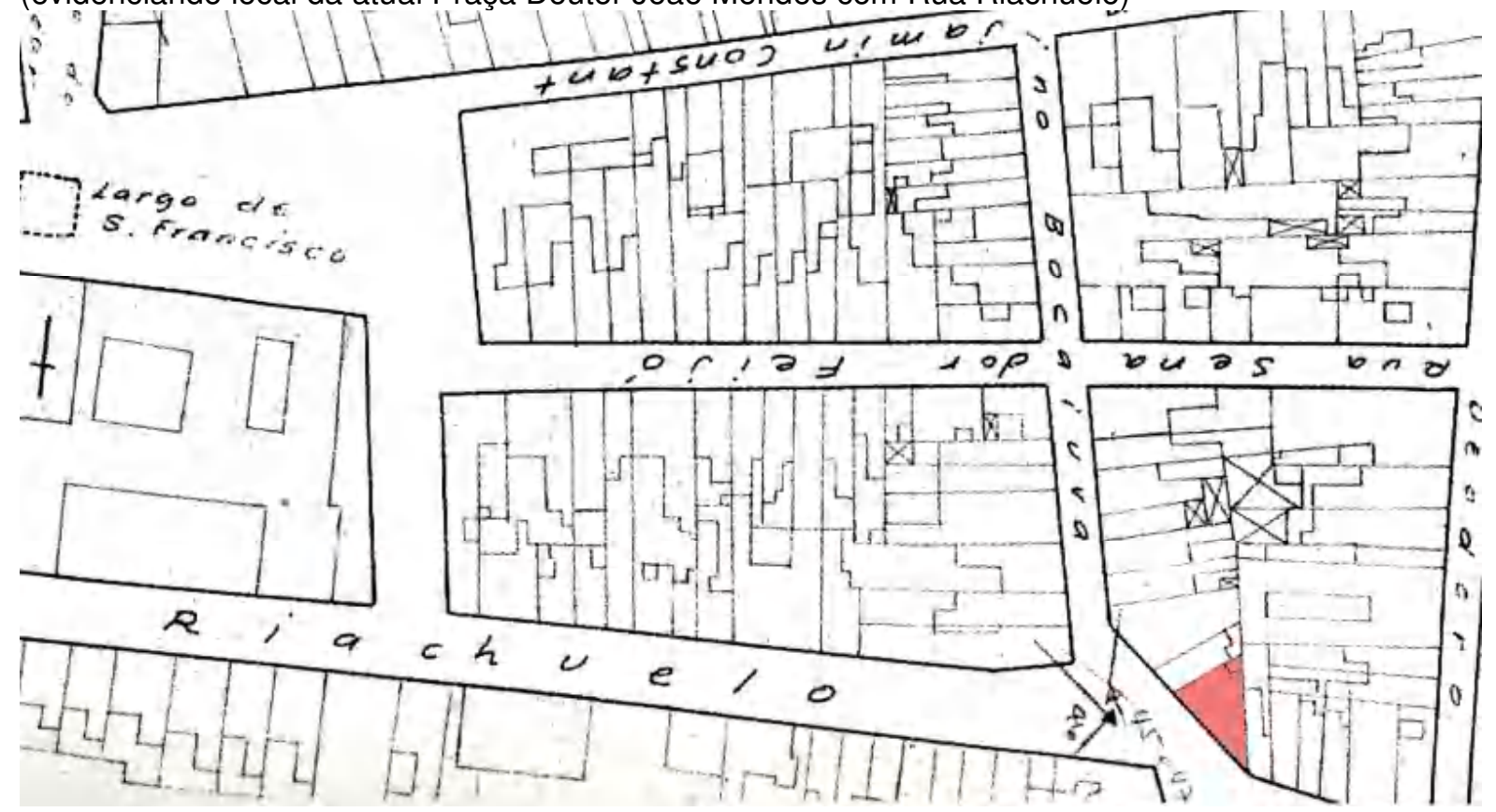

Planta da área central da cidade de São Paulo - levantada pelo engenheiro V. Huet de Bacellar em 1893. in: TOLEDO, Prestes Maia e as origens do urbanismo moderno em São Paulo. São Paulo, Empresa das Artes, 1996, p.68. 
Os retratos expostos neste capítulo e a fotografia da página anterior, com a planta correspondente aos lotes em 1893, ilustram a paisagem urbana característica do "centro" de São Paulo hoje, em 2008. Poucas alterações da volumetria urbana são verificadas em função da aplicação da Lei no 11.090 de 1991, Operação Urbana Anhangabaú, extinta três anos após sua criação, e da Lei no 12.349 de 1997, Operação Urbana Centro, ainda em vigor.

$\mathrm{Na}$ foto da página anterior vê-se, à esquerda, um peculiar conjunto de três edificações na esquina da Rua Riachuelo com a Praça Doutor João Mendes, cujos lotes formam um triângulo, evidenciado em vermelho na planta de 1893, antes de ter sido subdividido em três partes. Vê-se ainda que nos lotes lindeiros a este triângulo construíram-se dois edifícios com mais de 10 pavimentos, de acordo com as regulamentações urbanas do século XX, provavelmente antes de 1957 - tendo em vista a taxa de ocupação do terreno próxima a $100 \%$ e seu coeficiente de aproveitamento superior a dez vezes sua área. Entende-se que de acordo com os critérios legais vigentes hoje em dia, os três lotes de esquina estão cristalizados. Ou seja, a paisagem urbana neste trecho da cidade possivelmente não será alterada. Pois, mesmo que fossem reagrupados os três lotes de esquina, não seria possível erguer um edifício no lote triangular resultante, com o mesmo porte dos edifícios lindeiros. Este fato não agrega valor a estes lotes, cujo perímetro externo já estava definido no século XIX e de lá para cá deixaram de ser um único lote triangular de pequenas dimensões para se tornarem três lotes ainda menores, hoje fadados a abrigar as três construções vistas na página anterior, ladeadas por duas empenas cegas de mais de dez pavimentos.

Na página anterior está ilustrado um dos mais expressivos exemplos da contradição criada no "centro" da cidade a partir da manutenção, na regulamentação do lote urbano, de critérios das Ordenações Afonsinas, Manuelinas e Filipinas, baseadas na Constituição Zenoniana. Critérios estes, presentes nas leis urbanas paulistanas até 1972, fundamentados em elevadas taxas de ocupação de pequenos lotes (do século $X I X)$. 


\section{6- CONCLUSÃO}

A partir das informações dos capítulos anteriores e das análises expostas no anexo 1, conclui-se que a legislação urbana paulistana caracterizou a paisagem urbana dos atuais distritos Sé e República, considerados neste trabalho como "centro" de São Paulo. Verificou-se ainda que, em um momento específico da história de São Paulo, houve um movimento inverso, em 1929 a legislação urbana foi revisada em função de obras construídas em desacordo com a lei vigente quando de sua construção.

Entende-se neste trabalho que a paisagem urbana é formada principalmente por edifícios privados, considerados como fluxos urbanos, organizados por estruturas que os precedem. Assim, entende-se que a paisagem do "centro" é o reflexo de suas estruturas urbanas físicas (lotes) e não-físicas (leis).

Constatou-se que durante o século passado foram construídos edifícios privados no "centro" a partir de uma contradição entre as estruturas físicas e não-físicas, quanto às suas fundamentações conceituais. Verificou-se também que a cristalização da paisagem do "centro" ocorreu em função da sobreposição e substituição de critérios urbanísticos durante a criação das leis urbanas paulistanas no século XX.

Nos atuais distritos Sé e República ter-se-ia quase a mesma configuração viária de fins do período imperial, com os respectivos lotes, se não fossem as intervenções viárias, contidas principalmente no Plano de Avenidas. Porém, se parte das vias mudaram em função destas intervenções, a grande maioria delas, principalmente no núcleo histórico, segue com o mesmo traçado de 1800, com alargamentos em alguns trechos e com alguns viadutos construídos no século XX. Sendo assim, evidenciou-se que as estruturas físicas (lotes) de grande parcela do "centro" foram configuradas no século XIX, como se viu a partir da planta de 1893 levantada por V. Huet de Bacellar, exposta no capitulo 2 e em um trecho ampliado no capítulo 5. Pode-se dizer que as estruturas conceituais pelas quais estes lotes foram organizados, remontam ao século XIX, quando critérios das Ordenações Filipinas 
ainda estavam presentes, quando as questões urbanas eram encaminhadas por jurisconsultos e não por urbanistas, visto que estes últimos não existiam enquanto profissionais. Mesmo os lotes criados até 1920, no "centro", foram delineados sob critérios do século XIX, pois as leis que introduziram os primeiros critérios de lotes mínimos em São Paulo surgiram a partir da década de 1920. Entende-se que os lotes do perímetro estudado neste trabalho surgiram sem a aplicação dos conceitos urbanísticos amadurecidos durante o século XX.

Analisando-se as estruturas não-físicas, isto é, as leis urbanas, pode-se dizer que no início do século XX eram apenas leis edilícias, enfocando principalmente as questões ligadas aos edifícios, sendo que paulatinamente durante o século $\mathrm{XX}$ foram introduzidos conceitos urbanísticos a tais leis, consolidando-se tais conceitos em 1972, com a legislação de parcelamento, uso e ocupação do solo.

Ainda tratando-se especificamente das estruturas não-físicas, pode-se dizer que a partir de 1929, com a Lei no 3.427/29, houve uma mudança de critérios legais a partir de obras construídas sob novos paradigmas, não presentes nas regras urbanas vigentes até a década de 1920. Verificou-se que as estruturas urbanas não-físicas (leis) foram alteradas após a construção dos edifícios Sampaio Moreira (1924) e Martinelli (1929), aprovados pela prefeitura em desacordo com a legislação vigente àquela data. A partir de então, as leis vigentes até aquele momento perderam sua eficácia, sendo substituídas pelas regras desta Lei n우 3.427/29, que manteve em seu texto dois conceitos antagônicos. O primeiro, resultante da busca de homogeneização da paisagem urbana, com base na escola européia, tendo como referência a paisagem urbana parisiense, conceito presente na legislação desde 1886, com o padrão municipal de fachadas e suas linhas mestras arquitetônicas horizontais, em edificações contíguas lateralmente. O segundo conceito, antagônico ao primeiro, foi referenciado na paisagem urbana norte-americana, quanto à regulamentação de arranha-céus. A partir de 1934, com o Ato no 663/34 (consolidação das leis de 1929 a 1934), este segundo conceito foi reforçado pelo critério de escalonamento das edificações em busca de garantir a penetração dos raios solares no espaço urbano. Deste modo, as leis urbanas, foram estabelecidas a partir de conceitos edilícios do século XIX e de conceitos urbanísticos do século XX, aplicados concomitantemente a partir de 1929. 
Portanto, conclui-se que a paisagem urbana do centro de São Paulo foi caracterizada pela associação de estruturas físicas (lotes) do século XIX a estruturas não-físicas (leis), que continham conceitos antagônicos em seus textos, a partir de 1929, pois associavam os critérios edilícios do século XIX aos conceitos urbanísticos e edilícios do século $X X$.

Supõe-se que não apenas as leis tenham configurado as obras dos lotes privados. Porém, como não se estudaram nesta pesquisa as demais possíveis variáveis que teriam também caracterizado o "centro" - por exemplo, o processo de projeto, a bagagem intelectual dos responsáveis por sua construção, as regras de mercado, entre outros - o foco deste trabalho manteve-se na regulamentação oficial de construções no perímetro central da cidade de São Paulo.

Tendo-se percorrido o caminho de pesquisa detalhado nos capítulos anteriores, complementado por informações apresentadas mais adiante nos anexos, pode-se afirmar que a legislação urbana paulistana do século XX representou os anseios dos indivíduos e grupos ligados à atividade da construção civil nesta cidade. Pode-se afirmar que o "centro" paulistano é o retrato de um período vivido por tais indivíduos inseridos em seus incontáveis grupos, que conquistaram nesta área de São Paulo a convivência em um modo de vida urbana com mais salubridade e maior aproveitamento do terreno, comparando-se à realidade do século XIX nesta mesma área.

No entanto, entende-se que a paisagem do "centro" da cidade, estruturada por lotes do século XIX e leis urbanas do século XX é um fluxo urbano que está no fim. Pois atualmente está cristalizada e não continuará sendo construída a partir das mesmas estruturas que a caracterizaram no século passado, visto que as construções dos lotes privados não sofreram alterações significativas nos últimos 36 anos. Pode-se dizer que as imagens expostas no capítulo anterior representam a paisagem urbana do "centro", conforme estruturada ao longo do século XX, com transformações consideravelmente reduzidas a partir de 1957 e praticamente estagnadas a partir de 1972. Vê-se que está por vir um processo de reconfiguração da paisagem urbana do "centro", principalmente quando se considera o histórico desta cidade, que se reconstruiu (sobre si mesma) duas vezes - substituindo primeiro a taipa pelo tijolo e 
depois o tijolo pelo concreto armado.

Nos atuais distritos Sé e República vêem-se os arranha-céus que ocuparam lotes até 1957 com altos coeficientes de aproveitamento, chegando a 25 vezes a área destes terrenos, em projeções de aproximadamente $100 \%$ de suas áreas. Vêem-se prédios construídos sob os critérios de contigüidade lateral entre edifícios até 1972, resultando, portanto, em grandes empenas cegas laterais, sem função de iluminar ou ventilar tais edificações, ou seja, apenas com a função de divisa entre lotes. Como se fossem muros, estas paredes cegas separam duas propriedades, porém, enquanto muros que têm em geral 39 metros de altura, referência de gabarito mínimo compulsório estabelecido pela legislação para edificações privadas, em diversas vias do "centro", até 1957. Entende-se que este fluxo urbano está praticamente estagnado há quase 40 anos, principalmente em função da Lei $n^{\circ}$ 7.805, de 1972, e que dará lugar a um novo fluxo, uma nova paisagem urbana, em função da Lei $n^{\circ}$ 12.349, de 1997.

A Lei $n^{0} 7.805 / 72$ inviabilizou o uso de lotes pequenos ou muito irregulares criados no século XIX. Exigiu que as novas construções tivessem recuos laterais de 3 metros, do segundo pavimento em diante, levando a plantas comercialmente inviáveis ao se aplicar o coeficiente de aproveitamento permitido de 3,5 vezes a área do lote. Cujo resultado seria uma edificação alta, extremamente estreita, ladeada por paredes cegas ainda mais altas, possivelmente construídas antes de 1957.

Entende-se que, atualmente, presencia-se o fim deste fluxo urbano em função da Operação Urbana Centro (Lei oo 12.349 de 1997). Os atuais distritos Sé e República estão contidos no perímetro desta lei, que incentiva o agrupamento de lotes, a fim de que possam ser aplicados os critérios urbanísticos consolidados em 1972, presentes na legislação urbana vigente hoje - quanto à iluminação e ventilação dos edifícios, suas taxas de ocupação e coeficientes de aproveitamento.

Se forem considerados o grande e crônico problema de locomoção dentro da cidade de São Paulo e os valores crescentes de obras implantadas com critérios e métodos construtivos contemporâneos - em regiões cujos lotes foram criados e edificados mais recentemente - será possível prever a médio prazo novas intervenções no 
"centro". Talvez em função de um crescimento de interesse por esta região decorrente da estagnação, ou até diminuição de preços de suas obsoletas edificações e da facilidade de acesso por sua localização dentro da cidade.

De acordo com os critérios previstos na Operação Urbana Centro, vê-se a possibilidade do estabelecimento de escalas mais adequadas entre as novas edificações e os futuros lotes resultantes do reagrupamento de terrenos do século XIX. Porém, nesta lei não está prevista a readequação das vias e do transporte público de massa, em função dos coeficientes de aproveitamento por ela permitidos.

No longo prazo prevê-se uma grande transformação da paisagem urbana no "centro" da cidade, a partir da eliminação de conjuntos de edificações que forem consideradas culturalmente insignificantes, sem valor histórico ou artístico, cujos lotes remembrados tiverem potencial de gerar lucro ao investimento a ser realizado por indivíduos e grupos que, no futuro, forem os motores da construção civil paulistana. No entanto, se as vias e os meios de transporte de massa não forem compatibilizados às escalas dos futuros lotes remembrados, possivelmente será verificada nova incompatibilidade entre as estruturas urbanas físicas e não-físicas. Ou seja, a situação do "centro" será mantida e agravada se não for revisada e consequentemente substituída a Lei oㅜ 12.349 de 1997, de modo que não apenas os lotes, mas também as vias e o transporte público tenham suas escalas compatibilizadas às escalas de edificações permitidas pela legislação atual.

Suposições estas a serem comprovadas, ou não, por novos trabalhos que enfoquem a região central da cidade de São Paulo. Estas futuras pesquisas poderão verificar se os projetos e obras do século XXI terão se adequado com qualidade conceitual, construtiva, urbana e ambiental às novas escalas vivenciadas pelos cidadãos paulistanos - atuais e futuros - que trarão consigo novas tecnologias, meios de transporte e demandas sem precedentes. 


\section{7- REFERÊNCIAS}

ACIOLY, Cláudio; DAVIDSON, Forbes. Densidade Urbana: um instrumento de planejamento e gestão urbana. Rio de Janeiro: Mauad, 1998. 104 p.

ANDRADE, Francisco de Paula Dias de. Subsídios para o estudo da influência da legislação na ordenação e na arquitetura das cidades brasileiras. 1966. 376 p. Tese (Doutorado) - Escola Politécnica, Universidade de São Paulo, São Paulo, 1966.

ANELLI, Renato; GUERRA, Abílio (Coord.). Rino Levi: arquitetura e cidade. Ensaios fotográficos por Nelson Kon. São Paulo: R. Guerra, 2001. 323 p.

ARQUITETURA E URBANISMO. São Paulo, PINI. Publicação de dezembro de 2006. Edifício Fundação Carlos Chagas 2001/2006 - Diálogo mais que possível, p.35.

BLOCH, Luiz Laurent; BOTELHO, Manuel Henrique Campos. Código de obras e edificações do município de São Paulo: comentado e criticado. São Paulo: Pini, 1993. 293 p.

BRUANT, Catherine. Donat Alfred Agache: urbanismo, uma sociologia aplicada. In: RIBEIRO, Luiz César; PECHMAN, Robert (Org). Cidade, povo e nação: gênese do urbanismo moderno. Rio de Janeiro: Civilização Brasileira, 1996.

CAMPOS NETO, Cândido Malta. Os rumos da cidade: 0 urbanismo e modernização em São Paulo. 1999. 2 v. Tese (Doutorado) - Faculdade de Arquitetura e Urbanismo, Universidade de São Paulo, São Paulo, 1999.

CINTRA, Jorge Pimentel. A primeira planta topográfica da cidade de São Paulo. São Paulo: EPUSP, 2001. Disponível em: <http:// www.cartografia.org.br>. Acesso em: 23 jan. 2008

CORDEIRO, Helena Kohn. 0 centro da metrópole paulistana: expansão recente. São Paulo: Faculdade de Filosofia, Letras e Ciências Humanas, Universidade de São Paulo, 1978. 2 v. 
FALBEL, Anat. Lucjan Korngold: a trajetória de um arquiteto imigrante. 2003. 323 p. Tese (Doutorado) - Faculdade de Arquitetura e Urbanismo, Universidade de São Paulo, São Paulo, 2003.

FARIAS, Agnaldo. La Arquitectura de Ruy Ohtake. Madri: Celeste, 1994.

FELDMAN, Sarah. Planejamento e zoneamento: São Paulo 1947-1972. 1996. 207 p. Tese (Doutorado) - Faculdade de Arquitetura e Urbanismo, Universidade de São Paulo, São Paulo, 1996.

FERREIRA FILHO, Manoel Gonçalves. Do processo legislativo. 5.ed. rev., ampl. e atual. São Paulo: Saraiva, 2002. 303 p.

FISCHER, Sylvia. Os arquitetos da Poli: ensino e profissão em São Paulo. São Paulo: EDUSP, 2005. 400 p.

FONTES, Maria Cecília Levy Piza. Processo de intervenção urbanística: requalificação do edifício São Vito. Minha cidade, São Paulo, n. 117, out. 2004. Disponível em: <http://www.vitruvius.com.br/minhacidade/mc117/mc117.asp>. Acesso em: 02 jan. 2008.

FUNDAÇÃO DO DESENVOLVIMENTO ADMINISTRATIVO. 0 planejamento urbano no município de São Paulo: memórias seletivas de suas manifestações no período 1892 a 1964. São Paulo, 1979.

GIAQUINTO, Paulo Ricardo. Legislação, modelos e formas urbanas: São Paulo 72/92. 1995. 3 v. Dissertação (Mestrado) - Faculdade de Arquitetura e Urbanismo, Universidade de São Paulo, São Paulo,1995.

GROSTEIN, Marta Dora. A cidade clandestina: os ritos e os mitos: o papel da "irregularidade" na estruturação do espaço urbano de São Paulo, 1900-1987. 1987. 614 p. Tese (Doutorado) - Faculdade de Arquitetura e Urbanismo, Universidade de São Paulo, São Paulo, 1987.

HARVEY, David. A condição pós-moderna: uma pesquisa sobre as origens da mudança cultural. São Paulo: Loyola, 1992. 349 p.

HOMEM, Maria Cecília Naclério. 0 prédio Martinelli: a ascensão do imigrante e a verticalização de São Paulo. São Paulo: Projeto, 1984. 175 p 
KÖNIGSBERGER, Jorge; ALMEIDA, Lízia M. de. O arquiteto e as leis. São Paulo, Pini, 2004.

LEFEVRE, Henrique Neves. Influência da legislação urbanística sobre a estruturação das cidades: aplicação especial ao caso de São Paulo. São Paulo: s.n., 1951. 1 v. Tese (concurso de cátedra) apresentada a escola de engenharia Mackenzie.

LEFÈVRE, José Eduardo de Assis. De beco à avenida: a história da rua São Luiz. São Paulo: EDUSP, 2006. xvi, 312 p.

O transporte coletivo como agente transformador da estruturação do centro da cidade de São Paulo. 1986. 157 p. Dissertação (Mestrado) - Faculdade de Arquitetura e Urbanismo, Universidade de São Paulo, São Paulo, 1986.

LEME, Maria Cristina da Silva. Formação do urbanismo em São Paulo como campo de conhecimento e área de atuação profissional. 2000. 195 p. Tese (Livre-docência) - Faculdade de Arquitetura e Urbanismo, Universidade de São Paulo, São Paulo, 2000.

Revisão do plano de avenidas: um estudo do planejamento em São Paulo,1930. 1990. 255 p. Tese (Doutorado) - Faculdade de Arquitetura e Urbanismo, Universidade de São Paulo, 1990.

LEMOS, Carlos Alberto Cerqueira Lemos; TOLEDO, Benedito Lima de. Edifícios de valor histórico e paisagístico. São Paulo: COGEP, 1975.

MARCONDES, Claudia de Barros. O poder de transformação urbana da legislação de uso e ocupação do solo no município de São Paulo. 1988. 170 p. Dissertação (Mestrado) - Escola Politécnica, Universidade de São Paulo, São Paulo, 1988.

MARTINS, Maria Lucia Refinetti R. São Paulo metrópole e isso tudo, 1920 a 1980. 1982. 149 p. Tese (Mestrado) - Faculdade de Arquitetura e Urbanismo, Universidade de São Paulo, São Paulo, 1982.

MEYER, Regina Maria Prosperi. Metrópole e urbanismo: São Paulo anos 50. 1991. 290 p. Tese (Doutorado) - Faculdade de Arquitetura e Urbanismo, Universidade de São Paulo, São Paulo, 1991. 
MIRANDA, Jorge. Manual de direito constitucional: preliminares: o estado e os sistemas constitucionais. 5.ed. rev. e actual. Coimbra: Coimbra Editora, 1996. v. 1.

MONTORO, André Franco. Introdução à ciência do direito. São Paulo: Revista dos Tribunais, 1989. $1 \mathrm{v}$.

MORSE, Richard M. Formação histórica de São Paulo: da comunidade à metrópole. São Paulo: DIFEL, 1970. 447 p. (Corpo e Alma do Brasil, v. 30).

NAKANO, K.; CAMPOS, C. M.; ROLNIK, R. Dinâmicas dos subespaços da área central de São Paulo. In: COMIN, Alvaro Augusto; SOMEKH, Nadia. Caminhos para o centro: estratégias de desenvolvimento para a região central de São Paulo. São Paulo: CEM/CEBRAP/EMURB, 2004.

PIRATININGA.ORG. Artigos sobre São Paulo. Disponível em: $<$ http://www.piratininga.org >. Acesso em: 05 jan. 2008.

PORTA, Paula (Org.). História da cidade de São Paulo: a cidade na primeira metade do século XX. São Paulo: Paz e Terra, 2004. v. 3.

PORTAL VITRUVIUS. Universo paralelo de arquitetura e urbanismo. Disponível em: <http://www.vitruvius.com.br>. Acesso em: 20 jan. 2008.

REIS FILHO, Nestor Goulart. Notas sobre urbanização dispersa e novas formas de tecido urbano. São Paulo: Via das Artes, 2006. 201 p.

. Quadro da arquitetura no Brasil. São Paulo: Perspectiva, 1970. 214 p.

São Paulo: vila, cidade, metrópole. São Paulo: Via das Artes, 2004. 261 p.

ROLNIK, Raquel. A cidade e a lei: legislação, política urbana e territórios na cidade de São Paulo. 3. ed. São Paulo: Studio Nobel, 2003. 242 p.

SÃO PAULO (Estado). Decreto $\mathrm{n}^{\circ} 233$, de 02 de março de 1894. O Presidente do Estado, para execução do artigo $3^{\circ}$ da Lei $n^{\circ}$ 2 240, de 04 de setembro de 1893, manda que se observe o seguinte Código Sanitário. Referência Legislativa Municipal de São Paulo, Coletânea de leis: 1894, São Paulo, p. 9 a 43. 
SÃO PAULO (Estado). Decreto $n^{0} 2141$, de 14 de novembro de 1911. O Presidente do Estado de São Paulo, decreta e manda que seja o Serviço Sanitário do Estado reorganizado nos termos do Regulamento que com este baixa. Referência Legislativa Municipal de São Paulo, Coletânea de leis : 1911, São Paulo, p. 376 a 449.

SÃO PAULO (Estado). Lei $\mathrm{n}^{0}$ 1596, de 29 de dezembro de 1917. Reorganiza o Serviço Sanitário do Estado. Referência Legislativa Municipal de São Paulo, Coletânea de leis: 1917, São Paulo, p. 158 a 207.

SÃO PAULO (Município). Ato $\mathrm{n}^{\circ} 26$, de 18 de outubro de 1898. Resolve sobre o assentamento de postes de ferro ou de madeira nas ruas, bem como de cabos e fios para transmissão de forca e luz elétrica. Diário Oficial, São Paulo, 18 outubro 1898, fl. 1.

SÃO PAULO (Município). Ato $\mathrm{n}^{\circ}$ 127, de 20 de março de 1931. Institui o Zoning, para determinados distritos urbanos e constitui uma comissão para o estudo desse problema, em toda a cidade. Diário Oficial, São Paulo, 20 março 1931, fl. 1.

SÃO PAULO (Município). Ato $n^{\circ} 384$, de 21 de setembro de 1932. Da interpretação ao artigo $1^{\circ}$ do Ato $n^{\circ}$ 127, de 20/03/1931, que institui o Zoning para determinados distritos urbanos. Diário Oficial, São Paulo, 21 setembro 1932, fl. 1.

SÃO PAULO (Município). Ato $\mathrm{n}^{\circ}$ 663, de 10 de agosto de 1934. Aprova a consolidação do Código de Obras Arthur Soboya, (Lei no 4327, de 19 de novembro de 1929) abrangendo todas as disposições constantes de leis e atos em vigor nesta data, referentes a construções, arruamentos, etc. Diário Oficial, São Paulo, 10 agosto 1934, fl. 1.

SÃO PAULO (Município). Ato $n^{\circ}$ 699, de 07 de julho de 1914. Dá a denominação a novas ruas abertas na Vila América. Diário Oficial, São Paulo, 07 julho 1914, fl. 1.

SÃO PAULO (Município). Ato $\mathrm{n}^{0} 769$, de 14 de junho de 1915. Regulamenta a Lei no 1666, de 26 de março de 1913 e as disposições legais referentes a vias públicas por essa lei não revogadas. Diário Oficial, São Paulo, 14 junho 1915, fl. 1.

SÃO PAULO (Município). Ato $\mathrm{n}^{\circ} 815$, de 26 de novembro de 1915. Regulamenta a Lei no 1756, de 2 dezembro de 1913 que dispõe sobre serviços e empregos municipais, e a parte do Ato no 573, de 16 de abril de 1913, com força de lei, por ela não reformada, na parte referente a diretoria de obras e viação. Diário Oficial, São Paulo, 26 novembro 1915, fl. 1. 
SÃO PAULO (Município). Ato $\mathrm{n}^{\circ} 816$, de 26 de novembro de 1915. Desempenharão os cargos referidos no Ato no 815, de 26 de novembro de 1915, os seguintes funcionários do quadro. Diário Oficial, São Paulo, 26 novembro 1915, fl. 1.

SÃO PAULO (Município). Ato $\mathrm{n}^{\circ} 849$, de 27 de janeiro de 1916. Regulamenta a Lei ํo 1874, de 12 de maio de 1915, e as disposições legais referentes a construções por essa lei não revogadas. Diário Oficial, São Paulo, 27 janeiro 1916, fl. 1.

SÃO PAULO (Município). Ato $\mathrm{n}^{\circ} 900$, de 17 de maio de 1916. Expede instruções para boa execução do parágrafo único do artigo 75 , do Ato no 849 , de 27 de janeiro de 1916. Diário Oficial, São Paulo, 17 maio 1916, fl. 1.

SÃO PAULO (Município). Ato $n^{\circ}$ 969, de 07 de dezembro de 1935. Revigora a Lei $n^{\circ}$ 2323, de 30 de setembro de 1920 e dá outras providências. Diário Oficial, São Paulo, 07 dezembro 1935, fl. 1.

SÃO PAULO (Município). Ato $\mathrm{n}^{\circ} 1013$, de 13 de fevereiro de 1936. Estabelece normas para denominação das vias públicas, numeração de imóveis, emplacamento e registro das ruas particulares. Diário Oficial, São Paulo, 13 fevereiro 1936, fl. 1.

SÃO PAULO (Município). Ato $\mathrm{n}^{\circ} 1235$, de 11 de maio de 1918. Regulamenta a Lei $\mathrm{n}^{\circ}$ 2119 , de 16 de fevereiro de 1918, que adota, para incorporar as posturas municipais, a Lei Estadual no 1596, de 29 de dezembro de 1917, na parte referente a construção e reconstrução de prédios. Diário Oficial, São Paulo, 11 maio 1918, fl. 1.

SÃO PAULO (Município). Ato $\mathrm{n}^{0}$ 1335, de 12 de janeiro de 1938. Aceita e da denominação de Marconi a rua aberta entre as ruas Barão de Itapetininga e 7 de Abril, no subdistrito de Santa Ifigênia. Diário Oficial, São Paulo, 12 janeiro 1938, fl.1.

SÃO PAULO (Município). Ato $\mathrm{n}^{\circ} 1366$, de 19 de fevereiro de 1938. Modifica o artigo 181 do Ato no 663, de 1934, que regula as edificações da Rua Barão de Itapetininga e outras, e dá outras providências. Diário Oficial, São Paulo, 19 fevereiro 1938, fl. 1.

SÃO PAULO (Município). Ato $n^{0} 1373$, de 15 de março de 1938. Regula as edificações à Rua Formosa. Diário Oficial, São Paulo, 15 março 1938, fl. 1.

SÃO PAULO (Município). Ato $\mathrm{n}^{\circ}$ 1470, de 14 de setembro de 1938. Aprova o plano de alargamento da Rua Ipiranga e dá outras providências. Diário Oficial, São Paulo, 14 setembro 1938, fl. 1. 
SÃO PAULO (Município). Ato $n^{0} 1496$, de 25 de outubro de 1938. Dispõe sobre construções na avenida Nove de Julho, entre a Alameda Itú e a Rua Estados Unidos, nas rampas de acesso a Alameda Jaú e no jardim sobre o túnel. Diário Oficial, São Paulo, 25 outubro 1938, fl. 1.

SÃO PAULO (Município). Decreto $n^{0} 3776$, de 03 de janeiro de 1958. Regulamenta a Lei $n^{\circ}$ 5261/57, que estabelece coeficiente de aproveitamento de lotes. Diário Oficial, São Paulo, 04 janeiro 1958, fl. 5.

SÃO PAULO (Município). Decreto $n^{0} 6766$, de 23 de novembro de 1966. Dispõe sobre denominação de logradouro publico. Diário Oficial, São Paulo, 25 novembro 1966, fl. 1.

SÃO PAULO (Município). Decreto ${ }^{\circ} 8898$, de 28 de julho de 1970. Dá nova redação ao parágrafo único do artigo 18 do Decreto № 3962/58. Diário Oficial, São Paulo, 29 julho 1970, fl. 2.

SÃO PAULO (Município). Decreto $n^{\circ} 11106$, de 28 de junho de 1974. Regulamenta as Leis no 7805/72 e 8001/73, que dispõem sobre a divisão do território do município em zonas de uso e regulam o parcelamento, uso e ocupação do solo e dá outras providências. Diário Oficial, São Paulo, 27 setembro 1974, fl. 3.

SÃO PAULO (Município). Decreto $n^{0} 12706$, de 08 de março de 1976. Estabelece normas para utilização de gás combustível nos edifícios e construções em geral, regulamentando os artigos 105 e 110 da Lei oㅡ 8266/75, e dá outras providências. Diário Oficial, São Paulo, 19 março 1976, fl. 4.

SÃO PAULO (Município). Decreto $\mathrm{n}^{\circ}$ 13588, de 20 de setembro de 1976. Complementa o quadro no 8 , referente a recuos de edificações, anexo ao Decreto no 11106/74; dá nova redação, acrescentando-lhe dois parágrafos, ao artigo 64 daquele decreto, que regulamenta os itens VIII e IX do artigo 15 da Lei № 7805/72, e dá outras providências. Diário Oficial, São Paulo, 21 setembro 1976, fl. 7.

SÃO PAULO (Município). Decreto $n^{\circ}$ 14025, de 19 de novembro de 1976. Regulamenta os artigos 516,522,523 e 565 da Lei no 8266/75, fixando normas especiais para arruamentos, loteamentos, conjuntos habitacionais, edificações de interesse social, e dá outras providências. Diário Oficial, São Paulo, 20 setembro 1976, fl. 1.

SÃO PAULO (Município). Decreto $n^{\circ} 14676$, de 02 de setembro de 1977. Permite o uso do título precário e gratuito pela empresa municipal de urbanização - EMURB, 
de área de propriedade municipal - situada no subsdistrito de Vila Guilherme. Diário Oficial, São Paulo, 03 setembro 1977, fl. 1.

SÃO PAULO (Município). Decreto $\mathrm{n}^{\circ} 15047$, de 03 de maio de 1978. Dá nova redação ao parágrafo $1^{\circ}$ do inciso II do artigo 20, acrescenta a alínea"s" ao parágrafo $3^{0}$ do inciso II do mesmo artigo de Decreto № 14025/76, e substitui o quadro 2 anexo ao mesmo decreto. Diário Oficial, São Paulo, 04 maio 1978, fl. 2.

SÃO PAULO (Município). Decreto $n^{\circ}$ 15763, de 22 de março de 1979. Regulamenta a fixação de trechos de logradouros públicos nas zonas de uso Z5-001 e Z5-002, para efeitos de instalação de estacionamentos, garagens e pátios de carga e descarga, e dá outras providências. Diário Oficial, São Paulo, 23 março 1979, fl. 1.

SÃO PAULO (Município). Decreto $n^{0} 15980$, de 29 de junho de 1979. Dispõe sobre ordenamento do processo especial de aprovação de projetos de edificações de que se trata o item IV do artigo $7^{\circ}$ da lei $8777 / 78$, regulamenta, parcialmente, a parte e da Lei nº 8266/75, e dá outras providências. Diário Oficial, São Paulo, 05 julho 1979, fl. 5.

SÃO PAULO (Município). Decreto $\mathrm{n}^{0}$ 16656, de 15 de maio de 1980. Altera a redação ao artigo 25 do Decreto ํㅜ 14025/76, e dá outras providências. Diário Oficial, São Paulo, 16 maio 1980, fl. 2.

SÃO PAULO (Município). Decreto $n^{0}$ 17810, de 04 de fevereiro de 1982. Regulamenta, parcialmente, os artigos 523 e 565 da Lei ํㅜ 8266/75, com a nova redação conferida pela Lei $\mathrm{n}^{\circ}$ 9414/81, fixando normas técnicas especiais para programas habitacionais de interesse social, desenvolvidos por entidades privadas, e dá outras providências. Diário Oficial, São Paulo, 10 fevereiro 1982, fl. 3.

SÃO PAULO (Município). Decreto $n^{\circ} 18855$, de 21 de junho de 1983. Regulamenta a Lei no 9602/83, que dispõe sobre a transferência de edificações do setor de edificações irregulares do cadastro de edificações do município para o setor de edificações regulares, e dá outras providências. Diário Oficial, São Paulo, 23 junho 1983, fl. 2.

SÃO PAULO (Município). Decreto $\mathrm{n}^{0} 22104$, de 09 de abril de 1986. Confere nova redação a alínea "d" do item III do artigo 3ㄴ, ao parágrafo único do artigo 12 e aos artigos 15 e 16 do Decreto no 17810/82. Diário Oficial, São Paulo, 10 abril 1986, fl.2. 
SÃO PAULO (Município). Decreto $n^{0} 22384$, de 30 de junho de 1986. Acrescenta parágrafo único ao artigo $1^{\circ}$ do Decreto ํㅜ 14025/76. Diário Oficial, São Paulo, 01 julho 1986, fl. 1.

SÃO PAULO (Município). Decreto $n^{\circ} 22684$, de 28 de agosto de 1986. Regulamenta a instalação de coberturas metálicas reguláveis, com base no artigo 566 da Lei no 8266/75. Diário Oficial, São Paulo, 29 agosto 1986, fl. 1.

SÃO PAULO (Município). Decreto $n^{\circ} 23355$, de 29 de janeiro de 1987. Regulamenta a Lei no 10199/86, que dispõe sobre a regularização de edificações em situação irregular no município. Diário Oficial, São Paulo, 30 janeiro 1987, fl. 1.

SÃO PAULO (Município). Decreto $n^{0} 23405$, de 09 de fevereiro de 1987. Dispõe sobre permissão para instalação de guaritas nos passeios públicos, e dá outras providências. Diário Oficial, São Paulo, 10 fevereiro 1987, fl. 1.

SÃO PAULO (Município). Decreto $\mathrm{n}^{0}$ 24714, de 07 de outubro de 1987. Regulamenta o sistema de fiscalização, disposições gerais para utilização de gás combustível nos edifícios e construções em geral e da outras providencias. Diário Oficial, São Paulo, 08 outubro 1987, fl. 1.

SÃO PAULO (Município). Decreto $n^{\circ} 24757$, de 14 de outubro de 1987. Da nova redação ao par.2 do art.4 do Decreto № 24.714/87. Diário Oficial, São Paulo, 15 outubro 1987, fl. 1.

SÃO PAULO (Município). Decreto $\mathrm{n}^{\circ} 25484$, de 07 de março de 1988. Autoriza o recebimento de pedidos de regularização de edificações baseados na Lei no 10.199/86, em hipótese que especifica, e dá outras providências. Diário Oficial, São Paulo, 08 março 1988, fl. 2.

SÃO PAULO (Município). Decreto ${ }^{0} 26913$, de 16 de setembro de 1988. Estabelece procedimentos referentes a operações interligadas, objeto da Lei no $10209 / 86$, e dá outras providências. Diário Oficial, São Paulo 17 setembro 1988, fl. 2.

SÃO PAULO (Município). Decreto $n^{0} 29079$, de 25 de setembro de 1990. Revoga o Decreto no 26360/88, que dispõe sobre o tombamento de imóveis localizados no Largo de São Francisco. Diário Oficial, São Paulo, 26 setembro 1990, fl. 1.

SÃO PAULO (Município). Decreto $n^{\circ} 29551$, de 28 de fevereiro de 1991. Altera parcialmente o anexo I do Decreto ํㅡ 15763/79, e dá outras providências. Diário Oficial, São Paulo, 01 março 1991, fl. 1. 
SÃO PAULO (Município). Decreto $n^{\circ} 29851$, de 21 de junho de 1991. Cria área especial de intervenção e ordenação da paisagem urbana no trecho que especifica; institui o grupo executivo do projeto eixo "Sé-Arouche", e dá outras providencias. Diário Oficial, São Paulo, 28 junho 1991, fl. 1.

SÃO PAULO (Município). Decreto $\mathrm{n}^{\circ}$ 30731, de 12 de dezembro de 1991. Regulamenta a Lei no 10928/91, que dispõe sobre as condições de habitação dos cortiços, cria a comissão de intervenção e recuperação dos cortiços, e dá outras providências. Diário Oficial, São Paulo, 13 dezembro 1991, fl. 1.

SÃO PAULO (Município). Decreto ${ }^{\circ} 31872$, de 14 de julho de 1992 . Altera no tópico relativo à zona de uso especial, Z8-200-001, o quadro I, anexo ao Decreto oo 19835/84, e dá outras providências. Diário Oficial, São Paulo, 15 julho 1992, fl. 1.

SÃO PAULO (Município). Decreto $n^{\circ}$ 32329, de 23 de setembro de 1992. Regulamenta a Lei no 11.228/92-código de obras e edificações, e dá outras providências. Diário Oficial, São Paulo, 26 setembro 1992, fl. 2.

SÃO PAULO (Município). Decreto Lei $n^{0} 23$, de 17 de fevereiro de 1940. Dispõe sobre alteração e ratificação de plano de melhoramentos aprovados pelo Ato no 1470, de 14 de setembro de 1938. Diário Oficial, São Paulo, 17 fevereiro 1940, fl. 1.

SÃO PAULO (Município). Decreto Lei ${ }^{\circ} 41$, de 03 de agosto de 1940. Regulamenta as construções na Avenida Ipiranga e dá outras providências. Diário Oficial, São Paulo, 03 agosto 1940, fl. 1.

SÃO PAULO (Município). Decreto Lei $\mathrm{n}^{\circ}$ 75, de 11 de fevereiro de 1941. Regulamenta as construções na Avenida 9 de Julho e dá outras providências. Diário Oficial, São Paulo, 11 fevereiro 1941, fl. 1.

SÃO PAULO (Município). Decreto Lei $n^{\circ}$ 92, de 02 de maio de 1941. Dispõe sobre regulamentação especial de comunicações na zona central, altera o perímetro desta e dá outras providências. Diário Oficial, São Paulo, 02 maio 1941, fl. 1.

SÃO PAULO (Município). Decreto Lei n ${ }^{0} 145$, de 13 de março de 1942. Dispõe sobre o lançamento e arrecadação do imposto predial urbano. Diário Oficial, São Paulo, 13 março 1942, fl. 18.

SÃO PAULO (Município). Decreto Lei $n^{\circ} 400,28$ de fevereiro de 1947. Regula a altura dos edifícios à Rua Formosa. Diário Oficial, São Paulo, 28 fevereiro 1947, fl. 19. 
SÃO PAULO (Município). Decreto Lei $n^{\circ} 431,09$ de julho de 1947. Dispõe sobre a reorganização administrativa da Secretaria de Obras, e dá outras providências. Diário Oficial, São Paulo, 09 julho 1947, fl. 24.

SÃO PAULO (Município). Lei ${ }^{\circ} 38$, de 24 de maio de1893. Estabelece a aprovação de plantas para as novas edificações. Diário Oficial, São Paulo, 24 maio 1893, fl. 1.

SÃO PAULO (Município). Lei $n^{\circ} 220$, de 18 de março de 1896. Obriga a demolição de qualquer edifício, muro ou obra que ameaça ruína, ou estiver construído fora do Padrão Municipal. Diário Oficial, São Paulo, 18 março 1896, fl. 1.

SÃO PAULO (Município). Lei $n^{\circ} 274$, de 28 de agosto de 1896. Marca a altura que devem ser colocados os toldos das casas comerciais. Diário Oficial, São Paulo, 28 agosto 1896, fl. 1.

SÃO PAULO (Município). Lei $\mathrm{n}^{\circ}$ 297, de 07 de dezembro de 1896. Declara de utilidade pública o terreno situado no Largo de São Bento, ocupado pelos prédios números 11 e 13. Diário Oficial, São Paulo, 07 dezembro 1896, fl. 1.

SÃO PAULO (Município). Lei $n^{\circ} 374$, de 29 de outubro de 1898. Organiza o Poder Executivo Municipal. Diário Oficial, São Paulo, 29 outubro 1898, fl. 1.

SÃO PAULO (Município). Lei n ${ }^{\circ} 355$, de 03 de junho de 1898. Especifica o modo de edificar nas avenidas Higienópolis e Itatiaia. Diário Oficial, São Paulo, 03 junho 1898, fl. 1.

SÃO PAULO (Município). Lei $n^{\circ} 498$, de 14 de dezembro de 1900. Estabelece prescrições para construção de casas de habitação operária. Diário Oficial, São Paulo, 14 dezembro 1900, fl. 1.

SÃO PAULO (Município). Lei $n^{0} 722$, de 26 de março de 1904. Regula a verificação de alinhamento. Diário Oficial, São Paulo, 26 março 1904, fl. 1.

SÃO PAULO (Município). Lei $n^{\circ} 761$, de 20 de julho de 1904. Estabelece favores para os proprietários de terrenos que forem edificados nas ruas Barão de Itapetininga e Conselheiro Crispiniano. Diário Oficial, São Paulo, 20 julho 1904, fl.1.

SÃO PAULO (Município). Lei $n^{0}$ 1011, de 06 de julho de 1907. Estabelece diversos favores aos proprietários que construírem prédios com mais de dois pavimentos 
sobre o solo, adotando fachadas aprovadas pela prefeitura em determinadas ruas. Diário Oficial, São Paulo, 06 julho 1907, fl. 1.

SÃO PAULO (Município). Lei $n^{\circ} 1331$, de 06 de junho de 1910. Aprova o Plano de Melhoramentos da zona dominada pelo Viaduto do Chá. Diário Oficial, São Paulo, 06 junho 1910, fl. 1.

SÃO PAULO (Município). Lei $n^{0} 1484$, de 24 de novembro de 1911. Declara de utilidade pública os terrenos necessários para o alargamento da Rua da Conceição e prolongamento da Rua Dom José De Barros. Diário Oficial, São Paulo, 24 novembro 1911, fl. 1.

SÃO PAULO (Município). Lei $n^{\circ} 1580$, de 22 de agosto de 1912. Proíbe qualquer obra de acréscimo ou de adaptação dos prédios urbanos que estiverem construídos em desacordo com o Padrão. Diário Oficial, São Paulo, 22 agosto 1912, fl. 1.

SÃO PAULO (Município). Lei $n^{0} 1585$, de 03 de setembro de 1912. Dispõe sobre alinhamento de construções. Diário Oficial, São Paulo, 03 setembro 1912, fl. 1.

SÃO PAULO (Município). Lei $n^{0}$ 1596, de 27 de setembro de 1912. Aprova a planta de alargamento da Rua São João, desde a Praça Antonio Prado até a Rua Lopes de Oliveira. Diário Oficial, São Paulo, 27 setembro 1912, fl. 1.

SÃO PAULO (Município). Lei $n^{0}$ 1666, de 26 de março de 1913. Dispõe sobre a abertura de ruas, avenidas ou praças. Diário Oficial, São Paulo, 26 março 1913, fl.1.

SÃO PAULO (Município). Lei $n^{\circ}$ 1756, de 02 de dezembro de 1913. Dispõe sobre serviços e empregos municipais. Diário Oficial, São Paulo 02 dezembro 1913, fl. 1.

SÃO PAULO (Município). Lei $n^{0} 1788$, de 28 de maio de 1914. Divide em três perímetros o município da capital. Diário Oficial, São Paulo, 28 maio 1914, fl. 1.

SÃO PAULO (Município). Lei ${ }^{\circ}$ 1874, de 12 de maio de 1915. Divide o município em quatro perímetros e dá outras providências. Diário Oficial, São Paulo, 12 maio 1915, fl. 1.

SÃO PAULO (Município). Lei ${ }^{\circ}$ 1901, de 07 de agosto de 1915. Modifica o artigo 3ㅜ, da lei 1596, de 27 de setembro de 1912. Diário Oficial, São Paulo, 07 agosto 1915, fl. 1. 
SÃO PAULO (Município). Lei $\mathrm{n}^{\circ} 2119$, de 16 de fevereiro de 1918. Autoriza a municipalidade a adotar, para incorporar às suas posturas, a lei estadual 1596/17, na parte referente às construções e reconstruções de prédios urbanos. Diário Oficial, São Paulo, 16 fevereiro 1918, fl. 1.

SÃO PAULO (Município). Lei $n^{0} 2332$, de 09 de novembro de 1920. Estabelece o Padrão Municipal, para as construções particulares do município. Diário Oficial, São Paulo, 09 novembro 1920, fl. 1.

SÃO PAULO (Município). Lei ${ }^{0} 2611$, de 20 de junho de 1923. Proíbe a abertura de vias de comunicação, em qualquer perímetro do município, sem prévia licença da prefeitura. Diário Oficial, São Paulo, 20 junho 1923, fl. 1.

SÃO PAULO (Município). Lei ${ }^{\circ} 3272$, de 05 de março de 1929. Aprova o traçado de toda a Avenida Itororó, de acordo com a planta organizada pela comissão da Avenida Anhangabaú. Diário Oficial, São Paulo, 05 março 1929, fl. 1.

SÃO PAULO (Município). Lei n ${ }^{\circ} 3427$, de 19 de novembro de 1929. Código de Obras Arthur Saboya. Diário Oficial, São Paulo, 19 novembro 1929, fl. 1.

SÃO PAULO (Município). Lei $n^{\circ} 3571$, de 07 de abril de 1937. Declara aplicáveis às avenidas Paulista, Higienópolis, Angélica, Pedro I, Pompéia e Rua Maranhão as exigências do artigo 40 do Ato № 663, de 10 de agosto de 1934. Diário Oficial, São Paulo, 07 abril 1937, fl. 1.

SÃO PAULO (Município). Lei $n^{0} 3783$, de 05 de julho de 1949. Dá nova redação ao artigo $1^{\circ}$ do Decreto-Lei 92/41. Diário Oficial, São Paulo, 06 julho 1949, fl. 38.

SÃO PAULO (Município). Lei $n^{\circ} 4505$, de 25 de junho de 1954. Dispõe sobre aberturas de ruas e dá outras providências. Diário Oficial, São Paulo, 25 junho 1954, fl. 19.

SÃO PAULO (Município). Lei $n^{\circ} 4615$, de 13 de janeiro de 1955. Regula as condições gerais das edificações. Diário Oficial, São Paulo, 29 janeiro 1955, fl. 54.

SÃO PAULO (Município). Lei ${ }^{0} 5015$, de 21 de junho de 1956. Autoriza a expedição de alvarás de conservação às obras construídas clandestinamente e dá outras providências. Diário Oficial, São Paulo, 22 junho 1956, fl. 62. 
SÃO PAULO (Município). Lei $\mathrm{n}^{\circ} 5261$, de 04 de julho de 1957. Estabelece coeficiente de aproveitamento de lotes, densidade demográfica, área mínima de lote por habitação e área mínima de espaços livres, e dá outras providências. Diário Oficial, São Paulo, 06 julho 1957, fl. 5.

SÃO PAULO (Município). Lei $n^{0} 5268$, de 04 de julho de 1957. Estabelece obrigatoriedade de se construírem nas novas edificações, garagens ou espaço para estacionamento, carga e descarga de veículos, e dá outras providências. Diário Oficial, São Paulo, em 05 julho 1957, fl. 5.

SÃO PAULO (Município). Lei n ${ }^{\circ}$ 5819, de 22 de junho de 1961. Altera disposições da Lei no-4505/64, e dá outras providências. Diário Oficial, São Paulo, 24 junho 1961, fl.1.

SÃO PAULO (Município). Lei $n^{0}$ 6877, de 11 de maio de 1966. Dispõe sobre os índices máximos de aproveitamento dos terrenos para fins de edificação e reserva de espaços livres, nos arruamentos, e dá outras providências. Diário Oficial, São Paulo, 13 maio 1966, fl. 1.

SÃO PAULO (Município). Lei $n^{0} 7805$, de 01 de novembro de 1972. Dispõe sobre o parcelamento, uso e ocupação do solo do município, e dá outras providências. Diário Oficial, São Paulo, 08 dezembro 1972, fl. 1.

SÃO PAULO (Município). Lei $n^{\circ} 8001$, de 24 de dezembro de 1973. Dispõe sobre o uso e a ocupação do solo urbano, altera e complementa a Lei no 7805/72, e dá outras providências. Diário Oficial, São Paulo, 28 dezembro 1973, fl. 1.

SÃO PAULO (Município). Lei $\mathrm{n}^{0} 8006$, de 08 de janeiro de 1974. Estabelece condições de aproveitamento, ocupação e recuos para edificações destinadas a hotéis de turismo, e dá outras providências. Diário Oficial, São Paulo, 11 janeiro 1974, fl. 2.

SÃO PAULO (Município). Lei $\mathrm{n}^{0}$ 8076, de 26 de junho de 1974. Estabelece condições de aproveitamento, ocupação e recuos para edificações destinadas a hospitais. Diário Oficial, São Paulo, 28 junho 1974, fl. 4.

SÃO PAULO (Município). Lei $\mathrm{n}^{\circ}$ 8211, de 06 de março de 1975. Estabelece condições de localização, aproveitamento, ocupação e recuos para edificações destinadas a estabelecimentos de ensino pertencentes ao sistema educacional do Estado de São Paulo e aos estabelecimentos de educação infantil. Diário Oficial, São Paulo, 14 março 1975, fl. 2. 
SÃO PAULO (Município). Lei n 8266, de 20 de junho de 1975. Aprova o Código de Edificações, e dá outras providências. Diário Oficial, São Paulo, 21 junho 1975, fl.1.

SÃO PAULO (Município). Lei $n^{\circ} 8328$, de 02 de dezembro de 1975. Dispõe sobre o parcelamento, uso e ocupação do solo no município, nas zonas de usos especiais Z8, cria novas zonas de uso, amplia zonas existentes e dá outras providências. Diário Oficial, São Paulo, 03 dezembro 1975, folha 1.

SÃO PAULO (Município). Lei $\mathrm{n}^{\circ}$ 8767, de 22 de agosto de 1978. Corrige discrepâncias entre textos e mapas a que se referem às Leis no 8001/73 8328/78, e dá outras providências. Diário Oficial, São Paulo, 31 agosto 1978, fl. 7.

SÃO PAULO (Município). Lei $\mathrm{n}^{\circ}$ 8769, de 31 de agosto de 1978. Dispõe sobre parcelamento, uso e ocupação do solo no município, nas zonas de uso especial Z8, nas áreas especiais de urbanização, e dá outras providências. Diário Oficial, São Paulo, 01 setembro 1978, fl. 1.

SÃO PAULO (Município). Lei $n^{\circ}$ 8884, de 04 de abril de 1979. Aprova Plano de Melhoramentos no 42 subdistrito Jabaquara; transfere áreas da classe dos bens públicos de uso comum para a dos bens dominicais; dispõe sobre permuta de áreas; autoriza integralização de aumento de capital da empresa municipal de urbanização EMURB, e dá outras providências. Diário Oficial, São Paulo, 05 abril 1979, fl. 1.

SÃO PAULO (Município). Lei $\mathrm{n}^{0}$ 8881, de 29 de março de 1979. Altera e complementa dispositivos das Leis no 8266/75, 7805/72, 8001/73 e 8328/75, e dá outras providências. Diário Oficial, São Paulo, 05 abril 1979, fl. 20.

SÃO PAULO (Município). Lei $n^{\circ}$ 9049, de 24 de abril de 1980. Cria e determina características básicas das zonas de uso Z17 e Z18; cria e altera perímetros de zonas de uso; altera dispositivos para os corredores de uso especial Z8-CR6, enquadra logradouros públicos como corredores de uso especial, e dá outras providências. Diário Oficial, São Paulo, 25 abril 1980, fl. 1.

SÃO PAULO (Município). Lei $n^{\circ}$ 9199, de 18 de dezembro de 1980. Dispõe sobre obrigatoriedade de construção de rampas que permitam o acesso de deficientes físicos. Diário Oficial, São Paulo, 19 dezembro 1980, fl. 3.

SÃO PAULO (Município). Lei n ${ }^{\circ}$ 9334, de 13 de outubro de 1981. Substitui o quadro "7a" anexo à Lei no 8001/73. Diário Oficial, São Paulo, 14 outubro 1981, fl. 1. 
SÃO PAULO (Município). Lei n ${ }^{\circ} 9413$, de 30 de dezembro de 1981. Dispõe sobre o parcelamento do solo do município de São Paulo, e dá outras providências. Diário Oficial, São Paulo, 31 dezembro 1981, fl. 34.

SÃO PAULO (Munić́pio). Lei $n^{\circ}$ 9602, de 11 de fevereiro de 1983. Dispõe sobre a transferência de edificações do setor de edificações irregulares do cadastro de edificações do município para o setor de edificações regulares, e dá outras providências. Diário Oficial, São Paulo, 19 fevereiro 1983, fl. 1.

SÃO PAULO (Município). Lei n ${ }^{\circ} 9843$, de 04 de janeiro de 1985. Fixa prazo máximo para os pedidos de regularização de edificações a que se refere o artigo $5^{\circ}$ da Lei $n^{\circ}$ 9602/83, e dá nova redação ao parágrafo $3^{\circ}$ do artigo $5^{\circ}$ da Lei oㅜ 8382/76. Diário Oficial, São Paulo, 05 janeiro 1985, fl. 4.

SÃO PAULO (Município). Lei ${ }^{\circ} 10032$, de 27 de dezembro de 1985. Dispõe sobre a criação de um conselho municipal de preservação do patrimônio histórico, cultural e ambiental da cidade de São Paulo. Diário Oficial, São Paulo, 28 dezembro 1985, fl.1.

SÃO PAULO (Município). Lei ${ }^{0} 10071$, de 03 de junho de 1986. Faculta o executivo permitir a instalação de caixas eletrônicas bancárias em lotes urbanos. Diário Oficial, São Paulo, 04 junho 1986, fl. 1.

SÃO PAULO (Município). Lei $n^{0} 10093$, de 08 de julho de 1986. Dispõe sobre a inclusão de imóvel de caráter histórico e cultural na zona de uso especial Z8-200. Diário Oficial, São Paulo, 09 julho 1986, fl. 1.

SÃO PAULO (Município). Lei $n^{\circ} 10094$, de 08 de julho de 1986. Introduz alterações no quadro no 78 , anexo à Lei oㅡ 8001/73. Diário Oficial, São Paulo, 09 julho 1986, fl.1.

SÃO PAULO (Município). Lei n ${ }^{\circ} 10169$, de 20 de outubro de 1986. Altera dispositivos da Lei oㅛ 8266/75. Diário Oficial, São Paulo, 21 outubro 1986, fl. 1.

SÃO PAULO (Município). Lei n ${ }^{0} 10209$, de 09 de dezembro de 1986. Dispõe sobre a construção de habitações de interesse social para moradores de habitação subnormal, concede incentivos, e dá outras providências. Diário Oficial, São Paulo, 10 dezembro 1986, fl. 1.

SÃO PAULO (Município). Lei $\mathrm{n}^{\circ} 10236$, de 16 de dezembro de 1986. Altera dispositivos da Lei ํㅜ 10032/85, que dispõe sobre a criação do conselho municipal 
de preservação do patrimônio histórico, cultural e ambiental da cidade de São Paulo - CONPRESP. Diário Oficial, São Paulo, 17 dezembro 1986, fl. 4.

SÃO PAULO (Município). Lei n ${ }^{0} 10334$, de 13 de julho de 1987. Cria áreas especiais de tráfego; fixa regras para sua implantação em diferentes áreas do município; estabelece normas destinadas a estacionamento de veículos; altera e completa dispositivos das Leis no $8266 / 75$ e 8881/79, e dá outras providências. Diário Oficial, 15 julho 1987, fl. 2.

SÃO PAULO (Município). Lei $\mathrm{n}^{\circ}$ 10518, de 16 de maio de 1988. Dispõe sobre limpeza periódica das fachadas dos prédios. Diário Oficial, São Paulo, 17 maio 1988, fl. 1.

SÃO PAULO (Município). Lei $\mathrm{n}^{0} 10598$, de 19 de agosto de 1988. Concede desconto no imposto predial relativo a imóveis que forem restaurados, e dá outras providências. Diário Oficial, São Paulo, 20 agosto 1988, fl. 1.

SÃO PAULO (Município). Lei $n^{0} 10928$, de 08 de janeiro de 1991. Regulamenta o inciso II do artigo 148 combinado com o inciso V do artigo 149 da L.O.M., dispõe sobre as condições de habitação dos cortiços, e dá outras providências (Lei Moura). Diário Oficial, São Paulo, 15 junho 1991, fl. 25.

SÃO PAULO (Município). Lei $\mathrm{n}^{\circ} 11090$, de 16 de setembro de 1991. Estabelece programas de melhorias para a área de influencia imediata do Vale do Anhangabaú, cria incentivos e formas para sua implantação, e dá outras providências. Diário Oficial, São Paulo, 17 setembro 1991, fl. 1.

SÃO PAULO (Município). Lei $n^{0} 11228$, de 25 de junho de 1992. Dispõe sobre as regras gerais e especificas a serem obedecidas no projeto, licenciamento, execução, manutenção e utilização de obras e edificações, dentro dos limites dos imóveis, revoga a Lei $n^{\circ}$ 8.266/75, com as alterações adotadas por leis posteriores, e dá outras providências. Diário Oficial, São Paulo, 26 junho 1992, fl. 1.

SÃO PAULO (Município). Lei $\mathrm{n}^{0}$ 12349, de 06 de junho de 1997. Estabelece programa de melhorias para a área central da cidade, cria incentivos e formas para a sua implantação e dá outras providências. Diário Oficial, São Paulo, 11/06/1997, fl.1.

SÃO PAULO (Município). Lei n ${ }^{0}$ 14106, de 12 de dezembro de 2005. Revoga, em todos os seus termos, nas leis que especifica, relativas ao período de 1892 a 1947, e dá outras providências. Diário Oficial, São Paulo, 13 dezembro 2005, fl. 2. 
SÃO PAULO (Cidade). Prefeitura do município de São Paulo. Disponível em: $<$ http://www.prefeitura.sp.gov.br>. Acesso em: 10 jan. 2008.

Secretaria da Habitação e Desenvolvimento Urbano. Assessoria de Legislação e Normalização Técnica. São Paulo/ edificações: interpretação gráfica, código de edificações. 2. ed. São Paulo: SEHAB, 1989. 181 p.

Secretaria Municipal de Planejamento. Coletânea das leis e decretos de uso e ocupação do solo. São Paulo: COGEP, 1982-1983. 3 v.

SEGAWA, Hugo. Arquiteturas no Brasil 1900-1990. São Paulo: Editora da Universidade de São Paulo, 1999.

SERRA, Geraldo Gomes. O espaço natural e a forma urbana. São Paulo: Nobel, 1976. $211 \mathrm{p}$.

SIMÕES JÚNIOR, José Geraldo. Anhangabaú: história e urbanismo. São Paulo: SENAC/Imprensa Oficial, 2005. $192 \mathrm{p}$.

SKYSCRAPERCITY. São Paulo. Disponível em: <http://www.skyscrapercity.com>. Acesso em: 23 jan. 2008.

SOMEKH, Nadia. A cidade vertical e o urbanismo modernizador: São Paulo 1920-1939. 1994. 253 p. Tese (Doutorado) - Faculdade de Arquitetura e Urbanismo, Universidade de São Paulo, São Paulo, 1994.

A(des)verticalização de São Paulo. 1987. 214 p. Dissertação (Mestrado) Faculdade de Arquitetura e Urbanismo, Universidade de São Paulo, São Paulo, 1987.

TOLEDO, Benedito Lima de. Prestes Maia e as origens do urbanismo moderno em São Paulo. São Paulo: Empresa das Artes, 1996. 297 p.

$179 \mathrm{p}$.

São Paulo, três cidades em um século. São Paulo: Duas Cidades, 1981.

UNIVERSIDADE DE SÃO PAULO. Escola Politécnica. Organização, história, diretores. Disponível em: <http://www.poli.usp.br/Organizacao/Historia/Diretores>. Acesso em: 20 jan. 2008. 
VILLAÇA, Flávio. Espaço intra-urbano no Brasil. São Paulo: Studio Nobel, 1998. $373 \mathrm{p}$.

WAKISAKA, Tânia. Zoneamento de uso e ocupação do solo e produção do espaço urbano em São Paulo. 1991. 238 p. Dissertação (Mestrado) - Faculdade de Arquitetura e Urbanismo, Universidade de São Paulo, São Paulo, 1991.

XAVIER, Alberto; LEMOS, Carlos; CORONA, Eduardo. Arquitetura moderna paulistana. São Paulo: Pini, 1983. 251 p.

ZANETTI, Valdir Zonta. A produção da forma urbana: pinheiros, São Paulo (18901980). 1988. 258 p. Dissertação (Mestrado) - Faculdade de Arquitetura e Urbanismo, Universidade de São Paulo, 1988.

ZMITROWICZ, Witold. As funções urbano-rurais como condicionantes da implantação de zoneamento na cidade de São Paulo. 1979. 162 p. Dissertação (Mestrado) - Escola Politécnica, Universidade de São Paulo, São Paulo, 1979.

A estruturação da cidade pelas rotinas urbanas. São Paulo, Tese de Livre Docência apresentada à Escola Politécnica da Universidade de São Paulo, 1997. 


\section{ANEXO 1 - CONSTRUÇÕES NO PERÍMETRO DE ESTUDO}

Neste anexo são apresentadas 10 obras selecionadas como exemplo de aplicação das leis que regulamentaram as construções privadas na cidade de São Paulo entre 1901 e 2000, dentro do perímetro estudado. São apresentados também 10 projetos, construídos ou não na mesma área.

As construções e projetos localizam-se em vias escolhidas como reflexos relevantes das prescrições legais no campo da construção civil, no "centro" da cidade de São Paulo - atuais distritos Sé e República. A exposição do conjunto de exemplares construídos não se constitui como amostragem estatística, mas como evidência da aplicação da legislação urbana, durante o período estudado. Vale ressaltar a constatação de que o "centro" da cidade, durante todo o período estudado, sempre foi regulamentado por leis urbanas, pois verificou-se que no início do século $X X$, poucas leis referiam-se às áreas fora do "centro" ou perímetro central, áreas consideradas suburbanas ou rurais.

Apesar de construídas 4 anos antes do início do período estudado, como exceção, as edificações à Rua Bento Freitas, esquina com Rua Santa Isabel, devem fazer parte deste trabalho. Foram construídas em 1897 de acordo com a legislação que regulamentou as primeiras duas décadas do século $X X$. Sob os critérios legais do Código de Posturas do Município de 1886 e do Código Sanitário do Estado de São Paulo de 1894, o conjunto de três casas de aluguel, uma de esquina e duas geminadas, foi implantado no alinhamento frontal do lote. A taxa de ocupação do lote, que excede os $90 \%$, e o coeficiente de aproveitamento, que não chega a 2 , resultaram de seu uso, pois estes índices de uso e ocupação do solo não eram regulamentados pelas prescrições legais vigentes quando de sua construção.

De acordo com informações de membros da equipe técnica do Condephaat, Sonia de Deus Rodrigues e Vera Martins, no final do século XIX, o adensamento da área central da cidade de São Paulo influenciou o surgimento de novos bairros como o 
dos Campos Elíseos, Higienópolis e Vila Buarque. Neles se instalaram, de modo geral, famílias ricas ou de classe média. A Vila Buarque surgiu de um loteamento implantado, por volta de 1890, na antiga chácara que pertenceu ao marechal José Arouche de Toledo Rendon.

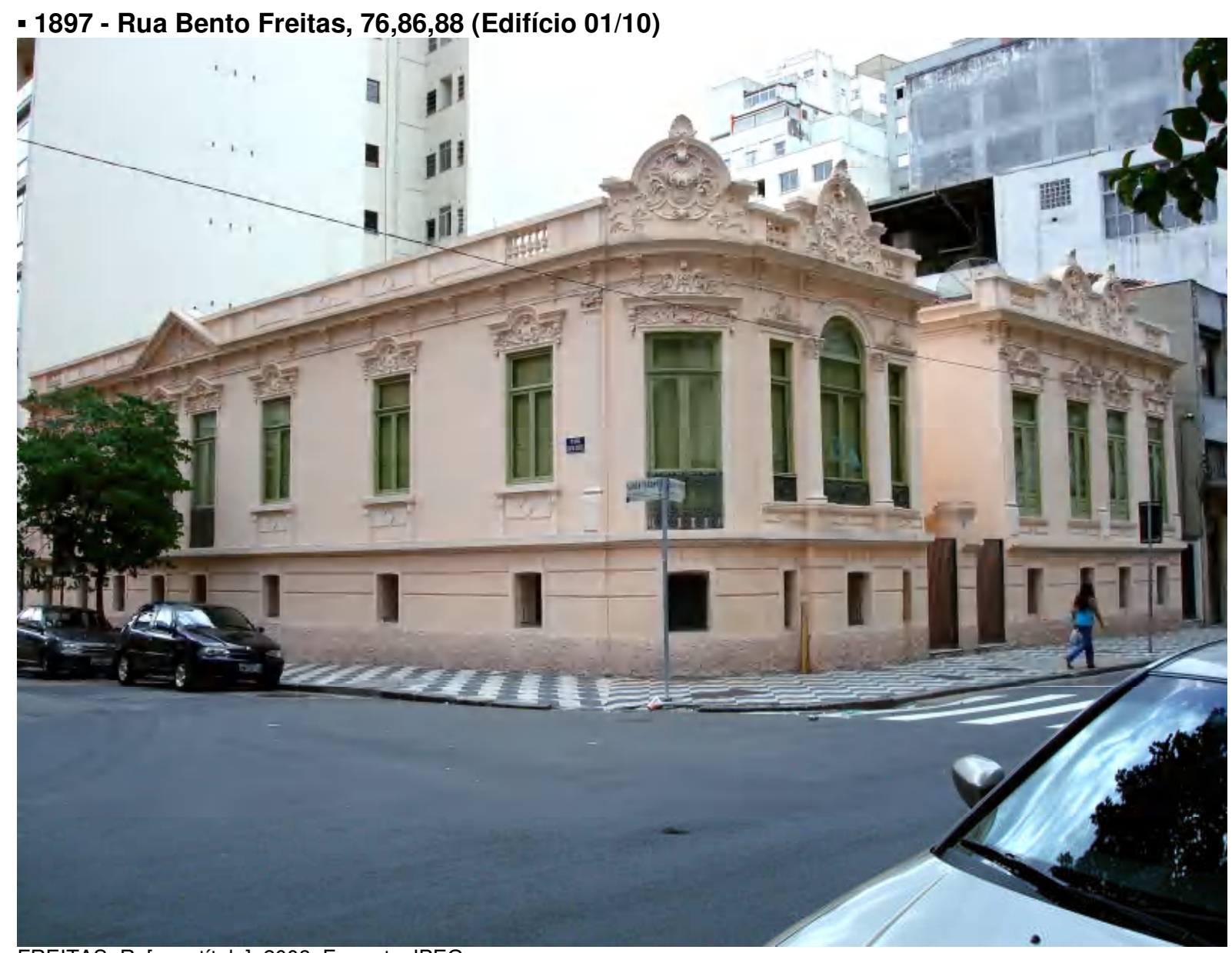

FREITAS, R. [sem título], 2008. Formato JPEG

Tombadas em 1994 e hoje restauradas, estas casas construídas para aluguel na Vila Buarque são de alvenaria de tijolos, com pisos e forros de madeira. As fachadas, que seguem o padrão municipal, são tratadas com platibandas ornamentadas e janelas com frontões triangulares e curvos. Configura-se como importante exemplar ao refletir a legislação edilícia vigente nos primeiros 15 anos do século $X X$.

Vale ainda ressaltar, que a edificação é chanfrada na esquina, exigência que foi verificada nesta pesquisa a partir de 1912, na Lei no 1.585 . Como a edificação foi construída 15 anos antes da lei de 1912, entende-se que tal exigência existia, apesar de não ter sido explicitada no Código de Posturas do Município de 1886, pois 
lê-se no código de 1886 que compulsoriamente deveria edificar-se no alinhamento frontal do lote, sob pena de multa, demolição da irregularidade e/ou prisão do mestre de obras por 8 dias. Conforme explicitado na lei, este alinhamento era definido por fiscal e engenheiro da Câmara do Município de São Paulo. Partindo-se destas constatações, entende-se que o chanfro foi definido pelo arruador, representante da câmara, que aplicava as regras de arruamento e alinhamento dos edifícios, apesar destas regras não estarem explicitadas na íntegra no código de 1886.

A imagem abaixo reproduz, em escala reduzida, um projeto de reforma da edificação existente em 1907 à Rua São Bento, antigo no 50. Vale lembrar que não corresponde à atual numeração da rua e por isso não há fotografia da edificação, que não foi encontrada seguindo-se os critérios de fachadas que resultariam do corte ilustrado abaixo. Este projeto do Escritório Técnico Samuel e Christiano das Neves, que mostra uma edificação já existente a ser reformada, exemplifica como eram utilizados os lotes do "centro" de São Paulo no início do século XX, isto é, em todos os seus limites, com iluminação natural proveniente de lanternim ou área interna ao lote.

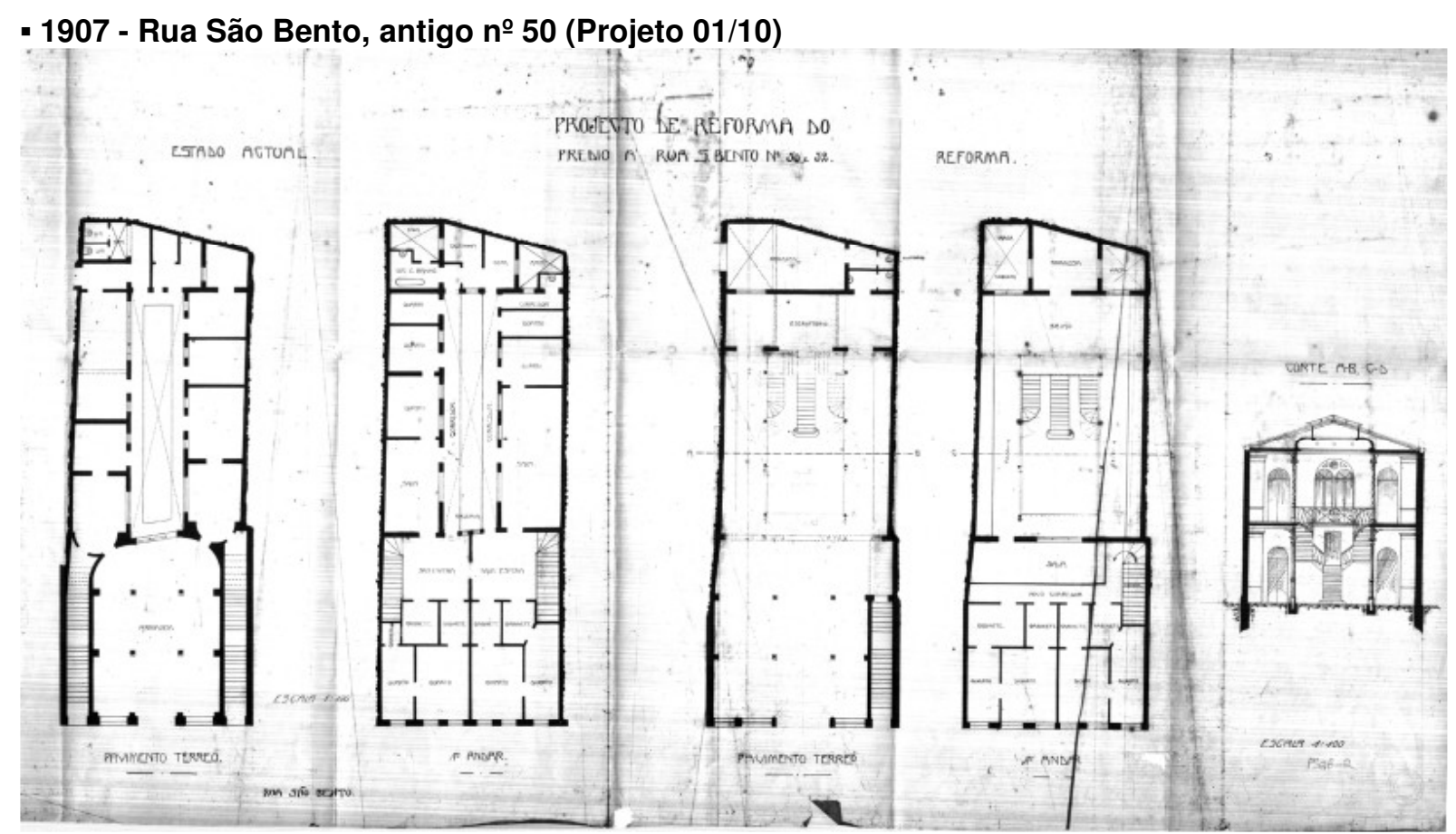

NEVES, S. Plantas e corte transversal do projeto de reforma de edifício à Rua São Bento, antigo no50 - 1907. Folha única. Original em cópia heliográfica. Fonte: Seção de Projetos - Biblioteca FAUUSP, classificação: P N414/725.2 PSAB.

Nota-se pelas plantas acima que a construção original, baseada no tijolo como elemento estrutural, receberia novos pilares metálicos ao centro, sustentando o 
pavimento superior e permitindo a implantação de uma nova escada, que daria acesso as galerias superiores. As alturas mínimas do térreo e primeiro pavimento seguem o Código de Posturas do Município que previa no mínimo 5,00 mais 4,88 metros respectivamente. O soalho, que deveria estar a 0,50 metro do solo não está representado na ilustração abaixo, portanto, entende-se que este projeto estaria em desacordo com a lei neste aspecto. De acordo com o Código Sanitário do Estado São Paulo (1894) esta edificação poderia atender a 80 pessoas, a partir do projeto original, pois tinha 4 bacias sanitárias e de acordo com o critério de cubagem mínima de ar - $14 \mathrm{~m}^{3}$ por pessoa - teria condições de atender a mais de 100 pessoas.

O projeto reproduzido a seguir, com suas plantas, elevações e corte - em escala reduzida - foi realizado por Samuel das Neves para um prédio de propriedade da Companhia de Calçados Clark Ltda.

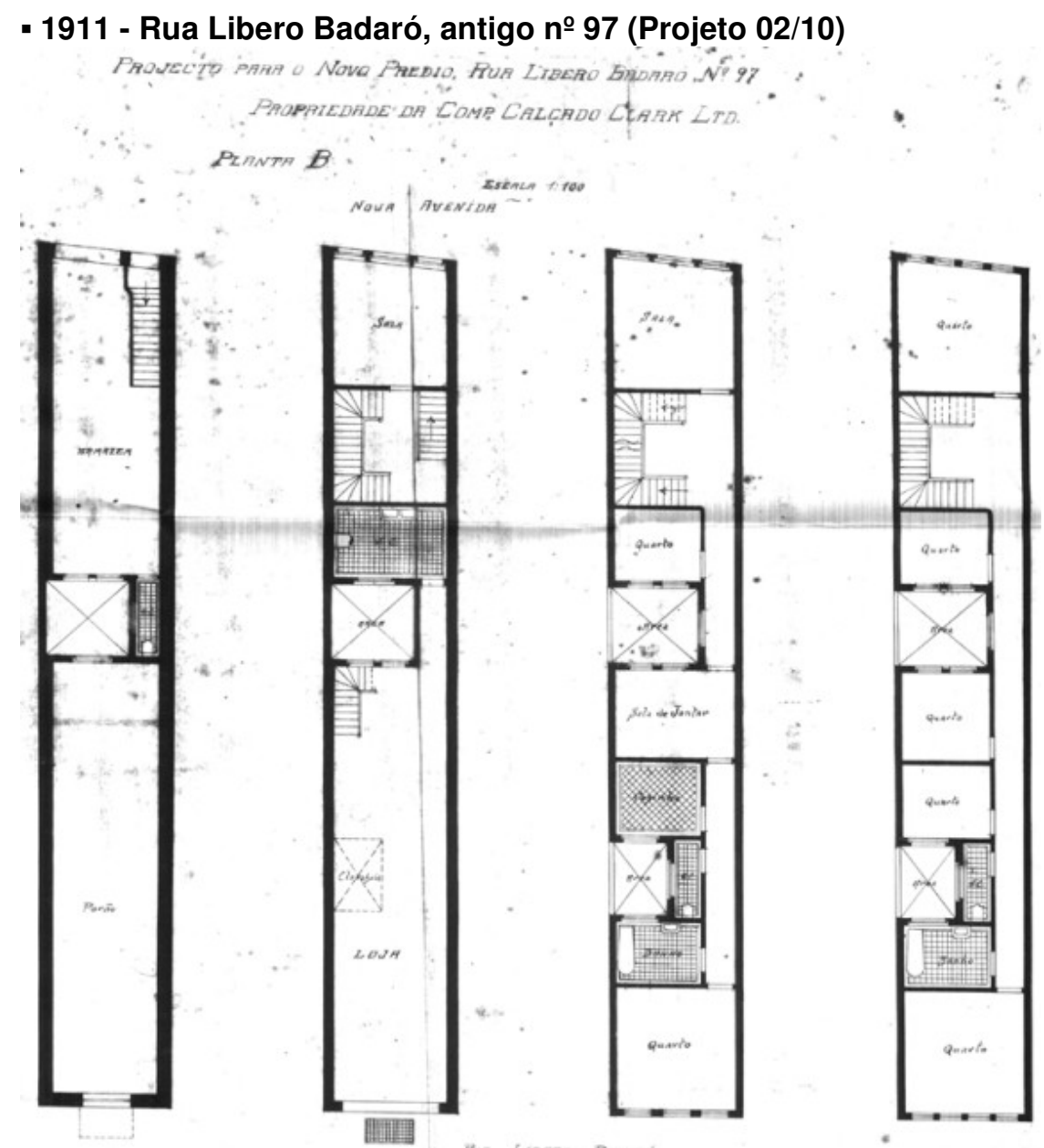


Seguindo-se as fachadas definidas em projeto, não foi possível localizar o antigo no 97 na atual configuração da via, com nova numeração. Deste modo, toma-se o projeto, sem a obra, para análise da aplicação das leis edilícias em meados da primeira década do século XX. As janelas seguem as proporções exigidas pela lei e as fachadas seguem o Padrão Municipal. Comparando-se as elevações encontradas ao corte longitudinal do edifício, verifica-se que uma delas tem térreo e mais dois pavimentos, sendo que no corte há indicação da Rua Líbero Badaró para esta elevação menor. Entende-se que tal edifício teria seus fundos voltados para o Vale do Anhangabaú, para a Avenida Nova, conforme indicado no corte. Esta segunda fachada teria térreo e mais três pavimentos. A ocupação do lote seria sem recuos, ventilando-se os ambientes através de área interna, conforme previa a legislação.

- 1911 - Rua Libero Badaró, antigo no 97 (Projeto 02/10)

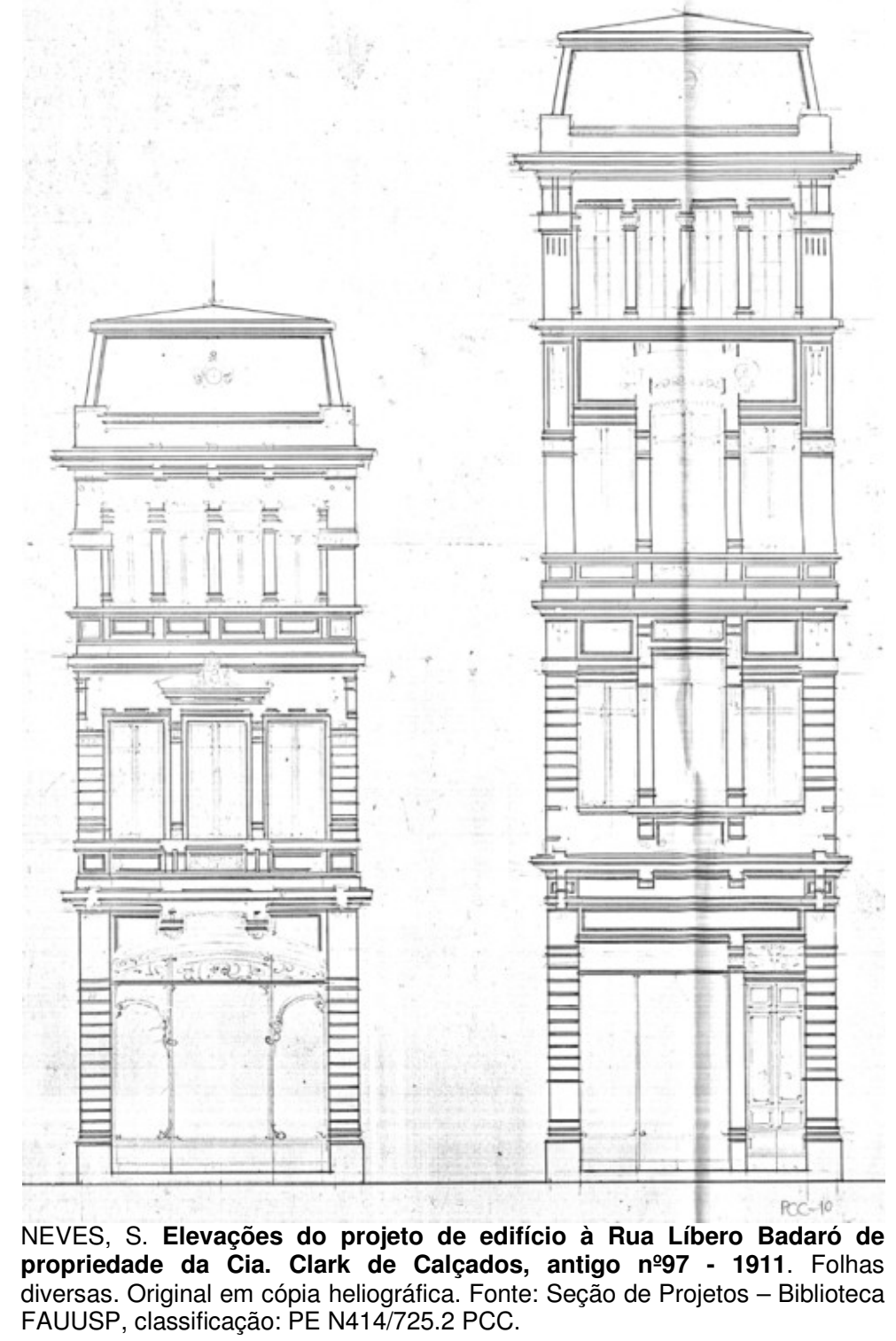


Analisando-se as plantas deste projeto à Rua Líbero Badaró, verifica-se que a taxa de ocupação do lote é de mais de $90 \%$, tendo em vista que no porão (planta mais à esquerda) há a projeção não ocupada da área de ventilação e iluminação interna ao lote. De acordo com a Lei no 498 de 1900, toda edificação deveria ter uma área aberta interna compulsória de no mínimo $10 \mathrm{~m}^{2}$, com o lado menor de no mínimo 2 metros de comprimento. Porém, verifica-se neste projeto que a área de ventilação e iluminação foi dividida em duas, contemplando o critério mínimo de área, mas não o da face menor desta área (uma aresta maior ou igual a 2 metros). O corte abaixo evidencia que este projeto seguia o critério técnico estabelecido pela Lei no 38 de 1893, pois percebe-se que a parede do último pavimento tem espessura mínima de $30 \mathrm{~cm}$, sendo que a cada pavimento subseqüente, de cima para baixo, há um engrossamento obrigatório de $15 \mathrm{~cm}$. Este projeto está de acordo com o Código Sanitário do Estado de São Paulo de 1894, que definia no mínimo 4 metros de altura para todos os pés-direitos, pois os pés-direitos dos pavimentos têm respectivamente do térreo da Rua Líbero Badaró para cima: 5,0m; 4,4m; 4,2m. Entende-se por este corte que não foi obedecido o critério de espaçamento mínimo de $50 \mathrm{~cm}$ entre o solo e o pavimento de entrada através de uma soalho, como previa a lei vigente.

- 1911 - Rua Libero Badaró, antigo no 97 (Projeto 02/10)

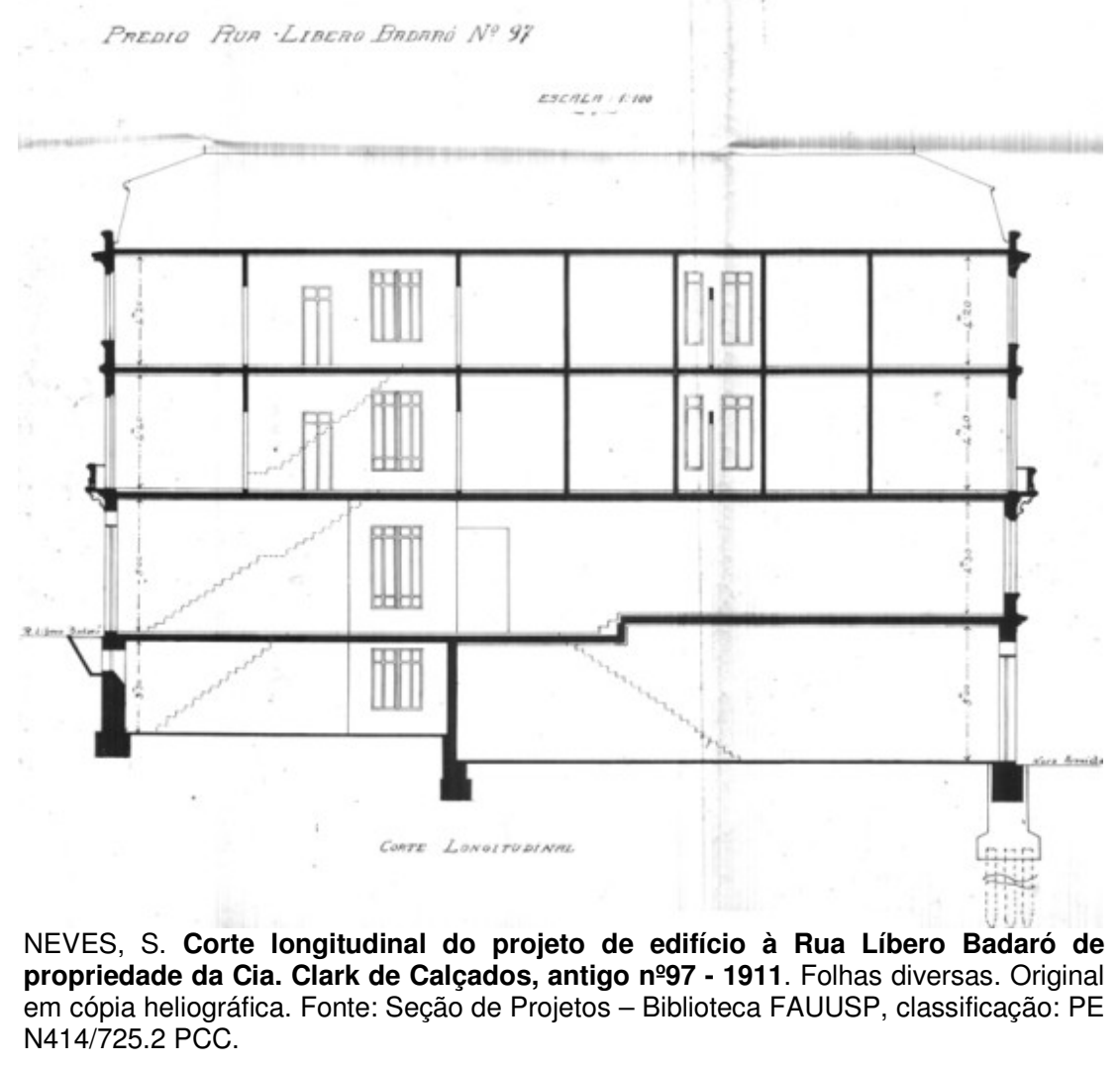




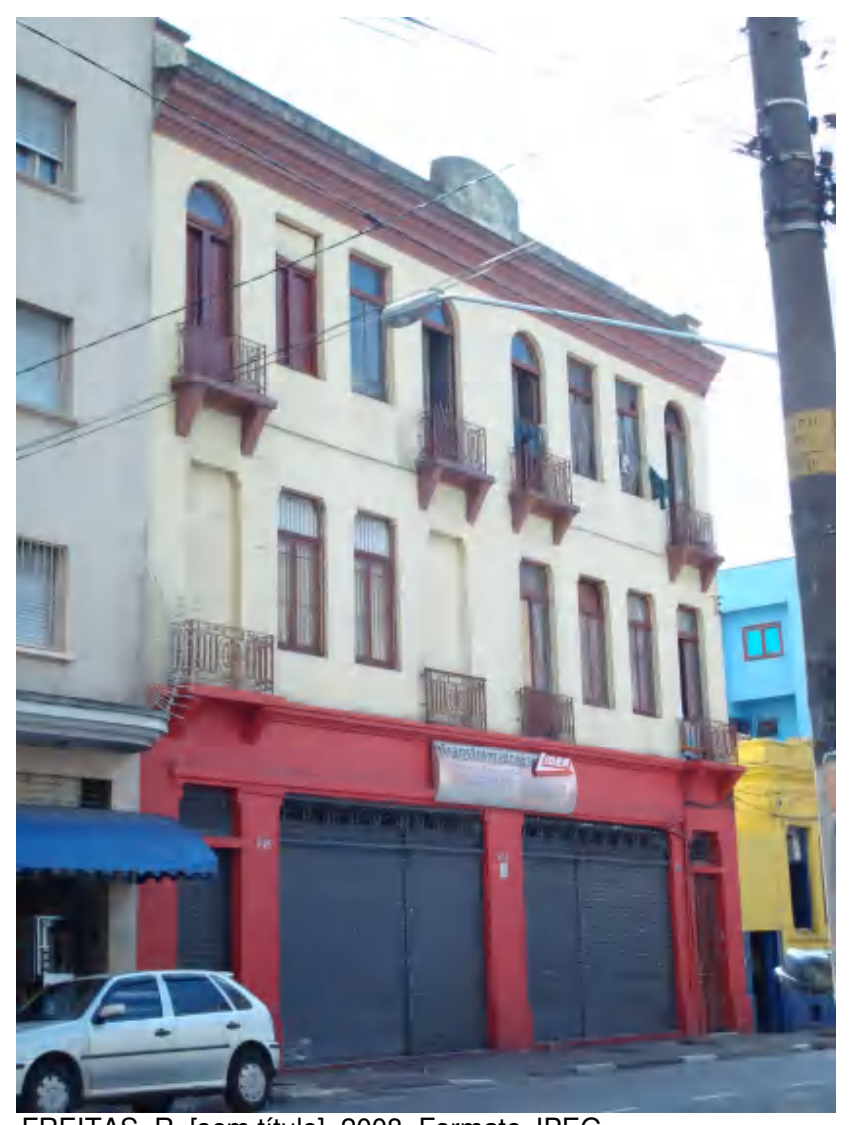

FREITAS, R. [sem título], 2008. Formato JPEG

De acordo com o projeto de Samuel das Neves, foi construído à Rua dos Andradas, para o Sr. Rodrigo Monteiro Junqueira, um prédio cuja disposição interna dos ambientes permitiria o uso por quatro famílias distintas. Previu-se a instalação de quatro conjuntos iguais com dois quartos, sala de visitas, sala de jantar, copa, cozinha e sanitário. Não se configurou como os atuais apartamentos, cujos conjuntos são independentes, mas sim como dois grandes módulos independentes, como duas casas geminadas, porém, para cada casa foi construído um programa duplicado, sendo um no primeiro e outro no segundo andar. Considerando-se o critério de cubagem mínima de $\operatorname{ar}\left(14 \mathrm{~m}^{3}\right.$ por pessoa) estabelecido à época pelo Código Sanitário do Estado de São Paulo, cada habitação poderia abrigar até 7 pessoas, resultando em 28 pessoas nas 4 habitações deste lote. No térreo reservouse espaço para duas lojas independentes, cada qual com o seu sanitário. Por motivos desconhecidos a fachada construída não seguiu o detalhamento de projeto, sendo construída de forma bastante simplificada. De acordo com as plantas, a ventilação do conjunto é feita por uma área interna, que serve a todos os ambientes que não estão voltados para a rua, adequando-se à Lei nº 498 de 1900. 
- 1912 - Rua dos Andradas, 492 - 496 (Projeto 03/10)

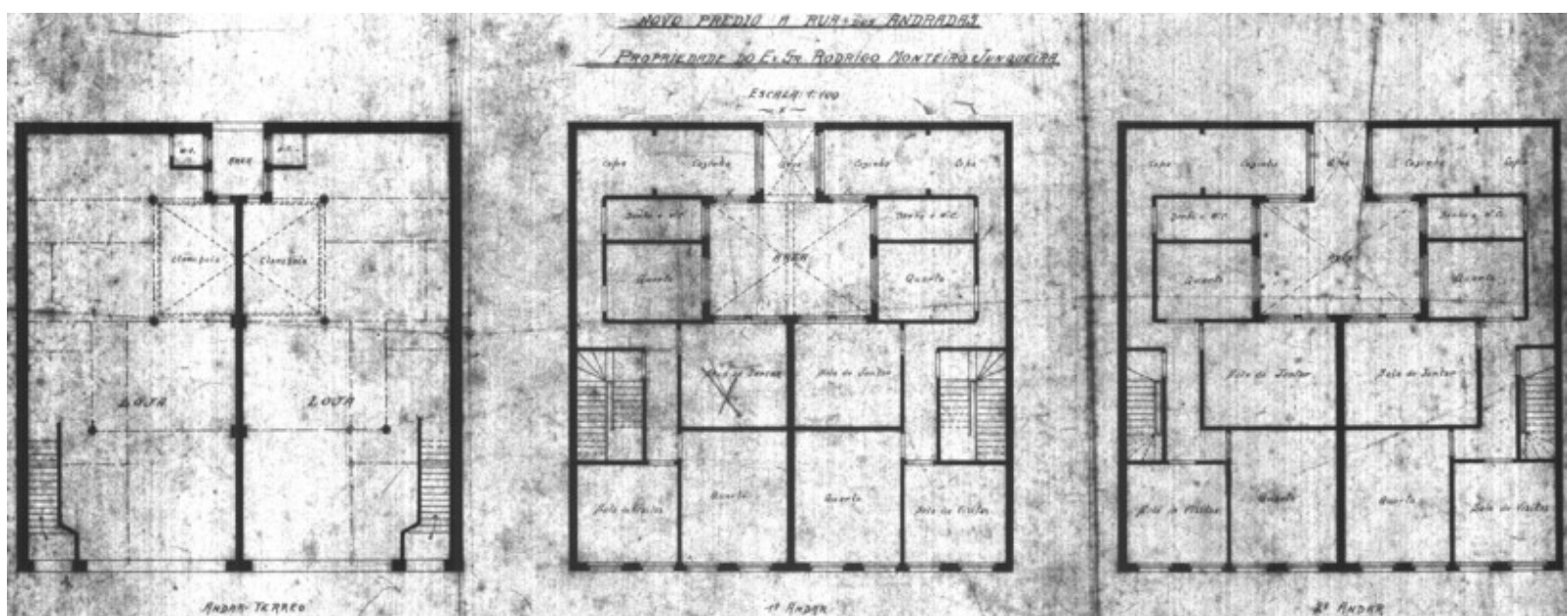

NEVES, S. Plantas do projeto de edifício à Rua dos Andradas de propriedade Rodrigo Monteiro Junqueira, no $492-496$ (antigo no38-44) - 1912. Folhas diversas. Original em cópia heliográfica. Fonte: Seção de Projetos - Biblioteca FAUUSP, classificação: P N414/725.2 PRMJ.

- 1912 - Rua dos Andradas, 492 - 496 (Projeto 03/10)

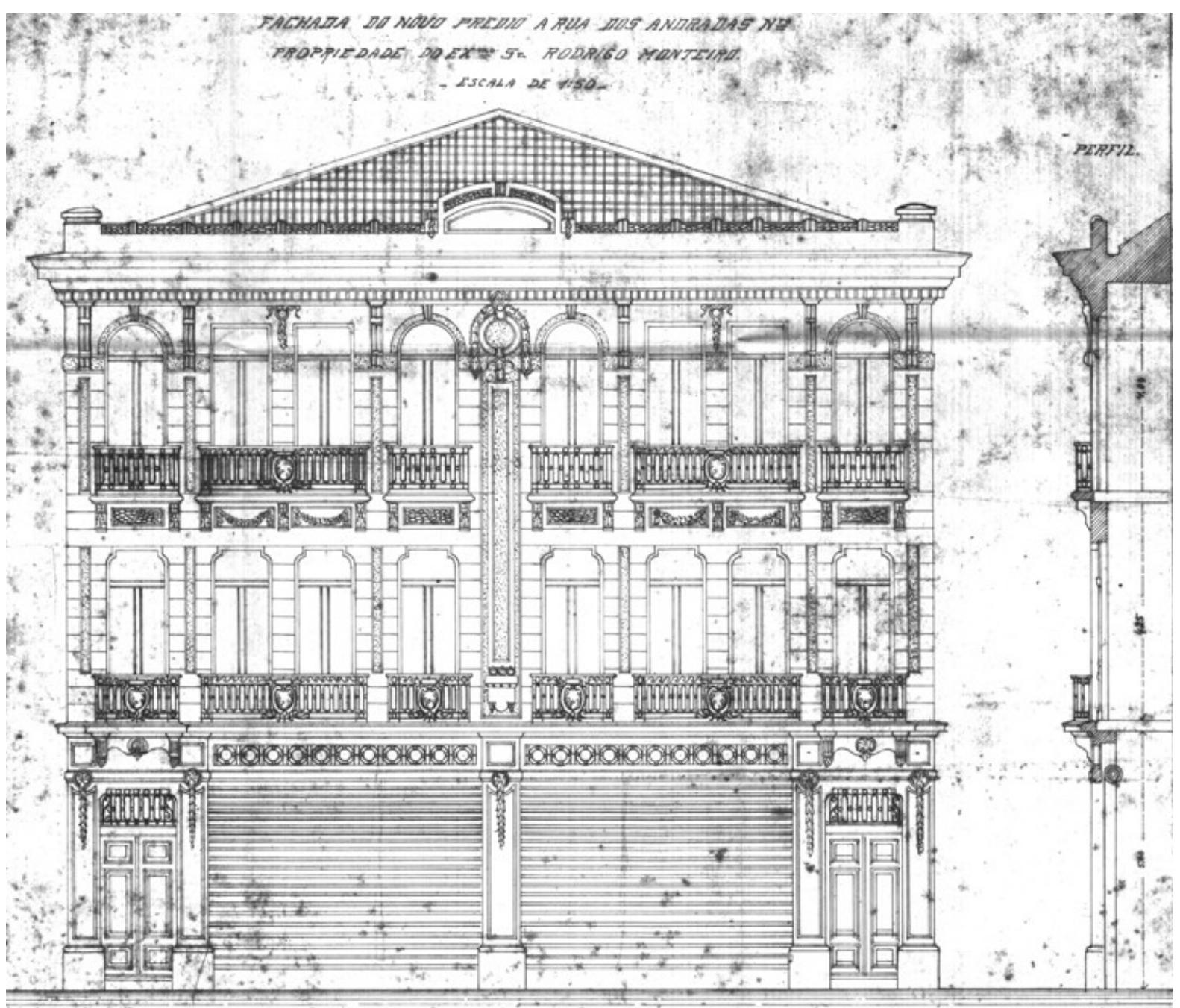

NEVES, S. Elevação do projeto de edifício à Rua dos Andradas de propriedade Rodrigo Monteiro Junqueira, no $492-$ 496 (antigo no38-44) - 1912. Folhas diversas. Original em cópia heliográfica. Fonte: Seção de Projetos - Biblioteca FAUUSP, classificação: P N414/725.2 PRMJ. 
De acordo com REIS (1970), mesmo com a persistência do fachadismo, com poços internos ainda insatisfatórios como solução e com edificações formando blocos construídos, a alteração da paisagem urbana do início do século $X X$ tratava-se claramente de uma transformação radical. A partir deste período, Christiano das Neves teria um importante papel na história do concreto armado e da verticalização de São Paulo. Em 1917, edificou o Prédio Riachuelo à Ladeira Dr. Falcão, esquina com a Rua líbero Badaró. Em 1924 foi construído seu projeto para o prédio Sampaio Moreira, com 14 andares, considerado pelo seu autor o primeiro arranha-céu de São Paulo. O então diretor de obras da prefeitura, Victor da Silva Freire, aprovou o projeto apesar da Lei n 2.322/20 estabelecer que a altura máxima para o edifício não poderia ultrapassar três vezes a largura da rua, quando esta fosse maior do que 12 metros, portanto, 54 metros de altura para a Líbero Badaró, com 18 metros de largura.

- 1924 - Rua Libero Badaró, 344 a 350 (Edifício 03/10)

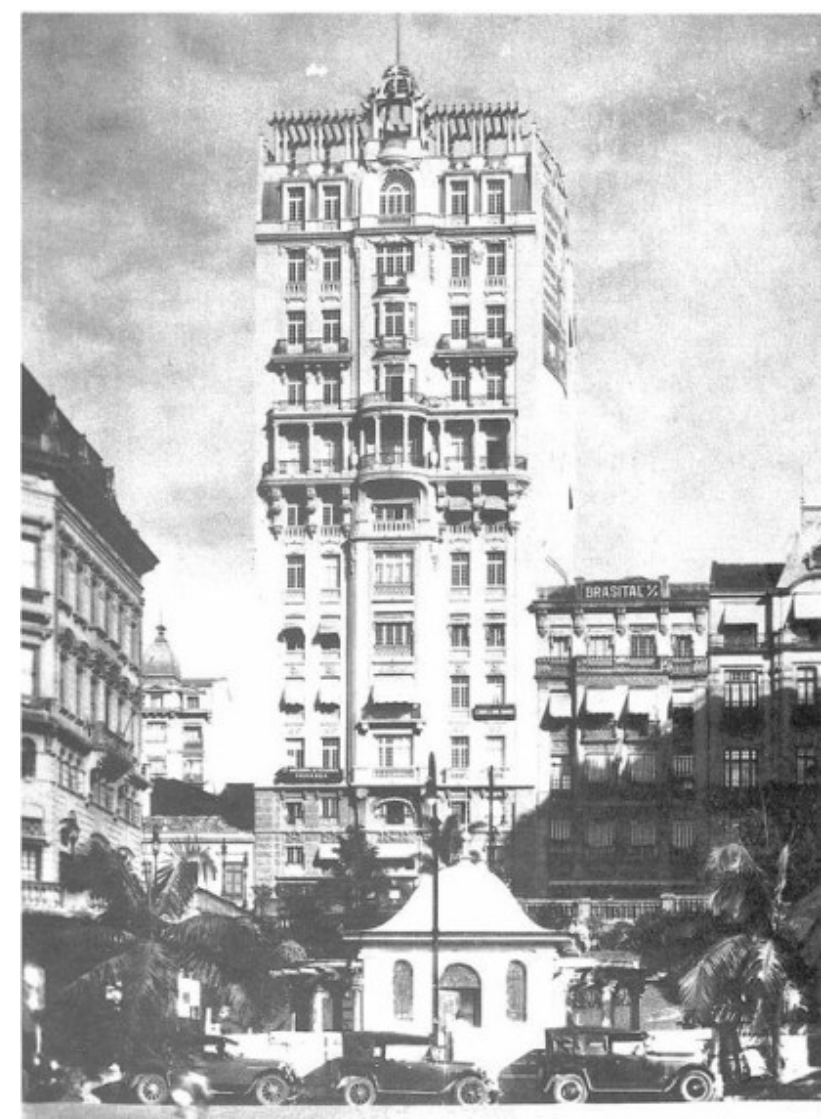

Autor desconhecido. Cartão Postal dos anos 20. Disponível em: <http://www.piratininga.org>. Acesso em: 20 abr. 2007 
- Rua Libero Badaró, 344 a 350

(Edifício 03/10)

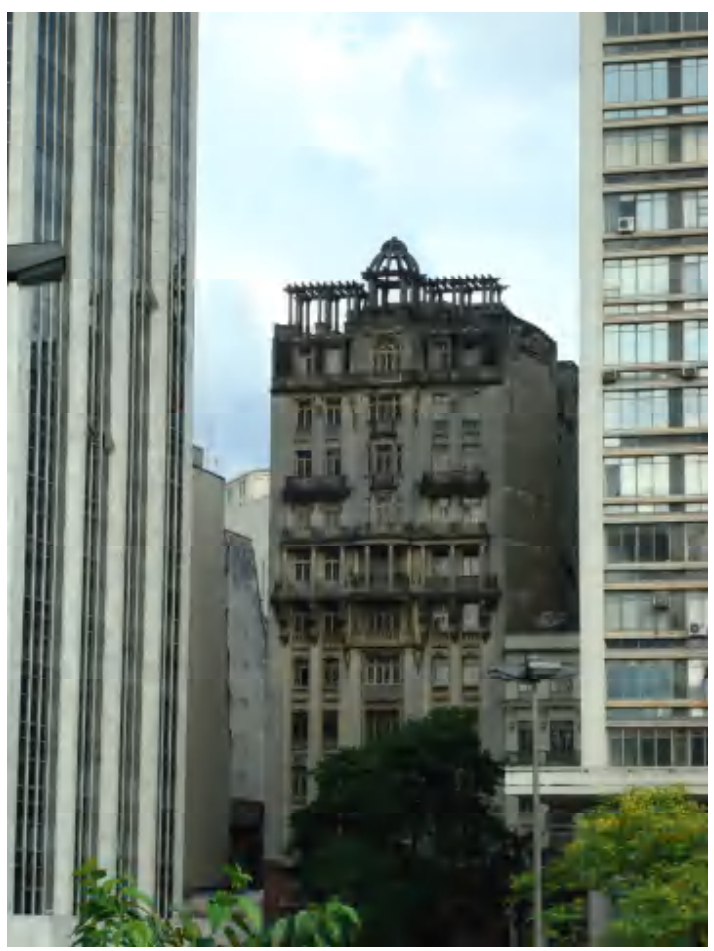

FREITAS, R. [sem título], 2008. Formato JPEG

- Rua Libero Badaró, 344 a 350

(Edifício 03/10)

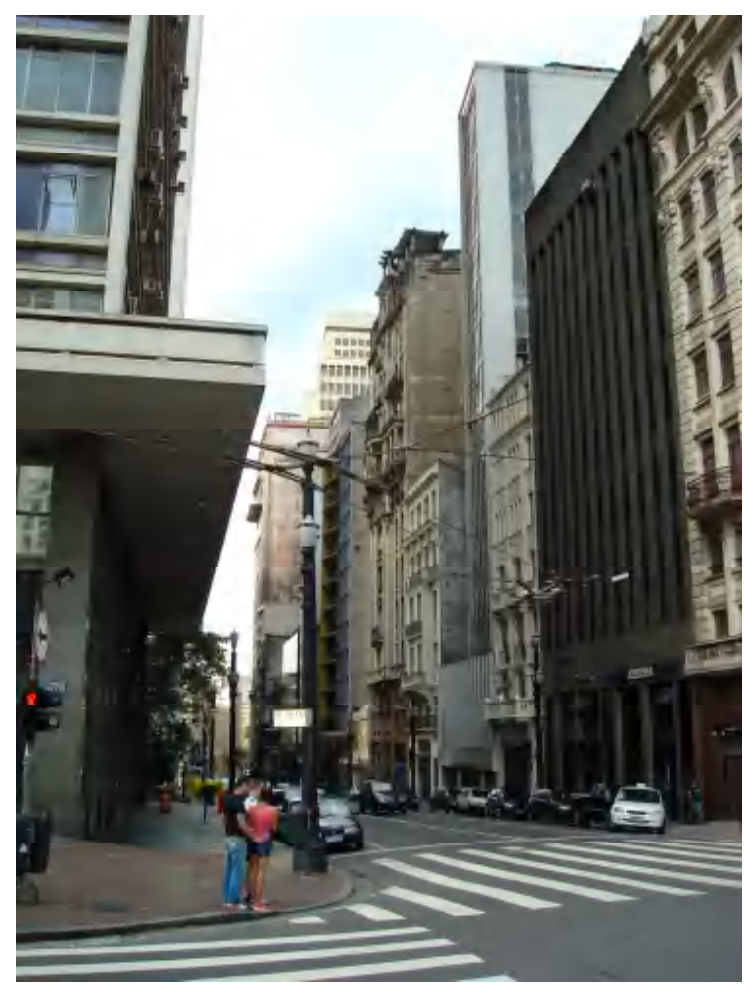

FREITAS, R. [sem título], 2008. Formato JPEG
Verifica-se na foto da página anterior, que a edificação lindeira ao edifício Sampaio Moreira, à sua esquerda é contemporânea a ele e tem térreo mais cinco pavimentos. À sua direita, o prédio com térreo mais um pavimento foi construído antes da Lei no 2332 de 1920, que exigia nesta via construções com térreo mais quatro pavimentos no mínimo. Entende-se pelas imagens desta página que o espaço urbano neste trecho da cidade foi cristalizado em função da sobreposição e descontinuidade dos critérios legais, conforme explicitado nos capítulos 4 e 5.

Em 1924 vigorava o padrão municipal de fachadas, base para avaliação de projetos encaminhados à comissão de estética da prefeitura. Verifica-se nas páginas seguintes, com a reprodução do projeto de Christiano das Neves, que à fachada frontal foram dedicadas muitas horas de trabalho em projeto. Estas evidências vêem-se nos esmerados detalhes ainda perceptíveis em uma folha já em decomposição em alguns trechos, mas que mesmo reproduzida em escala reduzida representa o nível técnico em que se encontravam os profissionais envolvidos em projetos como este naquele período. 
- 1924 - Rua Libero Badaró, 344, 350 (Projeto 04/10)

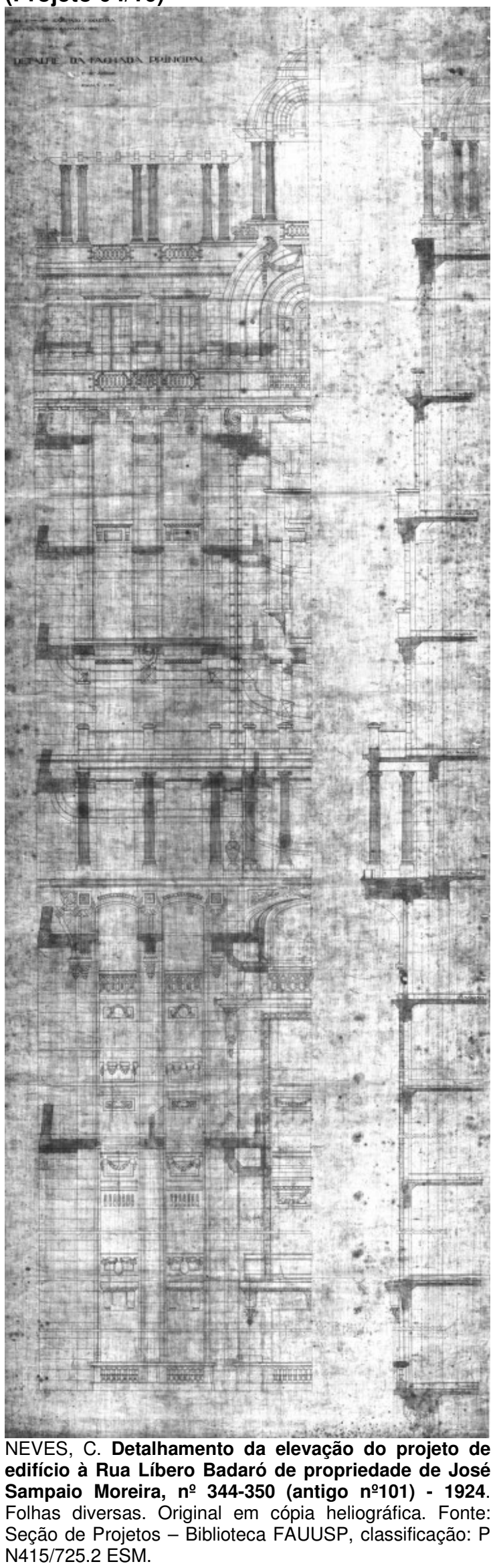

Detalhamento original da fachada em escala 1:20, aqui reproduzido sem escala, como registro da aplicação dos critérios de fachadas previstos na legislação edilícia vigente àquela data, Lei no 2.332 de 1920. Apesar do esforço de projeto para a criação desta fachada principal, verifica-se nas próximas duas páginas, (corte longitudinal do edifício e principais plantas), que ao ser implantado seguindo-se os critérios legais do período, o volume edificado teve solução comum à época sem dar atenção às fachadas laterais. Isto porque faceou todos os limites do terreno, à exceção dos fundos, que de acordo com a lei deveria ter $12 \%$ de área livre. Nesta área livre podia-se instalar sanitários, conforme a lei. Sendo assim, a solução final de projeto previa a instalação de quatro bacias sanitárias ao nível do térreo na área dos fundos, conforme planta reproduzida a seguir. Porém, além de ser um edifício ilegal em função da altura, este edifício não seguiu o critério de corredor para ventilação lateral do Ato no 900 de 1916, assim como não respeitou a proporção do pátio interno de ventilação e iluminação estabelecido pela Lei $n^{-}$ 2.332 de 1920, conforme interpretação gráfica exposta no capítulo 4 . 
- 1924 - Rua Libero Badaró, 344, 350 (Projeto 04/10)

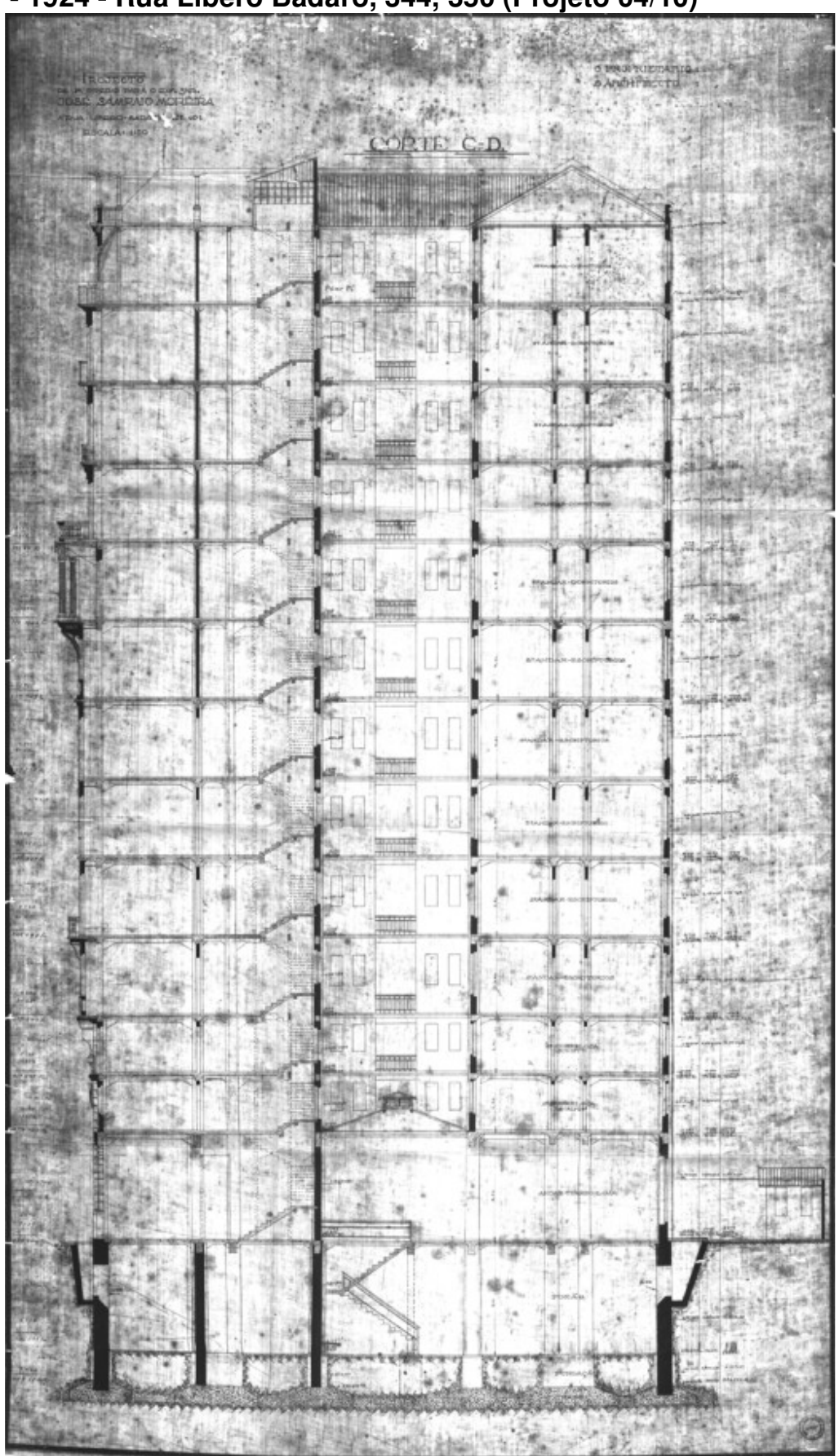

NEVES, C. Corte longitudinal do projeto de edifício à Rua Líbero Badaró de propriedade de José Sampaio Moreira, no 344-350 (antigo no101) - 1924.

Folhas diversas. Original em cópia heliográfica. Fonte: Seção de Projetos Biblioteca FAUUSP, classificação: P N415/725.2 ESM.

Este corte evidencia a escada que liga o térreo ao telhado do edifício, critério estabelecido para edifícios com mais de 5 pavimentos, pela Lei № 2.332 de 1920. Nota-se que o critério desta lei para engrossamento das paredes a cada pavimento, uma adequação da Lei ํo 38 de 1893, não se aplica aos edifícios construídos em concreto armado, deste período em diante. 
- 1924 - Rua Libero Badaró, 344, 350 (Projeto 04/10)

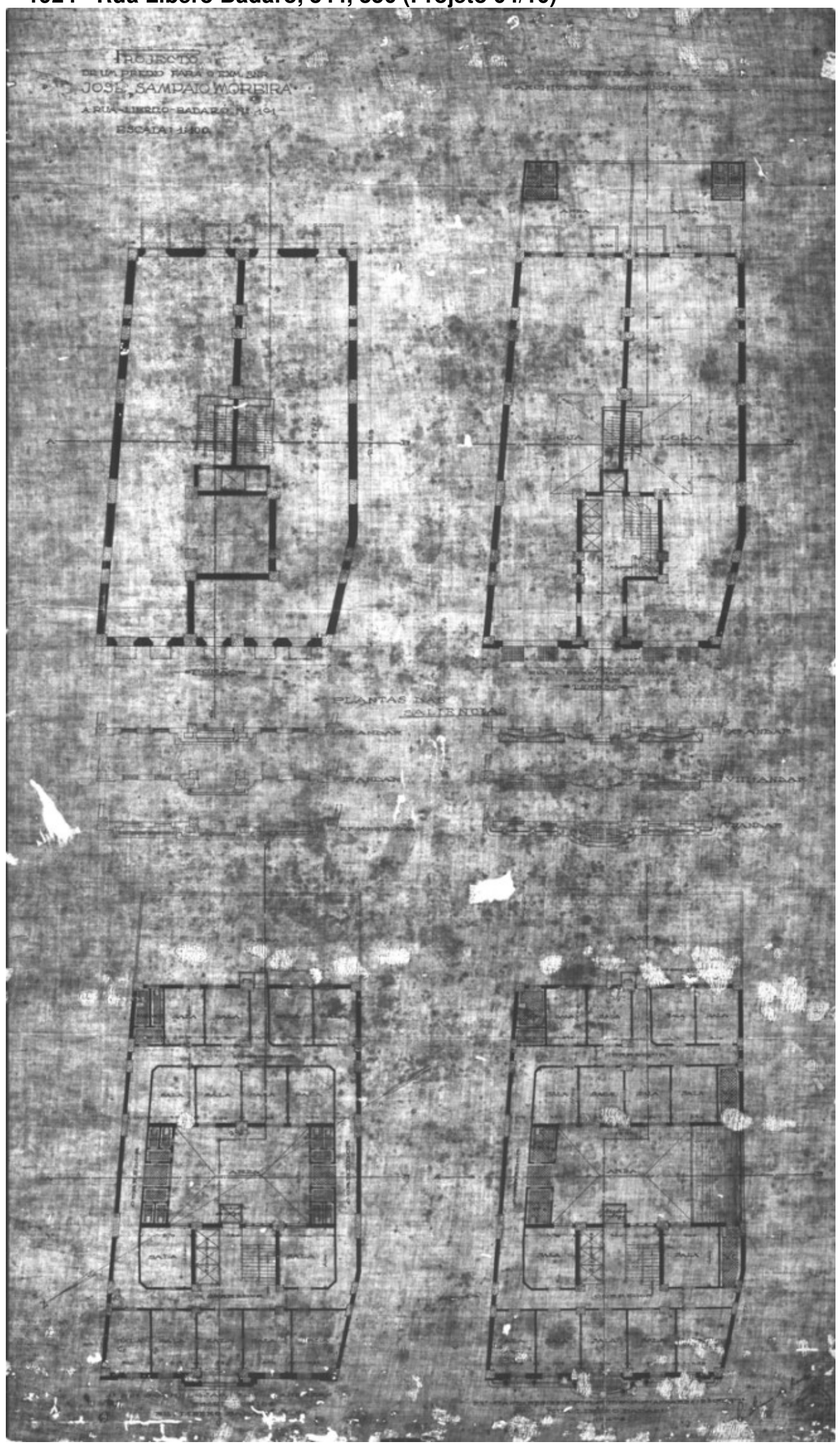

NEVES, C. Plantas do projeto de edifício à Rua Líbero Badaró de propriedade de José Sampaio

Moreira, no 344-350 (antigo no101) - 1924. Folhas diversas. Original em cópia heliográfica. Fonte:

Seção de Projetos - Biblioteca FAUUSP, classificação: P N415/725.2 ESM. 


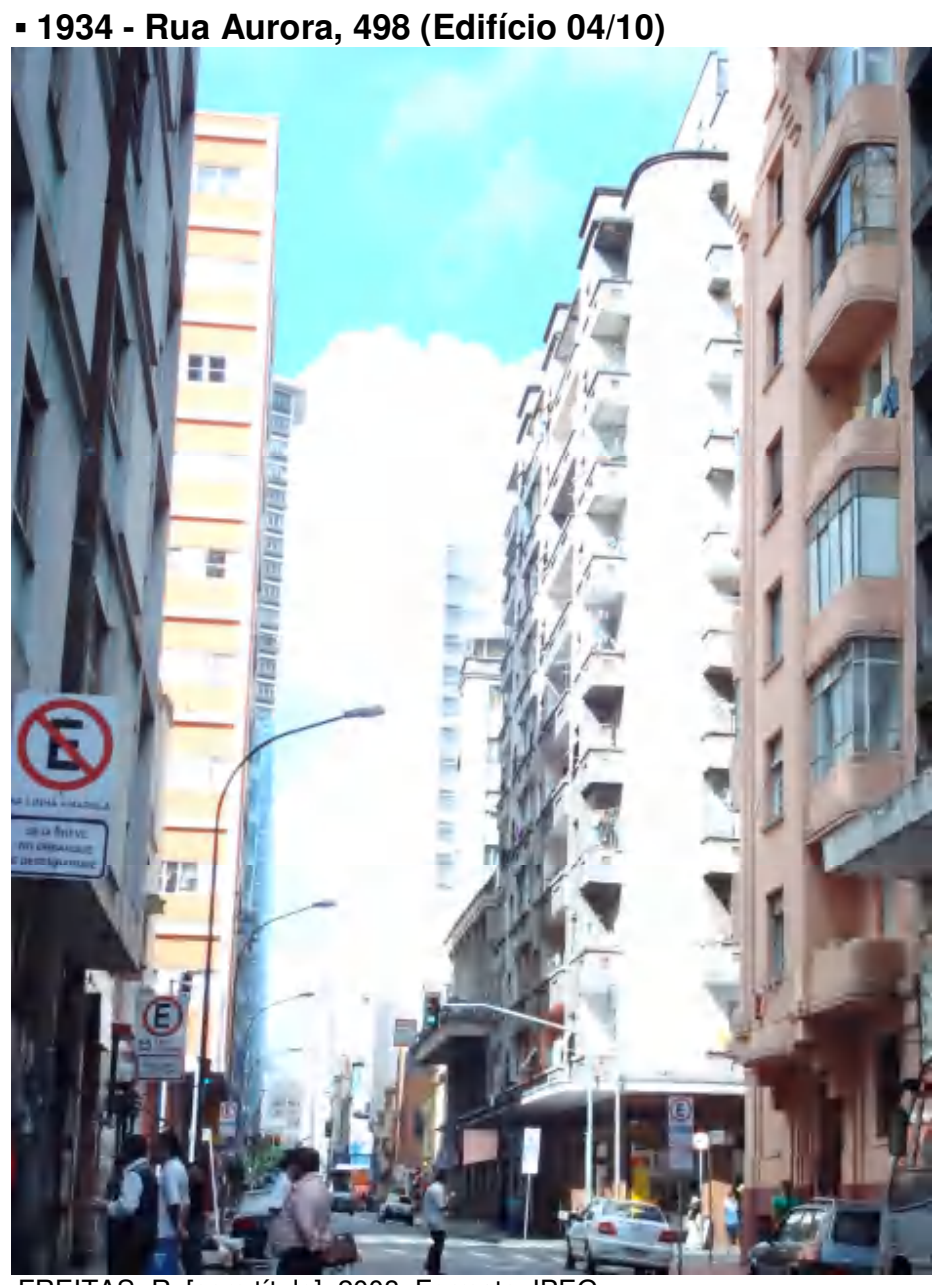

FREITAS, R. [sem título], 2008. Formato JPEG

O edifício projetado pelo Escritório Técnico "Ramos de Azevedo" Severo \& Villares para o senhor Antonio Barros previa na esquina da Rua Guaianazes com Rua Aurora um edifício para renda (à direita da foto acima, edifício com pequena marquise em toda a volta do lote). No térreo previram-se 9 lojas independentes, cada qual com seu sanitário, e um conjunto com quarto, cozinha e sanitário, possivelmente para a pessoa responsável por zelar pelo edifício. O pavimento tipo contava com três cozinhas, 12 quartos, 1 sala, 2 pequenos ambientes sem uso especificado, 2 suítes e 5 sanitários, com 3 terraços, dois elevadores, 1 escada e 2 espaços definidos como espaços de "luz", para iluminação dos corredores internos. Assim como na edificação da Rua dos Andradas, ilustrada nas páginas anteriores, 0 projeto deste edifício não previa a separação dos ambientes conforme o agrupamento comum aos dias de hoje. Ou seja, não há a caracterização de um apartamento ao qual se entra para então visualizar os demais ambientes. Verificouse que quartos e suítes poderiam ser alugados separadamente, sendo que as cozinhas estavam distribuídas no pavimento de modo a atender todos os cômodos. 
Supõe-se que as cozinhas poderiam ser utilizadas por inquilinos dos cômodos mais próximos a elas. Já a única sala, em função da localização e do acesso possibilitado por duas portas, deveria ser espaço comum a todos os inquilinos, cujo uso seria supostamente organizado por estes. De acordo com a legislação urbana municipal de 1894, que adotou o Código Sanitário do Estado de São Paulo como referência, cortiços eram proibidos desde o fim do século XIX. Conforme o Código de Posturas do Município de 1886, cortiços eram conjuntos de cômodos com área mínima de 5 $\mathrm{m}^{2}$, com uma porta e uma janela, aos quais se destinavam áreas comuns (sanitários, cozinhas e lavanderias) uniformemente distribuídas pelo pátio, no fundo das construções principais dos lotes. Pode-se verificar pelo programa original deste edifício que, passados mais de trinta anos da proibição de cortiços, ainda estavam presentes conceitos similares aos de cortiços na distribuição e utilização de ambientes nas edificações. O conceito de uso do solo urbano mantinha-se até 1934 muito próximo ao conceito do século XIX de utilização do lote para renda. De acordo com a legislação vigente, o Código de Obras Arthur Saboya, o projeto original deste edifício caracterizou-se como "para habitação", seguindo critérios legais de iluminação, circulação interna e dimensionamento de cômodos. Entende-se que o edifício da página anterior foi construído de acordo com a lei.

Têm-se na próxima página uma obra das obras que esteve sob responsabilidade de Jacques Pilon, à Avenida Ipiranga n 871, o edifício Adma Jafet. Composto de um subsolo para depósito, galeria no térreo, 4 sobre-lojas e mais 11 andares, o projeto deste edifício contemplou 88 salas comerciais e 11 salões, sendo estes últimos localizados em um apêndice do terreno, nos fundos do edifício à sua esquerda (ver imagens a seguir).

Nota-se que de acordo com o Decreto-Lei no 41 de 1940 as obras construídas nesta avenida deveriam ter altura mínima de 39 metros, com fachadas contíguas, portanto, com empenas cegas laterais alcançando a altura mínima compulsória da edificação, podendo crescer em altura desde que recuando-se 2,5 metros do alinhamento frontal e ocupando apenas $50 \%$ do lote a partir da altura mínima obrigatória. Vê-se na imagem abaixo que a obrigatoriedade de construção com gabarito mínimo, sob pena de aumento de $20 \%$ no imposto predial dos lotes desta avenida, surtiu efeito quando se analisa a uniformidade dos volumes edificados. 
- 1945 - Avenida Ipiranga, 871 (Edifício 05/10)

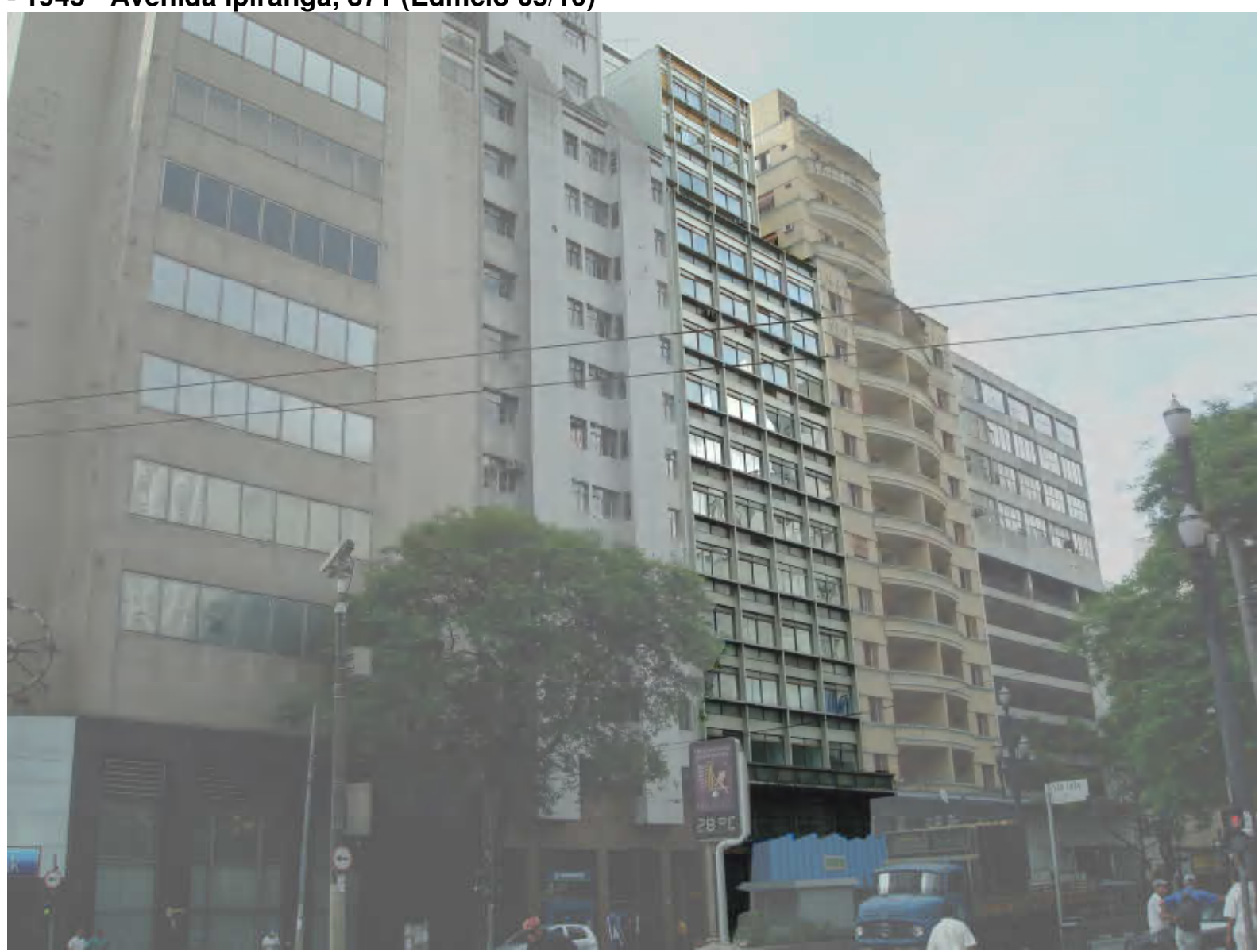

FREITAS, R. [sem título], 2008. Formato JPEG

Nas próximas páginas reproduz-se o projeto deste edifício em escala reduzida. $\mathrm{O}$ corte a seguir, em conjunto com a elevação frontal, comprova que foi obedecido o recuo frontal mínimo, a partir do gabarito mínimo estabelecido pelo Decreto-lei oㅡ 41, de 1940,. Nota-se também que sua altura chegou à metade da altura máxima permitida de 115 metros. As plantas dos últimos pavimentos, expostas mais adiante, comprovam que a ocupação acima dos 39 metros de altura não ultrapassa $50 \%$ da área do lote, conforme previsto no decreto. Há três áreas internas ao lote para iluminação e ventilação da edificação. Verifica-se que a proporção da soma destas três áreas respeita a proporção do pátio interno mínimo de ventilação e iluminação estabelecido pela Lei oㅡ 2.332 de 1920, porém, sua configuração com o lado maior equivalente a 1,07 vezes a altura do edifício - não é seguida nesta obra, assim como nos demais projetos analisados nesta pesquisa. O critério de corredor lateral de iluminação e ventilação, previsto no Ato ํํ 900, de 1916, também não foi verificado nos projetos estudados, todos ocupando os limites frontais e laterais dos lotes. 
- 1945 - Avenida Ipiranga, 871 (Projeto 05/10)

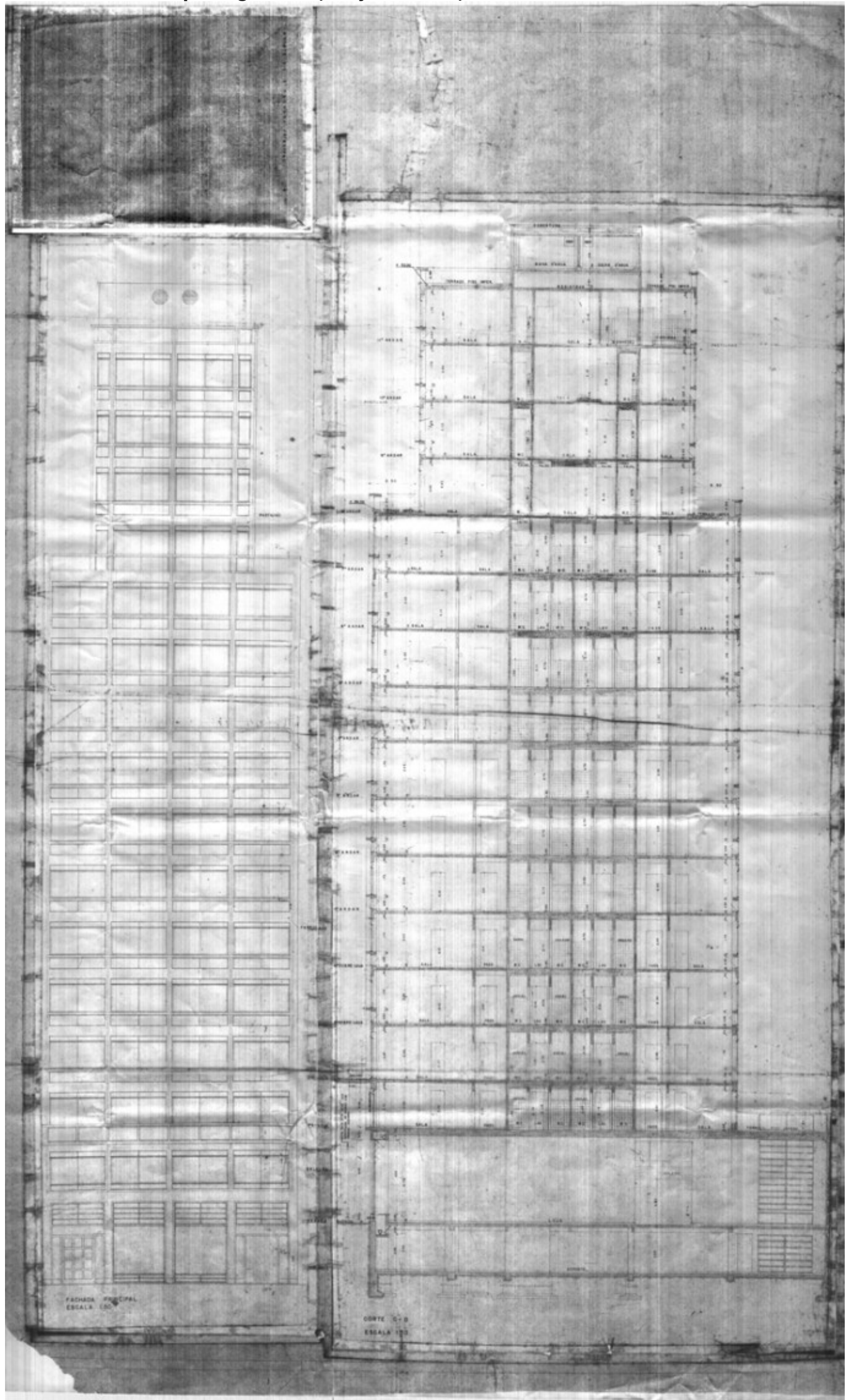

PILON, J. E. P. Elevação e corte longitudinal do projeto de edifício Adma Jafet à Avenida Ipiranga, no871 - 1945. Folhas diversas. Original em cópia heliográfica. Fonte: Seção de Projetos - Biblioteca FAUUSP, classificação: PE P647/725.23 AJ V.1-3. 
- 1945 - Avenida Ipiranga, 871 (Projeto 05/10)

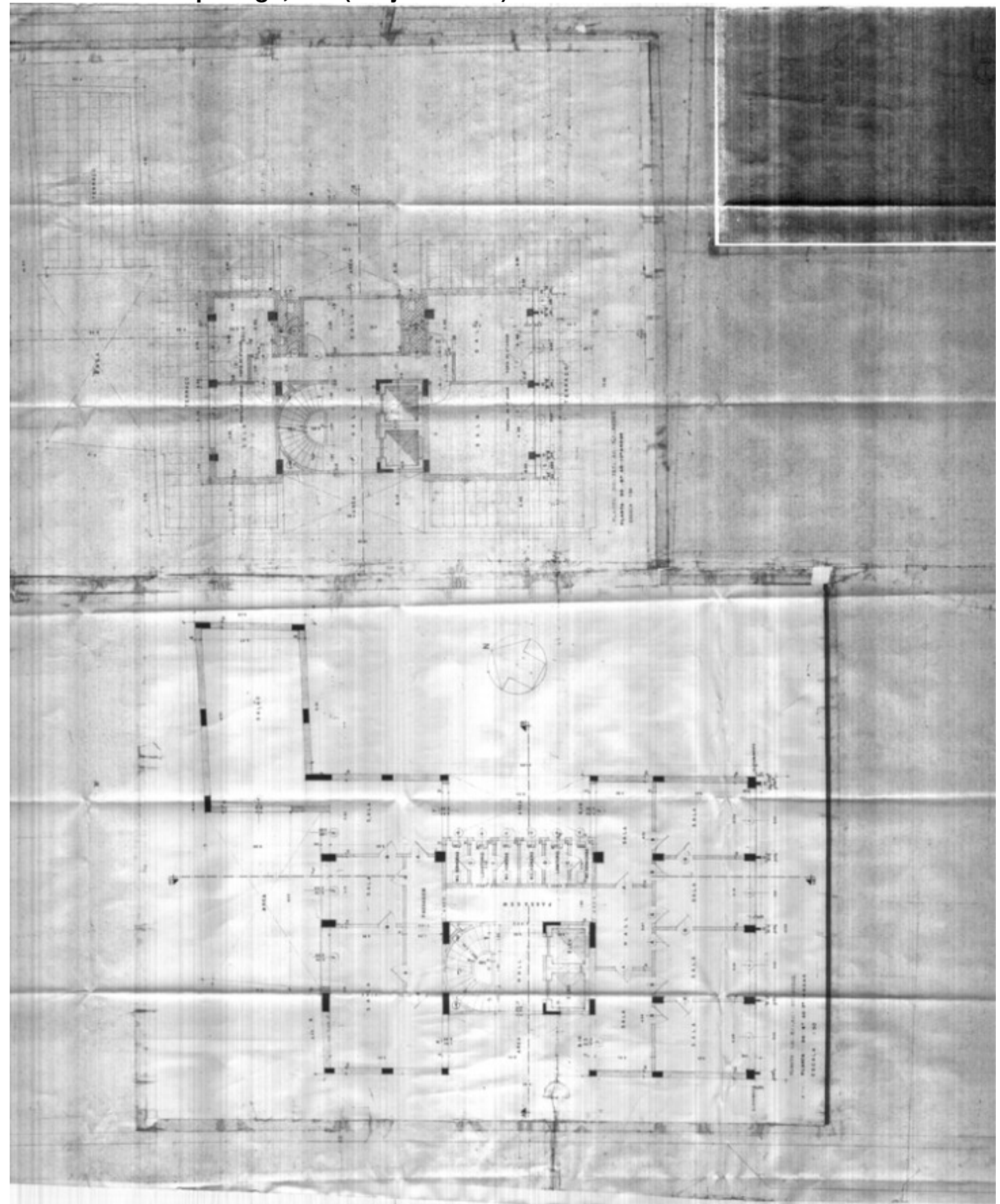

PILON, J. E. P. Plantas do $4^{\circ}$ ao $7^{\circ}$ e do $8^{\circ}$ ao $10^{\circ}$ andar do projeto de edifício Adma Jafet à Avenida Ipiranga, no871 - 1945. Folhas diversas. Original em cópia heliográfica. Fonte: Seção de Projetos - Biblioteca FAUUSP, classificação: PE P647/725.23 AJ V.1-3.

Em função das plantas e cortes analisados, a taxa de ocupação desta edificação excede $80 \%$ da área do lote e seu coeficiente de aproveitamento chega a 10 vezes. O Ato no 663 , de 1934, previa que a taxa de ocupação da edificação principal deveria corresponder a 1/3 da área do lote, que poderia ter outra edificação além da principal. Não se percebe a aplicação deste critério nos projetos analisados nesta pesquisa. Vale ressaltar que este limite de $1 / 3$ não é claro, pois não se sabe, de acordo com o texto da lei, qual a proporção à qual estaria limitada a construção que 
não seria a principal do lote. Quanto ao coeficiente de aproveitamento desta obra, não há incoerência com a legislação, que até 1957 não estabeleceu este tipo de limite no "centro" de São Paulo.

Sob encomenda do Banco Paulista do Comércio S.A., Rino Levi projetou em 1947 um edifício à Rua Boa Vista, esquina com a Ladeira Porto Geral com 15 pavimentos, totalizando $12.387 \mathrm{~m}^{2}$. Edificada em um lote de formato irregular, esta obra alinhouse em planta aos limites do terreno. Em função do Ato n 23, de 22 de dezembro de 1930, que aprovou o projeto de alargamento da Ladeira Porto Geral, a fachada do edifício nesta ladeira foi recuada a partir dos 20 metros de altura, respeitando uma linha que, em corte, ligava este limite de altura ao lado oposto da ladeira, com 10 metros de largura, conforme corte reproduzido nas páginas seguintes.

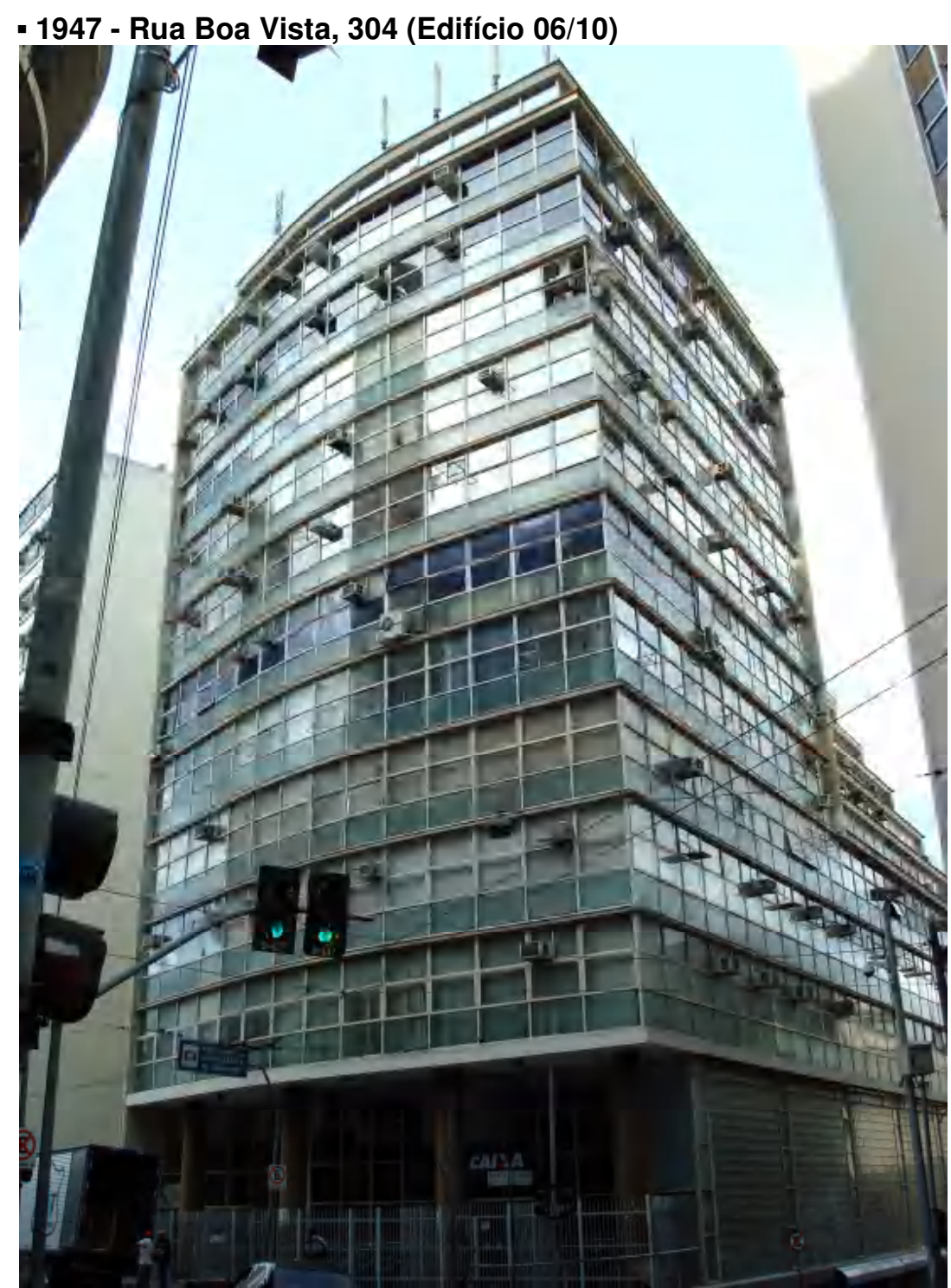

FREITAS, R. [sem título], 2008. Formato JPEG 


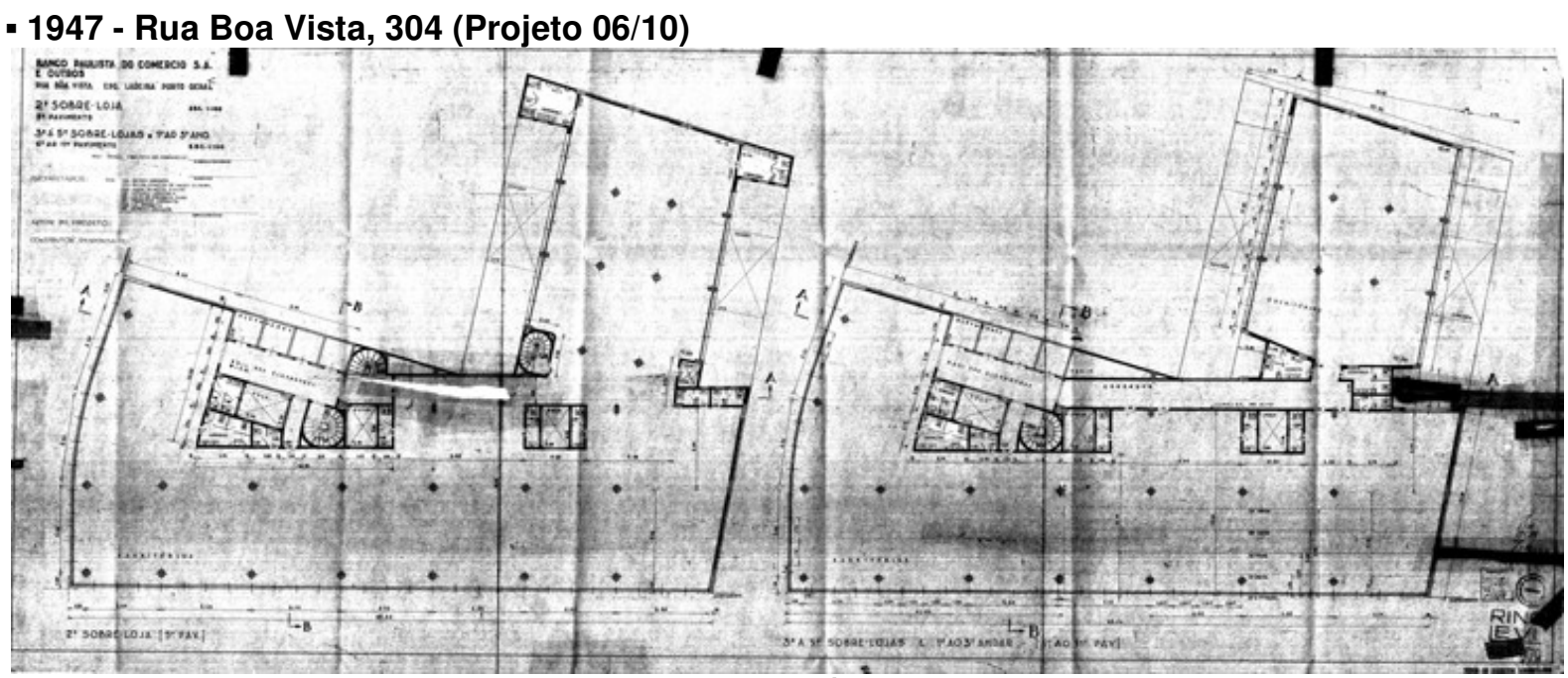

LEVI, R. Plantas 5o e 6 ao 11 pavimento do projeto do edifício Porto Geral de propriedade do Banco Paulista do Comercio S/A., à Rua Boa Vista, esquina com a Ladeira Porto Geral - 1947. Folhas diversas. Original em cópia heliográfica. Fonte: Seção de Projetos - Biblioteca FAUUSP, classificação: PE L578/725.24 BP V.1-7.

De acordo com as plantas expostas acima, foram criados poços mínimos de ventilação e iluminação para áreas de apoio como sanitários e copas. Os demais ambientes são iluminados e ventilados principalmente em função das grades fachadas nos alinhamentos da Rua Boa Vista e Ladeira Porto Geral, sendo que os ambientes internos, localizados no "apêndice" superior das plantas expostas acima, ligam-se a dois grandes pátios, que somados chegam a proporção próxima à estabelecida pela Lei ํㅡㄴ 2.332 de 1920.

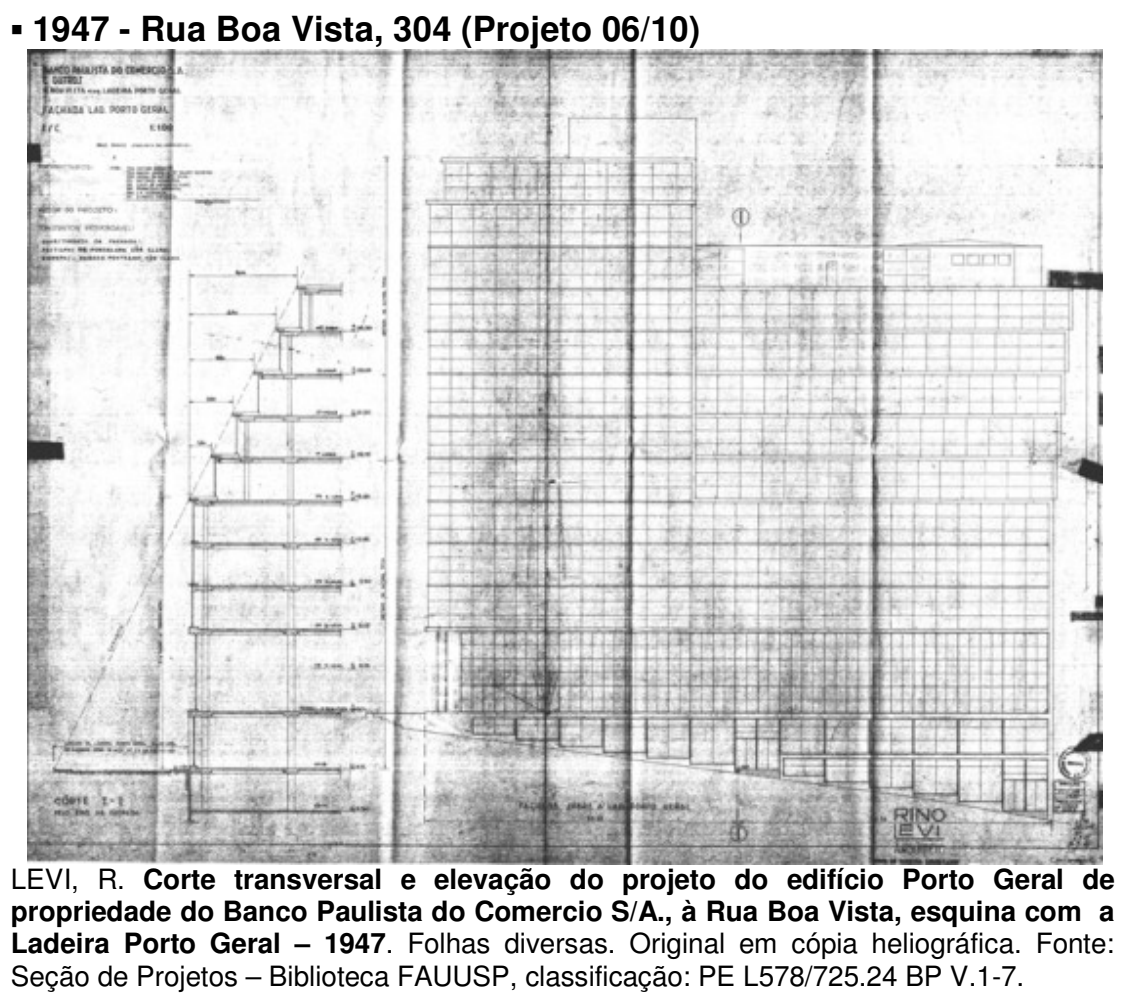


A Construtora Warchavchik-Newmann projetou em 1953 o edifício La Royale, com 95 salas comerciais dispostas em 11 pavimentos. Seu recuo frontal, conforme verificado na imagem abaixo, ocorre a partir do $8^{\circ}$ pavimento de acordo com 0 Decreto-Lei no 92 de 1941, em função da largura da via e de uma linha imaginária que liga o lado aposto da via ao ponto limite de altura estabelecida sem recuo no alinhamento frontal. Para iluminação e ventilação natural foi criado um grande poço interno ao lote, com área próxima ao mínimo estabelecido pela Lei no 2.332 de 1920, conforme se verifica no projeto reproduzido a seguir, em escala reduzida. $O$ coeficiente de aproveitamento desta obra supera 6 vezes a área do lote e sua taxa de ocupação pode ser entendida como $100 \%$, pois ao nível do térreo a área de ventilação interna é coberta e tem uso. Esta edificação também não apresenta corredor lateral de ventilação e insolação, previsto pelo Ato nำ 900, de 1916.

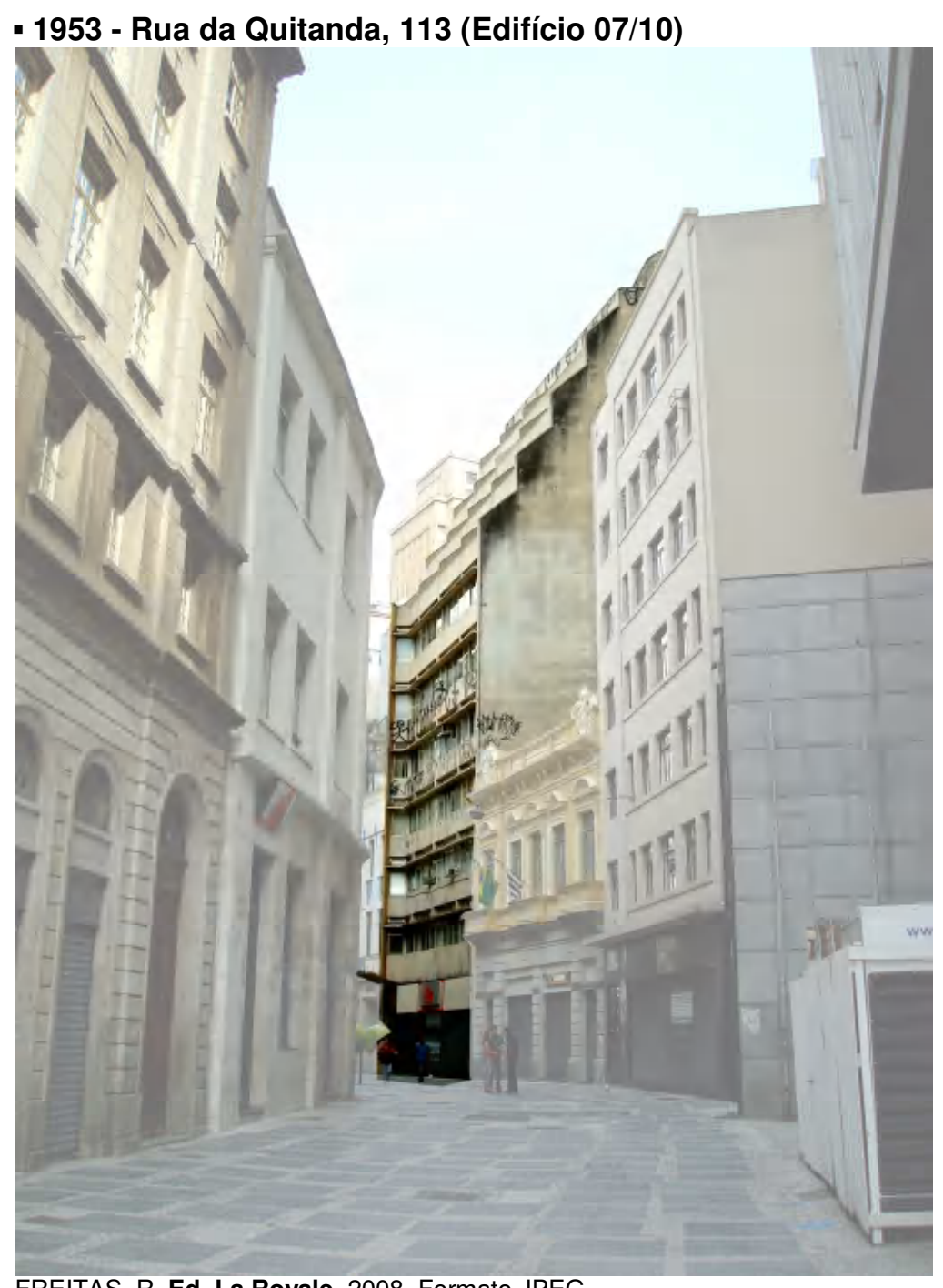


- 1953 - Rua da Quitanda, 113 (Projeto 07/10)

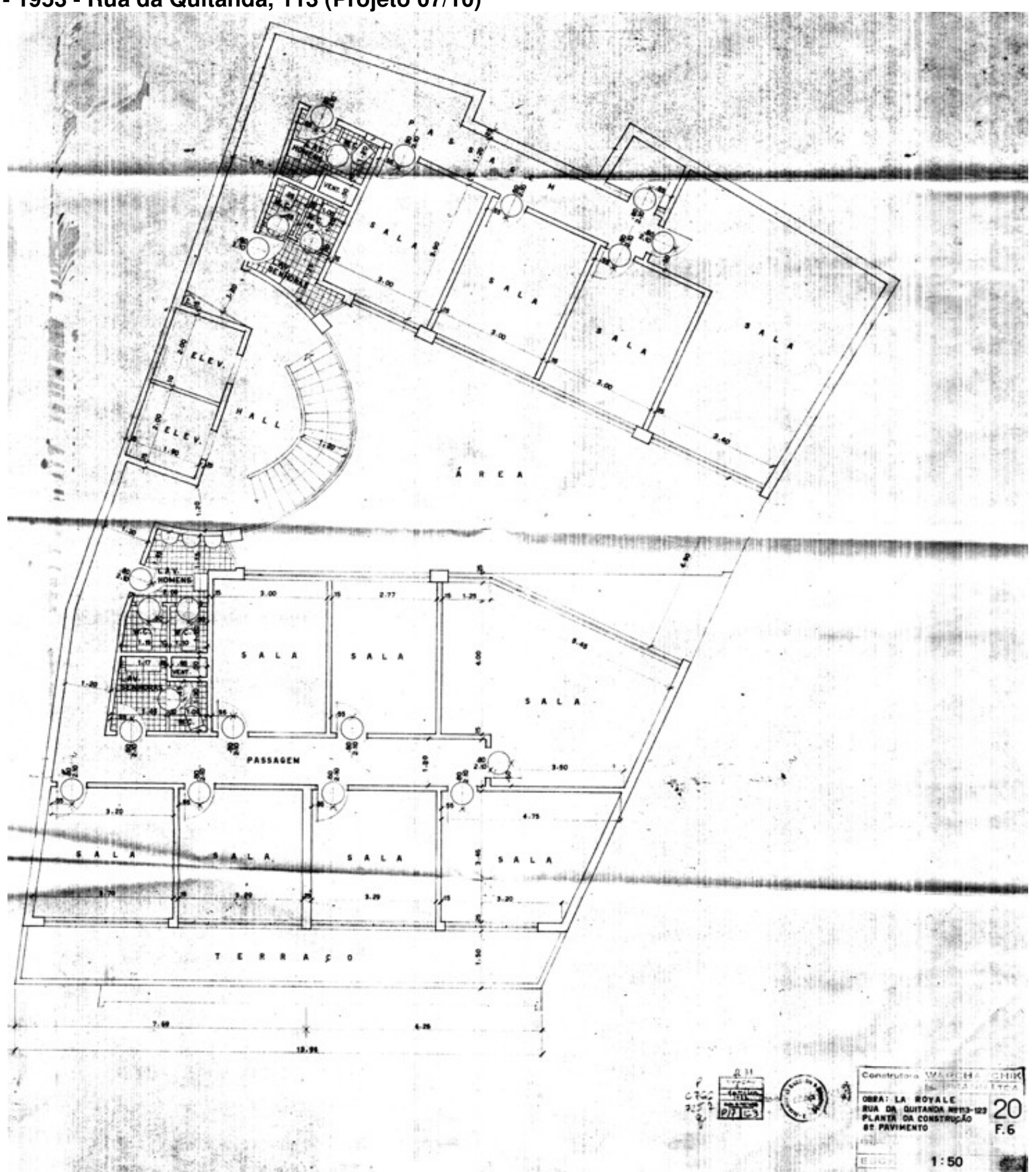

Construtora Warchavchik-Newmann Ltda. Planta $8^{\circ}$ pavimento do projeto do Edifício La Royale de propriedade de Emmanuel Bloch Joias à Rua da Quitanda, no 113 - 1953. Folhas diversas. Original em cópia heliográfica. Fonte: Seção de Projetos - Biblioteca FAUUSP, classificação: PE C766/725.2 Q V.1-2.

O corte da próxima página evidencia que até a metade do século XX não se exigiam e não se projetavam vagas para automóveis nos edifícios do "centro" de São Paulo. Nota-se que a este tempo passavam-se mais de quinze anos da liberação do "motivo arquitetônico" das obras, expresso em lei, quanto às fachadas frontais, cujas janelas já não seguiam as dimensões estabelecidas pelo padrão municipal do início do século XX. No entanto, enquanto as fachadas frontais, de acordo com a 
legislação deveriam passar por uma comissão estética - apesar de liberadas do "estilo" arquitetônico - às fachadas laterais restavam as empenas cegas, resultantes da aplicação dos critérios legais de alinhamento do edifício aos limites laterais da propriedade.

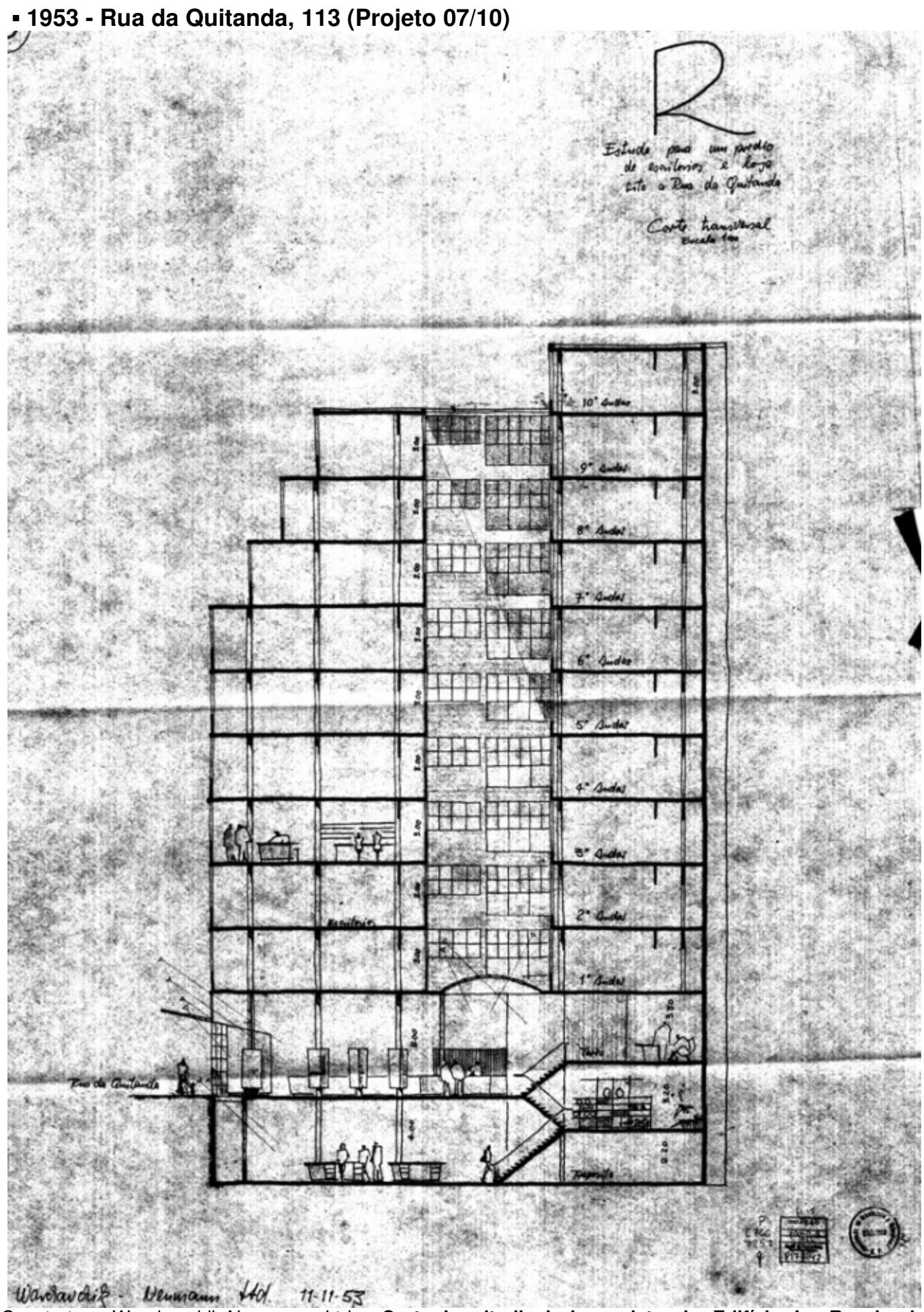

Construtora Warchavchik-Newmann Ltda. Corte longitudinal do projeto do Edifício La Royale de propriedade de Emmanuel Bloch Joias à Rua da Quitanda, no 113 - 1953. Folhas diversas. Original em cópia heliográfica. Fonte: Seção de Projetos - Biblioteca FAUUSP, classificação: PE C766/725.2 Q V.1-2.

Este edifício retratado na imagem abaixo, situado em uma zona do tipo Z5 - 
construído após a criação da Lei n 8.001 de 1973 - apresenta-se de acordo com o critério de recuos mínimos laterais e de fundos de 3 metros. Com projeto de Ruy Ohtake, no terreno de $930 \mathrm{~m}^{2}$ foram construídos $5620 \mathrm{~m}^{2}$, resultado do coeficiente de aproveitamento 3,5 (3255 $\mathrm{m}^{2}$ de área construída computável), com $2365 \mathrm{~m}^{2}$ de área não computável, que inclui os subsolos para estacionamento de automóveis. Dentre as leis pesquisadas neste trabalho, verificou-se apenas em 1957 a citação e regulamentação de estacionamentos em edifícios do "centro", que de acordo com a Lei no 5261 poderiam chegar a 3 vezes a área do terreno, além da área computável máxima naquele período. Este critério para áreas de estacionamento manteve-se até 1972, quando a Lei no 7805 definiu o mínimo de 1 vaga de automóvel a cada 50 $\mathrm{m}^{2}$ de área computável construída.

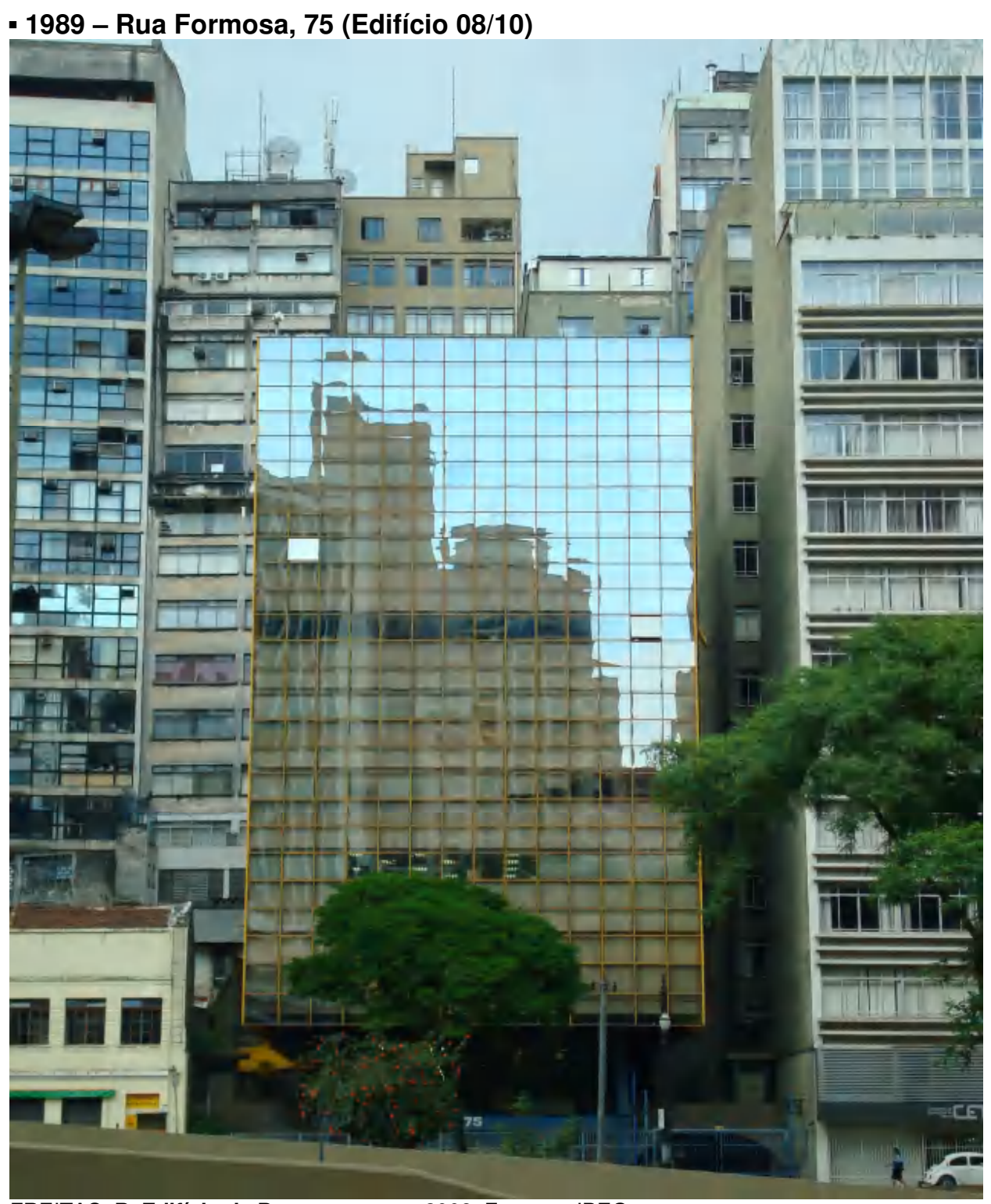

FREITAS, R. Edifício de Paranapanema, 2008. Formato JPEG 
- 1989 - Rua Formosa, 75 (Projeto 08/10)

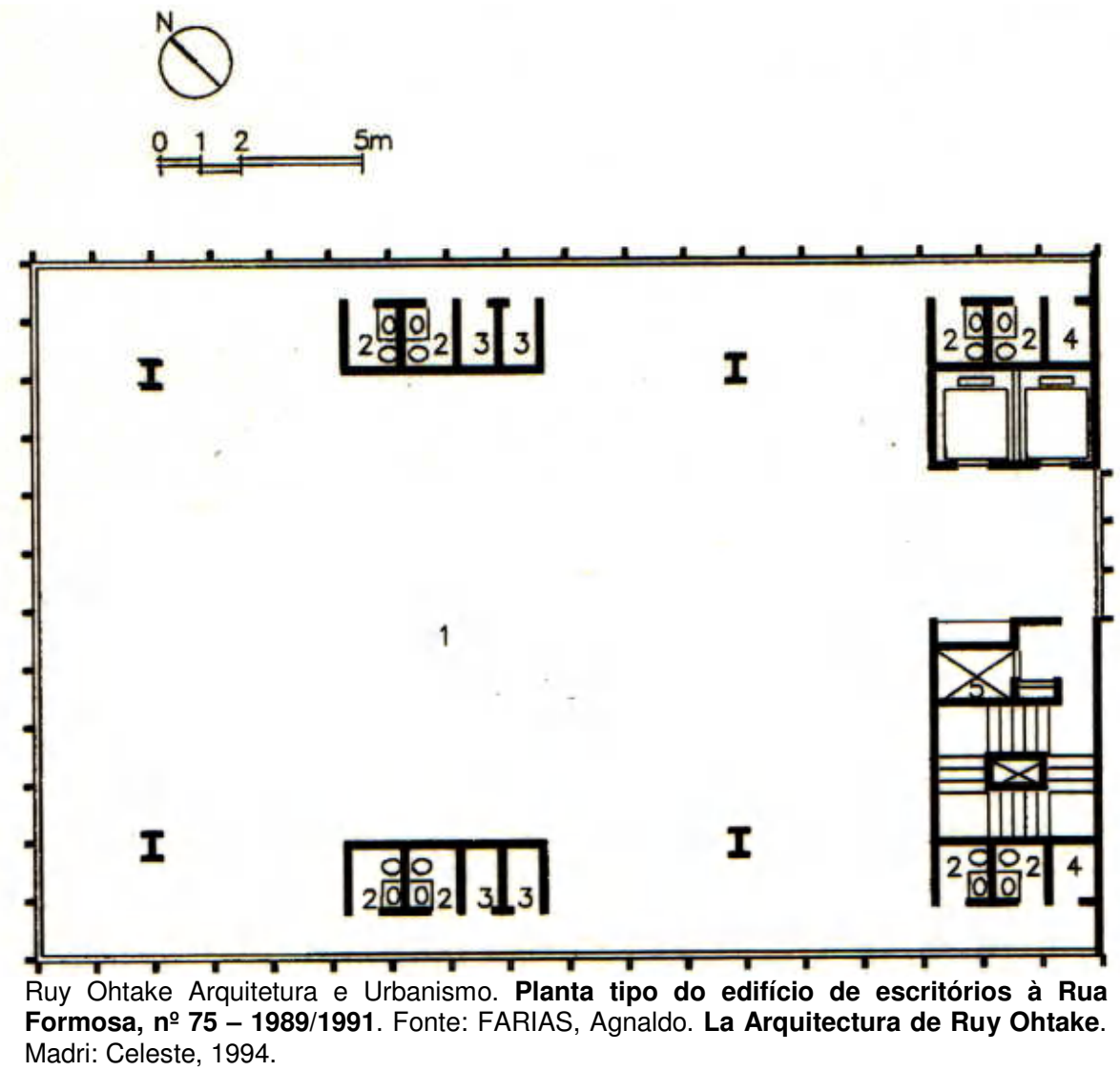

Neste terreno, com testada de aproximadamente 23 metros de comprimento linear, verifica-se que a taxa de ocupação máxima permitida de $80 \%$ não foi atingida, chegando-se a uma projeção de aproximadamente 55\% da propriedade, adequando-se ao critério de ocupação da Lei nº 8.001 de 1973.

Com aproximadamente 35 metros de profundidade, este lote tem grande dimensão se comparado aos pequenos lotes criados no século XIX, predominantes no "centro" de São Paulo. Percebe-se que o resultado final da implantação desta obra reflete certa coerência entre a estrutura física (o lote) e a estrutura não física (a legislação). Como neste trabalho entende-se que a edificação é um fluxo urbano orientado pelas estruturas que o precedem, pode-se dizer que há coerência entre este fluxo e a realidade urbana existente quando de sua construção, isto é, de acordo com os critérios urbanísticos vigentes hoje, há coerência entre as escalas do edifício e do lote. Na próxima página expõe-se a planta do nível térreo, que abre-se para a Rua Formosa, na qual se vê a projeção do pavimento tipo e as áreas ajardinadas indicadas com o número de legenda 3. 
- 1989 - Rua Formosa, 75 (Projeto 08/10)

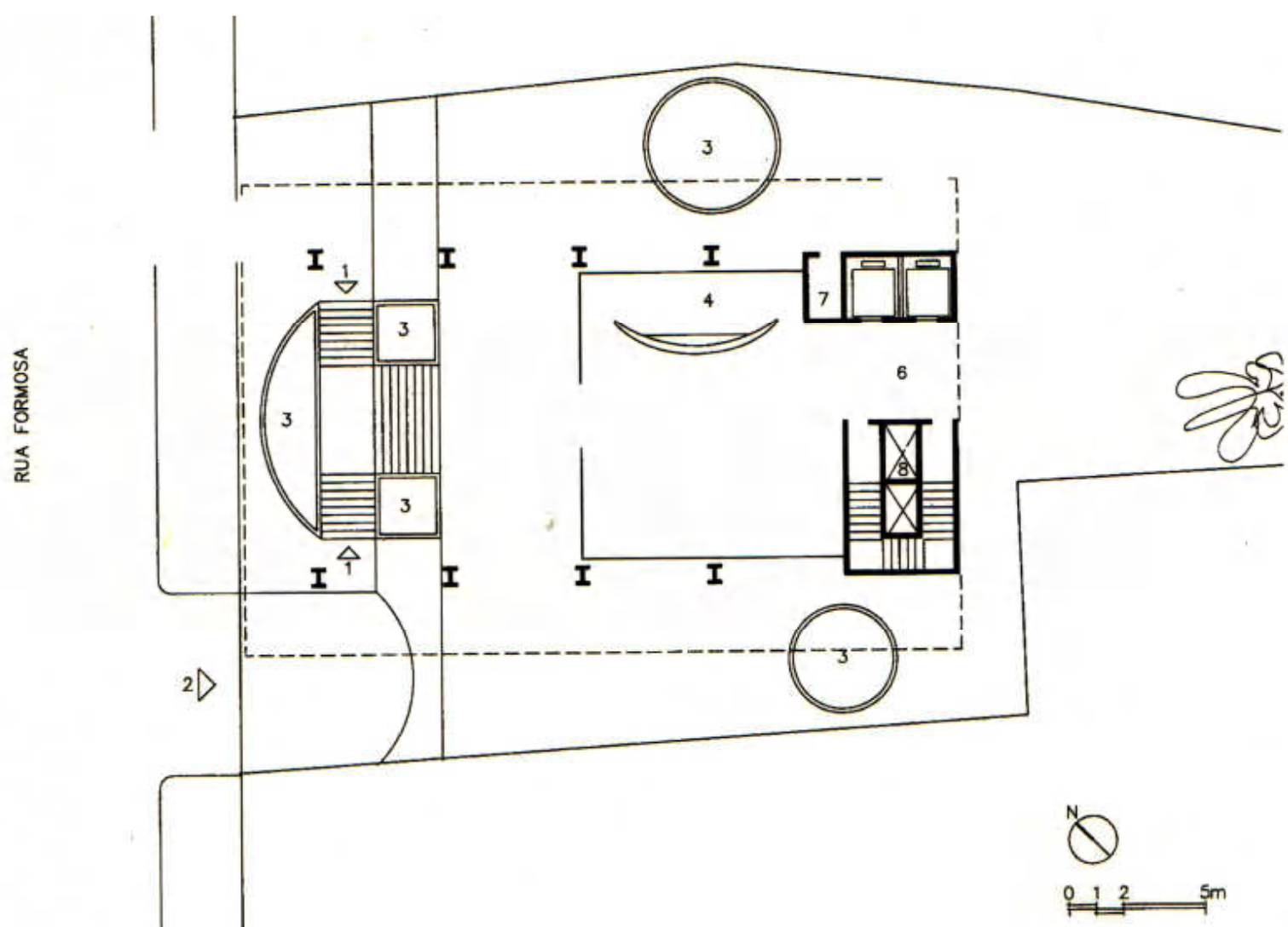

Ruy Ohtake Arquitetura e Urbanismo. Planta do térreo do edifício de escritórios à Rua Formosa, no 75 - 1989/1991. Fonte: FARIAS, Agnaldo. La Arquitectura de Ruy Ohtake. Madri: Celeste, 1994.

A fotografia da próxima página retrata o edifício projetado por Roberto Candusso para a Construtora Setin, à Rua Araújo no 141, resultado da utilização da Lei no 12.349 de 1997 - Operação Urbana Centro. Este edifício, aprovado pela prefeitura em 1999, foi implantado em um lote de aproximadamente $2010 \mathrm{~m}^{2}$. De acordo com esta lei, o remembramento de lotes - com área resultante maior que $2000 \mathrm{~m}^{2}$ permitiria a utilização de coeficiente de aproveitamento 9 nos 36 primeiros meses subseqüentes à aprovação da lei. No entanto, para esta edificação, por motivo desconhecido foi utilizado coeficiente de aproveitamento 4, o que já era possibilitado pela Lei no 8006 de 1974. A fachada do conjunto edificado anterior foi restaurada e mantida. Os recuos laterais não obedecem ao mínimo estabelecido para Z5 se consideradas as escadas laterais de rota de emergência. Deste modo, entende-se que a desregulamentação urbana permitida pela Operação Urbana Centro permitiu uma análise em particular deste projeto, considerando-se o recuo a partir do volume definido pelo pavimento tipo, mas não pelas escadas de segurança laterais, conforme verifica-se nas plantas expostas a seguir. 
- 1999 - Rua Araújo, 141 (Edifício 09/10)

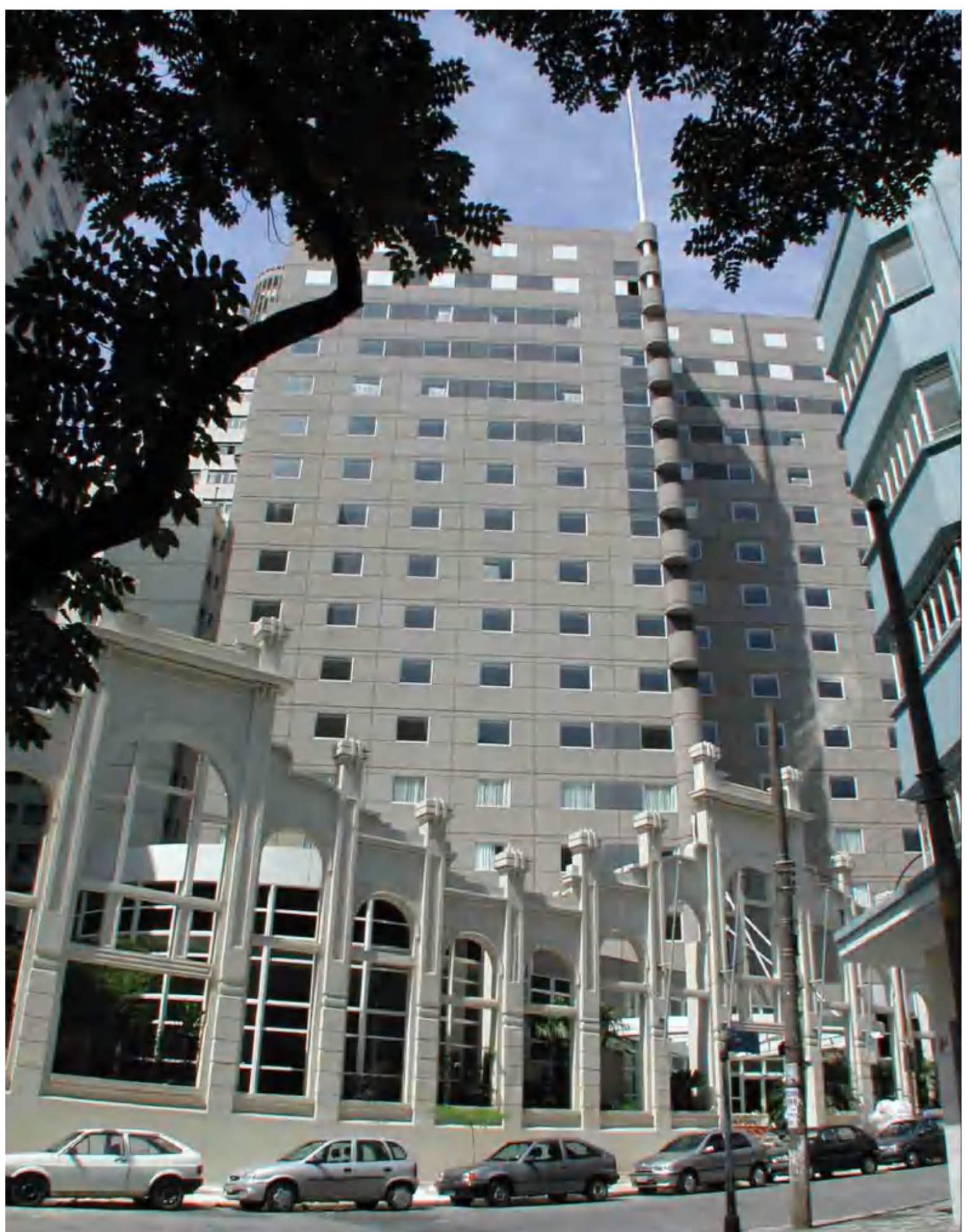

Candusso, R. [sem título], 2003. Formato JPEG 
- 1999 - Rua Araújo, 141(Projeto 09/10)

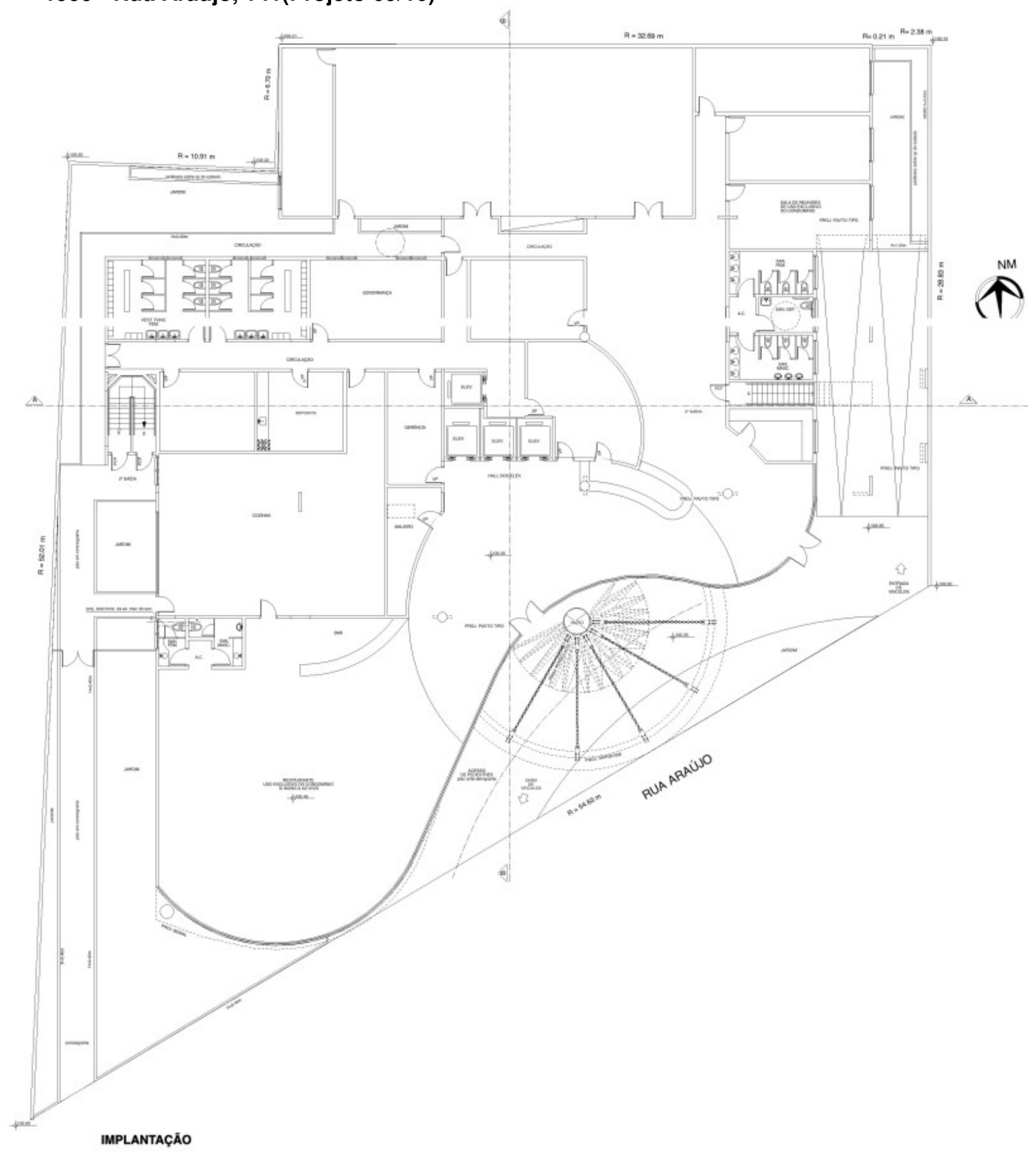

Candusso Arquitetos. Planta do térreo do hotel projetado para a Construtora Setin à Rua Araújo, no 141 - 1999 Fonte: Arquivo Candusso Arquitetos.

Verifica-se na planta a seguir que a faixa de aeração (faixa $A$ ) não foi aplicada às fachadas laterais, pois estas não têm abertura. Porém, como resultado de sua aplicação, verifica-se um grande recuo frontal, bem como de fundos, de acordo com a Lei n 11228, de 1992, o Novo Código de Obras e Edificações, ainda em vigor nos dias de hoje, 2008. 
- 1999 - Rua Araújo, 141(Projeto 09/10)

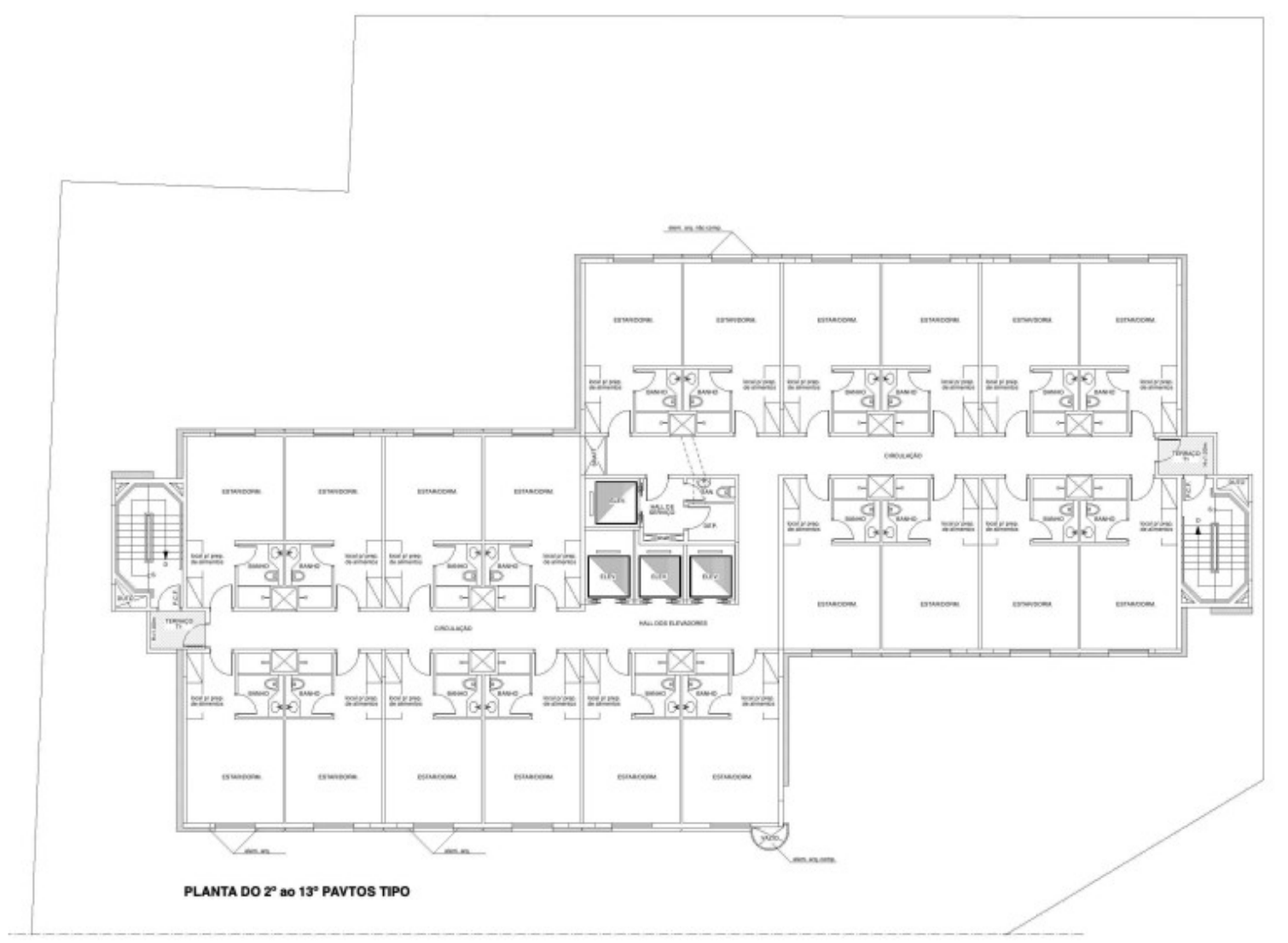

Candusso Arquitetos. Planta do pavimento tipo do hotel projetado para a Construtora Setin à Rua Araújo, no 141 1999 Fonte: Arquivo Candusso Arquitetos.

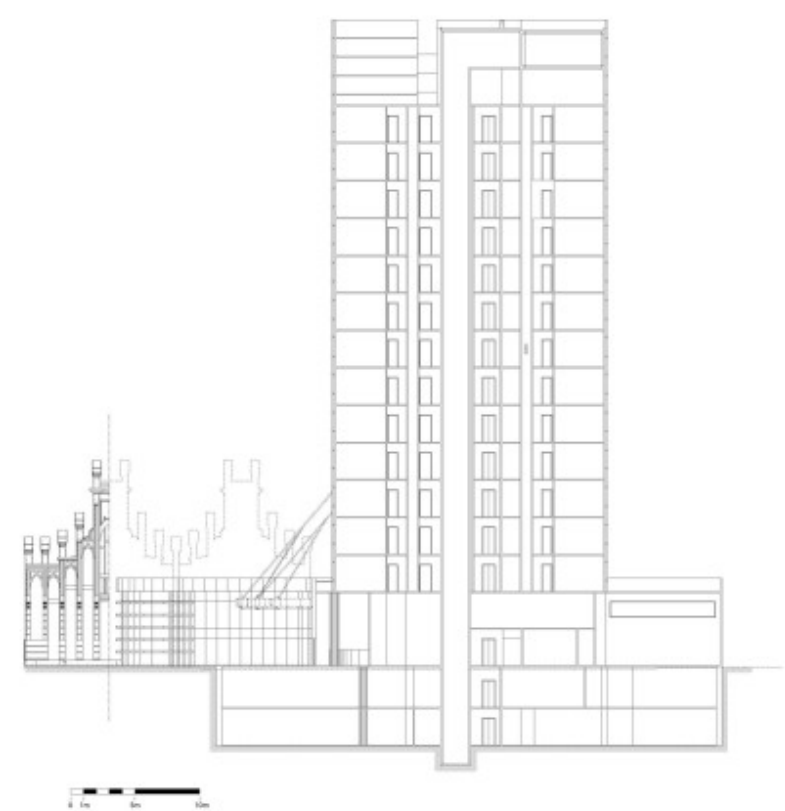

Candusso Arquitetos. Corte, transversal à via, do hotel projetado para a Construtora Setin à Rua Araújo, no 141 - 1999 Fonte: Arquivo Candusso Arquitetos. 
Apesar de construído fora do período estudado nesta pesquisa, seu projeto foi desenvolvido e segue as regras legais que vigoravam em 2001. O edifício da Fundação Carlos Chagas retratado abaixo, com projeto de Ruy Ohtake (2001), foi aprovado em 2003, antes de entrar em vigor o Novo Zoneamento de São Paulo, a Lei $n^{\circ} 13885$ de 2004. Desta maneira, foi regulamentado pela Lei $n^{0} 12.349$ de 1997 - Operação Urbana Centro - e por isso tem lugar neste conjunto de projetos e edifícios expostos como exemplos de aplicação da legislação urbana do século XX. Em 2005 foi aprovado um projeto revisado, como modificativo, sem acréscimo de área, portanto, utilizando-se o zoneamento vigente no século XX, a partir de 1972.

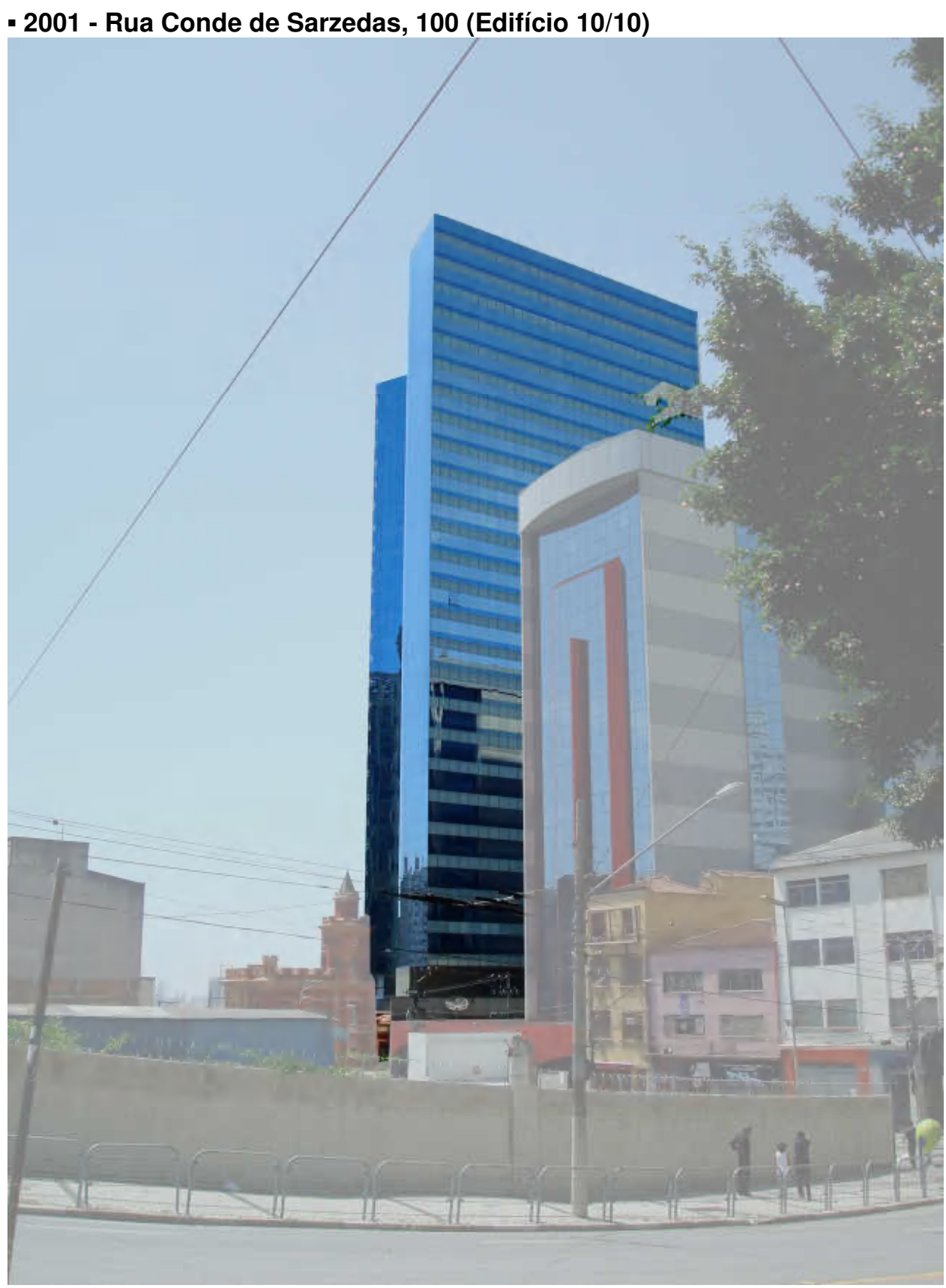


Sua construção, finalizada em 2006, reflete a desregulamentação do zoneamento vigente por ter se adequado à Operação Urbana Centro, que permitiu a alteração do coeficiente de aproveitamento 3,5 da Z5 - onde está inserido - para 6 vezes a área do terreno. Isto foi possível em função do remembramento dos lotes que contêm os três edifícios visualizados na foto acima (o Castelinho, o Conde de Sarzedas e o edifício à sua esquerda, com fachada também em pele de vidro). Desta forma, considerou-se como um único empreendimento a implantação das três obras no lote resultante do agrupamento de todas as matrículas que os contêm.

- 2001 - Rua Conde de Sarzedas, 100 (Projeto 10/10)

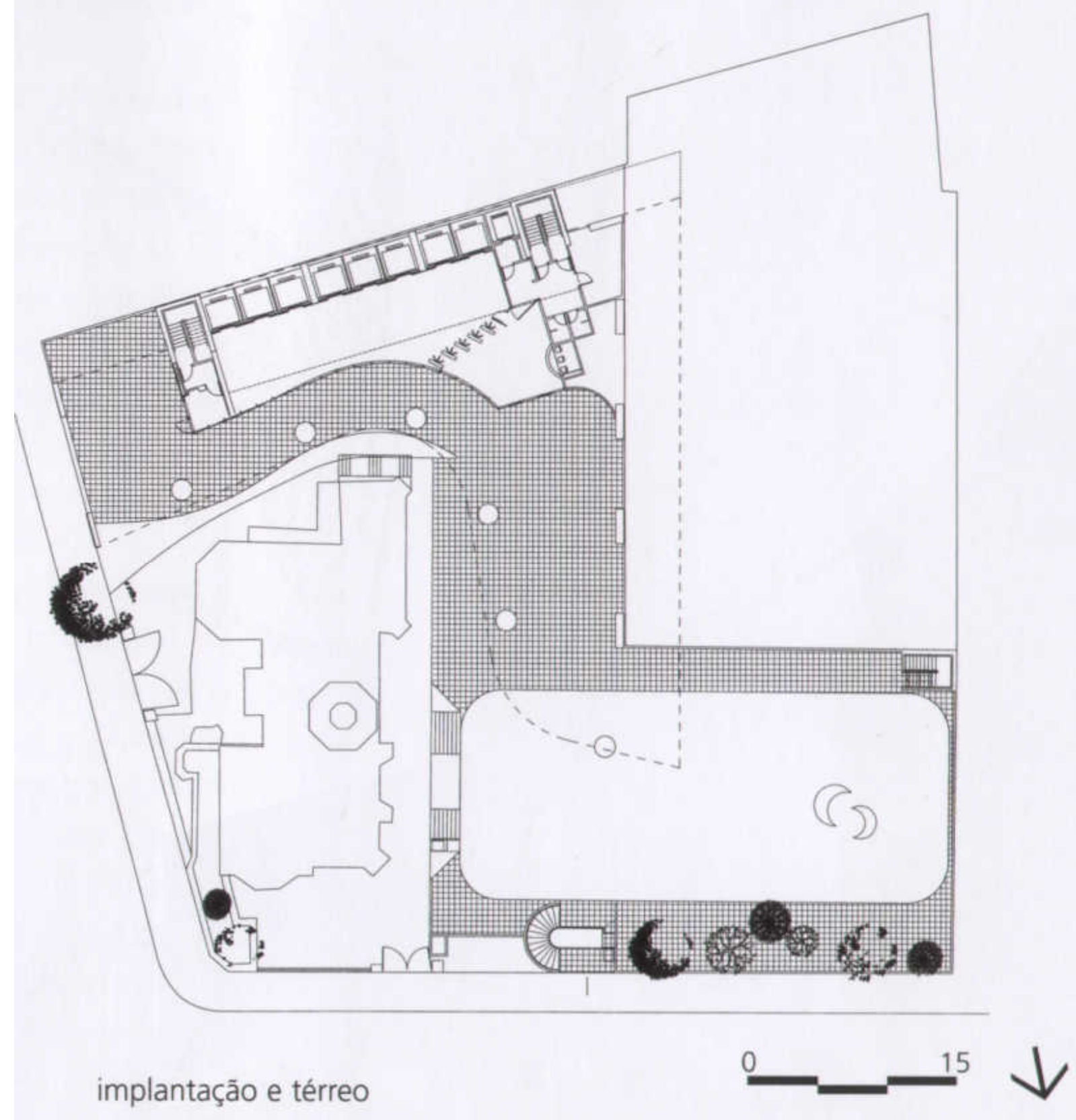

Ruy Ohtake Arquitetura e Urbanismo. Planta do térreo do edifício de escritórios de propriedade da Fundação Carlos Chagas à Rua Conde de Sarzedas, no 100 - 2001/2006. Fonte: Revista AU. São Paulo, PINI. Publicação de dezembro/2006. 
Nota-se à esquerda da planta acima que não há recuo desta edificação junto ao alinhamento da Rua Dr. Tomas de Lima, perpendicular à Rua Conde de Sarzedas. Entende-se que se aplicou a regra do zoneamento que permite edificar-se no alinhamento frontal quando mais de $50 \%$ da quadra encontra-se edificada neste alinhamento.

Sua taxa de ocupação esta por volta de $50 \%$ a área do lote, abaixo do máximo de $80 \%$ permitido para $Z 5$, provavelmente em função das outras edificações desta propriedade, que somadas devem atingir $80 \%$ de projeção. O pequeno recuo entre este edifício e os outros dois (o Castelinho e o edifício à sua esquerda com pele de vidro) respeita apenas a "faixa A" definida pela Lei oㅜ 11228, de 1992, pois estão todos no mesmo lote, não se aplicando critérios de recuos laterais e de fundos entre os três edifícios. Seus subsolos para estacionamento resultam da proporção de 1 vaga a cada $50 \mathrm{~m}^{2}$ de área construída computável, seguindo critério da Secretaria Municipal de Transportes, em análise específica deste projeto.

- 2001 - Rua Conde de Sarzedas, 100 (Projeto 10/10)

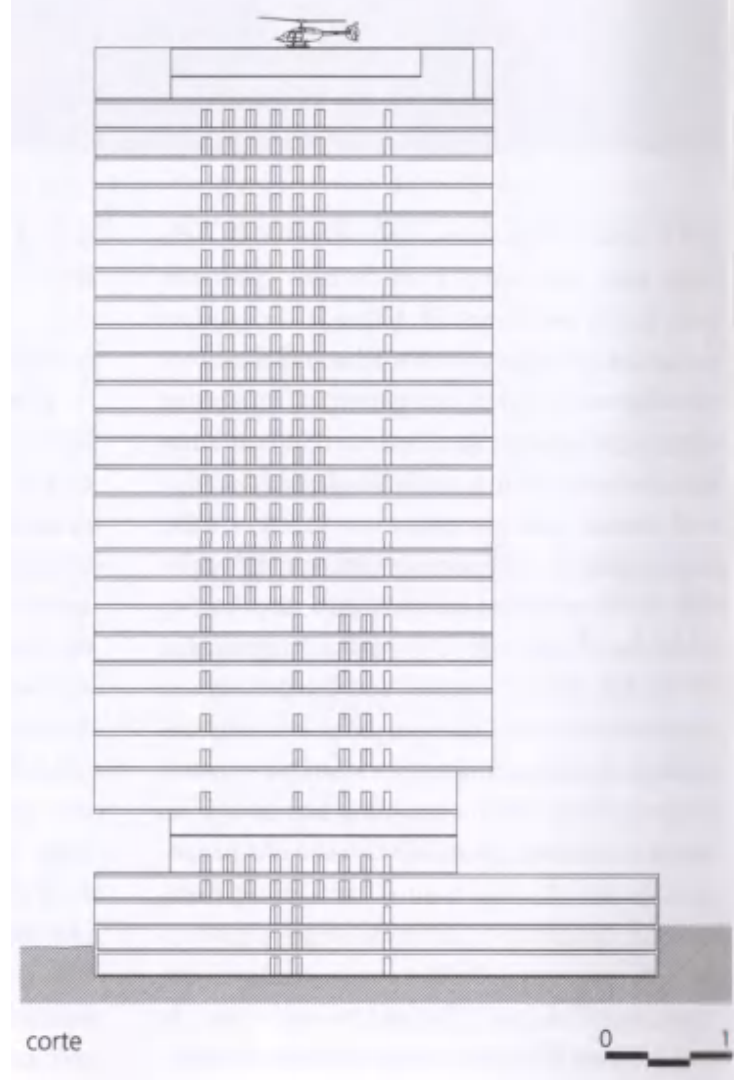

Ruy Ohtake Arquitetura e Urbanismo. Corte do edifício de escritórios de propriedade da Fundação Carlos Chagas à Rua Conde de Sarzedas, no $100-2001 / 2006$. Fonte: Revista AU. São Paulo, PINI. Publicação de dezembro/2006. 


\section{ANEXO 2 - CATEGORIAS DE USO E OCUPAÇÃO DO SOLO}

Lei nํ 7.805/72; Lei no 8.001/73; Decreto n 11.106/74 - vigência até 2004:

Residencial:

$\mathrm{R} 1$ - residência unifamiliar

R2 - residência multifamiliar:

.R2.01 - unidades residenciais agrupadas horizontalmente

.R2.02 - unidades residenciais agrupadas verticalmente com acesso comum

.R2.03 - unidades residenciais agrupadas superpostas com acesso independente R3 - conjunto residencial:

.R3.01 - até 400 unidades ou terreno até 20.000 m2

.R3.02 - acima dos limites de R3.01

.R3.03 - vilas

HIS - habitação de interesse social

Comercial:

C1 - comércio varejista de âmbito local (até 250 m2):

.C1.1 - comércio de alimentação

.C1.2 - comércio eventual

C2 - comércio varejista diversificado :

.C2.1 - comércio de consumo excepcional

.C2.2 - comércio de consumo no local ou associado a diversões

.C2.3 - comércio de centros e intermediários

.C2.4 - comércio de centro sub-regional

.C2.5 - comércio especializado (para profissionais)

.C2.6 - comércio de material de grande porte

.C2.7 - comércio de depósitos de material em geral ( até $1.000 \mathrm{~m} 2$ )

.C2.8 - comércio de produtos perigosos

.C2.9 - comércio de distribuição de materiais de pequeno porte

C3 - comércio atacadista :

.C3.1 - comércio de produtos alimentícios

.C3.2 - comércio de materiais de grande porte 
.C3.3 - comércio de produtos perigosos

.C3.4 - comércio de produtos agropecuários ou extrativos

.C3.5 - comércio diversificado

Serviços:

S1 - serviços de âmbito local (até $250 \mathrm{~m} 2$ );

.S1.1 - serviços profissionais e de negócios

.S1.2 - serviços pessoais e domiciliares

.S1.3 - serviços de educação

.S1.4 - serviços sócio-culturais

.S1.5 - serviços de hospedagem

.S1.6 - serviços de diversões

.S1.7 - serviços de estúdios de oficinas

S2 - serviços diversificados :

.S2.1 - serviços de escritórios de negócios

.S2.2 - serviços pessoais e de saúde

.S2.3 - serviços de educação

.S2.4 - serviços sócio-culturais

.S2.5 - serviços de hospedagem

.S2.6 - serviços de diversões

.S2.7 - serviços de estúdios, laboratórios de oficinas técnicas

.S2.8 - serviços de oficinas

.S2.9 - serviços de guarda, distribuição e arrendamento de bens móveis S3 - serviços especiais :

.S3.1 - garagens para empresas de transportes

.S3.2 - serviços de depósitos de armazenagem

Institucional:

E1 - instituições de âmbito local (até 250 m2)

.E1.1 - educação

.E1.2 - lazer e cultura

.E1.3 - saúde

.E1.4 - assistência social

.E1.5 - culto 
.E1.6 - comunicação

E2 - instituições diversificadas:

.E2.1 - educação

.E2.2 - lazer e cultura

.E2.3 - saúde

.E2.4 - assistência social

.E2.5 - culto

.E2.6 - administração e serviço público

.E2.7 - transporte e comunicação

E3 - instituições especiais:

.E3.1 - educação

.E3.2 - o lazer e cultura

.E3.3 - saúde

.E3.4 - assistência social

.E3.5 - culto

.E3.6 - administração e serviço público

.E3.7 - transporte e comunicação

E4 - usos especiais

Industrial:

11 - indústrias não incômodas de não poluentes (até 500 m2)

12 - indústrias diversificadas de não poluentes

13 - indústrias especiais 


\section{ANEXO 3 - OS PREFEITOS DE SÃO PAULO}

1. $07 / 01 / 1899$ a $15 / 01 / 1911$ - Antonio da Silva Prado

2. 16/01/1911 a 14/01/1914 - Raymundo da Silva Duprat

3. 15/01/1914 a 15/08/1919 - Washington Luís Pereira de Souza

4. 16/08/1919 a 15/01/1920 - Álvaro Gomes da Rocha Azevedo

5. 16/01/1920 a 15/01/1926 - Firmiano Morais Pinto

6. 16/01/1926 a 23/10/1930 - José Pires do Rio

7. $24 / 10 / 1930$ a 05/12/1930 - Joaquim José Cardoso de Mello Neto

8. 06/12/1930 a 25/07/1931 - Luiz Ignácio de Anhaia Mello

9. 26/07/1931 a 13/11/1931 - Francisco Machado de Campos

10.14/11/1931 a 04/12/1931 - Luiz Ignácio de Anhaia Mello

11.05/12/1931 a 23/05/1932 - Henrique Jorge Guedes

12.24/05/1932 a 02/10/1932 - Goffredo da Silva Telles

13.03/10/1932 a 28/12/1932 - Arthur Saboya

14.29/12/1932 a 01/04/1933 - Theodoro Augusto Ramos

15.02/04/1933 a 22/05/1933 - Arthur Saboya

16.23/05/1933 a 30/07/1933 - Oswaldo Gomes da Costa

17.31/07/1933 a 21/08/1933 - Carlos dos Santos Gomes

18.22/08/1933 a 06/09/1934 - Antonio Carlos Assumpção

19.07/09/1934 a 31/01/1938 - Fábio da Silva Prado

20.01/02/1938 a 15/02/1938 - Paulo Barbosa de Campos Filho

21.16/02/1938 a 30/04/1938 - Fábio da Silva Prado

22.01/05/1938 a 10/11/1945 - Francisco Prestes Maia

23.11/11/1945 a 14/03/1947 - Abrahão Ribeiro

24.15/03/1947 a 28/08/1947 - Christiano Stockler das Neves

25.29/08/1947 a 25/08/1948 - Paulo Lauro

26.26/08/1948 a 03/01/1949 - Milton Improta

27.14/01/1949 a 27/02/1950 - Asdrúbal Euritysses da Cunha

28.28/02/1950 a 31/01/1951 - Lineu Prestes

29.01/02/1951 a 07/04/1953 - Armando de Arruda Pereira

30.08/04/1953 a 06/07/1954 - Jânio da Silva Quadros

31.07/07/1954 a 17/01/1955 - José Porfírio da Paz 
32. 18/01/1955 a 05/02/1955 - Jânio da Silva Quadros

33.06/02/1955 a 01/05/1955 - William Salem

34.02/07/1955 a 10/04/1956 - Juvenal Lino de Mattos

35.11/04/1956 a 07/04/1957 - Wladimir de Toledo Pizza

36.08/04/1957 a 09/01/1958 - Adhemar Pereira de Barros

37.10/01/1958 a 06/02/1958 - Cantídio Nogueira Sampaio

38.07/02/1958 a 08/02/1961 - Adhemar Pereira de Barros

39.09/02/1961 a 28/02/1961 - Manoel de Figueiredo Ferraz

40.01/03/1961 a 07/04/1961 - Adhemar Pereira de Barros

41.08/04/1961 a 07/04/1965 - Francisco Prestes Maia

42.08/04/1965 a 07/04/1969 - José Vicente Faria Lima

43.08/04/1969 a 07/04/1971 - Paulo Salim Maluf

44.08/04/1971 a 21/08/1973 - José Carlos de Figueiredo Ferraz

45.22/08/1973 a 27/08/1973 - João Brasil Vita

46.28/08/1973 a 16/08/1975 - Miguel Colasuono

47.17/08/1975 a 11/07/1979 - Olavo Egídio Setúbal

48.12/07/1979 a 14/05/1982 - Reynaldo Emygdio de Barros

49.15/05/1982 a 14/03/1983 - Antonio Salim Curiati

50.15/03/1983 a 10/05/1983 - Francisco Altino Lima

51.11/05/1983 a 31/12/1985 - Mario Covas

52.01/01/1986 a 31/12/1988 - Jânio da Silva Quadros

53.01/01/1989 a 31/12/1992 - Luiza Erundina de Souza

$54.01 / 01 / 1993$ a 31/12/1996 - Paulo Salim Maluf

55.01/01/1997 a 25/05/2000 - Celso Pitta 